\title{
Clinton and Bush administrations' nuclear non-proliferation *policies on North Korea: Challenges and implications of systemic and domestic constraints
}

\author{
Gunsik Kim \\ West Virginia University
}

Follow this and additional works at: https://researchrepository.wvu.edu/etd

\section{Recommended Citation}

Kim, Gunsik, "Clinton and Bush administrations' nuclear non-proliferation *policies on North Korea: Challenges and implications of systemic and domestic constraints" (2005). Graduate Theses,

Dissertations, and Problem Reports. 4162.

https://researchrepository.wvu.edu/etd/4162

This Dissertation is protected by copyright and/or related rights. It has been brought to you by the The Research Repository @ WVU with permission from the rights-holder(s). You are free to use this Dissertation in any way that is permitted by the copyright and related rights legislation that applies to your use. For other uses you must obtain permission from the rights-holder(s) directly, unless additional rights are indicated by a Creative Commons license in the record and/ or on the work itself. This Dissertation has been accepted for inclusion in WVU Graduate Theses, Dissertations, and Problem Reports collection by an authorized administrator of The Research Repository @ WVU.

For more information, please contact researchrepository@mail.wvu.edu. 


\title{
Clinton and Bush Administrations' Nuclear Non-proliferation Policies \\ On North Korea: Challenges and Implications \\ Of Systemic and Domestic Constraints
}

\author{
Gunsik Kim \\ A Dissertation submitted to the Eberly College of Arts \& Sciences \\ at West Virginia University \\ in partial fulfillment of the requirements \\ for the degree of \\ Doctor of Philosophy \\ in \\ Political Science
}

\begin{abstract}
Approved by
Joe D. Hagan, Ph.D., Committee Chair

Hong N. Kim, Ph.D., Committee Co-Chair

R. Scott Crichlow, Ph.D.

Jack Hammersmith, Ph.D.

Jeffrey Worsham, Ph.D.
\end{abstract}

Political Science

Morgantown, West Virginia

2005

Keywords: Non-Proliferation Policy, Clinton Administration, Bush Administration, North Korea, US Foreign Policy, Korean Conflict

Copyright 2005 Gunsik Kim 


\section{Abstract \\ Clinton and Bush Administrations’ Nuclear Non-proliferation Policies \\ On North Korea: Challenges and Implications \\ Of Systemic and Domestic Constraints}

\section{Gunsik Kim}

This study compared and evaluated the conduct of US policies towards North Korea in order to address the North Korean nuclear threat under the Clinton (1993-2000) and the Bush (2001-2004) administrations. The capabilities of the two administrations to carry out their preferred policies toward the global threat were evaluated in view of the systemic and domestic constraints that they faced. Domestic constraints identified were the US Congress, American political culture and public opinion and bureaucratic problems. Systemic constraints were the lack of coordination and differences in policy frameworks of South Korea, Japan, China and Russia, and the difficulty of dealing with the Kim regime. These systemic and domestic constraints were deemed by this study as the primary factors in their inclination towards the middle ground in dealing with North Korea hence, becoming similar.

Three major areas were examined: (1) Clinton and Bush administrations’ original policy position towards North Korea in terms of the use of bilateralism and multilateralism, carrots and sticks, and the inclusion/exclusion of the international regimes; (2) identification of the systemic and domestic constraints that affected the full implementation of the policies as originally proposed by the Clinton and Bush administrations; and (3) the extent to which Clinton and Bush had to adjust policies towards North Korea in terms of the use of bilateralism and multilateralism, carrots and sticks, and the inclusion/exclusion of the international regimes at the end of their term.

Using a structured focused comparison, this study predicts that, due to the domestic and systemic factors, the Bush administration is inclined to use the carrot strategies, and the exclusion of the international regime as employed in the Clinton administration, but is likely to employ bi-multilateral approach. 


\section{Dedication}

This work would have not been possible without the people who had inspired me.

Specially, I would like to dedicate this dissertation to my family and to my country.

To my wife, Soon-hee, whose support has always inspired me.

To my children, Young-woong and Young-won, who have shared my attention with my work and study and whose endless thirst for knowledge and creativity has inspired me.

To my mother, Gil-ja, who has always believed in her son.

To my father, Jong-hoon, whose encouragement is always with me. 


\section{Acknowledgement}

This work has been a product of the patience, wisdom, and collective intelligence of my dissertation committee, Dr. Joe Hagan, Dr. Hong N. Kim, Dr. Jeffrey Worsham, Dr. Scott Crichlow, and Dr. Jack Hammersmith. I would like to extend my sincerest gratitude for their

unselfish sharing of their wisdom and experiences. Their enormous help had inspired and opened my eyes on the direction of this research. I would never have understood the full extent of foreign policy intricacies if not for their patience and guidance. Thank you very much for your faith. Most especially, I would like to thank Dr. Joe Hagan and Dr. Hong N. Kim for their patience and their support all throughout this project.

I thank my wife and my children for serving as my inspiration. To my family who serves as my strength in many points in my life.

To my country and the military service who has believed in my professional growth and who had spared no boundaries in improving the ranks. I salute all of you.

Finally, thanks to the guidance of the Lord who has always kept me inspired. 


\section{Table of Contents}

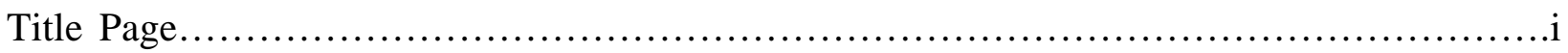

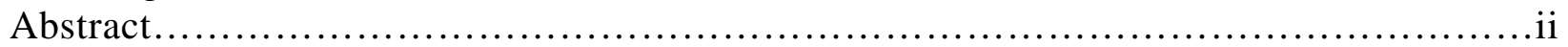

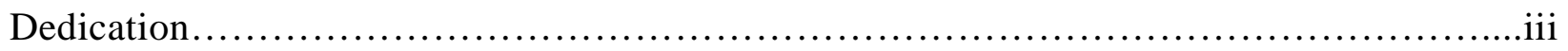

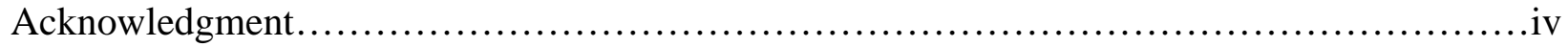

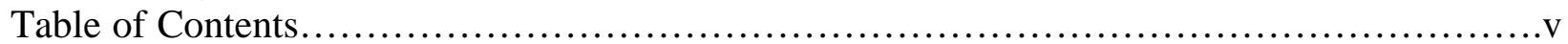

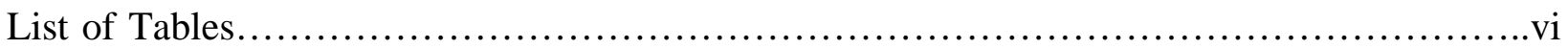

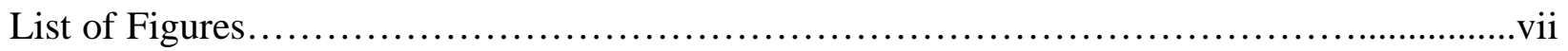

CHAPTER 1: INTRODUCTION AND THEORETICAL FRAMEWORK.................................

The Dimensions of Policy Choice in

U.S. Foreign Policy towards North Korea............................................

Alternative Negotiating Frameworks: Bilateralism versus Multilateralism................4

Coercion versus Incentives in the Instruments of Statecraft.........................6

The Involvement of International Regimes......................................

Explaining U.S. Policy towards North Korea: Systemic and Domestic Constraints.............10

International Systemic Constraints throughout Northeast Asia.........................11

Domestic Political Constraints within the United States.............................12

The Significance of Constraints on US Foreign Policy................................14

Research Questions, Methodology, and Case Selection.................................15

CHAPTER II: THE NORTH KOREAN NUCLEAR CRISIS.....................................21

The North Korean Nuclear Crisis.....................................................22

Motivations for the North Korean Nuclear Program................................28



Overview of US Policies and Politics on North Korea..................................40

US Congress Constraints...................................................43

The American Political Culture and the Public....................................45

American Bureaucratic Politics.....................................................48

International Regime: The NPT and IAEA ..................................49

International Systemic Relations..........................................5 53

Clinton and Bush Administrations' Non-Proliferation Policy..............................55

Clinton Policy and Implementation Strategies...................................57

Bush Policy and Implementation Strategy ....................................60

Towards a Nuclear-Weapon-Free World.......................................63

CHAPTER III: SYSTEMIC AND DOMESTIC CONSTRAINTS

IN CLINTON POLICY ON NORTH KOREA..............................................66

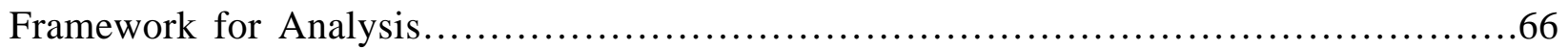

Clinton's Initial Policy on North Korea..............................................68

Clinton's Bilateral Strategy....................................................71

Economic Rewards and the Use of Economic and Diplomatic Means...................72

The International Regime: NPT and IAEA......................................75

The Effects of Domestic and Systemic Constraints on Clinton Policy......................77 


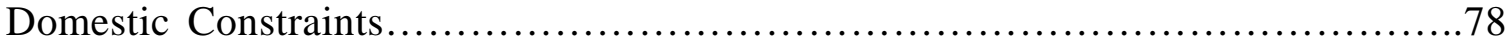

Systemic Constraints on U.S. Foreign Policy....................................91

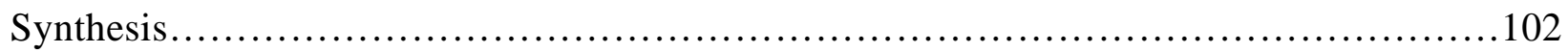

CHAPTER IV: SYSTEMIC AND DOMESTIC CONSTRAINTS

IN BUSH II Policy on North Korea............................................. 107

Bush Administration's Initial Policy on North Korea......................................109

Bush Administration's Policy Shift..............................................114

Bush's Multilateral Strategy: Six-Party Talks..................................116

Rewards, Sanctions and Diplomacy.......................................124

International Regime........................................................126

The Effects of Domestic and Systemic Constraints on Bush Policy.........................128

Domestic Constraints....................................................... 128

International Systemic Constraints.........................................134

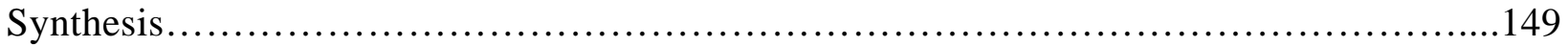

\section{CHAPTER V: STRUCTURED FOCUSED COMPARISON}

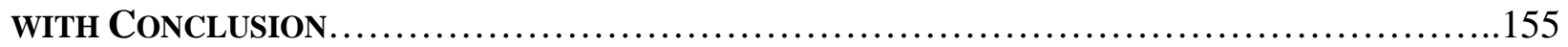

Comparing Initial U.S. Administration Policies....................................... 155

Multilateralism versus Bilateralism.......................................157

Rewards versus Sanctions.................................................160

Containment and Engagement.............................................166

The International Regime: NPT and IAEA ...................................167

Constraints on U.S. Policies towards North Korea.....................................170

The Role of Domestic Constraints.............................................170

International Systemic Constraints..........................................179

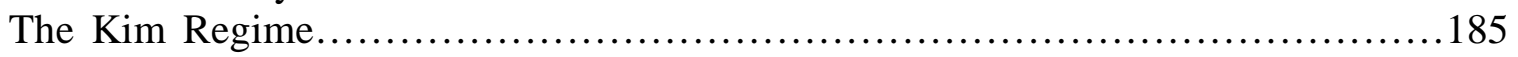

Chapter Conclusion................................................................... 186

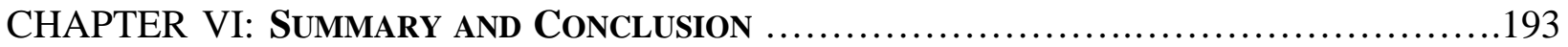

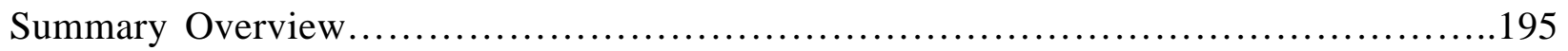

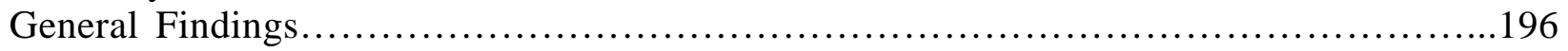

Motivations for the North Korean Nuclear Program................................ 196

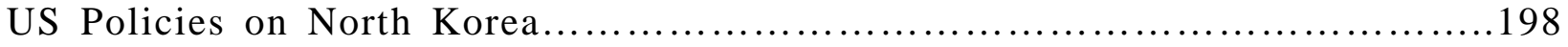

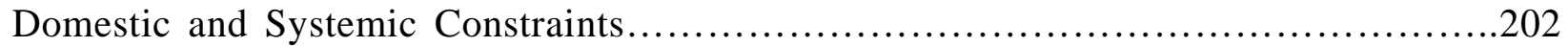

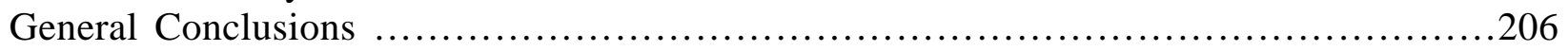

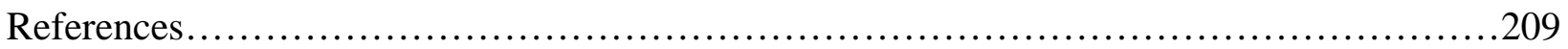




\section{List of Tables}

Table 1: The Road to the Agreed Framework...........................................70

Table 2. Domestic Constraints (Clinton Administration)..................................79

Table 3. Systemic Constraints (Clinton Administration)................................992

Table 4. Clinton's North Korean Nuclear Policy........................................108

Table 5: The Road to the Six-Party Talks in Beijing..................................115

Table 6. Domestic Constraints (Bush Administration).....................................128

Table 7. Systemic Constraints (Bush Administration)..................................137

Table 8. Possible Changes in Bush's North Korean Nuclear Policy.........................149

Table 9. Initial Policies of the Clinton and Bush Administrations...........................157

Table 10. Comparing Clinton's and Bush's Policy towards North Korea.....................169

Table 11. Clinton, Bush and the US Congress.........................................175

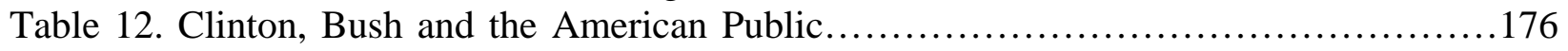

Table 13. Clinton, Bush and the Bureaucracy ..........................................179

Table 14. Clinton, Bush, and Concerned Countries.......................................184

Table 15. Clinton, Bush, and the Kim Regime...................................... 186

Table 16. Policy Shift........................................................... 192

\section{List of Figures}

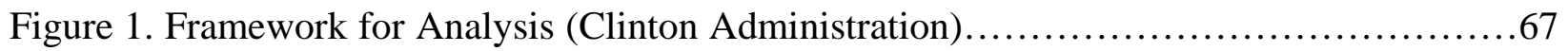

Figure 2. Impact of Domestic Constraints on Clinton's Policy...........................91

Figure 3. Impact of Systemic Constraints on Clinton's Policy.............................101

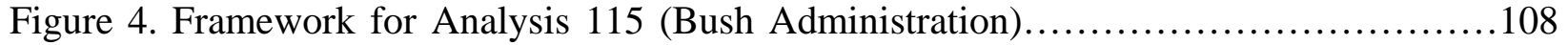

Figure 5. Impact of Domestic Constraints on Bush's Policy..................................134

Figure 6. Impact of Systemic Constraints on Bush’s Policy.................................148 


\section{CHAPTER I: INTRODUCTION AND THEORETICAL FRAMEWORK}

Even a half a century after the Korean War, a dominant problem in United States foreign policy remains the question of relations with the Democratic People’s Republic of Korea (DPRK) and, in particular, that country’s movement toward a nuclear weapons program. Since the 1990s, North Korea's development of nuclear weapons-and the missile technology to develop them-has posed an ongoing crisis for both the Clinton Administration (1993-2001) and, since then, the second George Bush Administration since 2001. Despite the seeming clarity of the threat, dealing with the North Korean regime has involved complex policy choices, ones centering around the pursuit of alternative negotiating frameworks, bilateral or multilateral diplomacy, the precise balance between coercion (sticks) and incentives (carrots), and the extent to which these policy choices are tied to international regimes such as the Non-Proliferation Treat (NPT) and the International Atomic Energy Agency (IAEA). The debates over such policy instruments have attracted much attention throughout the American policy community and academia (see Cha and Kang 2003; Finnegan 1999: 81; Haass 1995: 1-18; Klare 2000: 46-51; Litwak 2000; O’Hanlon and Mochizuki 2003; Pucket 1993; Shimbun 2000; Shirk 1997: 245270; Sigal 1998, 2000; The Aspen Strategy Group 1995; Wolfsthal 1993: 6-9).

The 1990s have, in fact, seen two distinct American policies designed to get the North Korea abandon its nuclear weapons program. During Clinton’s term, a relatively “moderate” policy was pursued in which the Agreed Framework between the American government and the North Korean government would provide North Korea incentives to abandon its nuclear program. ${ }^{1}$ And, in fact, the North Korean government also acceded to the international pressure

\footnotetext{
${ }^{1}$ The Agreed Framework of 1994 was a bilateral agreement between the United States and North Korea in which the latter agreed to "freeze" its nuclear program. The agreement outlined a 10-year program during which the United States, South Korea and Japan will construct two new proliferation-resistant, light-water-moderated nuclear reactors in the DPRK in exchange for the shutting down of all its existing nuclear facilities. In addition, the DPRK agrees to
} 
of signing the NPT. However, the record of North Korean behavior on the matters of nuclear weapons and missile technology was not entirely compliant. The country has continued to show its non-cooperation on the proliferation initiatives. Bush entered office in 2001 with a relatively hard line policy that was clearly more skeptical of North Korean behavior and sought to coerce the country into restraint. Then, barely ten years after the Agreed Framework, the North Korean Government announced on January 10, 2003 its withdrawal from the NPT.

North Korea’s dramatic withdrawal of the NPT set off security alarms throughout the world particularly in the countries in the Asia Pacific Region and among North Korea’s neighbors: Japan, South Korea, Russia, and China (Sigal 1998: 46). Consequently, the decision immensely affected the trade and business, political strategies and policies of countries and the economic and political activities of these countries. Its actions confirmed the hard line views of the Bush administration, which now feared possible domino effect scenarios, propelling states to create their own nuclear programs. North Korea’s refusal to enter into the NPT forged by countries all over the world only heightened the United States' suspicion that it was embarking on nuclear proliferation. As a response to the North Korea's conduct, the country was labeled by the Bush administration as a "rogue state"” and ultimately part of the "axis of evil." From then, and up to the present, North Korea has been a target for security checks because of the potential threat it has brought to the region and to the world. Yet the Bush administration, even in its role at the forefront of the non-proliferation regime, has confronted complex choices involving the attempt to employ several techniques and strategies to halt further development of North Korea's

remain a party to the nuclear Non-Proliferation Treaty (NPT) and accept International Atomic Energy Agency (IAEA) full-scope safeguards.

2 "Rogue" states refer to countries regarded as hostile to the US and its allies and suspected of developing weapons of mass destruction. Though the US State Department discourages use of this term, it is still used by some US officials in reference to NK, Libya, Syria, Iran and Iraq. 
nuclear program (see e.g., Carlson 2003; Choi 2003; Fein 2003; Heginbotham 2003; Kerr 2003;

Koh 2003; Lee and Feffer 2004; Niksch 2003).

In light of this pressing issue on the Korean peninsula, the purpose of this dissertation is to examine and evaluate the conduct of United States policies in addressing the North Korean nuclear threat under the Clinton (1993-2000) and Bush (2001-2004) administrations. Three major areas are examined for both administrations: (1) original policy position towards North Korea upon each entry into office, (2) systemic and domestic constraints that affected the full implementation of the policies as originally proposed by the two administrations, and (3) how each administration adjusted its policies as a result of these systemic and domestic constraints.

Using the method of structured focused comparison, this study considered the divergent policy strategies of the Clinton and Bush administrations in terms of their choices on bilateralism vs. multilateralism, coercion vs. incentives, and the role of international regimes. But this dissertation also considered similarities between the administrations, i.e., the enduring domestic and systemic constraints that had common constraints on otherwise divergent policies. As such, this study shows that Clinton attempted to employ the international regime in the early part of his administration but ended up with the exclusion due to some major constraints; and Bush started and is likely to end with the exclusion of the international regime. This dissertation predicts that, while Clinton employed bilateral approach, the Bush administration would use bi-multilateral strategy toward the end of his second term in resolving the nuclear conflict.

\section{The Dimensions of Policy Choice in U.S. Foreign Policy towards North Korea}

This dissertation is based on the conceptualization of strategic choices underlying the policy alternatives of hard line and moderate foreign policies in how the United States chooses to deal with the threat of North Korea's nuclear weapons program. Three policy dimensions are 
conceptualized in this study: (1) multilateralism and bilateralism as a negotiating framework, (2) coercion (sticks) versus incentives (carrots) in the application of military, diplomatic and economic pressure, and (3) the extent to which international regimes are invoked.

In the study that follows, these will be used to describe the original policy designs of each administration upon entering offices and then, ultimately, examined again to assess how systemic and domestic pressures have constrained the ultimate implementation of administration policy preferences. Given their importance to this study, it is useful to begin by examining each dimension in some detail.

\section{Alternative Negotiating Frameworks: Bilateralism versus Multilateralism}

This dimension of policy strategy concerns the diplomatic framework in which the United States, in the case of this dissertation, engages the North Korea government on its own bilaterally, or as one of a group of states acting in concert vis a vis the North Koreans. Although multilateralism is usually considered to a more moderate policy strategy, in the case of United States-North Korea relations it is bilateralism that is associated with a more accommodating and flexible policy, because of the North Korean demand for direct relations with the United States (O’Hanlon and Mochizuki 2003: 220) for reasons of diplomacy and strategy. In contrast, multilateralism, whereby the United States government acts in concert with China, Russia, Japan, and South Korea, is seen as a more hard line posture in which the United States withholds recognition and forms a coalition against whom the North Korean government must deal.

Policy analysts and scholars are sharply divided over the question of bilateralism or multilateralism in United States-North Korea relations. Certain scholars argue that bilateral talks might be the more effective solution in the North Korean crisis (Juster 2000: 51: Pilat 1994: 129; Sigal 2000: 3). On the other hand, some scholars such as Cha and Kang (2003: 161), Finnegan 
(1999: 81), Haass (1995: 1), Litwak (2000: 198), O’Hanlon and Mochizuki (2003: 220), Puckett

(1993: 120) Shirk (1997: 245), and Wolfsthal (1993: 6) cite the use of a multilateral approach to solve the North Korean crisis. The reasons for their choice of multilateral negotiations as the tool for the resolution of the nuclear problem may differ but the primary contention is the same.

On the one side, some scholars supported the sort of bilateralism employed by the Clinton administration in pressuring the North Koreans. They argue that it is more practical for the United States to employ a multilateral strategy because it can impose sanction together with other countries connected through trade with North Korea, thereby severing the economic sanction, distribute the cost of military expenditure with other countries and for the common security interest of the countries involved. On the other hand, some scholars advocate the use of multilateralism because of the prior failure of unilateralism and bilateral negotiations with NK. Thus, Puckett (1993: 120), and the Aspen Strategy Group (1995: 43) argued that the United States must demand a multilateral approach to the North Korean nuclear issue and more military expenditure to its allies. Multilateralism in the security realm builds on and encourages the network of multilateral economic relations that are developing in the region (Feffer, 2000a).

On the other side of the policy debate are scholars favoring multilateralism. Shirk (1997) reviews the failed attempts of unilateral negotiations with North Korean suggested that the United States Government should use a multilateral strategy because the bilateral strategy used by the Clinton Administration, in addition to its failure to stop the North Korean nuclear program, failed to induce North Korean regime as a normal international actor. Some observers contend that bilateralism should supplement multilateralism (Ferrer 2000b: 45). Another argument is simply that developing domestic and international support for nonproliferation actions is simply not always possible (Pilat 1994: 275). It is suggested that the capability to act 
alone, if needed, is essential. Therefore, a bilateral approach is what is needed in order to gain support both from the domestic and the international arena. As Sigal $(1998,2000)$ describes in his chapter on North Korea, policymakers have turned to engagement because both economic sanctions and military force appear unattractive. Supporting bilateralism, Juster (2000: 51) took the case of Iraq as an example for the success of this approach. He suggested that it was the bilateral negotiations that the US had moderated Iraq's behavior and constructed a positive bilateral relationship. Shirk (1997: 246) concurred this conclusion by asserting that maintaining a balance with North Korea must reaffirm its bilateral alliances and military presence in the region.

\section{Coercion versus Incentives in the Instruments of Statecraft}

The coercion "sticks" versus incentive "carrots" dimension refers how the instruments of statecraft-diplomatic, economic, or military-are employed to influence the North Korean government. One strategy, which would be associated with a moderate strategy, is to provide incentives to induce the North Korean government to give up or curtail its nuclear program through, say promises of economic aid or diplomatic recognition. In sharp contrast, a more hard line strategy of coercion involves essentially imposing penalties on the North Korean government to force it dismantle its nuclear program. Such "sticks" of statecraft would include diplomatic isolation, withholding economic aid, and/or ultimately the threat of military force. Note that these instruments, either coercive or through incentives, can be delivered on a bilateral or multilateral basis.

The use of coercion and incentives is not, however, mutually exclusive, and most of the literature points to a mix of the two strategies. While reward is used to reinforce and encourage a certain action, a sanction is used to punish, deter and discourage. In international relations, the reward and incentive strategies pertain to the choice of reward given in terms of economic favors 
and foreign aid and the punishment which uses military, economic and diplomatic punishment, respectively (Cha and Kang 2003; Litwak 2000; Sigal 1998). The United States has at its disposal several means of statecraft as economic, military and diplomatic approaches which it has used to North Korea. The use of multiple instruments of statecraft means the simultaneous use of the economic, military and diplomatic means of resolving the North Korean crisis instead of using only one, for instance, military to deter the country. Economic, diplomatic and military interventions play a critical role in sustaining the sort of engagement activities that might help prevent proliferation (Niksch 2001: 1-14).

In the case of the United States foreign policy towards North Korea, the Clinton and Bush administrations have used the reward and sanction strategy to deter and stop North Korea’s nuclear program. The Clinton Administration used mainly economic favors to provide incentives for the North Korean government (Sigal 1998). In this approach, nuclear weapons become a bargaining chip that North Korea has to trade for certain political, and economic rewards, whether these rewards are diplomatic recognition or light-water reactors (Berry 1995). Cha and Kang (2003) had illustrated why a carrot strategy would serve best the purpose of the United States of effectively implementing a nuclear nonproliferation program in the country. Their perspectives view carrots as more worthwhile than sticks, and emphasize the responsibility that the world's most powerful nation has in resolving crises through negotiation.

However, due to the perceived failure of the all-carrot strategy employed by the Clinton Administration, many analysts argue that a coercive strategy better addresses the problem, although there are perceived dangers of using sticks in North Korea. Some nuclear proliferation analysts lean toward a strategy giving greater emphasis to a more hard line strategy in which coercion is the dominant form of statecraft (Litwak, 2000), especially on countries that are 
considered as rogue states such as North Korea. This does not preclude a mix of coercion and incentives, but suggests that it is the tone in which they are combined that makes all the difference (Mazarr, 1997). The promise of benefits for nonproliferation, and the threat to punishment for proliferation, must always be present in the United States policy. O’Hanlon and Mochizuki (2003) suggest that the use of both carrots and sticks is not contradictory. The outside world should not give Pyongyang substantial aid and other benefits simply to appease a dangerous leader or solve an immediate security crisis. But if North Korea is prepared to eliminate its nuclear weapons programs, transform the broader security situation on the peninsula, reform its economy, and even begin to change its own society, outside countries can and should be generous.

As of now, the Bush administration has used both economic and military instruments and coercive sanctions in dealing with the nuclear problem (Cha and Kang 2003). This is especially true when the United States punishes North Korea in light of its withdrawal from the NPT in 2003. This study predicts that the stand-off between North Korea and Bush, and some other factors, will force the current administration to use incentives.

\section{The Involvement of International Regimes}

International regimes provide a third element in any strategy, moderate or hard line, designed by a U.S. administration to contain the North Korea nuclear threat, and it has been significant instrument in policies of the Clinton and the Bush administrations. This can be a source of issues and constraints (Elich 2003). The Clinton and the Bush administrations, for instance, used the IAEA and the NPT in order to enforce inspections of undeclared nuclear sites in North Korea (Elich 2003). The IAEA took this posture due at the bequest of United States officials, who were keen on using these inspections to gather more intelligence on North Korea 
and apply pressure to the regime there. The loyalty of IAEA was questioned by North Korea as it was alleged that it passed information on the United States. The IAEA was more preoccupied with maintaining their sanctity with certain countries like the United States through tough posturing rather than preventing proliferation in North Korea. Although an international institution, the IAEA and NPT can serve the interests of hard liners in the United States Government, even if tied to the use of multilateral and coercive strategies.

The leaning of the IAEA and the NPT on the United States is evident in the ability of the Clinton and the Bush administrations to use their means of intelligence and sanctions. Thus, the withdrawal of the North Korea from the NPT stemmed from its substantiated belief that its very survival is at stake due to the Bush administration's influence and threats (see e.g., Cha 2002; Diehl 2002; George W. Bush Administration Policy Toward North Korea 2004; LaMontagne 2002; Sherman 2002).

This threat from North Korea has propelled a worldwide movement that seeks to curtail this massive security threat. The NPT is the most popular multilateral treaty with 187 member countries. Under the treaty, non-nuclear weapon member states pledge that they will not accept nuclear weapons or help to develop nuclear weapons from nuclear weapon states in order to gain negotiations to attain disarmament of nuclear weapon states. An important nuclear nonproliferation treaty, the Comprehensive Nuclear Test-Ban (CNTB), supplements the NPT. This supplementary treaty is signed by 149 nations including five nuclear weapon states. Moreover, for almost ten years, the NPT has been successful in preventing nuclear testing by the North Korean government.

Presumably, the international regime should have ended the nuclear problem in North Korea. However, the NPT, while fostering ties among countries, was disregarded by the Kim 
regime, and, as such, has served as means by which the North Korea government has signaled its hard line positions. North Korea was one of the countries that had continued with its nuclear programs even after signing the treaty (Sigal 1998). Moreover, it violated the provisions of the NPT and the Agreed Framework of the Clinton Administration when North Korea removed the monitoring equipment the IAEA installed at its Yongbyon nuclear complex, expelled the IAEA inspectors resident there, and announced it would resume operations at such facilities as its five megawatt reactor at its spent fuel reprocessing plant. Eventually, on January 10 in 2003, the DPRK announced its withdrawal from the NPT, thus the expressions of concern, if not condemnation, from each of the major powers involved in the issue.

\section{Explaining U.S. Policy towards North Korea: Systemic and Domestic Constraints}

This dissertation does not simply seek to describe United States policies towards North Korea. It also seeks to explain those choices in terms of constraints that affect the extent to which preferred policies could be implemented across the tenure of an administration. Two sets of constraints have been widely considered to influence the US foreign policy towards North Korea since the end of the cold war (see Amini 2002; Axelrod and Keohane 1985: 226-254; Behrens 2000; Busch 2002; Cha and Kang 2003; Eberstadt 1996: 10; Juster 2000). The first set consists of constraints from the international system and, in particular, the power and position of other national actors involved in the Korea crisis. The other set of constraints consists of domestic political pressures throughout the American political system. The premise of this dissertation is that these constraints-at home and abroad-are factors not tied to a specific presidential administration. Rather, as examined here, these factors pose constraints that cut 
across successive administrations and, as such, are common to the Clinton and Bush administrations.

\section{International Systemic Constraints throughout Northeast Asia}

That even great powers face constraints from other powers is, of course, a basic premise of the dominant perspectives, such as neo-realism (Mearshiemer 2001) in which the role of international structures defined by the distribution of power in an anarchic system. Thus, even the United States, a supposedly the dominant power in the post-cold war international order, faces significant constraints in implementing its policies towards North Korea (Cha and Kang 2003; Eberstadt 1996: 12; Juster 2000; Haass 1995; Hayes 2003; Nye 2002). Thus the United States is constrained by other powers in the Northeast Asian region: Russia, China, Japan, and South Korea. In the latter two cases, it is a matter of having the support of key allies who are also very much the targets of North Korean actions. And, although not ally, China's role is especially important because of its special influence over the North Korean regime as one of the few nations with sustained political and economic ties with the otherwise isolated regime. As such, US administrations have to take into account the policy preferences of these governmentsones that might be at variance with the United States' approaches to dealing with the North Korean program. Ultimately, the United States needs the help of the international regime in order to legitimize its actions and gain military support from countries within the Northeast Asian region.

In the case of the North Korean crisis, a second systemic constraint for the United States is the country's regime under the leadership of the Kim. The attitude of the Kim regime has different perspective from that of the United States in terms of how negotiations should be made and how the implementation of the policies should be done. For one, the Kim regime has insisted 
on a bilateral approach, whereas Bush has insisted on a multilateral approach with major countries such as Japan, South Korea, China and Russia. Moreover, the mutual distrust of the US leaders and the North Korean leaders hinders them to create an agreement that they can both abide with. Third, the United States is constrained by its military capabilities: the US military intelligence cannot have access on North Korea and thus, hinders them to create an estimation of the real power of the North Korean military. And while the US military is more powerful than North Korea’s military, the impending threat of a North Korean army that has nuclear weaponry hampers pre-emptive strikes.

The end of the cold war has complicated this environment. With the demise of the Soviet Union, North Korea has been left as perhaps the most potentially threatening and the most unstable actor on the world stage. The suspicion that North Korea has acquired nuclear weapons unsettles not only its neighbors but also the United States. In the longer term, the possibility that Pyongyang might use nuclear arms to blackmail the other East Asian neighbors is worrisome. The most important impact of a North Korean bomb ultimately might be to drive both South Korea and Japan to obtain their respective nuclear arsenals. Thus the United States operates in an environment of great uncertainty in which it must attempt to adopt a strategy that can effectively address the problem of nuclear weapons of North Korea.

\section{Domestic Political Constraints within the United States}

This dissertation also takes into consideration the role of domestic constraints within the American political system. As will be discussed later in this dissertation, domestic political constraints have been characterized in terms of the internal formulation of the policy options for the Clinton (see e.g., Berry 1995; Cronin 1994; Forsythe and Hendrickson 1996; Held and McGrew 1998; Jacobs 1997; Sigal 1998; Sokolski 1995) and Bush (see e.g., Bock 2002; Boese 
2003; Cha 2004; Cossa 2001; Lindsay 2003; McFaul 2002 and Reiss (2004) administrations.

Although contrary to the logic of systemic theory, domestic political factors condition responses to international pressures for several reasons, even in a crisis involving the threat of nuclear war. Domestic politics matters in three ways: (1) the need to resolve debates over the appropriate strategy on North Korea, (2) the appropriation or authorization of resources for carrying armed conflict or signing agreements, and (3) the ability to pursue a public policy toward North Korea that is a the forefront of mass politics in the United States., e.g., how to sell a policy in which the government makes concessions or risks war with an aggressive authoritarian regime.

Three imminent domestic constraints limit the power of the United States Government in solving the nuclear issue: the Congress of the United States, public opinion and domestic culture, and the bureaucratic and decision-making politics measured in terms of struggle between Defense and State departments and presidential limitation in policy decision. The US Congress, in particular, as part of the legislative branch of the government, is deemed a constraint because of its inherent power to direct and appropriate financial, military and formulate treatises (Burgin, 1992: 217-242). Moreover, the partisanship in the Congress has proven to be a crucial determinant of the success of the United States' policy on North Korea. In other words, the interplay between the two major political parties in the United States, the Republican and the Democrat, has molded the country's foreign policies. As will be argued later in this dissertation, both the Clinton and the Bush administrations have encountered both support and opposition from the US Congress that led to the changes in their policy formulation and limitation in mustering the use of military, economic and diplomatic means.

The second domestic constraint is the public opinion regarding rogue states and proliferation. Public opinion either softens or hardens policy positions and implementation; and, 
in our case, the Clinton and Bush administrations operated/operates on the context of public opinion and the diplomatic culture of the American people. Being at the forefront of democracy, US policy makers contemplating the deployment of troops into a situation—whether unilaterally or multilaterally, or sanctioning or providing aid—should sensibly consider the value the public places in the venture, and then they may try to use whatever persuasive skills they possess to enhance this value. This means marketing foreign policies to the general public.

The third constraints include the bureaucratic and decision-making politics measured in terms of struggle between Defense and State departments and presidential limitation in policy decision, the conflict and limitations within the executive branch of the government create inconsistencies and lack of coordination that leads to the inadequacy of convergence of actions. Intelligence is a significant factor in foreign affairs than it is today. One of the major problems about intelligence bureaucracy and international relations is the deficiency in understanding historical context. Often, commentators attack and support the challenges facing intelligence communities without reflecting on the historical forces that have shaped these communities over the last centuries (Jackson and Siegel 2005).

\section{The Significance of Constraints on the U.S. Foreign Policy}

The importance of these constraints, i.e., the mix of international and domestic pressures, is that they affect the implementation of any administration's original policies. The argument is that both the Clinton and Bush administrations will face significant constraints that will diminish the differences in their original policy strategies. This dissertation will, for example, illustrate that Bush policy approach and implementation strategies towards the NK problem would be similar to that of Clinton's policy stance and implementation strategies. Bush's policy is likely to have a similar policy path which focuses on bilateral negotiations within the context of a 
multilateral forum (e.g., the Six-party talks), a leaning towards economic rewards and the exclusion of the international regime.

While the two administrations started on different policy paths-Clinton favoring to use bilateral negotiations, rewards or incentives based mainly on economic favors and aids by predominantly using economic and diplomatic means and employing the aid of the NPT and IAEA in the negotiation and containment process (Niksch 2001), whereas Bush utilizing military and economics as the primary deterrent for the North Korean nuclear threat-this study expects that the latter administration would adopt a moderate approach in the end.

The findings of this dissertation have important policy implications. This dissertation’s investigation of the domestic and systemic constraints faced by both administrations beginning from the formulation policy frameworks, to the actual implementation of the policies and the changes that took place in the course of these administrations. This study shows that the domestic and systemic constraints are the main reasons for the inability of the United States to resolve the North Korean crisis.

\section{Research Questions, Methodology, and Case Selection}

The ultimate goal of this dissertation is to assess the impact of domestic and systemic constraints on the ability of the United States to pursue an effective policy for containing the threat of North Korean nuclear proliferation. It examines foreign policies of two United States presidencies-those of the Clinton and second Bush administration-with respect to three areas of policy choice: bilateralism vs. multilateralism, carrots vs. sticks, and the role of international regimes. Noting that, upon entering office, these two administrations proposed distinctly different policies towards North Korea, it then examines how domestic and systemic constraints influenced each administration in the implementation of their respective policies. A key point of 
the dissertation is that the two administrations faced similar constraints and, as a result, the differences in their policies ultimately narrowed over time. Thus, this study seeks to identify the domestic and systemic constraints in order that the present and the future US administrations can resolve the constraints before embarking on a policy approach.

A methodology of structured focused comparison, developed by George (1979: 42-68; see also Bennett and George 1997), was utilized in this study in order to illustrate and systematically compare the domestic and systemic constraints on the implementation of the Clinton and Bush administration policies. As originally articulated by George (1979), the use of structured focused comparison is actually the building block for theory development. It is a comparative study between two cases where the method is focused in that it deals with only certain aspects of the cases; that is, a selective theoretical focus guides the analysis of the cases. The method of doing so is structured in that the same general questions are asked of each case in order to guide data collection, thereby making possible systematic comparison and accumulation of the findings of the cases. For this study, the selective theoretical focus is the domestic and systemic constraints in the use of multilateralism and bilateralism, reward and sanction and the use of economic, military and diplomatic.

Structured focused comparison was applied in the three components of the research design. The first component, the identification of the initial policy of the Clinton and the Bush administrations, was compared through the initial policy position with respect to the preferred framework of negotiation, the mix of inducements versus coercion, and the role of international regimes. Second, the process of the approval of the proposed policy of Clinton and Bush was identified including the support or the opposition it received from the US Congress and public opinion. The problems in terms of the policies such as the appropriation for the North Korean 
regime, the military support and the implementation support in terms of financial and military mandate were compared and contrasted between the two administrations. Finally, the final policy position of the Clinton and the Bush administrations, i.e., at the end of their terms, were compared with respect to the three originally policy dimensions: the preferred framework of negotiation, the mix of inducements versus coercion, and the role of international regimes

Following this methodology, the dissertation addresses the following specific questions for the two administrations:

1. What are the initial policy positions of the Clinton and second Bush administrations to North Korean nuclear proliferation with respect to:

a. Negotiating Framework bilateralism versus multilateralism

b. Instruments of Statecraft: Inducements “carrots” versus Coercion “sticks” c. International regimes particularly NPT and IAEA exclusion or inclusion

2. What are the similarities and the constraints in the domestic level in the policy formulation, strategy and implementation of the Clinton and Bush Administration on North Korean nuclear threat in terms of:
a. U.S. Congress
b. American diplomatic culture and public opinion
c. Bureaucratic institutions and politics

3. What are the similarities and constraints in the systemic level in the policy formulation, strategy and implementation of the Clinton and Bush Administration on North Korean nuclear threat in terms of:
a. Coordination with South Korea
b. Coordination with Japan 


\section{c. Coordination with China \\ d. Coordination with Russia}

The thesis of this dissertation is that the domestic and systemic constraints faced by the Bush and Clinton administration will lead to a greater similarity, in other words, convergence, of their policies with respect to the mix of bilateralism versus multilateralism, reward versus coercion, and the role of international regimes?

The data collection started chronologically. The history of the North Korean proliferation regime and the initial policies implemented by the United States’ past presidents were first outlined. Then, the Clinton policies and strategies from the initial policy stance of the Clinton administration, the changes in the policies, the preparation and the implementation of the August 12, 1994 Agreed Framework were evaluated. The data collection consisted of official documents of the United States and North Korea, policy briefs, proceedings, journal articles and books. Similarly, the data collection on the Bush administration started chronologically_ from Bush's assumption to office and the formulation of policies, to the Axis of Evil speech, the withdrawal of North Korea on the NPT and the holding of the three rounds of the Six Party Talks (first round, August 27-29, 2003; second round, February 25-28, 2004; third round, June 23-26, 2004). It is appropriate to close this chapter with some comment on the wider relevance of this study. The administrations of Bill Clinton and George W. Bush were chosen for the study because of the differences in their foreign policies and approaches to the North Korean nuclear problem. The approach taken by the current Bush administration rested on the relatively hard line perspective that rogue states and those who engaged in proliferating weapons of mass destruction (WMD) must be dealt with in a firmer way such as the use of military strategy to stop their operations (Sigal 1998; T. H. Kim 1993: 3-7). On the other hand, the Clinton administration 
favored the use of diplomatic approaches and negotiations with a leaning towards economic sanctions in resolving North Korea's nuclear threat (Gordon 2003). The two administrations offer theoretically examples of clearly different orientations to dealing with the issue of North Korea nuclear weapons while also facing similar levels of domestic and international constraints.

The other value of this study is, though, its policy relevance. It was made with the primary purpose of identifying the domestic and systemic constraints in the policies and implementation of the Clinton and Bush administration on North Korea's nuclear program from the perspective of a military officer from South Korea. The findings of the research is an attempt to provide a critical analysis for policy makers, military officials, government officials and the succeeding Presidents of the US, China, Russia, Japan and South Korea. Moreover, the research sought to contribute to the literature on the policy formulation and implementation of policies on rogue states such as North Korea. It also seeks to fill a gap in scholarly research from the point of view of South Koreans and from Asians on the issue of the foreign strategy employed by the United States on North Korea. The distinctiveness of the Asian culture may be a factor in the failure of the US government to provide an approach that can cease or cease the nuclear program of North Korea. Thus, instead of the usual Western scholars analyzing the issue of nuclear proliferation and the possible approaches to mitigate the North Korean nuclear problem, this study is an attempt to provide a Korean perspective of the problem and on the ways that it can be solved. The experiences of the researcher as a member of the military and being a Korean may provide insightful recommendations in resolving the problem of nuclear threat by North Korea.

The scope of this investigation is limited to only two administrations in the handling of the North Korean nuclear threat. The scope of the study covers the years 1990s up to the present. The analysis of this dissertation cannot be generalized to that of the other rogue states because of 
the differences in the history of the regime of North Korea and its relationship with the United State. Moreover, this study is not an attempt to find the best policy and implementation strategy that will put a resolution to the North Korean nuclear problem but rather. It, however, sets a standard in finding the right policy by first identifying the constraints both systemic and domestic. This will guide policymakers and government officials in adopting a policy and implementation strategy that can finally put a closure to the North Korean problem and to other similar problems. Finally, this study did not cover the whole term of Bush and covered only the period until the first half of 2004. Further changes in the Bush policy approach and implementation strategy after that period are included but are not discussed in detail. 


\section{CHAPTER II: The North Korean Nuclear Crisis}

Throughout the course of its attempts to produce nuclear weapons, North Korea has joined, violated, and withdrawn from the Nuclear Non-Proliferation Treaty (NPT), a decision that has sparked international concern over nuclear proliferation, as well as regional concern about the possibilities of an imminent crisis. Today, North Korea remains isolated, near economic collapse, and faces yet another potentially devastating humanitarian crisis. As such, it is arguable that a resolution to the nuclear threat will only bring about genuine development in the country, and peace in the region. However, due to the historically obscure nature of the North Korean regime, the challenge of finding a speedy resolution to the crisis is aggravated.

The North Korean nuclear crisis has been addressed by the United States using several strategies and policy options. Yet the problem persists, mainly due to the perceived domestic and systemic constraints that have impeded and hampered the process of resolving the North Korean threat in both the formulation of policy, as well as in the actual implementation of the policies of the Clinton and Bush administrations. This chapter illustrates the rationale, the nature and the role of North Korea's nuclear program to its regime, and addresses the American foreign policy towards North Korea, with specific emphasis on the Clinton and Bush administrations.

The first section of this chapter discusses the history of the North Korean Nuclear Program, and illustrates the rationale for cultivating a nuclear weapons program. The current North Korean nuclear crisis cannot be fully understood without reference to both the record of nuclear ambitions of North Korea and its current economic and security plight, two factors that, when fused together, offer an explanation of the current crisis based firmly on the desire of the North Korean regime to ensure its own survival. 
The second section illustrates the nature of American foreign policy towards North Korea by providing an overview of Clinton and Bush administration policies and subsequent discussions on the Agreed Framework by Clinton and the Six-Country Talks by Bush. The U.S., as well as such countries such as South Korea, Japan, China, and Russia want long lasting peace in the region. The third section details the policy and implementation strategy of the Clinton administration, including the bilateral approach that utilized an incentive-based economic reward attained through diplomacy, as well as the exclusion of international regimes, such as the NPT and the IAEA during the latter part of negotiations. The last section evaluates the policies and implementation strategy of the Bush administration, from its initial policy stance of using multilateral, militant, and the exclusion of the international regime and the possibilities of Bush going through the same policy path of Clinton which rested on a bi-multilateral talk which uses economic and diplomatic means and the exclusion of the international regime.

\section{The North Korean Nuclear Crisis}

The current nuclear crisis in North Korea started from events that happened more than five decades ago, when, after the Second World War II, Japanese troops north of the 38th parallel that divides the Korean peninsula, surrendered to Soviet forces, while those at the south of the line surrendered to US forces (Galdi and Shuey 1988: 109). ${ }^{3}$ Despite declarations made at the 1943 Cairo and 1945 Potsdam Conferences, which envisioned a united and independent postwar Korea, North Korea fell under Communist occupation.

Following the failure of negotiations aimed at reunification in 1946 and 1947, free elections, under the aegis of the United Nations, were held in South Korea. While this resulted in a declaration by the UN General Assembly that the elected Government of the Republic of Korea

\footnotetext{
${ }^{3}$ For the sources on the history of North-South Korean Conflict, see generally Kaufman (1999). See also Han and Levin (2002), specifically Chapter 2, and Chung (2003).
} 
to be the official and lawful government in Korea (Pires 1994: 307), they also pushed North Korea to sever all political and economic ties to the South, and terminate electric power transmissions. Moreover, in September 1948, a rigged election resulted in the establishment of the Democratic People's Republic of Korea (DPRK) as the governing body of North Korea.

Tensions between the two sides were exacerbated when, on June 25, 1950, North Korean military forces crossed the 38th parallel, and occupied almost all of South Korea. Three days later, the United States responded by deploying troops against the DPRK, and the United Nations Security Council called upon Member states to aid South Korea in repelling the armed attack and restoring peace and security in the region (Pires 1994: 308). By early July, U.N. forces were deployed under US General Douglas MacArthur. Despite initial successful advances after the famous Inchon landing in mid-September, the UN forces were pushed back by an influx of Chinese "volunteers" until the front lines stabilized along approximately the 38th parallel in the spring of 1951 (Galdi and Shuey 1988: 109). The combat ended with the signing of an armistice on July 27, 1953.

Since 1953, the two Koreas have maintained an immensely hostile relationship. Numerous border provocations have culminated into open, though undeclared, conflict between 1966 and 1969 and "the North Korean government has since sanctioned terrorist attacks on a variety of unlawful targets, including the President of South Korea, South Korean cabinet members, and the general civilian population of South Korea” (Newcomb 1994: 629).

In 1985, North Korea confirmed its membership to the NPT and agreed to the following: to accept safeguards on all fissionable material; to provide a preliminary accounting of materials and facilities; to maintain a system for accounting and control of fissionable materials; and to provide annual reports of safeguarded materials inventory. Moreover, North Korea complied to 
ad hoc, routine, and special inspections by the IAEA in order to ensure compliance with the terms of the IAEA/DPRK Safeguards Agreement (Treaty on Nonproliferation of Nuclear Weapons, 1968: Art. 2).

However, North Korea's acquiescence had been questionable from the outset (Newcomb 1994: 629). The country took a defensive position when the IAEA insisted inspections. Thus the tension between the United States and North Korea resumed. The IAEA took this posture due at the bequest of US officials, who were keen on using these inspections to gather more intelligence on NK and apply pressure to the regime there. At this time, North Korea discovered that the IAEA inspectors were in fact passing intelligence about North Korean nuclear sites to United States officials in violation of their mandate (Elich 2003).

Eventually, concerning the intrusive inspection by the Agency, the North Korean Minister of Atomic Energy announced the government's intent to withdraw from the NPT in 1993. The Agency's Board of Governors determined that the North Korean actions were not in compliance with the NPT and reported these findings to the UN Security Council and the UN General Assembly. In an attempt to defuse the situation, Clinton decided to restart political discussions with North Korea (Newcomb, 1994: 603).

North Korea's defiance of the NPT was further, and explicitly, exemplified by its testing of Scud ${ }^{4}$ missiles in May 1993 (Sigal 1999). This compelled the United States to pressure Israel to discontinue negotiations aimed at offering North Korea investment and recognition in return for canceling its missile sales in Middle East countries (Brower 1994: 376).

The Clinton administration charged that plutonium extracted from North Korea's

\footnotetext{
${ }^{4}$ Scud is not an acronym. It refers to the NATO reporting name for a Soviet army short-range liquid propellant surface-to-surface ballistic missile, the SS-1. North Korea had been producing the missiles in the early 1980s, but their inaccuracy during this period hindered their value to being effective only as weapons of terror aimed at large cities.
} 
Yongbyon nuclear facility was being utilized in the development of nuclear weapons, and that as such, North Korea must be prevented from developing a nuclear bomb (Elich, 2003: 1). When formal talks between the United States and North Korea broke off in 1994, the United States began pressuring the UN Security Council to impose sanctions, a move considered in Pyongyang as an implicit declaration of war (Elich, 2003: 1). Despite warnings from the Security Council, North Korea removed 8000 spent fuel rods from a five megawatt nuclear reactor in Yongbyon, thus hiding potential evidence that would determine whether the country possessed sufficient raw materials to construct a nuclear bomb (Butler et al. 1994: 30). When Clinton persisted in attempting to impose international sanctions, North Korea openly tested Silkworm ship-to-ship missiles. According to former Defense Secretary William Perry, the United States was "within a day of imposing severe sanctions on North Korea...We were within a day of making major additions to our troop developments in Korea" (Koch 1999: 21).

Tensions seemed to thaw with an agreement to allow the resumption of IAEA inspections at the Yongbyon plant, secured during a visit be Jimmy Carter (Sigal 1998), and then with official negotiations in1994 that ultimately led to the signing of the Agreed Framework. According to the terms of the agreement, North Korea would freeze its nuclear program in return for western assistance and capital to build light water reactors, which produce less of the plutonium that can be reprocessed to make bombs (Agreed Framework 1994). However, despite the cooperation of South Korea and the United States, North Korea continued to maintain a heavily armored conventional military force just north of the demilitarized zone, and despite the great expense to its country’s security and credibility, it continued to develop its military capabilities (US Department of State 1996).

Situations became bleak once more when, on August 31, 1998, NK launched a three- 
stage Taepo Dong rocket over Japan in an unsuccessful attempt to put a satellite into orbit (Weinberger 1999: 42). It has been argued that the launch had a dual purpose: first, to provide a visual and public demonstration of the country's missile technology, and, second, to serve as a bargaining chip to win concessions from the United States. The Italian La Repubblica, for example, argued: "The North Korean government has stated very clearly that it will continue to produce and sell missiles up until the time the U.S. lifts its economic sanctions.... Therefore, arms production ... has become North Korea's most important diplomatic ... tool to try and obtain concessions from the U.S. and the other Asian countries without making any significant concessions of its own” (Beal 1998: 14).

Some, however, defended DPRK. Egypt's Al Ahram, for example, argued: “But there is exaggeration in the reactions to it because the Far East and the whole world are full of missiles. This international situation gives the right to any country to develop its missiles to protect its security. For these objections to have credibility, the objecting countries should declare a binding program to destroy their own missiles under an international program of comprehensive disarmament, to be applied on all countries equally. The world will not accept being divided into countries that have the right to produce weapons of mass destruction and threaten the rest, while other countries are denied this right” (Beal 1998: 14).

In response to North Korea’s aggressive moves, US warplanes conducted a mock exercise to simulate a long-range mission to drop nuclear bombs on North Korea (Kristensen 2002:54-59). The American National Intelligence Estimate thought that North Korea also intended to test a new missile, the Taepo Dong 2, which was believed to possess sufficient range to strike Alaska and Hawaii with up to a 300-kilogram payload. The gravity of the situation was intensified by a US intelligence belief that this level of weaponry would have sufficient capacity 
to deliver a nuclear payload, and Taepo Dong 2 could probably reach the rest of the United States, depending on the size of its payload (US Senate, Committee on Foreign Relations, April 20, 1999).

Nonetheless, North Korea continued to allow IAEA inspectors to visit various sites in their country in exchange of food aid, inspections that produced no evidence of nuclear activity (Cumings 2001). In 2000, Kim Jong-il and his counterpart from the South, Kim Dae-jung, held a summit in Pyongyang, aimed at continuing a process of détente between the two neighbors (Watts 2000). Yet while these countries were in the process of easing tensions between one another, relations between the United States and North Korea continued to deteriorate, reaching a new low after Bush accused Pyongyang of developing missiles and weapons of mass destruction, and singled out NK, along with Iraq and Iran, as belonging to an "axis of evil" (De Young 2002: A1).

In October 2002, the United States issued a statement claiming that North Korea had admitted the existence of a secret program to develop nuclear weapons (The Guardian October 17, 2002), using enriched uranium instead of the previous reprocessed plutonium method (Gittings 2002a). Though a clear violation of the 1994 accord, North Korea went further arguing that it would only abandon its nuclear program entirely if the United States would sign a nonaggression treaty (Grittings, 2002b). In a joint response, in November, 2002, the United States and Japan suspended fuel oil shipments to North Korea (Grittings 2002b). The following month, North Korea rejected a call from the IAEA to open up its nuclear facilities (Jeffrey 2002a), and then proceeded to expel the inspectors, remove monitoring equipment, and then announced that it would reactivate the plutonium-based Yongbyon reactor (Jeffrey 2002b). Gregory Elich (2003) claimed that the IAEA itself indicated that it would prefer that North Korea abandon the NPT 
rather than have to work with the regime there. This was also the claim of Nikhil Shah (2003), who cited Sigal (1998: 97), in his article, “North Korea and International Law.” It was perceived then that the IAEA was more preoccupied with maintaining their sanctity with certain countries, especially with the United States through a tough posturing, rather than preventing proliferation in North Korea (Sigal 1998, in Shah 2003).

\section{Motivations for the North Korean Nuclear Program}

Understanding why North Korea continues to build up nuclear weapons will help US policymakers to design and develop the most appropriate and effective approach and strategy in dealing with the nuclear crisis. The rationale for the North Korean nuclear program has been hotly debated. On one hand, it is argued that it serves as a defense for the regime. On the other hand, it is argued that the nuclear build up is for the accumulation of power and to threaten other countries. $^{5}$

What are the motives that drive the quest for nuclear weapons? Fear and the quest for power and prestige have been the major causes for the proliferation of nuclear arms (Bailey 1993). For one, many leaders are highly motivated to develop nuclear weapons because they symbolize power and offer a means of wielding significant influence in the international arena (Wessels 1995: 56). Nuclear weapons are perceived to be a potent source of military and political power, and, with the power vacuum created by the collapse of the Soviet Union, cautious regional rivals seek to obtain nuclear weapons to achieve regional dominance. Alternately,

\footnotetext{
${ }^{5}$ Saunders' (2000) Internet article, “Assessing North Korea's Nuclear Intentions” argues that North Korean leaders have strong incentives to conceal their true intentions in order to maximize their bargaining power and to minimize international reactions to their nuclear weapons program. See also Park (2000) for the North Korean motivation for proliferation. Park explains Pyongyang's policy behavior by examining the policy goals, strategies, and tactics that the DPRK has employed in the post-cold war years. The following sources attempt to give some background in North Korea's motivation for proliferation: Bermudez (2001), Downs (1999), Friedman (2003), Litwak and Reiss (1994), North Korea's Clandestine Nuclear Weapons Program (2002), North Korea's Nuclear Arsenal: Motivation, Doctrine and Possible Employment (1996), Power (2003), Roy (1996-1997), Sigal (1998), and Taylor (1994).
} 
nuclear weapons serve as equalizers in situations in which the leaders of one nation feel militarily inferior to a regional adversary. Nuclear weapons also effectively bestow significant power on subnational groups struggling for independence, as well as on terrorist groups and nuclear blackmailers (Wessels 1995: 48).

Furthermore, nuclear weapons are viewed as a source of economic control. In cases such as Ukraine and North Korea, nuclear weapons serve as a bargaining chip to gain control of desperately needed hard currency and economic assistance from other countries, especially the US. At the same time, nuclear weapons mean technological prowess and elite status of the declared nuclear weapons states. Others, mostly developing nations, even perceive a correlation between the declared possession of nuclear weapons and a permanent seat on the UN Security Council (Thakur 1993: 7).

Nuclear programs also serve as a powerful instrument in the intense struggle for identity and nationalism in ethnic conflicts that have erupted around the world (Tajfel and Turner 1979: 33). As status competition is a major motivation in the search for identity, the development of nuclear weapons provides a powerful means of increasing the status of one's group. In this regard, it is perhaps possible to empathize with North Korea, who has been overshadowed by its adversaries (especially the U.S.), its relatively powerful neighbors (Russia, Japan and China), as well as by an economically more prosperous South Korea (Wessels 1995).

Arguably, the dominant motivating factor in developing a nuclear program is security. As illustrated by the United States-Soviet Union confrontation during the Cold War, mutual fears induce strong enemy images of an adversary that is monolithically aggressive, diabolical, and untrustworthy (Silverstein 1989: 903). With the adversaries holding equally negative images of the other (Bronfenbrenner 1961: 45), the ability for each side to misperceive the enemy's intent 
becomes more pervasive (Silverstein 1992: 905). Moreover, while the leaders of each nation may seek weapons for defensive purposes, they will tend to perceive the adversary's weapons as being primarily offensive in character, thus presenting the problem of drawing a tight distinction between defensive and offensive weapons, or to advocate the proliferation of defensive weaponry (Wessels 1995). Moreover, these reciprocal perceptual biases provide dangerous contributions to arms races, and a cruel spiral process of hostile interaction (M. Deutsch, 1983). In sum, the regional instabilities and security fears invite enemy imaging, misperceptions, and malignant spiral processes that contribute to the quest for nuclear weapons (Wessels 1995).

\section{Economic Situation}

It is arguable that through the maintenance and cultivation of a nuclear program, North Korea is attempting to achieve a broader goal of unifying North and South Korea. Not only has this assertion taken form through economic and military actions, it was explicitly stated during the regime’s creation in 1948, that the primary national goal was not merely state survival and the protection of sovereignty, but victorious unification - or unification through victory of Communism - over the rival regime in the South (Ambrosius 2003).Both sides in the Korean War wanted more than a continuing division of the peninsula, but neither attained its goal. Kim Il-sung and Syngman Rhee each wanted to unite the country under his own leadership (Ambrosius 2003).

It must be emphasized that the economic superiority of South Korea came about only after THE EARLY 1980S. Indeed, throughout the first three decades of the Cold War, the two regimes faced off as relative equals, each buttressed by security guarantees from their greatpower patrons. Moreover, from the early 1960s to the 1970s, North Korean gross national product (GNP) per capita, as well as its conventional military capabilities, rivaled, if not 
surpassed, that of its southern counterpart (Eberstadt 1996). This relative equality enabled each regime to nurture its own particular vision of political unification, which essentially meant domination of one over the other for each side.

However, for North Korea, the goal of overthrowing South Korea became unrealistic because of the insurmountable gap of economic developments between the two countries, and, most especially, the outbreak of the Cold War led to the disintegration of the USSR and China as patrons. The nearly twenty-fold gap in the gross domestic products of the two countries and the per capita income difference amounting to $11: 1$ shows the economic gap of the two countries (Noland 2001). This has also shifted the paradigm of the North Korean government's core principle-from the goal of communization to self-dependency as the ultimate revolutionary goal.

Immediate survival for a political regime depends upon its capacity to maintain a functioning economy (Noland 2001). In the North Korean case, the state has been experiencing food crisis for more than a decade, and estimates show that a famine in the late 1990s alone resulted in the deaths of almost a million people (Noland 2003). North Korea's failure to provide even the most basic conditions for human existence has caused an increase in the black market economy, the spread of foreign (particularly US) currency, a surge in migration flows across the Chinese border, widespread electricity shortages, and inadequate infrastructure undermining modernization attempts.

Despite humanitarian and development assistance which has ameliorated the situation, the country is once again on the verge of another famine (Noland 2003). While conditions have improved somewhat since the peak of the crisis in 1996-97, chronic food shortages remain, and are likely to continue (Global Security April 22, 2004). Alarmingly, the United Nations World 
Food Program (UNWFP) predicts another severe humanitarian crisis, with famine conditions in the coming years. Moreover, with the expenditure preferences of the regime, the North Korean economy is not producing enough output to sustain its population; and population maintenance has become increasingly aid-dependent. Yet, the exposé of a nuclear weapons program based on highly enriched uranium in October 2002, followed by North Korea's subsequent withdrawal from the NPT, have put continued international assistance in doubt (Noland 2001).

North Korea desperately needs the economic and diplomatic rewards from the United States, South Korea, China and Japan. According to available data (mostly from the late 1990s), North Korea’s major trading partners include China, Japan, and South Korea. Russia, a major trading partner before the collapse of the Soviet Union, was of declining importance a decade ago, and now accounts for less than three percent of North Korea’s total merchandise trade which is about the same as Germany. China is by far North Korea’s most important economic partner, allowing it to run large trade deficits (Noland 2000, 2003). Substantial economic disruption could increase the risk of either a North Korean military response, or internal economic collapse, both of which would be detrimental to regional stability (Noland 2003: 2).

The volume of potential economic leverage is limited because of North Korea's selfimposed isolation. Still, if China, Japan, and South Korea successfully cooperate, the sanctions would cover more than 50 percent of North Korea's reported trade flows, well above the average in past successful cases (36 percent in difficult cases) (Noland, 2003). The façade of North Korea's relative autarky is that its trade is not large enough to be of much economic importance to its partners. Concerns about these potential costs were major factors dictating a cautious strategy in the earlier crisis and remain an impediment to gaining the co-operation of key partners (Elliot 1997). 
Although North Korea may find a vital security interest in acquiring nuclear weapons, they argue that the regime has an even more convincing interest in securing outside help for its failing economy. Indeed, it is in this argument that the United States and South Korea maintain their long-term bargaining edge, and thus Pyongyang ultimately would have no choice but to trade its nuclear option to secure its economic future. However, if the economic imperative were more significant than the security imperative, one would expect North Korea to have given some indication of the economic and political price it would demand in exchange for agreeing to intrusive inspections. In fact, from the summer to the fall of 1994 in shaping the Agreed Framework in Geneva, North Korea showed that it was willing to cooperate with the United States. The DPRK was even keen on accepting intrusive inspections in exchange for massive economic aid and political concessions from the United States in 1994 and in the fall of 2000.

Moreover, while evidence strongly suggests that North Korea is firm in its stand to continue with its nuclear weapons program, it does not explain how the country will cope with its faltering economy. Indeed, North Korea's problem is not simply coping with its extant economic crisis but the prospect of dealing with a much more serious crisis if UN sanctions are imposed as well.

\section{Security Threats}

In order to preserve a regime, it must be able to defend itself. As part of its revolutionary ideological heritage, North Korea claims that its security is threatened, confronted by the increasing superiority of the US military as evidenced by the Gulf War and the Afghanistan conflict and by the future overwhelming superiority of US Forces emboldened by a successful Iraq conflict and rapidly building advanced National Missile Defense (NMD) technology (Commonwealth of Australia 2003). Specifically, North Korea justifies its nuclear program as: 
(1) providing a countervailing deterrent against US nuclear threats, which continue to exist in the form of the nuclear umbrella ${ }^{6}$ held over South Korea; (2) countering the possibility of a future South Korean bomb (indeed, South Korea’s involvement in nuclear activities in the 1970s provided an early incentive for the North's bomb program); (3) deterring South Korea’s overwhelming conventional military superiority; (4) compensating for the loss of its nuclear ally, Russia; and (5) ensuring that the North Korean regime is taken seriously as a major player in the region, even though its economy may be in crisis (Mack 1994).

Indeed, there are different schools of thought on the motivations behind North Korea's nuclear weapons program. On the one hand, those who believe North Korea is a revisionist state argue that the nuclear motivations constitute a serious external threat. Evidence for these claims includes North Korea's initiation of the Korean War, acts of terrorism, forward-deployed military forces, a constitution whereby the DPRK is the sole legitimate government for all of Korea, and Korean Workers’ Party bylaws calling for a completion of the revolution in South Korea. Many analysts further argue that Pyongyang’s record of exporting ballistic missiles indicates that North Korea would also be willing to sell nuclear materials, technology, or complete nuclear weapons (Nuclear Threat Initiative 2004).

On the other hand, a second argument finds that North Korea's nuclear motivations are naturally defensive, and designed to deter external threats to the state. Evidence supporting this claim includes the July 4 North-South Joint Communiqué of 1972; the Agreement on Reconciliation, Nonaggression, and Exchanges and Cooperation between North and South Korea of 1991; the Joint Declaration on the Denuclearization of the Korean Peninsula of 1991; the summit meeting of 2000; the Agreed Framework with the US; and reunification proposals that

\footnotetext{
6 "Nuclear umbrella” is a polite way of saying that, under certain circumstances, the US would use nuclear weapons against NK.
} 
would recognize "two systems" for North and South Korea.

The DPRK doubtlessly appreciates that with its weakened economy, its ability to continue the high levels of military expenditure is decreasing daily, and the economic goal shift from communization to self-dependency has led to the debate on the real intentions of their nuclear weapons, and bears direct correlation to deterrence.

In the discussion of security threats as a motivation for nuclear proliferation, it is important to consider the general strategic uses of nuclear weapons: offensive, defensive, and deterrent (Jung 1996). ${ }^{7}$ The offensive use of nuclear weapon does not provide an attractive option for North Korea, as it opens the possibility of the country to severely exacerbate tensions with South Korea or Japan, thus forcing regional instability, or the United States, thus creating scenarios that are not viable. Defensively, the use of nuclear weapons is far less enticing, as utilization would thus mean application against an advancing adversary, in order to repel it back to its pre-offensive position. Moreover, nuclear defense strategies are limited in development, for the obvious reason that a nuclear defense means using nuclear weapons within, or near, one's own territory.

Amid the offense/defense debate, the DPRK perceives the nuclear deterrent as essential to its defense (Cha 2002: 79-92). However, rather than using a deterrence method to stabilize the balance of power, as is done by the United States, North Korea relies on a rationale of existential deterrence, which, as Cha (2002) describes, implies that the mere existence of nuclear forces provides an irreducible risk that an armed conflict might escalate into a nuclear war. This persistent fear of escalation is thus factored into political calculations, and states, as a result, tend

\footnotetext{
${ }^{7}$ For some information pertaining to the strategic use of nuclear weapons, see generally Mulley (1962). See also Ertman (1993), Young-Hui (1993), Mack (1993). And “A Nuclear North Korea: The Choices Are Narrowing” (1994).
} 
to be much more cautious and prudent than they otherwise might be. Security for the proliferator is therefore achieved not through assured second-strike capability, but by creating first-strike uncertainty. Indeed, deterrence and security derive from having just enough capabilities to raise uncertainty in the mind of the opponent so that it cannot neutralize with a first strike (Karl 2001: 1002-1022).

According to theorists, existential deterrent doctrines, or the capacity to deter threats to the state's survival, are most likely among proliferating states that are small, limited in resources, and with proximate adversaries (Cha 2002). The DPRK's well-documented economic difficulties in the 1990s impose severe resource constraints on closing gaps with rival competitors through modernization and a buildup of conventional forces. The self-help imperatives of anarchy also render reliance on allies for security an unattractive proposition or an unfeasible one. Nuclear weapons, therefore, offer the most efficient means by which to optimize security needs, abandonment fears, and resource constraints. However, as long as anarchy defines the international condition, superpower protectors could treat alliance security as a private rather than a collective good (Lee 2002: 119).

It can also be argued that nuclear weapons are more fungible than conventional forces, in that they remain relevant security assets in most cases, regardless of wholesale changes in future adversaries or contingencies. Indeed, programs that are developed under a veil of secrecy are often done out of existential deterrence, in that increased opacity often generates worst-case assessments that tend to err on the side of caution hence increasing first-strike uncertainty. Moreover, nuclear arsenals that are small, inaccurate, and countervalue-oriented, are usually indicative of a doctrine not based in nuclear conflict or second-strike capabilities.

In assessing possible reasons for the adoption of an existential deterrent policy by the 
DPRK, it is possible to cite a number of reasons. Most notably, and of primary concern, one can look to the issues directly related to South Korea, considering first the downfall of the Soviet Union, which served as the DPRK's chief Cold War patron against its rival in the South. Second, as a result of its opening a market economy, China sought diplomatic normalization with South Korea in 1992, disavowing its “as close as lips to teeth” security relationship with the North in the process (Cha 2002). Finally, as a final blow, Russia normalized relations with Seoul in September 1990, and declared that it would not honor Soviet cold war security guarantees to DPRK defense.

Thus, the period from 1989-1992, in which Gorbachev implemented GLASNOST and Perestroika, North Korea was left alone as a rogue state by its major allies. The political, economic, and military imbalance between the North and South provided the DPRK an impetus to produce nuclear weapons, for survival and for security. Moreover, the intensification of the DPRK's nuclear program provided the only alternative to guarantee North Korea’s own style of socialism, and indeed, to ensure the continuation of Kim Il Sung's dynasty (Suh and Lee 1998). Another issue has been the recurring failure of American and South Korean analysts in accurately perceiving and assessing Pyongyang's behavior. In late 1993, for example, there was an outbreak of media reports of a military buildup in North Korea, tests of new ballistic missiles, a tripling in frequency of fighter training exercises, and the movement of heavy artillery and multiple-rocket launchers closer to the Demilitarized Zone. Unnamed US officials speculated that the buildup was being undertaken because NK was planning an invasion of the South. Moreover, the possibility that the North's actions were defensive in nature was not considered (Mack 1994: 26).

While there is no evidence to date suggesting that the United States and South Korea 
have aggressive designs against North Korea, it is possible to understand the rhetoric as being intended to pressure North Korea to abandon its nuclear program, or to warn it of the costly consequences of military adventurism. Yet, these misperceptions were detrimental to existing tensions, as, from Pyongyang’s perspective, much of the American and South Korean reactionary rhetoric was viewed as threatening, fuelling both North Korea’s paranoia, and its determination to continue developing a nuclear program at all costs.

Although the nuclear proliferation motivations discussed above-political, technological, military and economic powers; struggle for identity, status competition, and security fears-have been described separately, they are interrelated in various ways, depending on the social and political context under which they are being examined. Indeed, these pressures in obtaining nuclear weapons are a result of strategic, foreign policy, and internal political and economic factors; and situational variables determine which motives will be active in a particular context and which specific courses of action will be chosen (Wessels 1995).

Due to the highly secretive nature of the DPRK, it is difficult to discern with precise accuracy its motivation for nuclear proliferation. As shown earlier in this section, the North Korean case exemplifies the very high levels of threat and risk associated with nuclear proliferation, and it also raises difficult questions about the most effective means of halting continued proliferation. Although North Korea may see nuclear weapons primarily as a means of deterring attack by the United States and South Korea (Mack 1994), it is possible that the state also sees nuclear weapons as a means of achieving greater regional power or as a bargaining chip for extracting concessions from the United States. Whatever the case, the intense desire of the DPRK to obtain and develop nuclear weapons heightens security fears and encourages the perception that North Korea needs nuclear weapons to protect itself from known and hostile 
adversaries.

\section{Kim Il Sung and Kim Jong II}

There appears to be some consensus among North Korea experts that the primary agents in understanding the intentions behind the nuclear program are the leadership roles of Kim Il Sung and Kim Jong II. $^{8}$ Initiatives and ideas with regard to the program belonged to the two Kim’s, and were disseminated sparingly among a small circle of advisers; moreover, these views were never recorded in any of both Kim's military writings. In spite of this, there is no denying that the DPRK's late leader, Kim II Sung, from very early on, appreciated the awesome destructiveness and deterrent value of the weapon, particularly as a young guerrilla fighter who witnessed the United States subdue the Japanese with a mere two of these weapons (Mansourov 1995). The same can be said of Kim Jong-Il, who, upon being educated in Russia, entered the Korean Worker’s Party (KWP) instead of joining the military service, and was reportedly being groomed from an early age to succeed his father, Kim Il-sung (Oh and Hassig 2000). Indeed, the “cult of Kim Jong-Il” is relentlessly promoted throughout the country as a benevolent father figure, but the picture outsiders have is an enigmatic, ruthless, and powerful tyrant (International Crisis Group, 2003: 2).

In an attempt to explain the logic of Kim, Mansourov (1995) presupposes that Kim Il Sung granted top priority to deterrence when assessing the use of nuclear arms in the overall military doctrine of the DPRK. The policy implications of an existential deterrent interpretation of DPRK strategic doctrine favor arguments for engagement. The logic of this policy by two Kims would be that a security dilemma operates with regard to DPRK weaponization. Although

\footnotetext{
${ }^{8}$ See Suh and Lee (1998) for a comprehensive discussion of the influence of the Kims on North Korean foreign policies. Suh and Lee describe Kim Jong Il, "the great leader," and an "enigmatic man”, while Kim Il Sung is described as the supreme leader.
} 
provocative by violating nonproliferation norms and couched in aggressive rhetoric, this weaponization is largely defensively intended. Moreover, the nuclear program is best ended by the guarantee of regime survival, not by pressure (Suh and Lee 1998).

It is thus of little surprise that the relationship between North Korea and the surrounding East Asian community can be characterized as fraught with anxiety. It is no exaggeration to acknowledge that North Korea possesses the capability to not only to upset stability on the Korean Peninsula, but also to destabilize the entire Asia-Pacific area. Indeed, an armed North Korea with nuclear capabilities would begin a dangerous process of nuclear proliferation and trigger a regional arms race, while at the same time wholly undermine the considerable stability and unprecedented prosperity that the Northeast Asian region has become accustomed to for decades. Moreover, this would undoubtedly have a dramatic impact upon the world economy and international relations more broadly, especially the unstable position in which it would place China, Japan, Russia, and the United States (Haass 1995).

\section{Overview of US Policies and Politics on North Korea}

Obviously, the discovery that the DPRK has active nuclear weapons program in violation of both its 1994 agreement with the United States, as well as its signature on the NPT, has become a major problem for the United States and its regional allies, South Korea and Japan. North Korea's announcement on January 10, 2003 of its intention to withdraw from the NPT will have serious implications for international arms control. The nuclear crisis on the Korean peninsula also raises questions about the United States commitment to the NPT.

In pursuing the objectives of deterring rogue states, the United States has relied largely on policies that isolate or punish the offending rogue states (O'Sullivan 2000: 56). Punitive tools, such as the use of military force, covert action, and the strengthening of a regime's neighbors or 
rivals, have sporadically played important roles in America's quest to marginalize or replace rogue regimes.

Thus, as North Korea’s nuclear activities increased during the late 1980s and early 1990s, the US intelligence community devoted growing attention to Pyongyang's nuclear weapons potential. This judgment was reaffirmed in all unclassified intelligence assessments throughout the latter half of the 1990s, up to intelligence reporting in mid-2001. Although the Central Intelligence Agency (CIA) assessment was widely interpreted as evidence that North Korea had one or two nuclear weapons in its possession, neither the intelligence community, nor any senior US official offered a definitive statement to this effect during the remainder of the 1990s. However, the intelligence community assessment shifted noticeably in December 2001, when an unclassified version of a National Intelligence Estimate (NIE) asserted that the Intelligence Community judged in the mid-1990s that NK had definitely produced one, and possibly two, nuclear weapons (National Intelligence Council, 2003).

In addition, the US intelligence community concluded, in the summer of 2002, that North Korea had undertaken a covert uranium-enrichment program, most likely initiated in the late 1990s (CIA Report to the US Congress 2002). According to the CIA, activities associated with this program surfaced definitively during 2001, and included extensive purchases of materials for construction of a gas-centrifuge enrichment facility. Though the CIA contended in November 2002 that the facility was at least three years from becoming operational, intelligence analysts believed that a completed facility could ultimately produce sufficient fissile material for two or more nuclear weapons per year (Warrick 2002: A1). In the CIA’s judgment, an enrichment facility would provide the North an alternative source of fissile material to substitute for the plutonium reprocessing activities that had become frozen under the Agreed Framework. 
Moreover, the November 2002 intelligence estimate did not preclude the possibility of Pyongyang's reactivating its plutonium separation program.

More than six months after the revelation that North Korea had undertaken a covert uranium-enrichment program, the first steps towards a negotiated solution began to take place in the form of trilateral talks between the United States, the DPRK, and China. Held in Beijing on April 23-25, 2003, the talks overcame strong opposition from the United States, who favored multilateral talks, as well as equally strong opposition from the DPRK, who favored bilateral talks. The compromise solution, while a significant achievement in itself, did not confirm a secure path to a negotiated resolution of the crisis.

Traditionally, when the use of carrots proves to be ineffective, the United States attempts to apply sticks, through the denial of financial aid, economic assistance, military cooperation, and technology access (Amini 2002: 8). However, the application of these sanctions incurs its own risk, as they endanger political relations and are frequently viewed as being controversial. Indeed, for example, one can look to the sanctions that were leveled against India and Pakistan, but failed to prevent those countries from deploying nuclear weapons. Moreover, the sanctions were lifted in the aftermath of the September 11 attack to support anti-terrorism action in Afghanistan (Shaikh 2002: 29-48).

Critics of the Clinton Administration claimed that the DPRK successfully manipulated the United States into easing long-standing restrictions, without providing the United States sufficient gains or guarantees in return (Weinberger 1999: 42). Others considered this a successful example of the application of economic pressure by the US (Koch 1999: 21), in that sanctions, while not terribly effective in the traditional sense, provided the United States with an additional bargaining chip to deal with the unpredictable and dangerous DPRK. It is further 
argued that this leverage has allowed the United States to continue a policy of containment and appeasement, thus keeping the crisis on the Korean peninsula from erupting into a large-scale conflict.

The Six-power Talks has been the Bush administration's alternative to the Agreed Framework. As of June 2004, the six parties (North Korea, the United States, South Korea, Japan, China, and Russia), had conducted three rounds of meetings. In each meeting, it is observed that the talks centered on the United States and North Korea. Thus, while it was considered a multilateral, it turned out to be a bi-multilateral negotiation, especially as North Korea has rejected any format but direct bilateral talks with the United States. While there is little doubt that this position is due to fears of being ganged up on, it is also important to consider that the North Korean assessment finds that it is the United States that has the real power to make or break any agreement about the Korean peninsula. The agreement to hold six party talks provides a significant benchmark for each of the countries that has an interest in the nuclear problem, and their ability to gather and hold serious discussions is essential for any peaceful and diplomatic solution to North Korea’s nuclear development problem.

\section{US Congress Constraints}

The division of powers between the President and the Congress in making foreign policies is one of the most widely debated issues in the constitutional law of US foreign policy (Smith 1998: 36). ${ }^{9}$ Many scholars have debated this issue from a legal perspective, arguing

\footnotetext{
${ }^{9}$ Smith's article, "Congress, the President, and the Use of Military Force: Cooperation or Conflict in the Post-Cold War Era?," focuses on the behavior of the President and the Congress regarding the shaping of foreign policies. Specifically, Smith tackles the issue on the use of force in addressing international problems such as the North Korean nuclear crisis. According to Smith, The debates on the proper role of military forces in the American foreign policy seem to have intensified the belligerent attitude on the part of Congress (37). See also Dahl (1964). Dahl offers a comprehensive discussion of the role of the Congress in the making of American foreign policy. In the book, "Congress and Foreign Policy," Dahl describes a pattern of policy-making by examining obstacles on the road to reason and reducing these obstacles, the relationship between party responsibility and foreign policy, and the problem of agreement.
} 
whether it is the president or the Congress that possesses the ultimate right to control the use of American force (Eagleton 1974; Reveley 1981; Wormuth and Firmage 1989). The limitation is that the conflict of the US Congress and the US President presents little opportunity to gain knowledge about the factors that might encourage cooperation or conflict during real decisionmaking situations (Hagan and Hermann 2001). Nevertheless, studying the conflict becomes especially important in making foreign policy.

Since the Vietnam War, the US Congress has shown itself to be a more assertive actor in foreign policy (Katzman 1990; Forsythe and Hendrickson 1996) although it has never successfully used the War Powers Resolution (WPR) to prevent a military action (Burgin 1992: 217). In order to be credible, threats, like promises, must be ratified via domestic processes, and to the extent that Congress influences - whether tacitly or explicitly - the ratification process, and thus the international bargaining power of the president.

Since presidents tend to dominate decision making over the use of force, the North Korean attention should also focus on the response of the Congress (Lian and Oneal 1993: 277300). This is because the Congress largely influences the general public in relation to their attitudes toward the president's actions. The Congress has the potential to divide the nation. For example, in his recent study of congressional responses to military intervention between 1973 and 1990, James Meernik found that a divided government is the most important predictor of a congressional response to the use or threat of force (Meernik 1995: 377-392).

Thus, it can be surmised that Congressional votes on questionable cases of military intervention - those that are not precipitated by a direct attack on US territory or allies — are somewhat peculiar. On the one hand, they are clearly viewed as votes of conscience by members of Congress and other insiders. It is apparently quite inappropriate to use logrolling tactics or to 
rely on the party whip to impose discipline when members decide to support or oppose the president's use of military force. Superficially, the question of risking American lives is considered a grave, highly personal matter, one not subject to the usual legislative battles or bargains over policy (Congressional Quarterly Weekly Report 49 nos. 1 and 2: 7, 66).

The success of Executive-Legislative relations in military and policy-making decisions on North Korea is crucial in the success of the United States to resolve the North Korean crisis. In the past twenty years, the United States has moved from something of an imperial presidency to more of an imperial Congress (Schlesinger 1973; Jones and Marini 1988), and finally to a rough stalemate between the two institutions today a situation in which each side depends on the other when committing the United States to a major military operation such as the case of North Korea). Ideally, the president provides energy and expediency in ordering forces overseas, acts as the highest level of the chain of command when forces are actually engaged, and serves as the focal point for the US interests on the world stage, while Congress serves as a forum for the intensive deliberation and debate that necessarily accompany important questions of national policy and provides the political support to US forces when they are sent in harm's way. This division of labor had become a major point of contention during periods of divided government such as in the policy of the United States on North Korea.

\section{The American Political Culture and the Public}

It can be argued that the political culture of Americans can best be characterized by their democratic traditions (Almond 1960; Jentleson 1992). ${ }^{10}$ In a democracy, policy makers contemplating the deployment of troops into a situation that is already hostile, or might become

\footnotetext{
${ }^{10}$ For a discussion on the role of public opinion in the shaping of US foreign policies, see Cook, Manza, and Page (2002) and Wittkopf (1990). According to Chambers and Goidel (2004: 31), although the public is supportive of an activist foreign policy, public opinion after the Cold War era has discouraged presidents from devising a broad, architectural foreign policy.
} 
so, should sensibly evaluate three considerations insofar as they desire support for the action from the public. First, they must consider the value the public places in the venture, and they may try to use whatever persuasive skills they possess to enhance this value- that is, to sell the project to the public. Second, they must consider the likely and realistic costs of the venture, particularly in American battle deaths. And third, they must evaluate the potential for the political opposition to exploit the situation, should battle deaths surpass those considered tolerable by the public (Hagan 1993; Jentleson 1992; Larson 1996; 1999: 624-627).

Following the Second World War, most Americans were uninformed and uninterested about international issues; their views were disproportionately shaped by domestic conditions rather than by adherence to coherent world-views (Hagan 1993; Hagan 2004; Kelleher, 1994: 26). Similar to people in other democratic countries at the time, Americans were generally slow to relate to foreign affairs and were generally noninterventionist. However, since the end of the Cold War, American public attitudes toward many countries have changed, and the American public has become increasingly well-informed about global issues, is interested in current international events, and is more opinionated than before with regard to major foreign and defense policy questions. In addition, the American public now considers moral and ethical issues when evaluating foreign policy choices, and is more pragmatic in showing support or opposition for overseas initiatives, including the use of force (Kelleher 1994).

To illustrate, in a September 1996 poll conducted by Program on International Policy Attitudes (PIPA) of the Center for International Security Studies at the University of Maryland, $68 \%$ rejected the argument that "we should go our own way in international matters not worrying too much about whether other countries agree with us or not." Moreover, about $60 \%$ range rejected the statement that "the US should mind its own business internationally and let other 
countries get along as best they can on their own." In a 1994 poll by the Times Mirror, 90\% agreed that "It's best for the future of our country to be active in world affairs.” In a June 1996 PIPA survey, 59\% agreed that “The end of the Cold War has unleashed new problems so that the world is still a dangerous place. Also, the US economy has become more interdependent with the world economy. Thus it is important for the United States to maintain vigorous diplomatic efforts." 11

When evaluating foreign policy decisions, a major factor that influences the American public's attitude toward the use of force is whether the military action is unilateral or multilateral in nature. Public opinion surveys indicate that the American public is more likely to advocate the use of military involvement when the United States is acting as part of a coalition, rather than when the United States is acting independently. Americans have often been somewhat more supportive when the country acts as part of UN-sanctioned initiatives. A 1992 Gallup Poll found that 87 percent of those surveyed agreed that the United States "should commit its troops only as part of a United Nations operation," while 73 percent felt that the United Statess should commit "only with other allies" (Kelleher 1994: 26). Finally, in addition to strong opposition towards providing foreign military aid overseas, the American public often refuses to support military assistance even to traditional allies, but instead, highly advocate humanitarian aid as the top international initiative. Americans consistently support nonmilitary international involvement, even though they continue to express reservations about a blanket intervention policy (Kelleher 1994: 26).

\footnotetext{
${ }^{11}$ See the online article by Steven Kull (1997), entitled, “Americans Have Not Turned Isolationist.” Retrieved from http://www.policyattitudes.org/noisoloped.html.
} 


\section{American Bureaucratic Politics}

Institutional factors, such as the US bureaucracy, have also provided limitations to US foreign policy. If the power debate between the executive and legislature can be considered as one hindrance, the bureaucratic nature of the US politics is also one factor (Hagan 1993). ${ }^{12}$ As the US Bureaucracy is likened to the US legal system (American Bar Association 1994), the national interest in issues such as truth or guilt/innocence in court is expected to emerge out of a clash of interests. As such, eliminating vested interests in the bureaucracy can be detrimental to sound policy making (American Bar Association 1994). Moreover, important national security or nonproliferation interests might be overlooked if there are no offices, agencies, or departments vested with the responsibility for such issues, and can be depended on to escalate those issues to higher levels of government, including the President himself, for decision (Hagan and Henman 2001).

Of the two premier foreign policy institutions, the State Department is primarily concerned with developing smooth relations with other countries, while the Defense Department is interested in maintaining alliance relationships and a defensive industrial base, including lower unit prices for its weapons systems through mass production resulting from exports. As a result, there is no single or specific institution that is primarily concerned with nonproliferation, or that can bring to the attention to the National Security Council (NSC) issues other agencies might

\footnotetext{
${ }^{12}$ Going beyond current academic preoccupation with the constraints imposed by bureaucratic politics, Francis Rourke (1972) examines the basic structure of power within which the US so largely shapes foreign policy. The classic on the subject of bureaucratic politics and US foreign policy is the work of Graham Allison. See specifically Allison's article on the Cuban Missile crisis (Allison 1969). For a detailed discussion of the impact of bureaucratic politics on US foreign policy on the North Korean nuclear crisis, see Sigal's (1998) book, Disarming Strangers: Nuclear Diplomacy with North Korea. According to Sigal, the complexity of addressing the crisis is built into the bureaucracy by statutes that govern the Executive Branch. In the Clinton Administration, the tasks involved in nonproliferation effort were divided among the Arms Control and Disarmament Agency, the Bureau of PoliticoMilitary Affairs in the State Department, and the office for nuclear security and counterproliferation in the Department of Defense (230).
} 
prefer to ignore for various bureaucratic reasons--and perhaps seek a Presidential decision if the issue is important enough (Weiss 1998; Karp 1996).

Yet another problem that has arisen following the end of the Cold War is that nonproliferation and arms control have failed to really become part of the centerpiece of national security strategy (Renmack and Shuey 1997). Instead, there has been a growing emphasis on counter-proliferation in the Defense Department, including the use of military forces to deter, combat, or defend against proliferation, as well as a recently renewed emphasis on anti-missile defenses following the North Korean test of a Taepo Dong missile.

\section{International Regime: The NPT and IAEA}

The backbone of the nonproliferation regime is the Nuclear Non-proliferation Treaty (Bunn1994: 52-60), itself the result of a concerted global recognition of the potential dangers of nuclear power. Under the NPT, states possessing nuclear weapons agreed not to transfer those weapons to non-nuclear states; in turn, non-nuclear states agreed not to receive, manufacture, or otherwise acquire nuclear weapons. Violators of the NPT are subject to economic sanctions (Litman 2003: 32). Thus, from its creation in 1968, the NPT has divided states into the nuclear "haves" and "have-nots" (Wessels 1995: 48). The current version of the NPT prohibits the acquisition of nuclear weapons, and contains provisions designed to limit their political role. Moreover, the NPT includes no-first-use pledges, and specific bans on the use of nuclear weapons against non-nuclear states.

To an extent not generally appreciated, the United States and the international regime of nonproliferation policies have had a fairly tight relation to NK (Sokolski 2001: 39-56, 2003). Under this interpretation of the NPT, adherence to the treaty required only minimal enforcement or monitoring. The key protection against proliferation, after all, was the willingness of nations 
to forswear exercising their natural right to acquire nuclear weapons in a legally binding treaty, meaning that the nonproliferation secured by the treaty was potentially quite fragile (Solski 2001, 2003).

However, from the mid-1990s, the NPT and its mutually assured destruction (MAD) inspired interpretation began to falter (Solski 2003). First, whatever limited utility MAD thinking may have had to describe or channel the Cold War competition between the Soviet and United States-led alliances, it was a tolerable view only so long as the two superpowers actively kept nations under their influence from acquiring nuclear weapons of their own. Indeed, during the Cold War, to a large extent, this worked. Second, following the end of the Cold War several NPT members exploited the generous nuclear compensation that a MAD-inspired view of the NPT required (Albright, Berjkout and Walker 1997: 290). North Korea, which became a member of the NPT in 1985, managed to secure all the nuclear assistance it needed in order to generate and separate plutonium for bombs, and launch a covert uranium enrichment program.

Third, although it only allowed the IAEA to inspect its facilities in 1992, Pyongyang was able to remain a member of the NPT even after it was found in violation of its safeguards agreement in 1993 and, indeed, even after it first claimed it had already withdrawn in early 2003 (Albright, Berjkout and Walker 1997: 65-67). Lastly, after the Cold War, enforcement of the NPT was tested and found wanting (Hibbs 2003). North Korea’s ability to evade the NPT requirement that it allow inspections of its facilities 18 months after signing, with no effective repercussions when their violations were discovered by the U.N. in 1993, underscores the wanting nature of the NPT following the end of the Cold War.

Evidently, the incentives which once led Iraq to renounce nuclear weapons and adhere to the NPT did not suffice to make it respect the obligations under the treaty. The incentives 
provided to North Korea to close its declared nuclear power program, including the reprocessing plant, have consisted not in threatening sticks, but in two remarkable carrots. Namely, (1) assistance in the procurement and construction of two light water reactors, and (2) deliveries of oil. Although this arrangement, and the agreed framework that formalized it, have been criticized by some as an unacceptable reward for North Korea's violation of its safeguards agreement, the unorthodox approach has been blessed by the Security Council, and the IAEA was requested to monitor the freezing of the declared nuclear program.

Although it was generally agreed that the NPT had succeeded in establishing a norm against nuclear proliferation (Bunn 1994), many of its shortcomings are becoming more and more visible. The first problem is ascribed to its discriminatory nature-dividing the world into nuclear weapons haves and have-nots — which has triggered charges of a double standard and has generated strong feelings of anger, resentment, and paternalism, particularly among developing nations, which have refused to sign the NPT (Aaronson 1992). A second problem is the failure of the nuclear weapons states to live up to "pursue negotiations in good faith on effective measures relating to cessation of the nuclear arms race at an early date and to nuclear disarmament, and on a treaty on general and complete disarmament under strict and effective international control" (Arms Control and Disarmament Agreements 1990: 100). In addition, nuclear weapons states have allowed global nuclear arsenals to grow to over 50,000 weapons by the mid-1980s (Sivard, 1991: 18).

Non-nuclear states have also charged that the failure of the nuclear powers to endorse CTBT is a matter of bad faith (Bunn 1994), and pointing towards a double standard of nonnuclear weapons states being asked to live up to the NPT provisions when nuclear weapons states have not held to their end (Wessels 1995). Finally, the fact that some known nuclear 
weapons states remain outside the NPT invites negative and paranoid perceptions - that a refusal to sign the NPT indicates an intention to build a nuclear arsenal. Yet, while this can increase tensions, it also helps to encourage leaders to believe that their national interests are best served by building a credible nuclear deterrent (Wessels 1995).

As dictated by the NPT, each member state is required to accept the IAEA safeguards system, which is designed to prevent cheating and clandestine production of nuclear materials. The overarching goal for the architects of the IAEA safeguards was to create a confidence through verification system by which governments did not misuse declared nuclear installations to divert fissionable material from peaceful to military purposes. As such, the IAEA has been an important component as an international regime in gathering intelligence on North Korea. First, the North Korean case demonstrates the value of modern techniques in chemical analysis, which have allowed the IAEA to conclude that North Korea had pursued more than the one reprocessing campaign, which it had declared, and that it must have produced more plutonium than it had originally stated. Moreover, the findings of the IAEA had been instrumental in showing a clear violation of the safeguards agreement under the NPT, though was inconclusive as to whether the non-declared nuclear material had been diverted for military purposes.

In rapid succession from December 2002 to January 2003, North Korea announced its intention to restart its long idle nuclear reactors, began to access materials and equipment that had been sealed and tagged by the IAEA to prevent their use, dismantled IAEA surveillance cameras at its nuclear facilities, and expelled IAEA inspectors from the country. On January 10, 2003, as the Bush administration was mired in fruitless diplomacy over Iraq at the UN, North Korea declared its official withdrawal from the NPT, and hence its rejection of the commitment to remain non-nuclear. In late January 2003, it was reported that Pyongyang had begun to move 
its 8,000 spent nuclear fuel rods out of storage facilities formerly safeguarded by the IAEA, raising concerns that it was about to begin reprocessing in order to extract the plutonium necessary for making nuclear weapons (Miller 2003: 83-84).

An essential part for the success of the nonproliferation regime is the confidence in the IAEA restraints, as perceptions of noncompliance, particularly of clandestine cheating, evoke strong security fears. The Iraqi case, for example, shook this confidence by showing that despite the IAEA safeguards, covert programs could advance far through the use of materials that had passed undetected through the extant safeguards system (Leventhal 1992: 167-180), and left little doubt that a determined proliferator could cheat successfully, even under full-scope IAEA safeguards (Scheinman 1992: 37-50). Moreover, this only reinforced serious doubts about the effectiveness of the system, and stimulated fears that other nations might develop covert nuclear programs (J. Deutsch 1992: 120-134). These fears were particularly heightened when inspections in, 1993, provided evidence that North Korea was developing a clandestine nuclear program.

Overall, despite the initiatives by the international community towards strengthening the safeguards and verification system, it is unrealistic to expect the system to be flawless (Bailey 1993). Moreover, even if cheating is detected, it is unclear how the international community will stop it. China, for example, had reservations about imposing sanctions on North Korea. With this case, thorny issues remain over how to insure compliance with IAEA safeguards.

\section{International Systemic Relations}

United States policies on North Korea are also influenced by the position of other actors in the East Asia international system. ${ }^{13}$ North Korea, and countries such as the United States, South Korea, Japan, Russia, and China, have different concerns for reducing tensions and for

\footnotetext{
${ }^{13}$ For an explanation of international systems theory, see Byers (1999), Doyle and Ikenberry (1997), Kowert, Kubálková, and Onuf (1998), and Mearsheimer (1990, 2001).
} 
establishing a peaceful regime on the Korean peninsula. South Korea wants to resolve the issue of separated family and inter-Korean economic cooperation first, while a resolution of the DPRK's nuclear programs comes only as a second priority. The DPRK wants otherwise: it wants to resolve arms control first, then the transformation of the truce agreement into a peace regime, and finally, the DPRK hopes to resolve the inter-Korean economic cooperation and the separated family issue, excluding the discussion on nuclear and missile issues. Some observers, however, believe that North Korea could change its priorities because they desperately need foreign economic support.

On the other hand, while the Bush Administration and the Japanese Government concentrate on resolving the North Korea’s nuclear development programs, they are sidetracking the communist country's calls for the withdrawal of US troops (Bosworth 2000: 54). Moreover, the Chinese Government is pushing towards a stable Korean peninsula without American or Japanese interventions; instead it advocates the autonomous efforts of the North and the South, a perspective that has brought alarm to the Bush Administration. For one, if autonomous efforts are carried out, there is a high possibility that the negotiating power of the United States might be weakened: the North might junk United States-led intervention in favor of that of South Korea due to its large-scale economic support to the North. However, the Bush Administration remains confident that the DPRK will need the support of Washington in obtaining foreign debt from the International Monetary Fund and the World Bank, which are largely controlled by the United States.

If South Korea rushes the withdrawal of American troops in the South, US foreign policy on the Korean peninsula and in Northeast Asia would be seriously damaged. As a result, the United States-South Korea cooperation could be destroyed. While the United States fears that the 
Chinese Government's proposal of autonomous initiatives on the North and the South, it is confident about South Korea's diplomatic ability in dealing with the North Korean issues successfully. It is the U.S. belief that in the end, the United States-South Korean cooperation will continue despite the complicated and delicate situation.

Another relevant issue that affects broader international relations is the national missile defense (NMD) system developed by the United States, and pushed by the Bush administration, and strongly opposed by China and Russia. Despite North Korean promises to end its missile program, the circumstances surrounding the Korean peninsula seem to have become further complicated, in that the US is arguing the necessity of the NMD system against the threat of missile attack from North Korea. Russian President Vladimir Putin's visit to Pyongyang in 2000 was largely suspected as a plan to cooperate with Pyongyang against the NMD system. Therefore, the NMD system has become a hot issue which could cause conflicts between the US and China, or Russia, and may also have an impact on the inter-Korean issues.

\section{Clinton and Bush Administrations’ Non-Proliferation Policy}

The similarities between the domestic constraints consisting of the US Congress, the American political culture and public opinion and bureaucratic politics and the systemic constraints such as the lack of cooperation/policy differences with South Korea, Japan, China and Russia and the nature of the two Kim regimes, have led to a convergence of Clinton and Bush administrations policies. Moreover, these constraints can be measured in the policy approach of bilateralism versus multilateralism, carrots versus sticks, and the use economic, military and diplomatic means and the utilization of the international regime such as the NPT and IAEA.

Early in his first term, President Clinton grappled with the North’s renegade nuclear 
weapons program. After many months of tedious negotiations with the North, the first-ever USNorth Korea political agreement, the Agreed Framework, was signed in October 1994, offering benefits to the North that included improved trade and political ties with Washington, a \$50 million-per-year fuel and oil supply, and construction of two light-water nuclear reactors valued at about \$5 billion. Together with a consortium of about a dozen nations, the United States began raising funds to support this process, with South Korea pledging to pick up most of the tab. In return, North Korea agreed to "freeze” its current nuclear program, preventing it from processing any more weapons-grade plutonium than it already possessed.

When Bush assumed office in January 2001, he quickly and deliberately distanced his administration from the engagement policy with North Korea that the Clinton administration had employed (Feffer 2002: 2-5; Cha 2002), and, instead froze talks with Pyongyang. However, the effectiveness of this hard-line approach began to wane as the DPKR continued to disregard the United States threat to impose sanctions on them. Thus, the Bush administration slowly started to open its communications door with North Korea, and resume talks and diplomatic negotiations. This gradual step back towards the Clinton administration's policy of engagement however, was rudely interrupted when the United States was attacked on September 11, 2001, and Bush’s statement during a State of the Union address shortly after in which he labeled North Korea as part of a three-country axis of evil.

The 9/11 episode propelled the Bush administration to pressure North Korea so that the diplomatic negotiations would resume. While North Korea insisted on bilateral talks, much like those they maintained with the Clinton administration, Bush was pushing for a multilateral negotiation that included major regional players such as South Korea, Japan, Russia, and China. It is argued that the Clinton administration could have resolved the North Korean nuclear 
threat, had it not been for domestic constraints during the national election noting especially the Florida fiasco, that ultimately halted negotiations between the two leaders (Ferrer 2002: 2). Upon assuming the presidency, Bush ordered a full review of the Clinton administration's policy on North Korea, and then halted the policy of engagement, and ultimately damned the Sunshine Policy (Ferrer, 2002: 3), suggesting that North Korea had violated its agreements with the United States. The former South Korean president Kim Dae Jung’s Sunshine Policy rested on the engagement premises where South Korea would maintain economic relations with North Korea.

Though the hard line policy of the Bush administration forced North Korea to pull away from the negotiation table, North Korea continued to maintain a moratorium on missile launches that it had declared in 1999, and continued to abide by the Agreed Framework.

\section{Clinton Policy and Implementation Strategies}

The Clinton administration advocated for a policy of engagement using a bilateral type of negotiation, carrots using economic incentives through economic and diplomatic means and the exclusion of the international regime though it has utilized the international regime in the first part of the regime. The policy of engagement implemented by the Clinton administration resulted to the success of getting the Agreed Framework. ${ }^{14}$

At the onset, the Clinton administration inherited a rigid policy from the first Bush administration, which rested on the premise that North Korea would not be allowed to produce any nuclear weapons. According to Sigal (1998), by publicly stating that his aim was to deny North Korea even one nuclear warhead, Clinton defined the problem in a way that resisted solution. Moreover, in an attempt to deter the North Korean nuclear proliferation, the Clinton

\footnotetext{
14 The following general sources were used in this study to construct Clinton Foreign policy: Berry (1995), Bosworth (1995), Cronin (1994), Feffer (2002), Hagan (2004), Juster (2000), Kim (1998), Koch (1999), Litwak (2000), Mearsheimer (1990), Miller (2003), Pilat (1994), Sanger (1993, 1994), Sigal (1998, 2000), Sokolski (1995), Suh and Lee (1998), and Williamson (1999).
} 
Administration began applying the economic sanction strategy, in an attempt to destabilize and manipulate the current regime, a strategy that had been predominant in United States policy orientation towards North Korea. However, these sanctions proved to be largely ineffective in stopping the DPRK from developing an advanced rocketry program and the potential for nuclear weapons. In August 1998, the DPRK tested a rocket over Japan, alarming neighboring nations and the United States (Weinberger 1999: 42), and precipitating policy concerns in South Korea, China, Japan and Russia. South Korea in particular adapted the Sunshine Policy in its relations with North Korea. Following discussions between representatives from the two adversarial nations, a compromise was reached, in which North Korea promised to suspend testing of its missile program in return for a promise by the United States to relax its embargo against the DPRK (Koch 1999: 21).

The implementation of the Agreed Framework rested mainly on the principle that North Korea would comply with the agreement. While critics of the Clinton Administration's concessions claim that the DPRK manipulated the United States into easing long-standing restrictions without sufficient gains or guarantees in return (Weinberger 1999: 42), while others considered it a successful example of the application of economic pressure by the United States (Koch 1999: 21). The Agreed Framework was the only signed agreement that sought resolution of the North Korean-United States problem, and can arguably be viewed as one of the greatest achievements of the Clinton Administration, as it worked to calm the nuclear threat from the DPRK for some time. According to Suh and Lee (1998), Olsen (1996) and Sigal (1998, 2000), the Agreed Framework was a triumph on the policy and security term after years of negotiation with North Korea. In signing the Agreed Framework, North Korea agreed to shut down its nuclear reactors, freeze its nuclear activities, and put its nuclear assets under IAEA inspection 
(Miller 2003: 83-84). In return, North Korea received a pledge that a consortium of outside powers would provide the country large shipments of oil.

Though plagued with problems including implementation delays and mutual recriminations, the Agreed Framework succeeded in freezing North Korea's plutonium program for nearly 10 years (Miller 2003; Sigal1998, 2000; Olsen 1996; Suh and Lee 1998), and, at the very least, established communication and engagement between the powers. The Agreed Framework had several objectives covered, including: (1) the United States would endeavor to replace North Korea's graphite-moderated nuclear reactors with safer and more powerful Light Water Reactors (LWR), which are also more proliferation-resistant; (2) the working towards normalization of relations between the two countries; and (3) the agreement renewed North Korean dedication to the NPT a stable environment on the Korean peninsula (Suh and Lee, 1998). Finally, through the formation of the Korean Peninsula Energy Development Organization (KEDO), contact has been secured and cooperation enhanced between the participating members of the global community and North Korea.

However, despite the optimism showed by some scholars on the end of the nuclear threat in North Korea, the problems and constraints that ultimately led to the breakdown and failure of the Framework were visible (Sigal 1998, 2000). One major implication of the abruptness of actions from the collapse of the Agreed Framework is the absence of alternative arrangements to constrain North Korea's nuclear weapons potential. The absence of a viable policy alternative is one of the major constraints that the Bush administration faces. 


\section{Bush Policy and Implementation Strategy}

As previously stated, the Bush Administration’s policy toward North Korea has been a clear deviation from that of the Clinton administration. ${ }^{15}$ This deviation however was only true in the early period of the Bush administration, and became especially apparent after the September 11 attacks. The Bush administration has instead employed a multilateral approach, using a sanction-based strategy through military and economic means and the exclusion of the international regime. Thus, the bilateral negotiations between the United States and the North Korea that were formalized by the October 1994 Agreed Framework were changed to multilateral negotiations under the Bush Administration, and the Agreed Framework was replaced by the Six-Country Talks. Moreover, in the Six-Party Talks, the Bush administration insisted that the DPRK dismantle its nuclear weapons program prior to negotiations or the resumption of high-level exchanges between the two countries.

Moreover, following the September 11 attacks, an eminent preoccupation among policy makers in the Bush administration has been the war in Iraq and its fight against terrorism. Yet, Pyongyang has managed to keep the North Korean nuclear issue active through the dismantling of the Agreed Framework and the withdrawal of the DRPK from the NPT, thus severing all nuclear inspection arrangements with the IAEA. These developments point to the renewal in coming months of an acerbic debate that took place at the end of the Clinton administration over the merits of engaging or containing the DPRK. Although the Bush administration's initial review of North Korean policy in June 2001 recommended unconditional engagement with

\footnotetext{
${ }^{15}$ The following sources were used in this study to construct the Bush Foreign Policy on the North Korean nuclear crisis: Carlson (2003), Cha (2002), Choi (2003), Diehl (2002), Fein (2003), George W. Bush Administration Policy Toward North Korea (2004), Heginbotham (2003), Kerr (2003), Koh (2003), Koppel and Labbot (2001), LaMontagne (2002), Lee and Feffer (2004), Niksch (2003), Pollack (2001), Sherman (2002), Perry (2001), Conachy (2001), Gross (2001, 2001).
} 
Pyongyang on a broad range of issues including its suspected nuclear weapons program, ballistic missile production and export, and its conventional force posture on the peninsula, this position is far from a conclusive, given the well-known skepticism of North Korean intentions, as expressed in the Bush's axis of evil speech as well as other statements by administration officials.

A pertinent source of systemic constraint in the current administration is Bush's "axis of evil” speech (Cha 2002). The label is a result of the threat that these three countries pose on the United States and its allies. Observers, however, argue that the axis of evil speech created an imminent military action against North Korea (Cha, 2002: 82). However, White House officials had intimated a harder-line policy toward North Korea, much at odds with the Sunshine Policy of South Korea. Thus, the conflict involving the respective policies of South Korea and the United States places a critical constraint on the possibilities of negotiating a multilateral strategy, considering that the US government requires the cooperation of countries such as South Korea in the resolution of the North Korean crisis. Moreover, this disagreement has presented conflicts among the US and its allies in determining the most appropriate strategy for dealing with North Korea.

Critics assert that the stick strategy by Bush will not work. Instead, carrots, in the form of normalized political relations, economic aid and investment, and mutual tension reduction is the best option in reducing North Korea's insecurity, and offers a path towards reform for ending the proliferation threat and other belligerent DPRK behavior (Cha and Kang, 2003: 20). However, skeptics of an engagement policy do not believe that the regime's revisionist intentions will change, and argue that the offer of economic and diplomatic carrots only strengthens the hardliners in Pyongyang, exemplifies Western weakness (in DPRK eyes), and ultimately strengthens a regime bent on overturning the status quo on the peninsula. As Douglas Paal (2001: 
305) claims, engagement policy amounts to "conditional appeasement" and will not produce observable change for the better in the DPRK.

The very existence of a vigorous policy debate between Washington, Seoul, and Tokyo, indicates a fundamental absence of agreement on the nature of the threat posed by the DPRK. The Bush Administration, after the termination of the Agreed Framework, began working on a multilateral approach of negotiation with North Korea, and started to conduct six-country talks. Though originally opting for the continuation of bi-lateral talks, North Korea was left with no choice but join in the six-country talks. Indeed, this hard line policy approach by the Bush administration has been predicted by observers to continue (The Washington Times December 11, 2003; Erickson 2003; Associated Press 2004; BBC News 2004). For instance, regardless of the timing of the security guarantee, the United States will continue to put the screws to Pyongyang (The Washington Times December 11, 2003), and the Proliferation Security Initiative (PSI), which is designed to identify and seize materials related to non-conventional weapons, is targeted directly at North Korea's exports and is in full force, according to several administration officials.

The language in the statement of principles - only opposed by China - is vague on the specifics of a security guarantee, and is, in part, a reflection of the infighting within the administration on that very issue (The Washington Times December 11, 2003). The hard line option that has been included in the list of possible recommendations stipulates that the security guarantees will only follow "complete, verifiable, irreversible dismantling" of the nuclear program. But as long as the DPRK maintains even one civilian nuclear reactor - or refuses to grant complete, unfettered access to inspectors - such an exacting standard will probably not be achieved. 
China has been the host of the four rounds of the six-country talks. The initial reports and news on these multilateral talks were bleak. Modest expectations are almost a given when it comes to untangling the North Korean nuclear crisis. But even judged by these underwhelming standards, the multilateral talks in Beijing were less than successful insofar as the first few rounds of the talks were concerned (Erickson, 2003: 1). So far, diplomats from the United States, North Korea, China, Russia, South Korea and Japan left the six-sided bargaining table—custom built for the talks—offering few signs of progress. The North was miffed partly because the Unite States has continued to demand that North Korea give up its nukes as a prelude to further negotiations, without a reciprocal nonaggression treaty (Erickson 2003: 1).

\section{Towards a Nuclear-Weapon-Free World}

In summary, this chapter has suggested that the only guarantee against the threat of nuclear war is the complete elimination of nuclear weapons. The nuclear dilemma discussed in this chapter is this: the nuclear-weapons states will not give up their nuclear capability without first being convinced that their strategic dominance will not be challenged. But the threshold nuclear weapons states will not give up their nuclear option without seeing proof of a timetabled move towards a nuclear-free world. To achieve a nuclear-free world goals—deeper reductions in the nuclear arsenals of nuclear-weapons states, further constraints on the deployment of their nuclear weapons on the territories of other states, the entry into force of the CTBT, and the negotiation of a ban on missile test flights and on the production of fissile materials—must be satisfied.

In the following chapter, the Clinton Administration's policy towards North Korea, and how domestic and systemic factors affected his initial policy of bilateralism, carrot approach and inclusion of the international regime are presented. 


\section{CHAPTER III: SYSTEMIC AND DOMESTIC CONSTRAINTS IN CLINTON POLICY ON NORTH KOREA}

The previous chapter has shown the highly secretive nature of the North Korean regime, and the difficulty involved in discerning with accuracy its motivations for nuclear proliferation. More importantly, it also raises difficult questions about the most effective means of stopping nuclear proliferation. Although the DPRK has attempted to justify its development of nuclear weapons as a means to deter a possible attack by the United States and South Korea, it is highly possible that the state also seeks to achieve greater regional power. However, despite attempts by various world leaders to resolve the nuclear threat, the DPRK has since demanded bilateral negotiations with the United States because it needs to "establish a new, adequate-to-the-newinternational-situation relation between the North and the United States” (Bezlova 2001: 1). Also, Pyongyang views Washington as its counterpart in negotiating the stalemate on the Korean peninsula. As such, North Korea's desire to improve relations with the United States and the significance of Washington's success in curtailing Pyongyang's production and dissemination of WMD are some of the major motivations for bilateral talks (Han 2002: 104-105).

The Clinton Administration, concerned by the alarming North Korean nuclear threat, had placed it as one of the priorities of its foreign policy, and, from the outset, employed a bilateral approach in diplomatic negotiations, used economic incentives or carrots, and included the international regime. However, the domestic and systemic constraints that the administration faced - starting from the policy formulation until the implementation process - necessitated a change in the strategy and approach. In the end, although the Clinton administration maintained bilateral negotiations and the use of economic rewards, it used diplomatic and military measures 
and excluded the international regime. ${ }^{16}$

To a great extent, the increased engagement during this period was in response to North Korean actions, which triggered international concern over the growing nuclear and missile programs. Fearing that North Korea’s actions would irreparably damage the international nonproliferation regime, the Clinton Administration engaged in intensive negotiations with North Korea, which eventually yielded the 1994 Agreed Framework. However, the promise and the prospects of a resolution to the North Korean nuclear threat had already been seriously impeded by the domestic and systemic constraints. Indeed, the policy approach and strategies of the United States toward North Korea are dictated by the domestic and congressional concerns (Hagan, 2004).

Policy alternatives that are addressed and considered during debates in Congress (Sigal, 1998, 2000) are indicative of the diverging views among American policy makers. Regarding the North Korean nuclear crisis, these issues include the use of a multilateral or bilateral approach, economic sanctions, carrot versus stick strategy, and financial constraints and economic aid that the US bestows on North Korea. As such, this chapter illustrates the domestic and systemic constraints that the Clinton administration has struggled against, and argues that, because of these limitations and constraints the expectations on the Agreed Framework were not achieved, thus forcing the Clinton Administration to shift its policies and strategies.

The first section of this chapter illustrates the policy and strategy of the Clinton administration at the start of its term, and evaluates their rationale. The second section presents the systemic and domestic constraints that the initial policy and strategy of the Clinton

\footnotetext{
${ }^{16}$ It should be noted that a US policy of engagement toward NK did not originate with the Clinton administration. Both the Reagan and the Bush, Sr. administrations made limited efforts prior to Clinton taking office. The Clinton administration, however, was chosen for this study because it marked a significant expansion over the efforts of previous administrations in the level of US engagement with the DPRK.
} 
administration faced, such as the opposition from Congress, the lack of military power, and the public attitude of the United States towards North Korea. Moreover, the systemic constraints that will be addressed include the inability of the United States to form a solid coalition among its allies such as the four regional countries involved in six-party talks, as well as the role and attitudes of the Kim regime. The third section of the Chapter provides a discussion on the Agreed Framework, the problems that the United States encountered in the policy formulation including opposition and limitations, and the domestic and systemic constraints. This is followed by a section that evaluates the domestic and systemic constraints in implementing the Agreed Framework, as well as the framework's failure in resolving the North Korean crisis. Finally, the fifth section provides a synthesis of the chapter.

\section{Framework for Analysis}

This chapter takes a critical approach in evaluating the domestic and systemic constraints on the Clinton administration policy in dealing with the North Korean nuclear crisis. The analysis shall start with the policy formulation at the start of the Clinton administration, and the domestic and systemic problems they faced from the outset. The figure below (Fig. 1) shows the framework and analysis for this chapter, and suggests that the Clinton administration was besieged by both domestic and systemic constraints from the moment the administration started to formulate its policies and implementation strategies. Moreover, even from the decision to choose its policy instruments such as bilateralism, carrots, long-term plan and the use of political and economic constraints, the administration was hounded by domestic and systemic constraints. Similarly, the Agreed Framework was besieged by the same constraints. It thus follow that, in order for the United States to effectively resolve the North Korean nuclear threat, the domestic and systemic barriers must be minimized, if not entirely removed. The contribution of this study 
rests in the identification of the domestic and systemic constraints in the policy formulation and implementation process of the United States policy on North Korea.

Figure 1. Framework for Analysis (Clinton Administration)

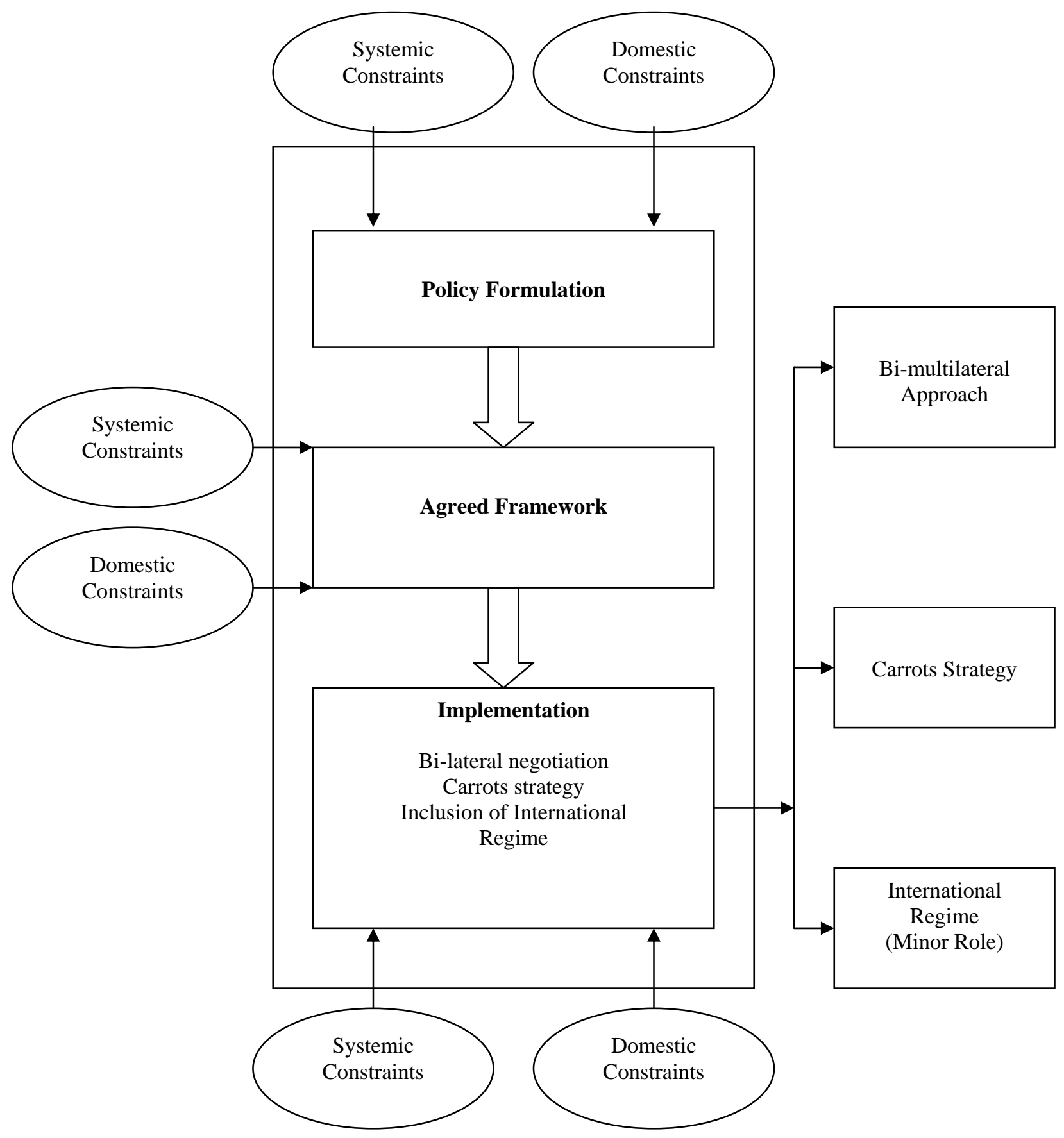




\section{Clinton's Initial Policy on North Korea ${ }^{17}$}

Clinton formally revealed his nonproliferation policy in a speech at the UN in New York, on September 27, 1993, affirming the top priority of nonproliferation in American foreign and national security policy. ${ }^{18}$ The policy initially included negotiating a Comprehensive Test Ban Treaty (CTBT), strengthening the Arms Control and Disarmament Agency (ACDA), creating specially tailored non-proliferation strategies for problem states (North Korea, Pakistan, Iraq), negotiating an international ban on the production of highly enriched uranium or plutonium for nuclear explosive purposes, and reforming US export controls in order to remove impediments for US exporters of high-tech goods (US Senate Committee on Governmental Affairs 1995). Specifically, Clinton’s policy was geared towards North Korea’s nuclear program, and involved several factors (Cronin, 1994: 5). Foremost of which was a consideration of the American domestic sphere (Hagan 2004), which includes a US Congress that would be ratifying and supplying the much needed financial and legislative back up of his policy, American public opinion because of the principle of accountability inherent in democratic institutions, and the bureaucracy, including the role of the State Department and the Defense Department in the implementation of its policies. Within the systemic sphere, Clinton had to take into account the existing international regime related to Nuclear Proliferation, such as the NPT, to which North Korea was a member, and the IAEA, as well as the differing foreign policies of major regional

\footnotetext{
${ }^{17}$ See the articles of Anthony (2000a, 200b), Cronin (1994), Destler (1998), Finnegan (1999), Juster (2000), Pilat (1994), and Wolfsthal (1993), and the books by Hagan (2004) Halberstam (2001), Rubinstein et al. (2000), Scott (1998), Sigal (1998).

${ }^{18}$ In his speech, Clinton states, "If we do not stem the proliferation of the world's deadliest weapons, no democracy can feel secure. If we do not strengthen the capacity to resolve conflict among and within nations, those conflicts will smother the birth of free institutions, threaten the development of entire regions, and continue to take innocent lives... One of our most urgent priorities must be attacking the proliferation of weapons of mass destruction...I have made nonproliferation one of our nation's highest priorities. We intend to weave it more deeply into the fabric of all of our relationships with the world's nations and institutions. We seek to build a world of increasing pressures for nonproliferation, but increasingly open trade and technology for those states that live by accepted international rules.”
} 
players, such as South Korea, Japan, China, Russia, and North Korea.

When Clinton assumed office in 1992, North Korea's nuclear arms development had already become the focus of intense international concern. Clinton's initial policy position was to freeze the nuclear weapon production of the DPRK, a posture that ultimately created a stand-off between the two countries until 1994. It was only in 1994 when bilateral talks opened between North Korea and the United States, between former US President Jimmy Carter and envoy Robert Galucci, and the DPRK. The Clinton administration's goal was to stop and prohibit North Korea to produce any nuclear weapons (Cronin 1994; Sigal 1998). From this premise, he devised his initial policy on North Korea that leaned on cooperation: proposing the use of diplomatic means of negotiation that took the form of bilateralism, the use of economic rewards evidenced in favorable trade conditions and foreign aids, and the inclusion of the international regime such as the utilization of the NPT and the IAEA (Wolfsthal 1993: 6-9; Finnegan 1999: 81-109; Pilat 1994: 275-290; Juster, 2000: 51-69).

Indeed, the Clinton Administration, from the very beginning, had emphasized the use of unilateral or bilateral talks with North Korea. Moreover, it used economic rewards, and sought the help of the NPT and the IAEA in its actions towards the DPRK. The three variables listed below—Clinton's bilateral approach, economic rewards and the use of economic and diplomatic means, and the international regime—-are the initial policy strategy that was used by the Clinton Administration in dealing with the North Korean nuclear threat. These variables in turn were hounded by domestic and systemic constraints that greatly influenced the initial strategy and approach of the Clinton Administration. 


\section{Table 1: The Road to the Agreed Framework}

\begin{tabular}{|c|c|}
\hline Date & Nuclear Standoff \\
\hline May 1992 & $\begin{array}{l}\text { IAEA initiates series of inspections to verify North Korea's inventory of } \\
\text { nuclear materials. The agency soon discovers plutonium production } \\
\text { discrepancies. }\end{array}$ \\
\hline March 11, 1993 & $\begin{array}{l}\text { North Korea withdrew from the NPT in a harsh rebuff of Western demands } \\
\text { to open suspected nuclear weapons development sites for inspection. It later } \\
\text { suspended its withdrawal. }\end{array}$ \\
\hline June 11, 1993 & $\begin{array}{l}\text { North Korea suspends its withdrawal from the NPT one day before it would } \\
\text { have taken effect, but asserts IAEA inspections of its nuclear facilities are } \\
\text { no longer feasible. }\end{array}$ \\
\hline July 10, 1993 & $\begin{array}{l}\text { Clinton traveled to South Korea, where in a speech to the National } \\
\text { Assembly he denounced communist North Korea for raising the specter of } \\
\text { "nuclear annihilation." }\end{array}$ \\
\hline May 30, 1994 & $\begin{array}{l}\text { The UN Security Council warned North Korea to stop refueling a nuclear } \\
\text { reactor and allow U.N. monitors to perform full inspections. }\end{array}$ \\
\hline June 2, 1994 & $\begin{array}{l}\text { Clinton decides to pursue sanctions against the North after receiving IAEA } \\
\text { assessments. North Korea prompted the measure by declaring it would never } \\
\text { allow IAEA inspection of two undeclared nuclear waste sites that would } \\
\text { determine past levels of plutonium production. }\end{array}$ \\
\hline June 11, 1994 & $\begin{array}{l}\text { The US, South Korea and Japan agreed to seek punitive steps against North } \\
\text { Korea over its nuclear program. }\end{array}$ \\
\hline June 13, 1994 & North Korea withdraws from the IAEA. \\
\hline June 16, 1994 & $\begin{array}{l}\text { Jimmy Carter, on a private visit to North Korea, reported the nation's leaders } \\
\text { were eager to resume talks with the US on resolving disputes about } \\
\text { Pyongyang's nuclear program and improving relations. }\end{array}$ \\
\hline June 18, 1994 & $\begin{array}{l}\text { The presidents of North Korea and South Korea agreed to hold a historic } \\
\text { summit. Plans were disrupted by the death of North Korean leader Kim Il } \\
\text { Sung on July } 8 \text {. }\end{array}$ \\
\hline October 21, 1994 & $\begin{array}{l}\text { The US and North Korea signed an agreement requiring the communist } \\
\text { nation to halt its nuclear program and agree to inspections. }\end{array}$ \\
\hline
\end{tabular}

Source: Carnegie Non-Proliferation Project: North Korea Nuclear and Missile Timeline, http://www.ceip.org/files/projects/npp/resources/koreatimeline.htm. 


\section{Clinton's Bilateral Strategy}

Initially, the Clinton Administration's demand that North Korea freeze its nuclear weapons production facilities merited an erring from the Kim Il Sung regime, and it was only in 1994 when the doors for bilateral negotiations opened. On June 15, 1994, Jimmy Carter successfully negotiated a deal with the DPRK, wherein Pyongyang finally confirmed its willingness to freeze its nuclear weapons program and resume high level talks with the United States. However, Clinton’s bilateral approach indicates a direct diplomatic negotiation with North Korea, with the exclusion of countries such as South Korea, Japan, China and Russia. Before higher-level talks had proceeded, Kim Il Sung died and was replaced by his son Kim Jong Il. Despite the change in the leadership of the North Korean regime, bilateral negotiations between Washington and Pyongyang resumed, and on August 13, 1994, preliminary agreement between the two countries was signed. Finally, following two additional months of bilateral talks between the United States and North Korea, the Agreed Framework was signed on October 21, 1994. Calling for movement toward a full normalization of political and economic relations, the accord also served as a jumping point for further United States-North Korean dialogue on Pyongyang's development and export of ballistic missiles. ${ }^{19}$

Clinton’s bilateralism was comprised of high-level talks that discussed the issues and concerns between the two countries, ranging from nuclear program issues, economics, politics and military use (Pilat 1994: 275-290; Sigal 2000; Juster 2000: 51-69; Mearsheimer 1990: 5-56). Through bilateralism, scholars, using Iraq as a case example for the success of bilateralism, suggested that it is the bilateral negotiations that the US has moderated rogue states' behavior and construct a positive bilateral relationship (Juster 2000: 51-69). Shirk (1997: 245-270)

\footnotetext{
${ }^{19}$ See Chronology of U.S.-North Korean Nuclear and Missile Diplomacy at http://www.armscontrol.org/factsheets/dprkchron.asp.
} 
supported this conclusion by asserting that maintaining a balance with the DPRK necessitates the US’ reaffirmation of its bilateral alliances and military presence in the region.

In support of bilateralism, scholars assert that although multilateral efforts, in terms of developing domestic and international support for nonproliferation actions and in reducing costs, are desirable in principle, they are not always possible (Pilat 1994: 275-290). This suggests that if needed, the capability to act alone is essential, and, therefore, a bilateral approach is ideal in order to gain support both from the domestic and the international arena. Moreover, policymakers turn to bilateral engagement when both economic sanctions and military force appear unattractive (Sigal 1998, 2000). The United States had campaigned ardently to secure backing from North Korea’s neighbors for the imposition of multilateral sanctions, but had achieved only limited success.

\section{Economic Rewards and the Use of Economic and Diplomatic Means}

The initial policy of the Clinton Administration had been grounded on the engagement policy, by which the administration worked on economic rewards for North Korean concessions, and bargained bilaterally through diplomatic means. The Agreed Framework contained provisions for economic support and favorable trade provisions for the DPRK. In turn, the state shall freeze its production of nuclear weapons. Theoretically, the bilateral relations between the two countries would gradually improve, and the bilateral negotiations resulting from the Agreed Framework characterized a landmark in Clinton’s legacy.

The key reward offered by the Clinton administration consisted of a commitment by the United States and its allies to ship fuel oil to North Korea, and to build proliferation resistant light-water reactors in the country so as to offset the power generation losses the North suffered by relinquishing its supposedly peaceful nuclear power program. Moreover, the United States 
and North Korea would reduce trade barriers and work towards the opening of liaison offices in each other's capitals. The assumptive gains of Clinton's carrots or rewards-based approach was that North Korea would be willing to conform to the Agreed Framework and any further negotiations that they might enter into with the US. For North Korea, nuclear weapons provided their principal bargaining chip, and were its key reciprocal tool for gaining certain political and economic rewards, whether these rewards are diplomatic recognition or light-water reactors. However, some scholars, favor the use of sticks as opposed to the use of carrots in negotiating with the DPRK (Berry 1995: 17). Indeed, the Clinton Administration’s tendency to use economic rewards has generated debates among scholars.

In concurrence with Clinton’s economic rewards strategy, Cha and Kang (2003) have illustrated why a carrot strategy serves as the best option for the United States to effectively implement a nuclear nonproliferation program. Their perspective views carrots as more worthwhile than sticks, and emphasizes the responsibility that the world's most powerful nation has in resolving conflicts through negotiations. Indeed, while those in Seoul favoring engagement agree that recent DPRK behavior represents tactical changes for the purpose of the regime's survival, they believe that such behavior in fact reflects a fundamental change in Pyongyang's intentions with further concessions by the North awaiting larger carrots from the West.

Moreover, the Clinton Administration had planned to use sticks strategy if carrots did not work. According to Robert Gallucci, the United States had planned to move ahead with efforts to have the UN adopt economic sanctions, despite warnings of the potential dangers involved with implementing a proactive stick strategy (Berry 1995: 17). Clinton had hoped that in refusing to offer a comprehensive deal to North Korea, the Chinese would see this offer as a reasonable 
effort to resolve this dispute and not veto a potential subsequent sanction resolution in the Security Council (Berry 1995: 18). After evaluating the stand of US officials on the use of an economic 'reward and sanction' strategy, the North Korean case suggests a balance between the two strategies, and the tone in which they are combined that makes all difference (Mazarr 1995: 208-209). The promise of benefits for nonproliferation, and the threat of punishment otherwise, must always be present in US policy.

There are some scholars who surmise that the use of economic rewards and sanctions are indeed complimentary. For instance, O’Hanlon and Mochizuki (2003) suggest that the use of both rewards and sanctions is not contradictory, and, as such, the outside world should not give Pyongyang substantial aid and other benefits simply to appease a dangerous leader or solve an immediate security crisis. However, if the DPRK is prepared to eliminate its nuclear weapons programs, transform the broader security situation on the peninsula, reform its economy, and begin the long process of changing its own society, outside countries can and should be generous in providing economic aid. Doing so would not be weakness; it would be a promising way to truly solve an important security problem by changing the fundamental nature of the adversary. If NK did not verifiably cooperate with this effort, the United States and its partners could then get tougher and use sticks (O’Hanlon and Mochizuki 2003: 43). In addition, O’Hanlon and Mochizuki (2003) called for a combination of "steaks and sledgehammers”, rather than the more traditional carrots and sticks (43). It is the stick strategy that a proposal of nuclear nonproliferation the DPRK cannot refuse. Indeed, US interests in the preservation of peace and stability will be best served by engagement, but engagement as a stabilizing factor, the balancing wheel (McLean, 1999). It can be argued here that in a messy and unstable world, the main idea seems to be to use both rewards and sanctions, to cajole as well as to encourage, in holding the 
sum of things together.

Yet, the inherent limitations of the economic reward strategy do not bear sole responsibility for the failure of Clinton administration's attempts at freezing North Korea's nuclear productions. For instance, Litwak (2000) has criticized the inconsistencies of the administration in its implementation of carrot and stick strategy. While the administration advocated the implementation of all carrot and no stick in its North Korea policy, it simultaneously condemned European countries in their own carrot strategies. As such, he proposes that the best option between stick and carrot is still the combination of the two (Litwak, 2000), though the more dominant strategy, he argues, should be the stick, especially on countries that are considered as rogue states such as the DPRK.

\section{The International Regime: NPT and IAEA}

The Clinton administration was a strong supporter of the international nonproliferation regime, which is made up of treaties, international organizations, multilateral and bilateral agreements, and unilateral actions, each intended to prevent further proliferation (CRS Issue Brief 91141; CRS Issue Brief 92056). The major components of the international regime include (1) NPT, which has 180 member states, commits non-nuclear weapons members not to acquire or make them, and allows for international inspections of all nuclear activities, and (2) the IAEA, which was established in Vienna in 1957, and verifies the peaceful use of nuclear materials; and (3) other actors such as international export control regimes (CRS Issue Brief 4054).

The NPT and the IAEA have played very crucial roles in the detection of nuclear weapons, and, more specifically, in attempting to contain North Korea’s nuclear program. Yet, while the international regime to which they belong represents one of the more significant sources of measure in enforcing the policies of the Clinton administration, it can also be a source 
of constraints. For instance, the Clinton administration used the IAEA and the NPT to inspect undeclared nuclear sites in North Korea, though it had not demanded such inspections for any other country. ${ }^{20}$ The IAEA took this posture at the bequest of US officials, who were keen on using these inspections to gather more intelligence on North Korea's activities, and apply pressure to the regime there. However, the loyalty of IAEA came under question by the international community when it was alleged that it passed all its intelligence information directly to the US. Indeed, it even seemed to some that the IAEA was more concerned with maintaining its sanctity with certain countries like the US through tough posturing, rather than preventing proliferation in the DPRK (Sigal 1998: 40).

The inclusion of the international regime thus became part of the Clinton Administration's battle plan to gain the support of the international community. The administration closely coordinated its military intelligence on North Korea’s nuclear program with the IAEA, and also utilized the legitimacy of the NPT in mustering cooperation from countries and in demanding that North Korea freeze its nuclear production. Indeed, while the inclusion of the NPT and IAEA downgrades criticism from European countries and from South Korea, Japan, China and Russia, Washington remained intent on using the IAEA to rein in the North's nuclear program without having to concede anything in return. Pyongyang was equally determined to exploit its unique status, partly in and partly out of the NPT, to wrest a deal out of Washington.

Following the start of the bilateral talks began in 1994, Clinton abandoned the NPT and the IAEA, a result of North Korea's refusal to allow the international regime to further inspect its nuclear facilities. The exclusion of the international regime was made before the successful

\footnotetext{
${ }^{20}$ See Elich’s (2003) article, “Targeting North Korea” at http://globalresearch.ca/articles/ELI212A.html.
} 
agreement between Washington and Pyongyang, and the Clinton administration based its decision on the view that without the intelligence that can be provided by the IAEA and the NPT, the US would no longer benefit from the international regime. Moreover, the crime-andpunishment approach taken by the IAEA did not suit the administration's policy of engagement.

Another reason why the United States abandoned the IAEA was because of the deteriorating relationship between the IAEA and North Korea, which had started during the first few months of the Clinton Administration (Berry 1995: 8). At the time, several nuclear weapons experts speculated that the DPRK's decision bar IAEA inspectors was mainly predicated on its shock at the sophistication of IAEA inspections, and the belief that access to the additional sites would reveal more conclusively that North Korea was facilitating a nuclear weapons program. This in turn led the Clinton administration to take the threat very seriously, and, understanding the long-term implications of a North Korean withdrawal from the NPT on the international nonproliferation regime, Clinton started to deviate from the international regime framework and instead started to negotiate on its own (Berry 1995:9). Moreover, while the NPT had proved to be moderately successful in mitigating the nuclear regime, it ultimately failed to curtail the North Korean nuclear threat, particularly after North Korea violated the NPT provisions when it removed monitoring equipment the IAEA had installed, expelled inspectors, and announced its intention to resume operations. Thus, the Clinton Administration proceeded with the bilateral talks leaving behind the NPT and the IAEA.

\section{The Effects of Domestic and Systemic Constraints on Clinton Policy}

Some observers surmise that Clinton's policy failed because of its refusal to consider the use of military force in its approach toward North Korea (Feffer 2002:2). This is one reason why Bush, who prefers the use of a more hard-line sticks, i.e., military and sanctions approach, 
deviated from his predecessor's policy. However, some other scholars, such as Sigal (1998, 2000) and Cha (2002), contend that the standoff between North Korea and the United States under Clinton was simply a product of America's unwillingness to cooperate with strangers_-in this case, North Korea. Due to the internally conflicting nature of American politics, Clinton’s policy from 1993-2000 can be characterized as a shift from the inclusion of the IAEA and NPT to its exclusion (Sigal 1998).

As has been consistently argued in the first two chapters of this dissertation, the resolution of the North Korean nuclear program has been met with constraints that come primarily from two sources: domestic and systemic (Amini 2002; Axelrod and Keohane 1985: 226-254; Busch 2002:62; Eberstadt 1996:12; Juster 2000:51-69). Indeed, the shifting strategy policy of the Clinton Administration was largely a product of the domestic constraints it had encountered from the US Congress, American culture and public opinion and bureaucratic politics. Moreover, the inability of the Clinton administration to gain the full support of South Korea, China, Japan and Russia, in terms of policy frameworks and in implementing the strategies of the Clinton administration, had greatly affected the initial policy stance of the US on North Korea. Needless to say, these four countries are instrumental in implementing the policy inclination of Clinton whether it be military or diplomatic and economic rewards or sanctions.

\section{Domestic Constraints ${ }^{21}$}

This study has identified three key domestic constraints that shaped Clinton’s policy on the North Korean nuclear program: (1) the US Congress, (2) American culture and public

\footnotetext{
${ }^{21}$ The following list of sources were largely used in examining the domestic constraints in the Clinton Administration's foreign policy on North Korea: Berry (1995), Bunn (1994), Cha (2002), Cronin (1994), CRS Issue Brief 91141 and CRS Report 95853, Dewar (1994), Lake (1994), Sagan and Waltz (1995), Sanger (1994), Schafer and Crichlow (2002), Sigal (1998), Sokolski (1995), US Senate Committee on Government Affairs (1994, 1995), US Department of State, Bureau of Political Military Affairs (1995), US General Accounting Office (1994, 1995), Wessels (1995), and Zogby (1994).
} 
opinion, and (3) the bureaucratic government. The table below summarizes these constraints.

Table 2. Domestic Constraints (Clinton Administration)

\begin{tabular}{|c|c|}
\hline Variables & Constraints \\
\hline US Congress & $\begin{array}{l}\text { - The process of policy-making was fragmented } \\
\text { - The US Congress limited Clinton's power } \\
\text { - The US Congress limited US funds in dealing with the } \\
\text { - } \quad \text { North Korean nuclear threat } \\
\text { - The US Congress seemed to reject internationalism } \\
\text { strategies, and bilateral and multilateral negotiations }\end{array}$ \\
\hline Public Opinion & 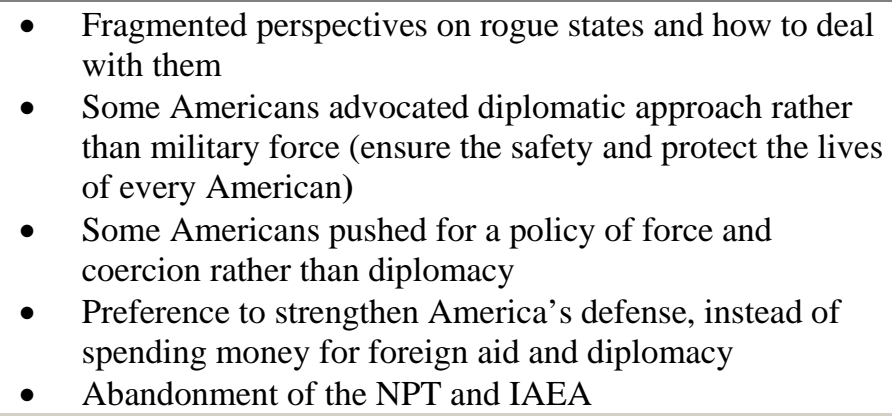 \\
\hline Bureaucracy & $\begin{array}{l}\text { - } \quad \text { Disagreements and the lack of cooperation between the } \\
\text { Departments of State, Energy, Defense, and Commerce; } \\
\text { the ACDA; the intelligence community; and the U.S. } \\
\text { Nuclear Regulatory Commission } \\
\text { - } \quad \text { Reluctance of senior officials to take charge in dealing } \\
\text { with North Korea } \\
\text { - } \quad \text { Defense budget cut } \\
\text { - Instead of redefining ends and means, top officials tried to } \\
\text { avoid tough choices } \\
\text { - The CIA lacked good sources of political intelligence on } \\
\text { North Korea } \\
\text { The nuclear diplomacy employed by the Clinton } \\
\text { administration was but a series of ad hoc improvisations } \\
\text { without any organizing concept }\end{array}$ \\
\hline
\end{tabular}

\section{The US Congress}

The internal formulation of the policy options for the Clinton administration, the debate on the appropriate strategy on North Korea, the appropriation for the said endeavor and the reassessing of the goals and the benefits of the US government in resolving the North Korean nuclear threat took the forefront of the domestic debate. 
The Nuclear Nonproliferation Policy that was adopted by the Clinton Administration had been shaped by previous legislations made by the US Congress (Sokolski 1995; US Senate Committee on Government Affairs 1994, 1995; US Department of State, Bureau of Political Military Affairs 1995; US General Accounting Office 1994, 1995). It then follows that the American Congress, with its power to legislate and direct American foreign policy, can be viewed as one of the foremost drivers of the administration's policy on the DPRK. To illustrate, the US Congress passed The Atomic Energy Act of 1954 (AEA), which evolved into the Nuclear Nonproliferation Act of 1989 (NNPA), provided the framework for the Clinton Administration. The NNPA required the cutoff of US nuclear cooperation with states that violate nuclear cooperation agreements with the US or non-nuclear weapons states that test nuclear weapons.

Moreover, the 1961 Foreign Assistance Act requires the US to cut off economic and military aid to countries that supply or receive unsafeguarded enrichment or reprocessing technology (the Glenn-Symington amendments, Sections 669 and 670), and the 1994 Nuclear Proliferation Prevention Act, requires sanctions against countries that have willfully aided or abetted the acquisition of nuclear weapons or unsafe guarded nuclear weapons materials. Sanctions include the denial of loans or credit from international financial institutions (US General Accounting Office 1994).

Aside from the Congressional legislation that significantly limited the powers of Clinton administration to create a policy approach and strategy to resolve the North Korean problem, another key issue for Congress was the implementation of the agreement, and the extent of the US contribution (US Senate Committee on Government Affairs 1994, 1995, U.S. Department of State, Bureau of Political Military Affairs 1995; US General Accounting Office 1994, 1995). Some lawmakers opposed the use of US funds, but most were apparently not opposed so much 
as to block implementation of the agreement. (See CRS Issue Brief 91141 and CRS Report 95853), and it is without question that the US Congress has always regarded the North Korean nuclear threat as a serious US foreign and security policy concern (Cronin 1994; Dewar 1994: A1; US Senate Committee on Government Affairs, 1994, 1995, U.S. Department of State, Bureau of Political Military Affairs, 1995). Though the debate between the administration and Congress regarding the North Korean policy resulted in the critiquing of the administration's management of American foreign policy (Dewar 1994: A10), questions as to the appropriate policy and implementation strategy began to gain its momentum again when North Korea, in March of 1993, shook the Clinton administration by announcing its intention to withdraw from the NPT (Cronin 1994). The threat that emanated from this announcement played a very significant role in the strategy and approach the administration adopted in its policy formulation towards North Korea. ${ }^{22}$

The Clinton Administration worked with an independent, centralized, partisan and homogenous Congress. This led into constant struggle between the White House and Congress. Clinton Administration never seemed to win its way with Congress. Even during those circumstances when it was able to get Congress' support, Clinton had to exert considerable effort to gain this support.

National Security Advisor Sandy Berger declared in October 1999 that the internationalist consensus that has prevailed in the United States for over five decades is being

\footnotetext{
${ }^{22}$ Although foreign policy and national security come mainly within the turf of the president, the process of policy making was fragmented between many institutions including Congress. This fragmentation arose from the institutional separation of powers, which the American constitution prescribes. A reading of the Constitution will reveal that Congress possesses extensive foreign policy powers. For example, although the president has authority to conduct war and diplomacy, the authority to engage in war and commit the nation to significant foreign undertakings is possessed by Congress. Similarly, while the President is the commander-in-chief and responsible for negotiating and engaging to treaties, there still is the need of the consent by Congress before those treaties are adopted as laws.
} 
challenged by a new isolationism heard and felt particularly in the Congress. ${ }^{23}$ However, many scholars feel that calling Congress isolationist is somewhat excessive. Congress, according to them, does not completely reject internationalism. They however reject Clinton's liberal, globalist brand of internationalism or what conservative thinkers, such as William Kristol and Robert Kagan, called the global buddy system. Like the general public, the Congress holds an opinion that Clinton's enlargement and engagement results in international entanglements, which limits American defense and economic policy options. ${ }^{24}$

Within the executive, there existed fragmentation. The growing complexity of the modern American political environment has witnessed an institutional expansion of the executive branch that has left it with a plethora of various departments, each having to co-exist with one another (Schafer and Crichlow 2000:559-571, 2002:45-68). As such, decision-making becomes complicated by differing perspectives, a problem that has been further exacerbated by personal rivalries and ambitions of key players (Crichlow 2002:45). Thus, even if the conflict between the Congress and the President may be ended, the President would still have to confront an internal bureaucratic struggle within the executive. A further complication was brought about by interest group politics. Various interest groups with different interests lobby for the support of Congress, government departments and agencies. They use lobbyists, media and civic groups to pressure Congress and government agencies, resulting in a multiplicity of issues the administration has to confront, and thus taking away time and resources from foreign policy programs. The difficulty in obtaining Congressional support ultimately pushed the Clinton

\footnotetext{
${ }^{23}$ See the complete text of Berger's speech entitled “American Power: Hegemony, Isolationism or Engagement” at http://www.cfr.org/pub3600/samuel_r_berger/american_power_hegemony_isolationism_or_engagement.php.

${ }^{24}$ Carnegie Endowment for International Peace. 2000. “Allies Do not See a Missile Threat.” http://www.carnegieendowment.org/publications/index.cfm?fa=view\&id=494 (May 29, 2005).
} 
administration to adopt a strategy of going public. The President first approached the public to lobby sufficient support in order to push Congress to support his programs. This made the success and failure of Clinton's programs and prospects dependent on public opinion, though the struggle between fragmented agencies often results in an incoherent and inconsistent policy agenda.

The success of getting domestic and public support is vital to a policy and strategy choice of a president. The complexity of the institutional and bureaucratic system of the US, the separation of powers, and the system of checks and balances requires at least minimal support from the local system, or at least from the Congress. Typically, the foreign policy will have to obtain funding from Congress Appropriations Committee, face public opinion and seek the advice and support of advisers and other key governmental players, and indeed, a lack in support may impede and harm the implementation of his programs. Thus, the inability of the Clinton Administration to get this support may be considered as one of its biggest policy failure. In terms of Clinton's policy to employ a carrots strategy in dealing with the North Korean nuclear crisis, the US Congress made an attempt to influence Clinton’s decision. In November 1994, the Republican Party captured both chambers of the US Congress for the first time in 40 years. The Party established a "Contract with America” campaign platform in the House that was critical of Clinton's handling of foreign policy, and, in doing so, they singled out the DPRK for special concern. When reports of an alleged secret DPRK nuclear weapons site at Kumchang-ni, and Pyongyang's launch of a three-stage Taepo Dong I ballistic missile, in August 1998, emerged, the US Congress passed the Omnibus Appropriations Act 1998 requiring the Clinton administration to appoint a North Korea Policy Coordinator who would be responsible for conducting “a full and complete interagency review of US policy towards North Korea”, and 
"provide policy direction for negotiations with North Korea related to nuclear weapons, ballistic missiles, and other security related issues” (section 582e). In December 1993 Clinton selected retired Vice Adm. Bobby R. Inman to replace Les Aspin as secretary of defense but he refused the offer. Clinton then appointed William J. Perry, deputy secretary of defense under Aspin, for the position.

The resulting report emphasized that it was imperative for the United States to focus on a policy aimed at ending North Korea’s nuclear weapons and long-range missile-related activities. Although some legislators viewed the provision of economic rewards as inherently giving in to North Korean blackmail, the US Congress, through Perry's report, seemed to advocate a carrots strategy. The report recommended a two-path strategy: the complete cessation and the containment of threats. The first path would involve the termination of the DPRK's nuclear weapons and long-range ballistic missile programs, in conjunction with the US initiative to reduce pressures on the DPRK that the latter perceived as threatening. As the DPRK moved to eliminate these programs, South Korea and Japan also promised they would normalize relations with the DPRK, relax sanctions, and take other positive steps toward cooperation. Should the DPRK not accept this first path, the Perry report briefly mentioned that a second path would have the United States, in coordination with its allies, contain the threat (Albright and O’Neill 2000). Up to the end, the Clinton Administration employed carrots approach in addressing the North Korean nuclear threat.

\section{American Public Opinion}

American political, which tends to fluctuate over time, is also one of the domestic constraints, especially as the policies and the strategies of the US are largely affected by public opinion. Political participation thus plays an important role in policy making (Jacobs 1997), and 
the changes in American public opinion often lead to an inconsistency with US foreign policies on other rogue countries such as NK, Iran and Iraq (Cha 2002, Sigal 1998). Moreover, the differing perspectives within the US on rogue states have led to inconsistent policy formulation and implementation.

According to the Arab American Institute, in the first half of 1994, American polls showed that public approval of Clinton's performance in office was a very low 40\%; and while the public's perception of his work on some foreign policy issues was positive, Clinton's overall foreign policy rating was a dismal 34\%. In general, there was little US public support for any military involvement in the developing world. This was true in the case of Haiti, only $38 \%$ percent of Americans felt that vital US interests are at stake, and only 45\% supported the use of force to restore democracy in that country, Bosnia only 31\% felt the US has a vital stake, and Rwanda only $18 \%$ see vital US interests at stake and only $28 \%$ favor the introduction of US ground troops. However, despite these figures, in the case of the North Korean nuclear threat, the American public was in favor of using US troops. ${ }^{25}$ In a poll by the Pew Research Center for the People \& the Press released on April 8, 1999, only 29\% of the American public said that countering the threat of militarism in North Korea should be a top priority. The nuclear issue ranked below concerns about US-China relations and managing trade and economic disputes with Japan.

The Clinton administration remained deeply reluctant to utilize any sort of military force, and the potential retaliatory options of North Korea were too horrifying to even consider. Beyond the obvious threat of nuclear proliferation, the administration also had to consider the

\footnotetext{
${ }^{25}$ In the article, “The Search for Foreign Policy,” James Zogby of Washington Watch discusses the need of the Clinton Administration to show off a success to at least one area of foreign policy. Available online at http://www.aaiusa.org/wwatch_archives/080194.htm
} 
threats of regional instability, terrorism, and international crimes. Moreover, the foreign policy establishment feared that direct confrontation with North Korea would not be easy, since it would most likely fail to gain the support of regional allies such as Japan, China, Russia and South Korea (Zogby 1994).

Considering the complexity and interdependence of countries in the new global setting, nuclear threat does not just affect a country in isolation. Its evils and drawbacks are felt and experienced by other countries. Thus, the central thrust of the Clinton strategy was diplomatic negotiation, in order to create cooperative security measures around the globe. The United States conducted activities such as combined training and exercises, sharing intelligence, systems of cooperative research and development programs, and multilateral peace operations, each intended to support democracy and prevent conflicts before a need for military intervention arises. However, some Americans were tired of promoting international security on moral grounds, such as in the form of aid and diplomacy. Moreover, many considered the external world as corrupt, and deserving of a harsh policy of force and coercion rather than a more peaceful one of diplomacy.

Still, for other Americans, there were numerous threats to US security, such as the possibility of Russia losing control of its nuclear weapons, a rise in nuclear proliferation by rogue states, and a potential conflict with China. Because of these fears, Americans preferred to strengthen its defense by developing new security mechanisms, such as ballistic defense systems, instead of spending their money on foreign aid and diplomacy. Indeed, due to fragmented public opinion, the mutual mistrust between the US and North Korea hindered a diplomatic resolution of the case (Sigal 1998). 
Although the NPT was viewed as successful in establishing a norm against nuclear proliferation (Bunn 1994), it faced significant problems as to why the Clinton administration dismissed the role of the international regime in resolving the North Korean nuclear threats. First, the public regarded it as discriminatory because it divided the world into those who had nuclear weapons and those who had not. Likewise, the labeling of rogue states elicited debates among the public, resulting to fragmented public opinion. The second problem is a perceived failure of reciprocity that encouraged leaders of non-nuclear weapons states to question why they should hold to their end of the agreement when nuclear weapons states had not held to their end. Third, there was a perceived inconsistency of the international norm (Wessels 1995: 50), in that the intention of the DPRK to withdraw from the NPT, and the removal of the IAEA, disproved the importance of these entities to the Clinton administration. With this, as well as the associated public dimension doubting the effectiveness of the role of the NPT and the IAEA, the Clinton administration proceeded on its own in dealing with the North Korean nuclear problem.

\section{Bureaucratic Constraints}

The limitations connected in the policy-making process is further complicated by the implementation constraints of disagreements and the lack of cooperation and coordination between various executive agencies, such as the Departments of State, Energy, Defense, and Commerce; the ACDA; the intelligence community; and the US Nuclear Regulatory Commission (NRC) - which are all involved in the formulation and implementation of nonproliferation policy. Each department had their own role in the implementation of the policies of Clinton, and, as such, the coordination and cooperation of each department was needed in order for the implementation process to be efficient. For instance, the National Security Council is the hub of nonproliferation policy, while the State Department, in consultation with the Energy 
Department and ACDA, negotiates U.S. agreements for nuclear cooperation and represents U.S. nonproliferation interests with other states and international organizations such as the IAEA (US Department of State, 1995), and the Department of Defense is responsible for counterproliferation strategy and policy (US Department of Defense 1996).

The Department of Energy provides expertise in nuclear weapons to support nonproliferation policy and diplomacy, largely through its national laboratories. The Nuclear Regulatory Commission licenses nuclear exports subject to concurrence by the Department of State. The Department of Commerce oversees licensing of dual-use exports, as mandated by Section 309(c) of the Nuclear Non-proliferation Act, which requires controls on "all export items, other than those licensed by the NRC, which could be, if used for purposes other than those for which the export is intended, of significance for nuclear explosive purposes." The CIA has a Nonproliferation Center that coordinates intelligence aspects of nonproliferation policy. The ACDA is responsible for nonproliferation diplomacy such as extending the NPT and negotiating certain agreements (US Senate Committee on Governmental Affairs 1994).

However, the strategy of engagement and enlargement resulted to a restructuring and retrenchment of military capabilities in all agencies of the government. Despite the objections by military officers, defense contractors and other key players, defense budget cuts were implemented, partly due the decline in its value as a percentage of GNP, in dollar terms, and to the shift in the national security perspective. All these budget cuts were developed under Secretary Les Aspin’s Bottom-Up Review (BUR) and the Quadrennial Defense Review (QDR). According to Held and McGrew (1998), these reviews aimed at ensuring that the United States retain its military dominance and its strategic edge in the on-going military technological revolution brought about by the information age (219-242). In addition to the budget cuts, 
military force levels were reduced and re-deployed, and procurement programs cut.

Bureaucratic problems had been evident at the start of the Clinton administration. For some top officials, the policy approach was seen as a sure loser in dealing with North Korea, yet, rather than attempt to redefine ends and means, they avoided tough choices (Sigal 1998). For instance, nuclear diplomacy was the subject of only three Principals' Committee meetings in all of 1993, and many observed what seemed to be a gaping void at the top levels of the bureaucracy (Sigal 1998; Cronin 1994; Berry 1995). Thus, with no one at the top in charge, American diplomatic strategy can be characterized as one of drift, punctuated by spasms of zigzagging. State Department officials, for instance, commented that the lack of regard to the field troops reflected a problem in the implementation strategy of Clinton's policy. Thus, taken together, these problems made the Clinton policy of look like a series of ad hoc improvisations without any organizing concept (Cronin 1994).

This was illustrated by the reluctance of then National Security Adviser Anthony Lake to put together a diplomatic deal that North Korea might find acceptable (Sigal 1998). Indeed, Lake saw himself more as a 'policy broker' than a 'policy entrepreneur' in this case. Secretary of State Warren Christopher, who was acutely sensitive to hawkish pressures, also steered clear of seizing the diplomatic initiative. The conflicts within the bureaucracy during the beginning of the Clinton administration shows that there had been a problem in the coordination among the implementing arm of the North Korean policy. Indeed, the reluctance of senior officials to take charge of effectively dealing with the North Korean crisis, or even to promote deal-making in public, was perhaps the most telling evidence of the politics of the problem. The organizational interests, the main motive in bureaucratic politics explanations, also predisposed most government agencies against a deal with North Korea (Sagan and Waltz 1995: 37; Lake 1994: 
46), though the armed services were a partial but critically important exception.

The above conflict continued on Clinton's second term. The State Department had an interest in maintaining good relations by cooperating with other governments. Yet cooperation with North Korea was not a concern of the State Department, since the US did not have relations with the DPRK (Sigal 1998). Instead, the Bureau of East Asian and Pacific Affairs was mainly concerned about maintaining good relations with ally South Korea. The State Department also had an interest in negotiating with other governments. That interest led it to insist on conducting negotiations on behalf of the United States. It did not necessarily incline the department to favor negotiations, especially when officials believed that talks would be fruitless, or worse, when they felt the other side would take advantage of talks to pursue its nuclear ambitions (Lake 1994: 46).

To nonproliferation specialists in the State Department and especially in ACDA, preventing proliferation was seen as synonymous with preserving and protecting the prerogatives of the IAEA. Nonproliferation specialists in the Pentagon, however, defined their interests differently. They were preoccupied with preventing NK from producing any more plutonium or diverting what it had to weapons production, and their difference in outlook led them to take opposing stands at interagency meetings (Sanger 1994: A9; Sagan and Waltz 1995: 37). The CIA lacked good sources of political intelligence on North Korea. The CIA did not have agents in Pyongyang with access to top political authorities or affiliates of its nuclear program. Nor did it have extensive intelligence liaison with South Korea, which could have biased its assessments (Sagan and Waltz 1995: 37). Nor did it place much confidence in other human intelligence sources. Less explicably, analysts were also discouraged from talking to North Korean diplomats and visitors, or to academics who studied North Korea. All of this made the CIA especially dependent on national technical means. 
The diagram below provides a simplification of the domestic constraints that effected Clinton’s policy towards North Korea.

Figure 2. Impact of Domestic Constraints on Clinton’s Policy

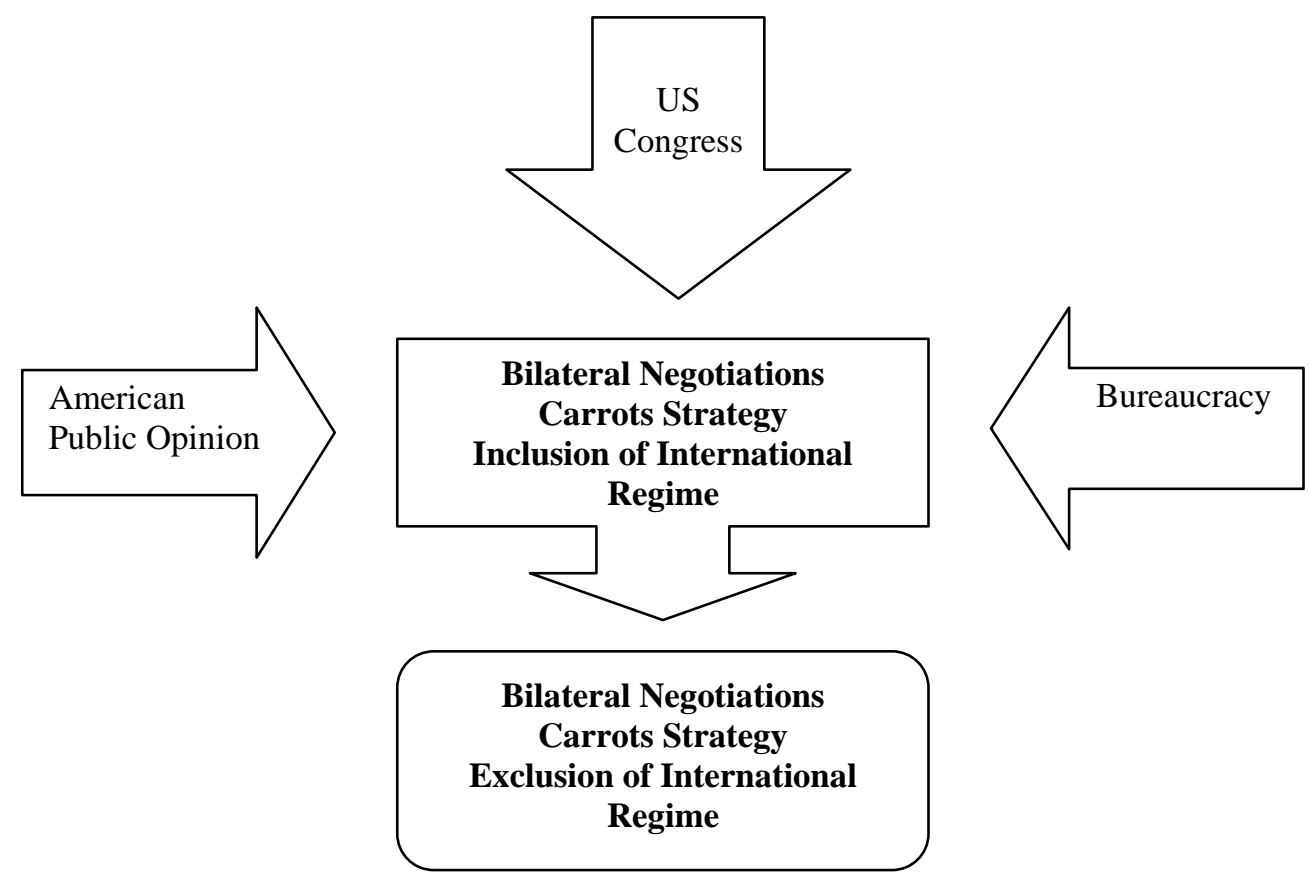

The figure indicates that, of the original strategies employed by the administration, only the policy of the inclusion of the international regime was changed. Note that this is not to say that other domestic constraints that have been taken under consideration did not impact Clinton's policies; it only shows that the Clinton administration was generally unmoved by these factors despite their crucial roles. It can be surmised that the Clinton administration did not resolve the North Korean nuclear threat because it resisted the influential domestic factors.

\section{Systemic Constraints on U.S. Foreign Policy}

Systemic constraints in the Clinton administration consisted largely of one factor: the lack of cooperation and consistency between the US and its partners such as South Korea, China, Japan and Russia. The differences have been in the policy orientation of each of the countries, 
their program for action, and the inability of the countries to cooperate. Table 2 summarizes the systemic constraints faced by the Clinton administration. ${ }^{26}$

Table 3. Systemic Constraints (Clinton Administration)

\begin{tabular}{|c|c|}
\hline Variables & Constraints \\
\hline $\begin{array}{l}\text { Inconsistencies between US and } \\
\text { other foreign policies on NK }\end{array}$ & $\begin{array}{l}\text { - The US failed to get the full confidence of South Korea, } \\
\text { - } \quad \text { The South Korean government called on the Clinton } \\
\text { administration to avoid unilateral concessions to North } \\
\text { Korea } \\
\text { - In the face of a hardening US attitude, South Korea } \\
\text { appeared to seek a softer line } \\
\text { - Although the Japanese government fully shared American } \\
\text { concerns, it was reluctant to go along with the US threats } \\
\text { to impose economic sanctions on North Korea } \\
\text { Japan strongly preferred an approach emphasizing } \\
\text { diplomacy } \\
\text { China opposed the introduction of harsh measures against } \\
\text { the DPRK in order to preserve its self-interest on North } \\
\text { Korea } \\
\text { In dealing with North Korea's nuclear intransigence, } \\
\text { Russia preferred to prevent any unilateral American move }\end{array}$ \\
\hline $\begin{array}{l}\text { Differing US and NK } \\
\text { philosophies regarding nuclear } \\
\text { programs }\end{array}$ & $\begin{array}{l}\text { - US viewed North Korean nuclear program as a bargaining } \\
\text { chip } \\
\text { - North Korea viewed its nuclear program as a means to } \\
\text { defend itself from foreign adversaries }\end{array}$ \\
\hline
\end{tabular}

While each of these actors broadly shared United States concerns and goals, each preferred different variants of a low-key approach, for various reasons. Indeed, policy options of the Clinton Administration were limited because economic, political and military approaches were severely hindered by the failure of cooperation between each of the actors.

\section{Japan, South Korea, China, and Russia}

A major difficulty facing the Clinton Administration had been its inability to build sufficient domestic and international confidence necessary for implementing their initiatives. The

\footnotetext{
${ }^{26}$ The following sources were used to construct the table on the systemic constraints of the Clinton Administration: Cronin (1994), Fisher (1994), Jones (1993), Khalilzad, Davis and Shulsky (1993), Kim (1998), Kucia (2003), Lukin (2003), Oh and Hassid (2000), Sanger (1993, 1994), Telenko (2003), and Wheeler (2003).
} 
refusal to support American efforts to isolate North Korea had been very embarrassing to the Clinton administration, and raised questions about its ability to play a leadership role in international affairs. Failures such as this had led some to suggest that Clinton has turned former President Theodore Roosevelt's maxim of speaking softly but carrying a big stick around to talking tough and carrying no stick at all (Zogby 1994). The political stakes attributed to the failure of diplomacy in reining-in Pyongyang's nuclear program could raise or intensify several sensitive defense issues between the US and other countries, especially Japan and South Korea, and, moreover, could potentially jeopardize US global nonproliferation objectives. In a report to the US Congress in 1994, it was found that one of the factors contributing to the outcome of US policy on North Korea was the inability of the administration to forge cooperation between the United States and other countries (Cronin, 1994).

The Clinton Administration's policy of engagement and containment started to look vulnerable, as evidenced by the reluctance of the Japanese government to cooperate with the US (Kim 1998: 116-135). Instead, the Japanese Liberal Democratic Party (LDP) started to contemplate whether to renew its support of the NPT after it expired in 1995 (Jones 1993: 4). This was aggravated by the pronouncements of then Foreign Minister Kabun Muto that Japan was also entertaining thoughts of building its own nuclear program if necessary (Washington Post July 29, 1993: A18; Japan Times Weekly International January 31-February 6, 1994: 5). This pronouncement, together with Japan's indecision, made it quite clear that the United States had yet to gain the full confidence and cooperation of one of its key allies, in its quest to resolve the North Korean nuclear threat (Kim 1998: 116-135). A diplomatic failure could also potentially affect negotiations on other issues, such as the future powers of the IAEA, and the means of ensuring compliance when individual signatory nations violate their obligations under the treaty. 
While the South Korean government had preferred a policy of diplomatic engagement rather than the use of force, this position contained several inconsistencies. The South Korean government, under President Kim Young Sam, had several important but conflicting concerns about the US and the international response to the North Korean nuclear program (Cronin 1994). For instance, President Kim warned publicly in June 1993—a period of active US consultation regarding possible initiatives on North Korea— that the Clinton Administration should avoid unilateral concessions to the North. Ironically, in the face of a hardening US attitude, South Korea appeared to seek a softer line (Sanger 1994: A8). In early and mid-February of 1994, in the midst of a dispute between Pyongyang and the IAEA over the scope of a one-time inspection of its declared nuclear facilities, the Kim government sought to quell calls for economic sanctions. After the DPRK agreed, on February 15, to the IAEA's terms for a one-time inspection, Seoul indicated its reluctance about the deployment of US Patriot missiles. President Kim and his cabinet also associated themselves with a softer line during high-level visits to Japan and China in late March, emphasizing the need for continued diplomacy rather than sanctions or other pressures.

In mid-April the same year, in an apparent effort to induce North Korea to allow the IAEA to complete an inspection of its reprocessing facility, the Kim government reversed course over the contentious issue of whether envoys needed to be exchanged between the North and South as a precondition for further high-level talks between Washington and Pyongyang (Smith 1994a: A13; Smith 1994b: A22). The shift in South Korean policy toward the DPRK was frustrating to American negotiators and officials, though while there were many instances of these policy swings, in general, when the Clinton administration had taken a tougher position, the South Koreans simply urged caution and vice versa. 
In the United States-Japan case, the Japanese government fully shared American concerns about a nuclear-armed North Korea, but was reluctant to go along with American threats of imposing economic sanctions on the North (Kim 1998: 116-135). Instead, while Japan sought to maintain solidarity with the United States on the issue, it strongly preferred an approach emphasizing patient diplomacy. Japan's cautious stance, and similar reluctance about confrontation on the part of South Korea, had been major factors in the Clinton administration policy shifts on the issue of seeking UN sanctions (Sanger 1993: 6). Many analysts judged that Japan would have little choice but to support economic sanctions or other measures regardless of the politics of the issue, and it was reported that Japan and the United States already discussed and came to agreement on the role that Japan would play, including, by implication, a cutoff of remittances from ethnic Koreans (FBIS, 1994: 7-8). Nonetheless, a move to impose sanctions under the guise of UN Security Council authority probably would have provoked a political crisis, and any effort to impose sanctions outside the UN framework, or involve Japanese SelfDefense Forces could have created a more serious crisis.

Some observers believed that, while the Clinton Administration lacked good short-term options to rein in North Korea's nuclear program, the long-term outlook appeared to be more optimistic, because of the regime's impending implosion (Sanger, 1993: 6). Indeed, according to some press analysis, the option of waiting out North Korea may have been the real administration strategy (Cronin, 1994). The expectation of collapse was also said to be one reason for South Korean and Japanese "timidity” (Khalilzad, Davis and Shulsky 1993: 3; Sanger 1993: 6). This option of waiting out conformed most closely to the preferred course of China and to a number of Japanese political leaders. 
China's support was arguably been even more important than Japan's, but it had contradictions with the Clinton Administration's policy. Although China did not want nuclear weapons on the Korean peninsula, it also had opposed the introduction of harsh measures against the DPRK. This policy was partly explained by the argument that China had historically opposed actions which could be interpreted as interference in the internal affairs of other states. From a strategic point of view, Chinese officials understood that the DPRK risked military confrontation on the peninsula, and could prompt South Korea, Japan and possibly even Taiwan to develop nuclear weapons_-greatly complicating China's security and diverting attention and resources away from Beijing's top priority - economic modernization. Beijing appeared to be in a dilemma, however, as to what to do about it. China's reluctance to apply sharp economic and political pressure on North Korea was largely because, apart from any remaining sense of socialist solidarity, Beijing would be highly disturbed by the prospect of a military conflict in a neighboring area. Beijing also felt a need to keep communication lines with North Korea open, which they viewed as being critical to maintaining Chinese influence on the peninsula and helping to preserve peace there. Beijing therefore wanted to avoid sanctions that would require cutting off Chinese supplies of food, oil and other goods. Beijing also wanted to preserve its special channels of communication with the North Korean Army and Party-elements of power likely to be pivotal in determining the leadership succession in Pyongyang following the death of Kim Il Sung.

Russia, on the other hand, believed that North Korea was not capable of producing nuclear weapons, and was suspicious that the state was using its nuclear program as a bargaining chip (Lukin, 2003: 1). By joining its voice with the US condemnation of North Korea's nuclear weapons program, Russia made a mid-course correction of its policy toward the Korean 
peninsula that was designed to preserve its influence. Russian scholar Alexander Lukin (2003: 1) posited four reasons why Moscow was in a good position to help bring about a peaceful settlement with North Korea. First, he argues that Russia's permanent seat on the UN Security Council put it in a position to influence international action on North Korean WMD. Second, Russia had provided the DPRK with its most effective conventional weapons. Third, Russia's proximity to the peninsula like China's legitimized its concern over a US war in the region, and Moscow or Beijing could block a war if they thought it was too threatening to their own security. Finally, all sides believed that a gradual, peaceful unification of the peninsula was essential to the prospects of an economically viable Korean state. Based on their common interests, Lukin (2003: 1) argued that North Korea should accept a multilateral framework for negotiations that included Russia, and that in doing so would begin a successful push toward peace and nonproliferation on the Korean peninsula.

In dealing with North Korea's nuclear intransigence, Russia would prefer to prevent any unilateral American move and so found itself on the side of South Korea, Japan and China. Korea was an important field in Russia's international strategy, both before and during the Soviet period. In the first half of the 1990s, a relative loss of interest towards the Far East and in Asia in general—caused by the one-sided pro-Western orientation of the Kremlin—gradually gave way to a more balanced approach, a change that naturally influenced Moscow's Korea policy, and its resulting pragmatic policy towards both Koreas can be attributed to several general factors (Kucia 2003). First, few in the Kremlin doubted that the North Korean regime was historically doomed. Though they understood that it might take five, ten or fifteen years, they believed it would disappear sooner or later from the world political map, and a new and united Korea would emerge as Russia's neighbor. South Korea, a country much more populous and developed than 
the DPRK, would surely be its core.

North Korea's insistence on dealing only with Washington on the issue seemed unreasonable to Moscow, since they believed that any American security guarantees made to Pyongyang could hardly be of great value. It was widely recognized that China, and to a lesser extent Russia, were the countries which could press the DPRK to fulfill any agreement reached with the United States. But China and Russia were also the only countries that could give Pyongyang formidable security guarantees against the United States, as through the shared border with North Korea, Russia and China could effectively prevent a US military action in North Korea if they thought it was unreasonable and too dangerous.

To summarize, South Korea, Japan, China, and Russia were all opposed for the reasons listed above to Clinton's bilateral approach, and instead argued that it was in the best interest of all if the administration adopted multilateral negotiations. Moreover, these powers did not support American plans for imposing economic sanctions on the DPRK, but rather argued that economic rewards would provide a more effective strategy in resolving the North Korean nuclear threat, and advocated diplomacy to preserve their own interests in the region. Finally, it can be said that the Clinton Administration might have dismissed the help of the NPT and the IAEA because of the pressures from each of these countries.

\section{The Kim Regime}

The DPRK is the most secretive, xenophobic and militaristic country in the world, and because its actions are often shrouded in mystery, much ambiguity surrounds North Korea’s intentions and capabilities, including important details concerning its nuclear weapons program (International Crisis Group 2003). Indeed, this may be the reason why most outsiders associate uncertainty with the DPRK. The DPRK's official ideology is “Juche,” which translates to a 
“combination of national self-reliance and Korean nationalism” (Oh and Hassig 2000: 15). To the few visitors allowed into the country, the DPRK seems like an Orwellian society that time forgot (International Crisis Group 2003).

The role of Kim Il Sung in the North Korean stance of US policy-in addition to the significant loss of economic, military and international political support from China and Russia, as well as the normalization of diplomatic relations between Seoul and China, and the rapidly growing trade and investment ties between China and South Korea-is the most important factor in the stance of NK on US policies. These developments appear to have led to two broad responses by the secretive, Stalinist regime of President Kim Il Sung, who had headed the state since 1948. The first was been a cautious effort to imitate some aspects of China's economic reforms, in order to shore up declining living standards, check any tendencies towards popular or elite discontent, and increase hard currency earnings. The second response-the main focus of the current confrontation — appears to be the continued and accelerated development of North Korea's nuclear programs and its development of ballistic missile capabilities.

Wendy Sherman, a former State Department counselor and adviser to Clinton and thensecretary of state Madeleine Albright, told the US Institute for Peace that the Clinton administration concluded that the Kim regime was not about to collapse. According to the US House of Representatives Task Force on Terrorism and Unconventional Warfare (TFTUW), leadership in North Korea would consistently refuse to give up nuclear weapons, no matter how many agreements it might enter into with the US. One defector, Kang Myong-To, stated that North Korea's nuclear development was not intended as a bargaining chip, but a means to 
preserve Kim Jong-Il's regime, ${ }^{27}$ Yossef Bodansky, the TFTUW director, has commented that "Nuclear weapons are the ultimate insurance policy of the ruling elite" in the DPRK. ${ }^{28}$ According to General Leon J. LaPorte, Commander of American Forces in Korea, Kim Jong-il is firmly in control of power, and that, "He [Kim Jong-Il] is the ultimate decision-maker who controls the state security apparatus and occupies all key party, military and government leadership positions...Kim’s overriding goal is regime survival” (International Crisis Group 2003: 2).

For some time the stated long term strategy of the Clinton Administration was to negotiate a comprehensive settlement of Korean peninsula issues, in which North Korea's acceptance of inspections would be matched by new political, economic and security overtures on the part of the US. The agreement between the two countries dictated that the United States would not use force in resolving the nuclear situation, and that it would not meddle with the internal situation in North Korea (Cronin 1994). North Korea, in turn, would allow the IAEA to conduct a one-time inspection of Pyongyang's seven declared sites to replace film and batteries in cameras, and to reestablish the continuity of the inspections regime. The primary reason for the breakdown of the negotiation can be traced to the differing interpretations of the two countries on the agreement (Fisher 1994: 4-5), where, for instance, North Korea alleged that the IAEA went beyond what has been agreed with the United States (Sanger 1994: A8).

Indeed, the success of Clinton's policy of engagement towards North Korea was largely undermined by North Korea's concern for its own survival, in that it feared the possibility of a German-style absorption by South Korea, as well as the possibility of US aggression. Thus,

\footnotetext{
${ }^{27}$ Telenko, Trent. 2003. "North Korea: Clinton Knew...And 'Kicked the Can Anyway.,” http://www.windsofchange.net/archives/north_korea_clinton_knewand_kicked_the_can_anyway-print.php (May 29, 2005).

${ }^{28}$ Wheeler, Scott L. 2003. “Clinton Ignored Kim Jong-il's Nukes.” http://www.insightmag.com/main.cfm?include=detail\&storyid=342934 (July 3, 2004).
} 
despite economic constraints, it chose to develop and have the appearance of developing nuclear weapons. While North Korea recognized the need for reform in order to survive, it feared that opening up its borders would cause internal instability and weaken its own political position. Being unable to compete through only conventional weapons, North Korea focused on developing weapons of mass destruction to gain upper hand. As a result, the country was able to threaten South Korea, China and other neighbor states, and, moreover, force the United States to provide economic concessions.

With regards to the approach employed by the Clinton Administration, the DPRK had favored bilateral negotiations. Through a succession of bilateral talks, the United States and North Korea entered into the Agreed Framework, which provided economic rewards to North Korea if it were to freeze all its nuclear activities. As the negotiations were going positively between the United States and North Korea, the administration continued to engage in bilateral talks and employ diplomacy through economic support. In relation to the international regime, when the Kim regime was beginning to lose confidence and trust with the NPT and the IAEA, and eventually withdrew from the NPT, the Clinton Administration used this situation to exclude the international regime from its policy. The diagram below is an oversimplification of systemic constraints faced by the Clinton Administration in resolving the North Korean nuclear problem, and their impact on the implementation of Clinton's policy.

Figure 3. Impact of Systemic Constraints on Clinton's Policy
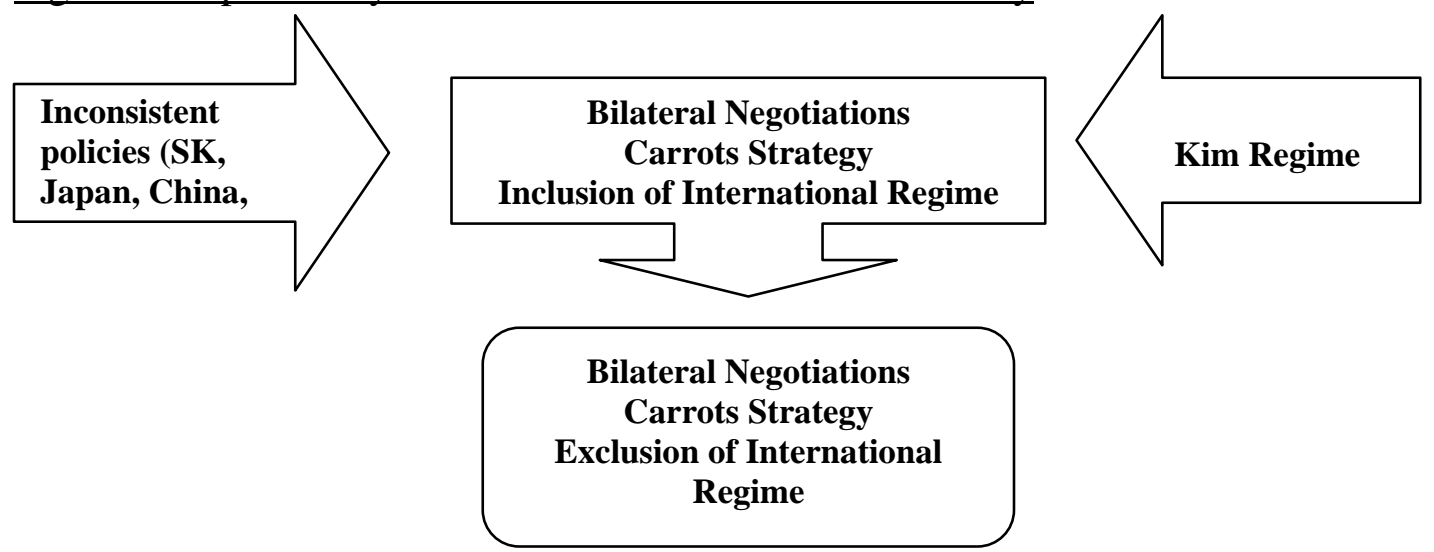
As can be gleaned from Figure 2 (Impact of Domestic Constraints on Clinton’s Policy), Figure 3 shows that only the Clinton Administration's policy on the inclusion of the international regime was changed. Note that this does not mean that these systemic had no impact on Clinton's policies. The Clinton Administration was firm on its stand, despite the impacts of these variables.

\section{Synthesis}

The Clinton Administration entered office in January 1993 almost completely unprepared for dealing with the North Korean nuclear crisis. Clinton had been elected on a platform emphasizing the domestic economy, but he inherited a diplomatic strategy that would determine the success of his administration's foreign policies. In an attempt to resolve the crisis, the Clinton Administration preferred a tough bilateral inspection regime, but had failed. A second, alternative strategy, the use of diplomacy and economic rewards instead of military force and economic sanctions had generated debates, as the approach was perceived by many as appeasing the Kim regime. The third choice, the IAEA, had succeeded in uncovering evidence of DPRK cheating, but was unable to force the state to come clean about its nuclear activities, thus the abandonment by the Clinton Administration of the international regime. Table 4 below outlines the shift of Clinton's policy on North Korea.

In its foreign policy towards North Korea, the United States failed to consider the regime characteristics of North Korea, as well as the power relations in the region. Clinton's policies often seemed to take the form of experimentation, shifting only when they failed to attain support from regional powers. As both the extent to which Kim Jong Il has consolidated power, and military check on his authority remained in question, the Clinton Administration was only able to guess about the ability of Kim Jong II to influence the North Korean reaction to US policy, 
whether diplomatic or military. It also failed to give careful consideration to the primary objective and motivation of North Korea in developing nuclear weapons, which is regime security.

Table 4. Clinton's North Korean Nuclear Policy

\begin{tabular}{|c|c|c|}
\hline Variables & Beginning & End \\
\hline Type of Negotiation & Bilateral & Bilateral \\
\hline $\begin{array}{c}\text { Sanctions/Rewards } \\
\text { (Statecrafts) }\end{array}$ & Carrot (Economic, Diplomatic) & Carrot (Economic, Diplomatic) \\
\hline Role of International Regime & Major & Minor \\
\hline
\end{tabular}

North Korea’s leverage in negotiation did not come from its negotiation tactics or from the danger posed by its economic programs and economic situations, but rather, it mainly derives from its geopolitical conditions. It successfully used uncertainty, ambiguity and unpredictability and traditional blackmail as its key strategy. On the one hand, the United States should have seen that the current economic condition of North Korea would deter it from going to war, and risk faster self-destruction. The United States, instead of threatening military and economic sanctions, should have initiated a cooperative relationship from the very start, and should have considered the North Korean desire for political and regime stability. North Korea issued similar threats of war and used brinkmanship tactics to get what it wanted, the Agreed Framework of 1994. The United States needs to be more sensitive to the security concerns and economic motivations of North Korea. The administration should have understood that North Korea would accept change only if it could guarantee security for the regime, and it should inquire as to the reason for North Korea's apprehension towards a United States-led attack. Also, the Clinton administration should have understood Pyongyang's doubts as to the stability of the regime if it decided to initiate reform and open up the country. 
In relation to the internal characteristics of the target state, the United States should have determined the conditions of which there are two that would make target states seek engagement to the United States. The first condition arises in a state of economic crisis that threatens a ruling regime. In the case of Pyongyang, Kim II Sung's decision to initiate a limited opening to the West was based on North Korea's worsening economic problem. The gravity of the situation in North Korea, the economic contractions and the food and energy shortages, made it realized its need for normalized diplomatic relations with other countries, especially the United States, for its regime's survival. These economic hardships allowed other countries to engage North Korea in diplomatic relations with the hope that North Korea would eventually open up and initiate democratic reforms. Aside from economic crisis, national security concerns, which provide the second condition, could also induce a diplomatically isolated state to seek engagement. To ensure security, countries are often willing to work with each other to deter possible threats of aggression. The narrow containment policy towards Iraq, for example, was not aimed solely to the overthrow of Saddam Hussein or to the collapse of his regime. As for the case of North Korea, the United States has been able to create a small coalition of countries with the shared policy objective of ending the North Korean threat.

It should be observed that both conditions, security and economic constraints, are worsened by the isolation of North Korea. However, the United States learned that it cannot always push isolation by the use of economic and military sanctions and closing up on the country. In the case of North Korea, instead of isolating the country and further exacerbating its internal economic and security conditions, the Clinton Administration found the utility of taking advantage of Pyongyang's current problems through engagement. However, the Clinton Administration's failure to achieve a consensus among the other major powers which is relevant 
to create a successful multilateral relation only weakened the probability of success for its policies. The credibility and effectiveness of international economic rewards and sanctions depend on the willingness of states to effectively impose them, though each country's choice of imposing economic sanctions depends on the country alone. While the United States can make attempts to pressure them, it obviously cannot use force because it will defeat the purpose of diplomatic cooperation. Indeed, a key problem lies with the fact that Asian governments tend to adopt a different policy choice from the Unite States. When Clinton adopted an aggressive approach, other countries, especially China, disapproved for fear of initiating a major conflict. On the other hand, when the administration decided to pursue a diplomatic stance, it received criticism from South Korea for lacking the firmness necessary to curtail North Korean efforts for nuclear weapons development.

The signing of the bilateral agreement, the Agreed Framework, between North Korea and the United States induced cooperation among major powers. However, in doing so, it left out China and Russia, two of the central regional actors. Under the agreement, the leadership for the Korean Energy Development Organization (KEDO), the organization responsible for funding the oil supplies and construction of reactors for North Korea, is American, while Japan, South Korea and other countries agreed to provide most of the funds. China and Russia were only invited as ordinary members because they did not contribute funds, an action putting them in an embarrassing situation, thus they declined the invitation. It should be noted that after the event, China expressed willingness to support the Agreed Framework, though Russia, on the other hand, expressed disappointment for the exclusion. The other major criticism of the Clinton Administration was over its failure to gain support from its own domestic institutions. As noted above, the administration was in a constant struggle with Congress over the issue. It received 
consistent criticism from the public and local institutions, whose interests were different from Clinton’s policy priorities. Moreover, these domestic institutions and the public held Clinton responsible for the weakening of the US defense by cutting defense spending. For them, priority should be given to the strengthening of US defense instead of giving away foreign aid and engaging to diplomatic relations, and thus leaving the Unite States vulnerable to external aggression. Finally, Clinton’s choice of bilateral diplomacy towards North Korea was widely criticized as a show of weakness by the administration. 


\section{CHAPTER IV: SYSTEMIC AND DOMESTIC CONSTRAINTS IN SECOND BUSH AdMINISTRATION POLICY ON NORTH KOREA}

From the beginning of the Bush administration, it has shown its deviation from the Clinton administration’s North Korean policy: Bush adopted a conservative internationalist approach, as opposed to the liberal internationalist approach of Clinton. Bush demanded that North Korea destroy its nuclear weapons as a precondition to resuming talks with Pyongyang. Bush used a multilateral approach without ruling out economic and military sanctions and employed a hard line approach to North Korea. ${ }^{29}$ The main components of Bush’s policy include: (1) terminating the Agreed Framework; (2) no negotiations with North Korea until it dismantles its nuclear program; (3) assembling an international coalition to apply economic pressure on North Korea; (4) planning for future economic sanctions and military interdiction against North Korea; and (5) warning North Korea not to reprocess nuclear weapons-grade plutonium, and asserting that "all options are open," including military options (Niksch 2003: ii). As the previous chapter examined how domestic and systemic constraints affected Clinton's North Korean policy, this chapter shall illustrate the domestic and systemic constraints that the Bush Administration has struggled against. As with the Clinton policy, it can be argued that because of these limitations and constraints, a similar policy approach will be adopted by the Bush Administration. The illustration below will be used as a framework for analysis on this chapter.

\footnotetext{
${ }^{29}$ The following sources were used in this study to construct the Bush Foreign Policy on the North Korean nuclear crisis: Carlson (2003), Cha (2002), Choi (2003), Diehl (2002), Fein (2003), George W. Bush Administration Policy Toward North Korea (2004), Heginbotham (2003), Kerr (2003), Koh (2003), Koppel and Labbot (2001), LaMontagne (2002), Lee and Feffer (2004), Niksch (2003), Pollack (2001), Sherman (2002), Perry (2001), Conachy (2001), Gross (2001, 2001).
} 
Figure 4. Framework for Analysis (Bush Administration)

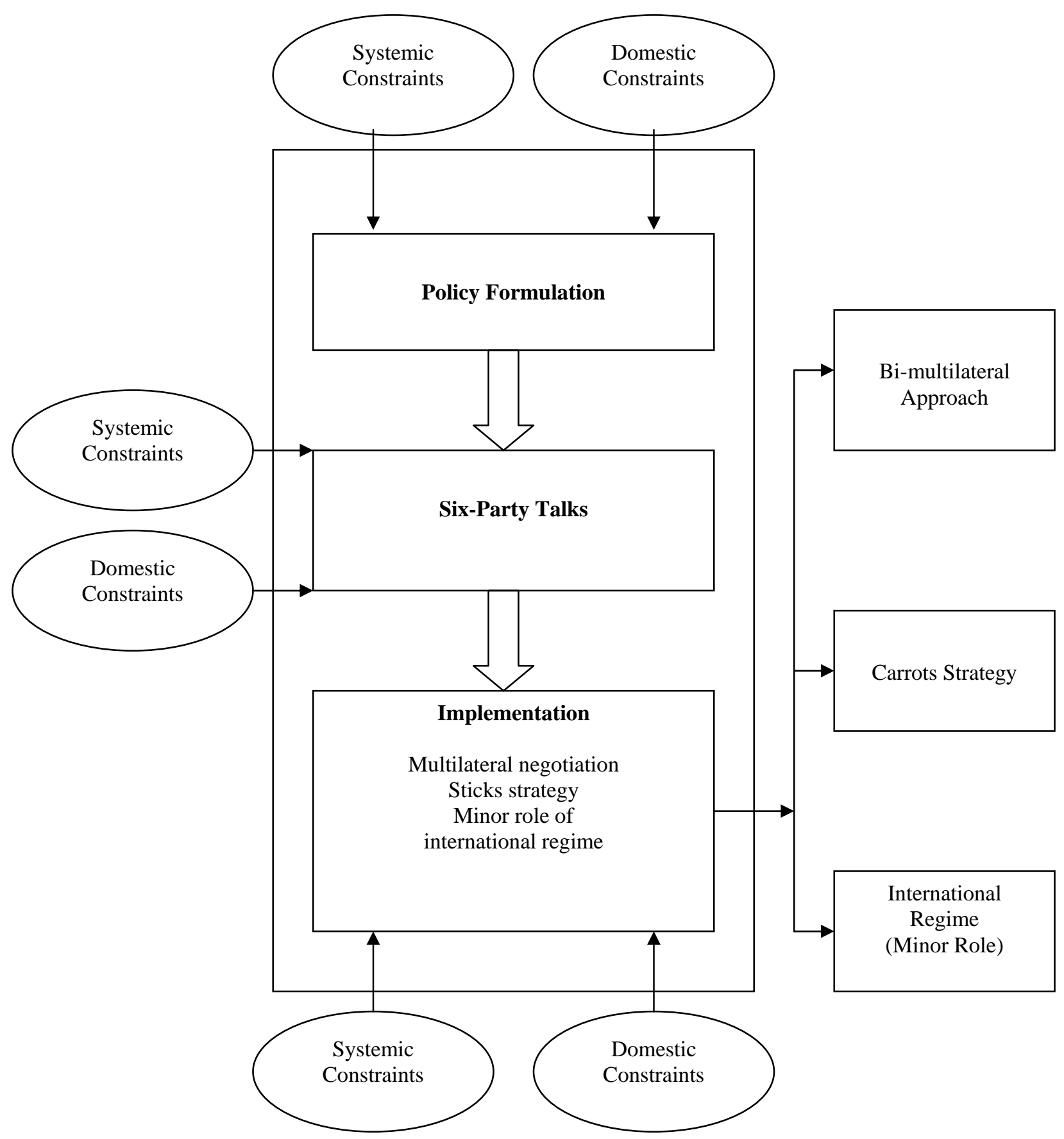

The first section of this chapter illustrates the policy and strategy of the Bush

administration at the start of its term, and the rationale of the policies and the strategy that was used by the Bush administration will be evaluated. The second section presents the systemic and 
domestic constraints that challenged the initial policy and strategy formation of the Bush administration. Specifically, domestic constraints such as the opposition in the Congress, the lack of military power and the attitude of the United States on North Korea will be evaluated.

Moreover, the systemic constraints, which include the problem of the United States to form a solid cooperation among its allies such as South Korea and Japan, and China and Russia, are assessed. Finally the role and attitudes of the Kim Jong-Il regime will be analyzed.

Figure 4 shows that the Bush Administration was besieged by both domestic and systemic constraints from the moment it started to formulate its policies and implementation strategies. Clearly, the rationale behind the previous administration's foreign policies was rejected by the current administration. Moreover, even from the decision to choose its policy instruments such as multilateralism, sticks, use of military, the administration was hounded by domestic and systemic constraints.

\section{Bush Administration's Initial Policy on North Korea ${ }^{30}$}

The Bush administration set up a new foundation for its relationship with North Korea. When George W. Bush took office in January 2001, the hard line position toward North Korea has been expected (Il-whan 2002: 3-20) given the administration’s highly skeptical view of prior US policy initiatives toward Pyongyang (Pollack 2001: 6; Sherman 2002). ${ }^{31}$ Bush issued a statement on June 6, 2001, outlining the United States’ new policy objectives over North Korea's

\footnotetext{
${ }^{30}$ The researcher found an abundance of literature about the Bush Administration's initial foreign policy on North Korea. Some of the important articles and books include: Adkins (2003), Bunn (2003), Carlson (2003), Conachy (2001, 2004), Diehl (2002), East Asia Review (Autumn 2002), Fein (2003), Heginbotham (2003), Kerr (2003), Koppel and King (2002), Koppel and Labbot (2001), Lea (2001), Lee (2003), Faiola and Cody (2004), Hoagland (2003), Hwang (2002), Kucia (2003), Kurtz (2003), LaMontagne (2002, Lew (2004), Niksch (2001), Perry (2001), Pickett (2004), Pickett and Purnell (2004), Pollack (2001), Scheinman (2000), Sherman (2002), and Sokolski (2002).

${ }^{31}$ It should be noted that at the time, some Washington observers believed that the new administration was simply trying to create some distance from Clinton's legacy of successes in US-NK relations before launching its own policy of engagement (Lee 2003).
} 
nuclear and missile program and its conventional forces. Bush stated that if North Korea took positive actions in response to his policy, the United States "will expand our efforts to help the North Korean people, ease sanctions and take other political steps" (Niksch 2001: 1). The Bush Administration's policy sought to curtail even the conventional elements of North Korean military power, and to secure absolute US hegemony in Northeast Asia.

In March 2001, the Bush administration publicly cast doubt on the Sunshine Policy, insisting on the necessity of a policy review before further Unite States-North Korea negotiations could take place. Furthermore, Bush and Secretary of State Colin Powell publicly referred to the Pyongyang regime as “untrustworthy” and branded Kim Jong II a “dictator,” thus angering the North Korean regime (Lea 2001). Consequently, the US-NK relations that had progressed rapidly toward the end of the Clinton administration ended in a standoff (Adkins 2003; Bunn 2003; Conachy 2004; Il-whan 2002; Kerr 2003; Faiola and Cody 2004: A14; Hoagland 2003: B7; Hwang 2002; Kurtz 2003; Lew 2004; Pickett 2004; Scheinman 2000).

While still in the government, advocates of the Agreed Framework sensed early on that Bush did not show any positive incentives to cooperate or acquiesce (Sokolski 2002). The Bush Administration began to stress American global leadership and national interests, and its foreign policy was largely molded on the Republicans' traditional diplomatic and security policy ideology of American internationalism, which includes the possible use of force. Indeed, this hard line approach was expressed on January 26, 2001, when Powell met with Japanese Secretary of State Yohei Kono for talks, and commented that the US policy toward North Korea would be based on "raw reality” (Il-whan 2002: 3-20). The Bush administration, after some preliminary steps which included an internal policy review, visit to Seoul by Undersecretary Richard L. Armitage, and coordination through the Trilateral Coordination and Oversight Group 
(TCOG) among South Korea, the US, and Japan, released its policy outline toward North Korea in a presidential statement (Il-whan 2002) on June 6, 2001. This proposed three agenda priorities, including: (1) stepped-up efforts by NK to implement the Geneva Agreed Framework, (2) verifiable deterrence and an export ban on missiles, and (3) the gradual elimination of conventional weapons (Statement of the President, June 6, 2001). In addition, the statement announced that if the DPRK reacted positively, the US would provide economic assistance, and propose a comprehensive package to improve bilateral relations (Kerr 2003). On June 13, 2001, working-level talks took place in New York between Jack Pritchard, the United States special envoy for Korea Peace Talks, and Ri Hyong-chul, the North Korean ambassador to the UN. In this talk, Ri strongly criticized the hostile US policy, and demanded compensation for lost electricity, 50\% material compensation for losses suffered due to halted missile exports, and the withdrawal of US forces stationed in South Korea (Lea 2001). The North Korean ministry announced that the three-point agenda put forth by the Bush Administration was unilateral and hostile in nature, and argued that it was nothing but a plot to disarm NK (Lea 2001).

The Bush Administration's decision to adopt a policy of strict reciprocity has had a negative impact on prospects for Unite States -North Korea talks. Furthermore, the strong rhetoric and hard-line foreign policy approach of the Bush Administration not only limited North and South Koreas’ ability to take a leading role in resolving Korean peninsula issues, but also damaged the improved relations between the Unite States and North Korea that had begun to emerge at the end of the Clinton Administration (Il-whan 2002).

Since the release of the US policy review on North Korea in June 2001, the Bush Administration has linked meetings with Pyongyang to discuss missiles and nuclear weapons and other issues, including conventional forces and the country's human rights record (Conachy 
2001; Gross 2001; Kerr 2003; Koppel and Labbot 2001; Perry 2001; LaMontagne 2002).

Pyongyang reacted violently to these proposed agenda, alleging that Washington officials were only trying to set a unilateral agenda for the talks, and declared that none of Bush's proposals were acceptable (Lea 2001).

On May 2002, Bush submitted to the Senate the additional protocol to the US-IAEA nuclear safeguards agreement. In his message to the senate, Bush urged early and favorable consideration of the agreement (Pickett and Purnell 2004), and stressed that the central goal of his nuclear proliferation policy is its universal adoption (Kucia 2003). While the original protocol was signed in 1998, the new protocol allows the IAEA to conduct short-notice or immediate inspections, and employ new environmental-sampling and satellite-monitoring techniques at any suspect site. Furthermore, the protocol required states to provide the IAEA with any additional information about aspects of their civilian nuclear programs, such as fuelcycle activity and nuclear-related exports. In actuality, the US ratification of the protocol primarily served to set a good example for those states that have yet to sign or ratify it. In March 2002, China notified the IAEA that it had completed its ratification of the protocol, thus becoming the only NPT nuclear-weapon state whose agreement has entered into force (Kucia 2003).

Meanwhile, a year after the 2001 terrorist attacks in the United States, the Bush Administration adopted a new National Security Strategy in September 2002, which included the government's new and continuing policy on preemptive action (Diehl 2002; Fein 2003). The unprecedented strategy stresses the necessity of preemptively attacking countries developing weapons of mass destruction, and in articulating its meaning, explicitly states North Korea as an example (Heginbotham 2003; Carlson 2003; Kerr 2003). In October 16, 2002, matters took a 
turn for the worse, when the United States announced that Pyongyang indirectly acknowledged its nuclear weapons development program (Lee 2002). James Kelly, assistant secretary of state for East Asian and Pacific affairs, who visited Pyongyang said that the admission was made the day after he informed the DPRK that the United States knew of the clandestine program. In response to the acknowledgment, to which the DPRK denied subsequently, the United States decided to stop supplying heavy oil to North Korea in November. In retaliation, North Korea refused to allow the KEDO delegation to enter the country to inspect the use of heavy oil (Lee 2002), and subsequently proclaimed the resumption of the construction and operation of all its nuclear facilities (Kim and Song 2002).

In November 2002, the IAEA adopted a resolution requesting North Korea clarify its reported uranium-enrichment program. Pyongyang rejected the resolution, alleging that the IAEA's position was biased in favor of American interests. The DPRK announced that it was reactivating the nuclear facilities it had frozen under the Agreed Framework since 1994, and ordered international monitors to leave the country. On January 6, 2003, the IAEA Board of Governors adopted another resolution, this time condemning North Korea’s decision to restart its nuclear reactor and related facilities in violation of the 1994 Agreed Framework, and calling on North Korean representatives to meet immediately, as a first step, with IAEA officials. Furthermore, it ordered North Korea to reestablish the monitoring equipment Pyongyang had dismantled, to comply fully with agency safeguards, to clarify details about its reported uraniumenrichment program, and to allow the agency to verify that all its nuclear material was declared and subject to safeguards. On January 10, 2003, North Korea announced that it was immediately withdrawing from the nuclear NPT, and condemned the second IAEA resolution because it infringed upon sovereignty. The main reasons for the withdrawal included: (1) the Korean 
Peninsula Energy Development Organization (KEDO) decision that it would suspend fuel oil deliveries to North Korea, and (2) the fact that Bush had labeled North Korea part of an axis of evil during his State of Union address. ${ }^{32}$

\section{Bush Administration's Policy Shift ${ }^{33}$}

Largely in response to the developments mentioned above, the Bush administration’s policy started to shift. In the beginning, the Unite States maintained that it would not engage in formal talks or negotiate with North Korea until it agreed to give up its prohibited nuclear programs. However, a meeting of the TCOG changed Washington's stance, and produced a statement saying that the United States was now willing to talk to Pyongyang about how it would meet its obligations to the international community. Table 5 summarizes the chronology of events that led to the Bush administration to adopt multilateral approach in resolving the North Korean nuclear threat. $^{34}$

\footnotetext{
${ }^{32}$ Paul Kerr has written numerous articles on North Korea and the Bush Administration's behaviors on the nuclear crisis. Kerr's articles used in this study appeared online in the Arms Control Today, which can be accessed at www.armscontrol.org.

${ }^{33}$ The following articles and books were used to examine the Bush Administration's policy Shift regarding the North Korean nuclear crisis: Boese (2004), Choi (2003), Daalder and Lindsay (2003), Dong-A Ilbo Daily (April 2000), George W. Bush Administration Policy Toward North Korea (2004), Hwang and Kim (2003), Kim (2003), Koh (2004), Korea Herald (April 24, 2003), Kucia (2003), Lee (2002), Lee and Feffer (2004), Niksch (2001), Seo (2003), and The Ministry of Foreign Affairs of Japan (2004).

${ }^{34}$ The sources used to construct the table on the timeline of the North Korean nuclear crisis were: Atomic Archive. 2005. "A timeline on nuclear weapons development in North Korea." http://www.atomicarchive.com/Reports/Northkorea/Timeline.shtml (August 1, 2005).

BBC News. 2005. “Timeline: N Korea nuclear standoff.” http://news.bbc.co.uk/2/hi/asia-pacific/2604437.stm (August 1, 2005).

Global Security. 2005. “Korea Crisis Countdown Timeline.” http://www.globalsecurity.org/military/ops/koreatimeline.htm (August 1, 2005).
} 


\section{Table 5: The Road to the Six-Party Talks in Beijing}

\begin{tabular}{|c|c|}
\hline Date & Nuclear Standoff \\
\hline October 4, 2002 & $\begin{array}{l}\text { NK reportedly acknowledged its nuclear weapons } \\
\text { development program when James Kelly visited Pyongyang }\end{array}$ \\
\hline October 25, 2002 & NK proposed a non-aggression pact with the US \\
\hline November 14, 2002 & KEDO announced the discontinuance of heavy oil supply to NK \\
\hline December 12, 2002 & The US declared the nullification of the Geneva Agreed Framework with NK \\
\hline December 16, 2002 & $\begin{array}{l}\text { Colin Powell assured North Korea that the US has no intention of attacking that } \\
\text { country. But he rejected the idea of a non-aggression treaty, which Pyongyang } \\
\text { is demanding to settle the crisis over its nuclear weapons program. }\end{array}$ \\
\hline December 27, 2002 & NK purged the IAEA inspectors from its territory \\
\hline December 29, 2002 & The US adopted a 'tailored containment' policy against NK \\
\hline January 6, 2003 & $\begin{array}{l}\text { Bush allowed the IAEA to take the lead on North Korea, and call for a meeting } \\
\text { of the UN Security Council to discuss the crisis. }\end{array}$ \\
\hline January 7-10, 2003 & $\begin{array}{l}\text { A trilateral meeting between South Korea, the US and Japan in Washington } \\
\text { was held as part of the allies' regular forum for coordinating policy toward the } \\
\text { DPRK. }\end{array}$ \\
\hline January 10, 2003 & $\begin{array}{l}\text { NK withdrew from NPT and announced they would not let UN nuclear } \\
\text { inspectors back into the country. }\end{array}$ \\
\hline February 5, 2003 & $\begin{array}{l}\text { North Korea says it has restarted its nuclear facilities at Yongbyon, adding to } \\
\text { the controversy over the country's nuclear ambitions. }\end{array}$ \\
\hline March 17, 2003 & $\begin{array}{l}\text { The US Ambassador to South Korea clarified that US policy } \\
\text { toward NK would be different from the case of Iraq }\end{array}$ \\
\hline April 07, 2003 & $\begin{array}{l}\text { NK dropped its demand for a non-aggression treaty with the US, stating that } \\
\text { "The Iraqi war shows that to allow disarming through inspection does not help } \\
\text { avert a war but rather sparks it... This suggests that even the signing of a non- } \\
\text { aggression treaty with the U.S. would not help avert a war." }\end{array}$ \\
\hline April 14, 2003 & $\begin{array}{l}\text { NK announced its acceptance of new multilateral talks for } \\
\text { resolution of nuclear problem }\end{array}$ \\
\hline April, 23, 2003 & Trilateral Talks (DPRK, USA and China) in Beijing, China \\
\hline May 05, 2003 & $\begin{array}{l}\text { Bush denied shifting its policy on North Korea's nuclear program to focus on } \\
\text { preventing that country from exporting nuclear weapons or material. }\end{array}$ \\
\hline July 12, 2003 & Chinese Vice Foreign Minister Dai Bingguo visited NK \\
\hline July 17, 2003 & Dai Bingguo visited Washington \\
\hline August 1, 2003 & NK agreed to participate in six-party talks \\
\hline August 27-29, 2003 & First Round of Six-Party Talks in Beijing, China \\
\hline February 25-28, 2004 & Second Round of Six-Party Talks in Beijing, China \\
\hline June 23-26, 2004 & Third Round of Six-Party Talks in Beijing, China \\
\hline July 26-Agust 6, 2005 & Fourth Round of Six-Party Talks in Beijing, China \\
\hline
\end{tabular}




\section{Bush’s Multilateral Strategy: Six-Party Talks}

Following Pyongyang's withdrawal from the NPT, the United States began promoting multilateral negotiations among the most concerned parties aimed at reaching a settlement through diplomatic means (George W. Bush Administration Policy Toward North Korea 2004). Initially, North Korea opposed multilateral talks, firm on its stand that the nuclear crisis was purely a bilateral matter between the United States and the DPRK. However, due to the increasing pressure from major powers, especially the United States and China, the DPRK agreed to three-party talks with China and the United States, in Beijing, on April 23, 2003.

North Korea eventually cooperated to sit in the negotiation table with the United States and China after the United States threatened to take the issue to the UN Security Council for economic sanctions if North Korea persisted in its refusal to participate in a multilateral talks with the United States and others. Also, prior to the trilateral talks, China had expressed its dissatisfaction with North Korea for its continuing provocations by favoring vote in the IAEA on reporting the nuclear issue to the UN Security Council on February 12, 2003. This was a clear message to North Korea that Beijing would consider forsaking its policy of support for Pyongyang if it went too far (Liu 2003: 353). Furthermore, in February 18, Chinese Vice Foreign Minister Wang Yi warned North Korean Foreign Minister Paik Nam-sun that any renewed provocation by the DPRK would harm its relations with the PRC (French 2003: A6). Also, for three days in early March 2003, China cut off crucial oil supplies to Pyongyang, sending Pyongyang a signal of Chinese determination to get some cooperation from the DPRK (Liu 2003).

The Bush Administration was also successful in arranging a multilateral forum when North Korea announced its intention to participate in six-party talks with the United States, 
China, South Korea, Japan, and Russia on its nuclear program in August 2003. For months, Washington had insisted that Pyongyang's illicit activities were a regional issue best resolved in a multilateral setting which also includes South Korea, China, Japan, and Russia (Daalder and Lindsay 2003: 15). US administration officials warned that North Korean nuclear capabilities included WMD production, which in turn could be made available to rogue organizations such as Al Qaeda (Niksch 2004). In a June 2004 report by the US National Commission on Terrorist Attacks upon the United States revealed that al-Qaeda was still pursuing its strategic objective of obtaining nuclear weapon.

Assistant Secretary of State for Arms Control Stephen Rademaker told the Conference on Disarmament (CD) in Geneva February 13 that, in the post-Cold War era, multilateralism is more important than ever. Later, at a briefing in Beijing on February 24, 2003, Secretary of State Colin Powell said that the problem of North Korea's nuclear weapons program is not just a bilateral United States-North Korean issue, but must be dealt with through a multilateral effort by interested countries. According to Powell:

The United States feels strongly that North Korea's actions pose a threat to regional stability and to the global non-proliferation regime...And we are prepared to address these with North Korea in a multilateral context in which China and other nations can participate. It is a matter for China, it's a matter for South Korea, it's a matter for Japan, it's a matter for Russia, it's a matter for the United Nations, the IAEA, and it is a matter for the United States (Office of International Information Programs, US Department of State February 24, 2003).

Prior to his trip to South Korea, Japan and China on February 21-25, 2003, Powell said in an interview in February 19 that the United States would continue to communicate to North Korea that the United States had no intention of invading it, instead, it was interested in helping North Koreans who were starving. Powell also said that direct talks with North Korea would only happen if they started with multilateral negotiations: 
[U]ltimately, we know that we will have conversations with the DPRK. We believe those conversations would be more effective and would provide a more lasting solution to the problem if they began in a multilateral framework and they included other nations (Office of International Information Programs, US Department of State February 19, 2003).

Starting April 2003, the United States and North Korea resumed contacts to ease the standoff over North Korea's suspected nuclear weapons program. The first instance of contact occurred during the trilateral talks between China, the United States and United States, held in Beijing on April 23, 2003 (Korea Herald April 24, 2003). James Kelly, the US assistant Secretary of State, and Wang Yi, the Chinese Vice Foreign Minister, attempted to persuade Pyongyang to completely dismantle its nuclear weapons program, but North Korea, through its representative Ri Gun, did not change position, and instead restated calls for a legally binding non-aggression pact with the United States, in exchange for its nuclear disarmament. Indeed, the incompatibility of the United States and North Korea, coupled with the absence of South Korea, severely restricted any positive outcome from the trilateral talks. However, and despite this lack of positive attendance, the countries that did attend the talks agreed to establish an extended multinational cooperative framework, with a view to resolving the North Korean nuclear problem in a more peaceful and systematic manner (Korea Herald April 23, 2003). Such an envisaged framework was eventually linked with the first round of six-party talks in August of 2003.

On August 27, 2003, six nations—China, the United States, Russia, Japan, South Korea and North Korea—gathered at a hexagonal table in Beijing for a three-day meeting to discuss the issue of North Korea's suspected nuclear weapons program. The meeting served as a forum for clarifying the positions between North Korea and the United States, though during the talks their mutually irreconcilable positions were further reconfirmed (Hwang and Kim 2003). For North 
Korea, the objective was to construct a new level of relations that would eventually lead to the normalization of ties with the United States, and more importantly to obtain economic rewards for giving up its nuclear program. Their demands included: (1) confirmation that the United States would shift away from its hostile policy; (2) a secure non-aggression treaty that would strictly and legally guarantee that neither of the two sides would resort to attacking one another by conventional means; and (3) that the United States agree to abandon its antagonistic position toward North Korea (Anti-Imperialist News Service 2003). The United States, however, was deliberately vague on what rewards it might bestow upon North Korea if it agreed to dismantle its nuclear weapons program in a verifiable and irreversible manner (Seo 2003: 3).

During the first round of the Talks, Pyongyang agreed to the eventual elimination of its nuclear program on the condition that the United States should willingly sign a bilateral nonaggression treaty and meet various other conditions, including the provision of substantial amounts of aid and a normalization of diplomatic relations. However, the United States rejected this proposal, insisting on a multilateral resolution to the issue, and refused to provide any benefits or incentives for North Korea to abide by its previous international obligations (George W. Bush Administration Policy toward North Korea 2004). Bush said he would be willing to consider a North Korean multilateral written security guarantee, if North Korea would accept complete, verifiable, and irreversible elimination of its nuclear weapons program. On November 13, 2003, senior North Korean diplomats, Kim Yong-ho and Kim Song-sol said that the DPRK was prepared to give up its nuclear programs. In exchange, the DPRK expected written security guarantees and compensation for economic losses suffered by a decision to halt construction of two light water nuclear reactors by KEDO in the North (Zarocostas 2003). 
At the talks, while Russia offered joint assurance with China to Pyongyang, and showed its intention to intervene as a principal actor in resolving the nuclear crisis (Koh 2004), Japan's main concern was to solve the kidnapping of the Japanese by North Korea, as well as to maintain its security from the suspected nuclear weapons and missiles of North Korea (The Ministry of Foreign Affairs of Japan 2004). Kim Jong-Il admitted that his government agents abducted 13 Japanese nationals, in the late 1970s and early 1980s, eight of whom reportedly died. Five survivors have been allowed to return to Japan. The abduction issue almost overshadowed the nuclear crisis issue (Hanson 2004). Finally, South Korea reconfirmed its position as the most important counterpart of North Korea, and hoped to enforce a non-nuclear Korean peninsula plan (Seo 2003: 3). South Korea hoped that the success of the multilateral talks would translate into a more permanent peace regime between the two Koreas.

The first round of the six-party talks failed in resolving the North Korean nuclear crisis, as the participating nations were unable to adopt a joint statement or to make any significant breakthroughs. However, the six-party talks did open the gate for further meetings, and proposed the following objectives: (1) the resolution of the nuclear issue through peaceful means and dialogue; (2) addressing security concerns of the DPRK; (3) refrain from taking any action that may aggravate the situation while the process of negotiations is under way; (4) taking a parallel or simultaneous step in resolving the standoff; and (5) the continuation of the six-party talks, and the specific date and venue should be decided through diplomatic channels as soon as possible (People’s Daily 2003).

On February 25-28, 2004, the second round of the six-party talks was held in Diaoyutai, Beijing. In this round, North Korea maintained that it was disappointed over the United States’ stand because it did not show any stand to co-exist with North Korea; instead, the U.S. was 
determined to pursue their policy of isolating and stifling the DPRK, according to a spokesperson of the DPRK's Foreign Ministry (Korean Central News Agency February 29, 2004). The spokesperson added that North Korea showed willingness to scrap its nuclear program in accordance with a proposal for a simultaneous package solution aiming to denuclearize the Korean Peninsula. The United States, however, was adamant on its previous stand that unless the DPRK first abandons the nuclear program completely, verifiably and irreversibly, the US would not discuss the issues concerned by North Korea.

The second round of the six-party talks resulted to the reaffirmation of all the parties of the denuclearization of the Korean Peninsula as their common goal. They also agreed to address the nuclear issue in the form of coordinated steps. However, because of individual differences in the position of the six parties, the following issues remained outstanding, leaving the future development unpredictable: Japan, the United States and the ROK called for the CVID of all nuclear programs by the DPRK, but the DPRK claimed that peaceful uses of nuclear energy should be allowed and that dismantling should be limited to the nuclear weapons development program: Japan, the United States and the ROK emphasized that the DPRK should admit the presence of the uranium enrichment program, but the DPRK denied the existence of such a program.

The six parties held the third round of the Talks in Beijing on June 23-26, 2004 at Diaoyutai in Beijing. In this round, the resolution of the North Korean nuclear issue remained a difficult task for the six parties, especially for the Bush Administration. At the end of the Talks, the DPRK's position was strengthened and the United States position weakened despite their settlement proposal of June 23, 2004 (Niksch 2005). The United States demanded to North Korea to dismantle all its nuclear programs in a complete, verifiable and irreversible way; to 
place under international control all its missile materials; and to return IAEA inspectors to the country. In return, the United States would agree to the resumption of heavy fuel oil deliveries to North Korea by Japan and South Korea and offer provisional security guarantees. However, North Korea wanted to see those moves in return for a freeze of its nuclear programs, before dismantling them. North Korean negotiators also demanded that the United States lift all sanctions against the country and remove North Korea from the list of state sponsors of terrorism.

According to Larry A. Niksch, a specialist in Asian affairs, the United States’ proposal did not weaken the DPRK's position because, in reaction to the June 23 proposal, South Korea, Japan, China, and Russia encouraged the DPRK to adopt tactics not in accordance with the US position: the other parties supported the DPRK's reward for freeze proposal and its denials that it had a secret uranium enrichment nuclear program.

For one, Colin Powell's visit in late October 2004 drove Chinese and South Korean foreign ministers to make statements that implied their criticism of the June 23 proposal of the U.S. Moreover, as regard for the reward for the proposal for freezing nuclear facilities, the ROK, Japan, China, and Russia were skeptical about the claim of the US that North Korea was having a clandestine uranium enrichment program. With these, it can be argued that North Korea continued to refuse to participate in the fourth round of the talks because it believed that it can receive benefits from other parties’ payoff, especially from China which has continued to give money, food, and oil to get the DPRK on the Talks chair (Niksch 2005). The problem with the Bush administration, according to Niksch, was that it did not have an effective post-June 23 follow-up strategy to promote its proposal into a position of a basis for negotiations in the talks. 
Niksch has identified five major issues that the US faces regarding the future of the talks and policy toward the DPRK: (1) whether North Korea will agree to another meeting; (2) the issue of the price of getting North Korea to attend another meeting; (3) whether North Korea will admit it has a uranium enrichment program and will continue to demand acceptance of its “reward for freeze” proposal; (4) how to treat North Korea’s demand that the six party talks take up the South Korean nuclear activities, which the IAEA is investigating; and (5) US policy decisions if there were no further six party meetings or if future meetings produce no movement toward a satisfactory settlement.

The outcomes of the three rounds of the Six-Party Talks nevertheless showed that China gained the most, as it was outstanding as a host, and tried diligently to facilitate unofficial bilateral contacts between North Korea and the United States. China also attempted to forge a consensus among the participants, which resulted to China as emerging as the more assertive diplomatic power. The United States partially obtained the basic objectives that it had desired. The primary goal of the United States was to settle the North Korean nuclear issue within the multilateral frame (Kim 2003). A multilateral channel could also be an efficient measure for the United States' policy towards China. For Japan and Russia, the opportunity to participate in the multilateral negotiations was beneficial, and may also be viewed as an accomplishment in its own right (Koh 2004). South Korea confirmed its position as a main counterpart of North Korea. In general, however, North Korea was not satisfied with the outcome of the talks. It was supposedly disappointed with China and Russia, and its proposal to exchange an expression of its goodwill to the United States was refused (Koh 2004).

Supporters of multilateralism assert that gains can accrue to the United States through cooperating with other states. The United States is indeed better off achieving international 
objectives when possible through cooperative means, and situations that offer win-win payoffs should always be pursued. Moreover, the codification of cooperative practices in international treaties and institutions oftentimes can lock into place mutually beneficial arrangements, and indeed, American national security is best served when United States leaders are active in shaping the agenda of multilateral institutions. Finally, the multilateral perspective helps analysts and policymakers understand some state-to-state interactions.

\section{Rewards, Sanctions and Diplomacy}

While announcing support of engagement policy, the Bush administration has clearly shown that it wants "more quo for its quid" (Lee and Feffer 2004: parag. 8). North Korea’s compliance with the Bush administration’s aggressive strategies may yield rewards, perhaps substantial ones such as the normalization of relations and a large aid package.

Despite continued doubts concerning feasibility, cost, and adherence to the 1972 AntiBallistic Missile Treaty, the Bush Administration continues to make missile defense its strategic priority. The American stance on this issue was opposed by Russia and China. However, South Korea is clearly concerned that the United States defense policy might endanger engagement with the DPRK. While the unification of North and South Korea has been the focus of South Korean foreign policy, for the Bush administration peninsular reconciliation ranks rather low on the scale of US national interests. Recognizing that North Korea is in bad economic shape, Kim Dae Jung has not insisted on the "strict mutualism" and reciprocity that Bush is seeking, as some South Koreans fear that the Bush administration's approach will hinder their own efforts toward reconciliation (Lee and Feffer 2004).

In attempting to address the North Korean nuclear problem, the Bush Administration and its allies have discussed the possibility of imposing a number of economic and trade sanctions. 
However, economic sanctions may not be successful, nor would they cause the DPRK to change its political behavior. Indeed, North Korea is now less likely to be adversely effected by economic sanctions to be imposed by the Bush administration because it has alternative trading partners, a command economy, and is less dependent on foreign trade than other countries. Although commonly perceived as an economic hermit, North Korea actually has engaged in substantial trade with the rest of the world. In fact, North Korea engages in trade with most major nations, including China and Japan and most industrialized European countries (Kim, 2004). The continued and extensive trade of North Korea with China and Japan has thus relieved a great deal of the pressure applied by the United States sanctions and undercut their effectiveness. The Bush administration's stick strategy is further diluted by the status of North Korea as a command economy. In North Korea, the state controls the means of production and sets the priorities and emphases in economic development. Yi (2002) explains that because most of the transactions in North Korea occur between state-owned enterprises, this leaves the state the opportunity to perform its economic guidance function, including systematic distribution, thereby guaranteeing state control of the economy.

The result of any economic sanction is that although the general population feels the ensuing shortages, most citizens are unable to observe the direct link between sanctions and any hardships induced by them. Moreover, North Korea's population is less dependent on foreign trade. The North Korean philosophy of juche, or self-reliance, seeks to maintain neutrality, and demands complete independence in foreign relations. Against this background, the Bush Administration's imposition of economic sanctions is less likely to be effective because North Korea has prepared for economic isolation over several decades and there is not a great demand for foreign commodities by the general population. However, there have been significant 
changes in the characteristics of the North Korean economy since the announcement of July 1, 2002 economic reform measures by the Kim Jong Il government. Thus, contrary to the initial thinking, the DPRK may yield to economic sanctions imposed upon by the United nations, the United States, and its allies. The vulnerability of North Korea to economic sanction is reflected by the repeated warning of the Kim Jong-Il regime that the imposition of economic sanctions will be regarded as "the declaration of war."

Considering the complexity of the North Korean situation, some observers have advocated the use of both carrots and sticks in resolving the North Korean nuclear problem: for carrots without sticks would end up as an appeasement policy associated by many with the Clinton Administration's policy, while sticks without carrots would result into unnecessary loss of lives. A right combination of such strategies would be more effective than any other multilateral measures pursued by the Bush administration (Choi 2003).

\section{International Regime}

From April 28 to May 9, 2003, more than 100 state-parties included in the NPT Preparatory Committee (PrepCom) met to confront the myriad of nuclear threats. In this meeting, they upheld the nuclear NPT as "the cornerstone of the global nonproliferation regime and the essential foundation for the pursuit of nuclear disarmament” (Kucia 2003: parag. 1). The PrepCom proceedings for the 2005 NPT Review Conference were dominated by proliferation concerns, with countries stressing ongoing problems with Iraq, newfound allegations of an extensive nuclear program in Iran, and North Korea’s destabilizing withdrawal from the treaty.

The discussion on North Korea's withdrawal could not be helped at the gathering, despite attempts by PrepCom Chairman László Molnár of Hungary to minimize its impact on the meeting. Russia, the United Kingdom, and the US were unable to agree on how to handle North 
Korea’s status upon its January 10, 2003 withdrawal date and, therefore, the UN could not address the issue prior to convening the PrepCom. Moreover, divisions between the member parties themselves occurred, as they debated on whether to even acknowledge North Korea's withdrawal or to overlook it. Delegates were obviously dismayed at North Korea’s announcement, and they stressed the need for a peaceful and diplomatic solution to the crisis on the Korean Peninsula. Hubert de la Fortelle, the French permanent representative to the Conference on Disarmament, went a step further, remarking on April 28, 2003 that, “naturally, a clear commitment is also needed from the UN Security Council with a view to contributing to a peaceful resolution to the crisis” (Kucia 2003: parag. 7). Delegates underlined their concerns about US actions, which suggested that nuclear weapons development might be at hand, and that the administration was considering revoking its “negative security assurances” or nuclear nonuse pledges, made in the context of the NPT (Kucis 2003). The United States first formally made “negative security assurances” in 1978. Secretary of State Warren Christopher announced a somewhat revised policy on April 5, 1995, which was repeated on February 22, 2002 by State Department spokesman Richard Boucher (Kimball 2002).

On March 15-18, 2004, Bush and top officials from the CIA and the Departments of Energy and State, and members of the Congress met to discuss possible proposals for remedying the ailing nonproliferation regime. Probable revisions discussed at the meetings included cleaning up and securing weapons-usable material worldwide, strengthening export controls, and denying uranium-enrichment and plutonium reprocessing technologies to states that do not have them (Boese 2004). From April 26 to May 7, 2004, PrepCom convened again, in order to come up with necessary actions to be taken to fine-tune the NPT. 


\section{The Effects of Domestic and Systemic Constraints on Bush Policy}

\section{Domestic Constraints}

Table 6 summarizes the domestic constraints — the US Congress and the Senate,

American culture and public opinion, and the bureaucratic government. ${ }^{35}$

Table 6. Domestic Constraints (Bush Administration)

\begin{tabular}{|c|c|}
\hline Variables & Impacts on Bush’s Policy \\
\hline $\begin{array}{c}\text { US Congress and US } \\
\text { Senate }\end{array}$ & $\begin{array}{l}\text { - Despite the great divide between Republicans and Democrats, } \\
\text { the Congress and the Senate have generally supported Bush’s } \\
\text { policy } \\
\text { - Republicans prioritized the bolstering of US deterrence and } \\
\text { military capabilities, particularly nuclear weapons } \\
\text { - Democrats advocated diplomatic solutions and decreasing US } \\
\text { reliance on nuclear weapons. } \\
\text { - Democrats stressed multilateral and bilateral negotiations, } \\
\text { including "direct and immediate talks with North Korea" } \\
\text { - Democrats feared military actions may provoke other } \\
\text { countries }\end{array}$ \\
\hline American Public Opinion & $\begin{array}{l}\text { - The American public supported Bush's policy on NK } \\
\text { - The public began to see terrorism and nuclear proliferation as } \\
\text { a direct and imminent threat } \\
\text { - The general public agreed that it would be best for the future } \\
\text { of the US to take an active part in world affairs }\end{array}$ \\
\hline Bureaucracy & $\begin{array}{l}\text { - There has been a debate within the Bush administration } \\
\text { regarding its policy toward NK } \\
\text { - Pentagon hawks viewed regime change as the most ideal, } \\
\text { effective, and enduring solution } \\
\text { - The moderates argued that talks with NK would result to a } \\
\text { negotiated settlement and would build a coalition among } \\
\text { concerned countries for taking action if engagement fails }\end{array}$ \\
\hline
\end{tabular}

\section{United States Congress}

One of the most important factors that has influenced the Bush Administration's policy toward North Korea, is the apparent support given by the US Congress. As discussed earlier, the Clinton administration had experienced challenges and criticisms especially from the Congress

\footnotetext{
${ }^{35}$ The discussion of the influence of the domestic constraints on the Bush Administration is derived from the following: Bock (2002), Boese (2003), Cha (2004), Cossa (2001), Lindsay (2003), McFaul, (2002), and Reiss (2004).
} 
(Elder 2003), which forced them to conduct extensive bargaining especially with Congress to solicit support. These domestic challenges almost vanished during the Bush administration (Cossa 2001; Reiss 2004) as, first, the Congress supported his choice of strategies in different foreign policy issues, and second, the Congress allowed Bush to wage two foreign conventional wars, one on terrorism, and the other against Iraq (Bock 2002; Newsmax.com Wires, 2002). Moreover, it supported the decision to withdraw from the 1972 Anti-Ballistic Missile Treaty (ABM), in order to develop an expensive new missile defense (McLaughlin \& Associates, 2001). However, in March and April 2003, Republican and Democratic legislators started to reveal severely different visions on how best to prevent the continuing proliferation of nuclear, chemical, and biological weapons (Boese 2003). Republicans put priority on the bolstering of US deterrence and military capabilities, particularly with regard to nuclear weapons. The Democrats, on the other hand, stressed the importance of seeking diplomatic solutions and decreasing US reliance on nuclear weapons. A House Republican Policy Committee report released on February 13, 2003, the committee declared that nuclear weapons and deterrence continued to be just as relevant in the present as they had been during the height of the Cold War. The report argued that for nuclear weapons to retain their role as a credible deterrent, American nuclear capabilities should be overhauled, by reducing the time needed to conduct a nuclear test explosion by half. The report called for further research in to new types of nuclear weapons in part of discover and destroy deeply buried targets, as well as modernizing and preserving the American nuclear stockpile, and recommended that the US tackle different types of nuclear weapons in toder to enable it to threaten a variety of targets.

Senate Democrats, however, had a different view. Senate Minority Leader Tom Daschle (D-SD) submitted a resolution, dated March 5, 2003, and on behalf of himself and 30 fellow 
Democratic Senators, plus independent Senator Jim Jeffords, recommending the United States to move away from the increased reliance on the importance of nuclear weapons. The resolution called on the Bush administration to develop a strategy that stressed multilateral and bilateral negotiations, including direct and immediate talks with North Korea, in order to strengthen international controls and nonproliferation norms (Boese, 2003: 1). Democrats disputed the notion that other countries might become more motivated to acquire nuclear weapons if they perceived the United States as assigning expanded roles to nuclear weapons or increasing its willingness to use them. In general, Republicans sought a foreign policy that was reliant on internal intelligence and technological capabilities, in order to "overtly and covertly" disrupt proliferation activities, while the Democrats recommended negotiating a protocol to block shipments of such weapons and delivery systems (Boese, 2003: 1)

\section{American Public Opinion}

Similar to the Congress, the American public showed support of the Bush administration's foreign policy programs, including the war on terrorism and the drive against the proliferation of weapons of mass destruction. The American public had been critical of the Clinton administration for being inexperienced and having misguided policy priorities. More importantly, the public criticized Clinton for the weakening US defense through budget cuts and re-deployments, and for making the United States appear weak against North Korea and for giving in to the latter's demands. The shift in the public's attention, from local issues to global and foreign concerns, as well as with regard to the Congress, interest groups, and other domestic institutions, can be largely attributed to the September 11 terrorist attacks. Indeed, following this single event, foreign policy concerns became the top priority for the public. While the public had been more concerned with domestic issues, such as health and livelihood programs and defense 
spending, prior to the attacks, they now began to apprehend the serious threat posed from the outside. They began to see terrorism and nuclear proliferation as a direct and imminent threat, and not just a foreign policy concern of the President, and they shifted their priorities and began seeing foreign policy as their concern too. Bush's axis of evil speech, with the help of the mass media, especially cable news (CNN, Fox) changed the public's perception about terrorism and nuclear proliferation and they began supporting President Bush and his administration.

Following the attacks, and to illustrate the extent to which public opinion had been affected, President Bush gained a 90\% approval rating, higher than any president achieved before, and public opinion centered around supporting Bush and his War on Terror. One year after the attack, his approval stood at 70\% (Lindsay 2003: 539). A November 2001 poll resulted in 81 percent of the polling population agreeing that it would be best for the future of the country to take an active part in world affairs (Lindsay 2003: 539). Instead of calling for isolation from world affairs, the public began supporting engagement to the world. More than $77 \%$ of Americans see the current government in North Korea as a great or moderate danger to Asia. American public concern has risen by 12 percentage points since November 2002 (The Pew Global Attitudes Project 2003).

\section{Bureaucratic Politics}

There has been a debate within the Bush administration regarding its policy toward North Korea. At one end of the debate are the Pentagon hawks who advocate regime change as the most ideal, effective, and enduring solution. Maureen Dowd of the New York Times identified US Vice President Dick Cheney, US Deputy Defense Secretary Paul Wolfowitz, the Defense Policy Board, and the US Undersecretary of State for Arms Control, John Bolton as members of the hawkish camp led by US Secretary of Defense Donald Rumsfeld (Cha 2004). On the other 
side of the debate are the moderates who include Director of Policy Planning Richard Haass, most of the US Foreign Service, US Senator Joeseph Biden, political journalist Bob Woodward, and many in the liberal media and academic elite. This group can be viewed as being led by Colin Powell, who believes that the disarmament of North Korea is best achieved through continued diplomacy. Moreover, the moderates do not believe that US engagement will change North Korean intentions, yet they argue that talks with Pyongyang will result in a negotiated settlement, and help build a coalition among concerned countries for taking action if engagement fails (Cha 2004: 75). The debate started during the trilateral talks as discussed earlier involving the United States, China, and North Korea. Pyongyang's 11th-hour threat to reprocess plutonium led to vigorous internal debates about possible countermeasures. Whereas the moderates advocated a continuation of the talks, the hawks opposed US attendance (Cha 2004: 76). Although both groups agreed that North Korea's blackmail attempts were intolerable, and that Pyongyang needed to come clean on its nuclear weapons programs before any form of engagement can be considered, they differed in their definitions of coming clean. That is, while the hawkish group demands total disarmament before serious engagement, the moderates consider more flexible requirements for negotiations to start.

Realist ideology, when applied to the making of Bush policy towards NK, must preserve the status quo, and avoid active engagement in the domestic affairs of other states. However, this prescription cannot be adopted by the United States, as, instead of maintaining the current world order, American foreign policymakers have been revising the current international system and the states that constitute it. This is because the current order is not safe for the United States, and pragmatic inaction will allow the current order to become even more threatening to the United States and its allies (McFaul 2002). From this perspective, the Bush administration's much- 
maligned emphasis on multilaterally approaching North Korea may make sense. If Kim wants both bilateral negotiations and a nuclear arsenal, the only way of dashing his hopes is for interested regional parties to tell him that he simply cannot have both. The multilateral approach has been the United States preference, and it now appears to be Russia's as well, given recent statements by Moscow that a nuclear North Korea would prompt reconsideration of its policy opposing sanctions against the nation. It also appears to be the preference of both Japan and China, given the residual outrage among Japanese citizens over the abduction of Japanese nationals by North Korean operatives during the 1970s and 1980s, as well as Beijing's growing frustration at their communist ally's insolence and incompetence (Cha 2004: 75). It is clear that the above domestic factors have significant contributions to the Bush Administration's policy on North Korea. Figure 5 is a simplification of the domestic constraints and their effects on Bush administration’s policy towards North Korea.

In summarizing the impacts of domestic factors on the Bush administration policy, the support given by the US Congress, as well as the US Senate and other domestic institutions, on the Bush administration's policy toward the DPRK, has strengthened the United States' stand on the North Korean nuclear crisis. Based on this, it is likely that the current multilateral approach will shift to a combination of multilateralism and bilateralism during the end of the Bush's second term. In addition to the multilateral agreements in the continuing Six-Party Talks, it is expected that the United States will enter into a bilateral negotiation with North Korea.

Moreover, the American public has generally advocated the Bush administration's stance on the DPRK, as they perceive North Korea to be a serious threat to Asia, as well as a potential one to the United States. This may further boost the administration's current stand of employing military forces and economic sanctions. Finally, bureaucratic problems, as illustrated by the 
ongoing debate between the Pentagon hawks and the Powell group, may change Bush’s policy toward the end of his administration. The multilateral approach, the stick strategy, and the exclusion of the international regime will remain the same. However, the expected changes will be influenced by systemic pressures, especially from North Korea, South Korea, China, Japan, and Russia.

Figure 5. Impact of Domestic Constraints on Bush’s Policy

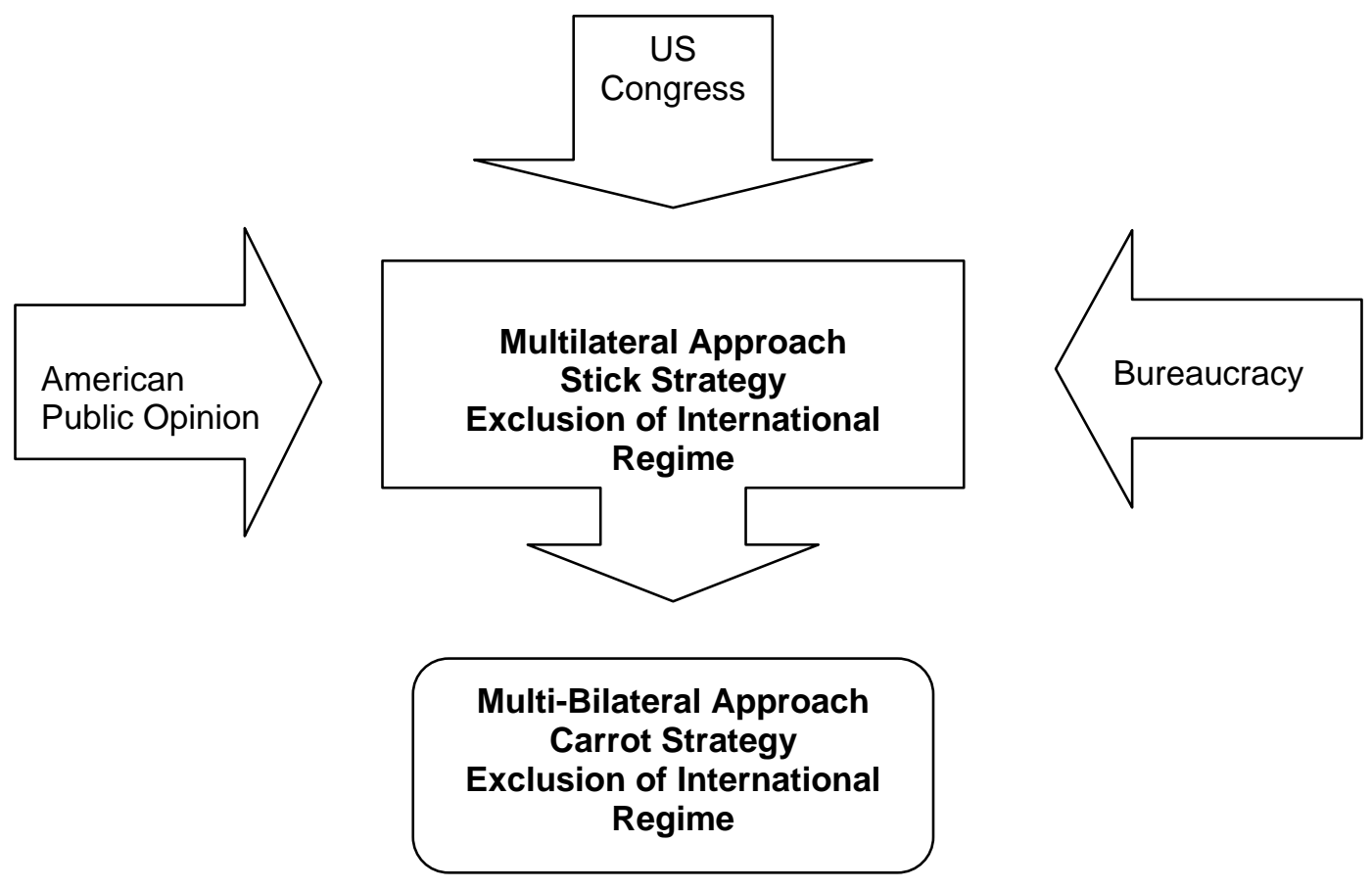

\section{International Systemic Constraints}

Systemic constraints in the Bush administration consist largely of the seemingly fragmented cooperation and inconsistency between the United States and other parties such as South Korea, China, Japan and Russia. The differences have been in the policy orientation within countries themselves, the program for action, and the inability of the countries to cooperate. All of these actors broadly share US concerns and goals, but had preferred a low-key approach for various reasons. Policy options of the Bush Administration were limited because economic, 
political and military approaches could work best only if these allies cooperated with the Bush

Administration. Table 7 summarizes the systemic constraints faced by the Bush Administration.

Table 7. Systemic Constraints (Bush Administration)

\begin{tabular}{|c|c|}
\hline Variables & Impacts on Bush's Policy \\
\hline $\begin{array}{l}\text { Inconsistencies between US and } \\
\text { other foreign policies on NK }\end{array}$ & $\begin{array}{l}\text { - In terms of economic sanctions, China’s policy does not } \\
\text { - } \quad \text { China will fight for, not against NK should a war broke } \\
\text { out between US and NK } \\
\text { - } \quad \text { Bush’s policy is irreconcilable with South Korea’s } \\
\text { Sunshine Policy } \\
\text { - } \quad \text { Roh-Moo Hyun will be the greatest challenge in pursuing } \\
\text { - } \quad \text { Rush’s “hostile” policy } \\
\text { - } \quad \text { Russia prefers less confrontational approach } \\
\text { - } \quad \text { Japan generally supports Bush's policy } \\
\text { - } \quad \text { Japan considers unilateral economic sanctions }\end{array}$ \\
\hline The Kim Regime & $\begin{array}{l}\text { - The Kim regime views the Bush administration policy as } \\
\text { flawed } \\
\text { - NK has repeatedly cited Bush's "hostile policy” as } \\
\text { justification to its nuclear program }\end{array}$ \\
\hline
\end{tabular}

After the tragedy of the September 11 attacks, Bush has taken the pledge of protecting the world from grave threats of terrorism. North Korea's confession that it was currently conducting nuclear-related activities prompted the Bush Administration to publicly revile North Korea as a threat to the world's safety. Bush's consideration of North Korea as one of the axis of evil was taken by North Korea as a "little short of a declaration of war" and warned it was undertaking the necessary defensive preparations (Conachy 2002: parag. 4). In this vein, Bush also faces what has been the gravest challenge of Clinton’s struggle to negotiate with Pyongyang. The Bush administration has been in no better position than the Clinton administration in beseeching the impeccable support of China, South Korea, Japan, and Russia over its policy on North Korea.

It is expected that with the confirmation of support from these countries, the implementation of Bush’s economic, political, and military policies and programs for North 
Korea are likely to succeed. All of these countries support US feats to minimize, if not totally stamped out, threats against mankind's security. But these countries still remain reserved over the issue of whether to accept Bush hard line policies against North Korea. Years ago, Clinton’s much softer approaches also beget the same coldness, which was largely condemned as the main reason for its failure (Eichensehr 2001: 11-12). The United States attempts to dismantle the nuclear program in North Korea will not succeed unless supported by major powers in East Asia. For instance, in order to implement its economic sanctions on the country, the United States would need the support of China, as North Korea remains heavily reliant on China economically (The Economist May 1, 2003). Should the trading activities continue between these two countries, any effort to impose economic pressure on North Korea is not likely to lead to the decision to stop North Korea from pursuing its nuclear-related interests. Furthermore, without China's support to the US, North Korea could still rely on its trading partner for its supply of basic necessities and fuel. Thus, it is a must for US to get China on its side.

Overall, things are going well in favor of the Bush Administration. In line with the consensus on the opinion that the development of nuclear activities and programs in North Korea which is an imminent danger not only to neighboring countries but to the world at large, Bush administration's struggle to launch a multilateral support on dismantling these nuclear activities in the country proves to be advantageous to all concerned countries. This is despite the fact that target partners in East Asia are still reluctant to some of the Bush administration's hard line policies on NK (Tkacik 2003). Lately, however, with the progress of the six-party talks and the softening of the Bush policy on the DPRK, South Korea, Japan, China, and Russia are beginning to fully cooperate with the United States. 
Before, the Bush Administration was having a hard time in enlisting the support of countries involved in the six-party talks because each of these countries tended to have its own remedy to address the issue. China, being the closest ally of the country refused to accept the principle of war or economic sanction as the sturdy solution to the problem (Ji 2001: 396). In the same fashion, Russia opposed the use of military or economic policy to resolve the issue. Meanwhile, South Koreans viewed with alarm the Bush Administration's hard line policies of confrontation that were in contrast to the principles of Sunshine Policy (Rowen 2003).

It seemed, however, after the third round of the Talks, that the Bush administration was beginning to take the long and patient process of resolving these differences. With this strategy, it is now more likely that the major East Asian powers will adhere to the United States' policy principles toward the DPRK. Essentially, Bush implements policies that are generally unilateral in orientation. This approach complements the needs for a multilateral consensus that Bush is espousing.

One thing is clear. South Korea, Japan, China, and Russia are in agreement with the United States regarding the goal of maintaining nuclear-free Korean peninsula. As such all of them are opposed to the proliferation of nuclear weapons by the DPRK in Korea. Even China and Russia want North Korea to abandon its nuclear weapons program. Also, these superpowers support the six-party talks to settle the North Korean nuclear weapons issue. This is why all of them urge North Korea to return to the Talks as soon as possible. It is true that South Korea, China, and Russia do not want any coercive actions to be taken by the United States to resolve the crisis. 


\section{Consensus-Building with South Korea}

South Korea poses a problem to the United States by putting an essential restraint to any potential multilateral strategy by the Bush administration for the South Korea's role in the US policy implementation in NK. However, one of the several drawbacks of Bush Administration's formulation of foreign policy has been its failure to consider how its own policy would fit relative to the policies of other states. The Bush team failed to account how the deterioration of the Agreed Framework would influence the North and South Korean governments. Contrary to what the Bush team has estimated, North Korea did not as much as flinched with the collapse of the Agreed Framework. The Bush Administration had earlier assumed that North Korea would comply with its desires after its supply of fuel halted. However, North Korea took a methodical response of reviving its nuclear reactor to sustain its needs leaving the administration to bellow on its own cause. Soon after the United States proposed its hard line policies on North Korea, the country pull out from the NPT as a retort.

Furthermore, the United States had difficulty taking South Korea on its side. It was believed that President Roh-Moo Hyun would be the greatest challenge of the Bush administration in pursuing its hostile policy against North Korea. Roh joined the effort of the former two South Korean leaders in their campaign to oppose any military or economic sanction against NK. Roh was a renowned advocate of the Sunshine Policy, and South Korea perceived that the hard line policies of Bush were complete contrasts of the principles of Sunshine Policy (Rowen 2003).

Under the Sunshine Policy, South Korea assured North Korea against the possibility of the former absorbing the latter. Furthermore, the agreement facilitated North-South contact and cooperation. Kim Dae Jung strongly urged the United States to support this policy (Rowen 
2003). Indeed, United States had difficulty convincing South Korea to modify its own policy

(Quinones 2003: 198-199; Chung 2001: 4; Kim 2001).

Initially, Bush turned a cold shoulder towards the Sunshine Policy. But later on, he periodically released statements of support for the Sunshine Policy (Kim 2001: 9-20; Chung 2001: 4). He supported South Korea’s proposals to build a railroad and road across the demilitarized zone, assist North Korea in flood-control of Imjin River, investment guarantees for South Korean firms investing in North Korea and reuniting separated Korean families. The relationship between the US and South Korea regarding the North Korean nuclear problem improved since the two countries entered the multilateral process in August 2003.

\section{Consensus-Building with China}

If Bush successfully solicits the unsullied support of China, Bush foreign policy on North Korea would be more likely to progress. This assumption gained support from the fact that North Korea is one of the known economic recipients of China (Pomfret 2003: A16), and the Bush Administration has assumed this, as well as China's close political, economic, and security ties with Pyongyang.

John J. Tkacik, Jr., a research fellow in China Policy in the Asian Studies Center at The Heritage Foundation, advised that US negotiators must have a clear-eyed view of China's role in the North Korean nuclear crisis: (1) China will act in its own self-interest, and China's interests diverge from America's and (2) China clearly wants the United States to support North Korea economically to ease the costs on China and urges United States diplomatic recognition and a nonaggression pact to legitimate the existence of China's client state--the world's most terrifying dictatorship (Tkacik 2003). 
China made its position over the matter even more apparent during the US-China-DPRK talks on April 23, 2003. Despite China's promise of neutrality, the US was aware that Beijing was not neutral in the North Korean nuclear problem (Tkacik 2003). While the US insisted on multilateral talks, preferably in the United Nations, the PRC wanted direct bilateral talks between Washington and Pyongyang. Although China declared it was for the denuclearization of North Korea, China's consistent position remained (Ministry of Foreign Affairs of the PRC 2003): it had no information that the DPRK was actually developing nuclear weapons; it would not criticize North Korea's statements that it was not developing nuclear weapons; and the United States must accommodate North Korea's needs. Hence there was low probability that China would do anything to impede North Korea's future in the international arena.

In reality, however, China has taken neutral stance on the issue, which is doing the Chinese economy a favor. After the disintegration of the Soviet Union, China had assumed the top position as the North Korean’s leading economic benefactor (Tkacik 2002). Thus China has taken a soft approach toward North Korea and its economy, refusing any kind of economic curtailment in the country. According to some analysts, China would want to prevent war to escape the exodus of North Koreans casualties and the responsibility to cater to the needs of the war times (Hayes 2003).

Before, China was reluctant to align its policies with US and other East Asian countries; however, it was using its own channels of communication to discourage nuclear programs in North Korea. In general, China wanted the nuclear disarmament of the DPRK. In fact, in a bilateral meeting with Russia, China expressed the importance of maintaining "the non-nuclear status of the Korean peninsula and the regime of non-proliferation of weapons of mass destruction" (Laney and Shaplen 2003: 21). China then was hanging on the possibility that the 
United States may keep its doors open for any diplomatic consultations from other East Asians countries. Conditions improved between China and the United States and other East Asian countries with the undertaking of the six-party talks.

\section{Consensus-Building with Russia}

Russia takes a similar position to China over the North Korean issue. This is because, like China, Russia is a major training partner with, and provider of foreign aid to North Korea. Thus the United States is also calling for Russia to exert more pressure towards North Korea. However, like China, Russia has expressed a preference for a less confrontational approach, and has announced that it would not support sanctions yet (Zaks 2002). One of the reasons is that Russia and North Korea regained confidence in each other, soon after President Valdimir Putin’s election. Russia, like China, wants nothing but peaceful ties with Pyongyang. Recently, it has been rumored that North Korea has solicited technical assistance from Moscow for the development of a nuclear reactor for the nation. As of May 2002, Russia reportedly was discussing possible avenues of military technical cooperation with the DPRK (Zaks, 2002).

Russia from the very beginning has been vocal about the counter proliferation of weapons of mass destruction. Russian president Vladimir Putin has voiced out the country’s denunciation of North Korea's nuclear program. In a bilateral meeting with Japanese Prime Minister Koizumi in January 2003, Putin exhibited a disappointment and profound concern regarding Pyongyang's decision to withdraw from the NPT. Furthermore, Putin and the other leaders attending the June 2003 G-8 Summit, in Evian France, declared that, "North Korea's uranium enrichment and plutonium production programs and its failure to comply with its IAEA safeguards agreement undermine the non-proliferation regime and are a clear breach of North Korea's international obligations,” and strongly urged North Korea "to visibly, verifiably and 
irreversibly dismantle any nuclear weapons programs" (see Declaration on the Proliferation of Weapons of Mass Destruction 2003).

Russia's stance on the nuclear crisis is made evident in its participation in the three rounds of the multilateral process involving the United States, North Korea, South Korea, Japan, China, and Russia. After the first round, Russia urged the DPRK to end provocative measures that might worsen the crisis. In the second round, Russia proposed a comprehensive package deal to address the nuclear crisis: Pyongyang should abandon its military nuclear program in exchange for security guarantees and assurances of noninterference by Washington.

While the United States demanded that the DPRK eliminate its nuclear programs all at once, Russia believed that it was more effective to dismantle nuclear programs gradually while at the same time exercising active control (Kirillov, Morozov, and Pavlov 2004). Moreover, Russia, China, and South Korea offered energy aid, provided that the DPRK froze all its nuclear activities and allowed entry of international inspections in the third round of the Xix-Party Talks in June 2004.

There are, however, hot debates between Russia and the United States and South Korea regarding the DPRK's demand that it be allowed to keep a civilian nuclear program. The United States and South Korea dismissed the demand because it might make it easier for North Korea to resume an arms program (Kahn 2004). Although Russia affirmed its interest to eliminate North Korea's nuclear arms program, it maintained that that civilian nuclear research was a complicated affair because the DPRK was not liable to IAEA rules (Zyuzin and Morozov 2004).

It seemed at first that Russia's entry to the Proliferation Security Initiative and support for the Sea Island summit statement would lead to a closer tie with the United States. However, in the third round of the Talks, differences between Russia and the US policies became more 
apparent. For one, Russia strongly supports North Korea’s demand to keep a nuclear program for peaceful purposes, provided that it rejoins the NPT and allows IAEA inspections.

\section{Consensus-Building with Japan}

Ever since the inauguration of the Bush administration, hope for United States was largely in the hands of Japan, which had continuously expressed its support over the North Korean policy by Bush administration. Japan gave a high priority to the North Korean nuclear threat, especially after the Taepo Dong missile launch over Japanese islands in 1998. For Japanese, North Korean missile activities pose a direct threat for the country. Unlike South Korea, Japan urged the Bush administration not to drop the DPRK from its terrorism list. Japan suspected North Korea of providing sanctuary to members of the Japanese Red Army. Moreover, the admission by Kim Jong-II of kidnapping 13 Japanese raised new concerns for the Japanese government.

In the second round of the Talks, Japan and the United States were unyielding and demanded that North Korea abandon its nuclear weapons program in a complete, verifiable, and irreversible manner (Takeda 2004). Japanese media praised the result of the second round of the Six-Party Talks. They said that Japan was facing two tasks: to continue to stick to the principle of the de-nuclearlization of the Korean peninsula by joining hands with the United States and South Korea to pressure North Korea to eliminate its nuclear program totally; and to seize opportunity, realize the next round of governmental talks with DPRK as soon as possible so as to let families of the kidnapped Japanese return home (Participants Comment on Second Round Six-Party Talks 2004).

Just before the second round of the Talks, Japan’s House of Representatives approved a bill amending the Foreign Exchange and Foreign Trade Control Law, which was aimed at halting 
trade and blocking cash remittances to the DPRK. This was a unilateral act enabling the Japanese government to impose economic sanctions on any country considered a threat to Japan's security. The threat represented crucial political leverage for Japan against the DPRK in the context of the current nuclear crisis and abduction issue. Naturally, the DPRK criticized Japan for this one-sided action (Takeda 2004).

The sanction threat would force Pyongyang to stay in the Six-Party Talks. Japan is the DPRK's third-largest trading partner after China and South Korea. In addition, remittances from pro-Pyongyang Koreans and Japanese in Japan are a major source of income for North Korea. Therefore, only Japan, in addition to China, could have a serious economic impact on North Korea (Takeda 2004).

During the third round of the six-party talks, Japan noted common ground in the parties "understandings and proposals in the sense that focus is given to first steps towards nuclear dismantlement” (The Ministry of Foreign Affairs of Japan, General Evaluation 2004: parag 2).Japan identified an approach that, "while the DPRK aims for an agreement on freezing of its nuclear programs and compensatory measures, Japan, the United States and South Korea seek an agreement on a framework towards 'dismantlement' of nuclear programs” (The Ministry of Foreign Affairs of Japan, General Evaluation 2004: parag 3).

Japan also stated at the third round of the Six-Party Talks in June 2004 that if the proposed nuclear freezing by North Korea was defined as a first step towards dismantlement of its nuclear programs, it would be willing to join in energy assistance through the Talks based on the following conditions: (1) the scope of nuclear freeze would cover all nuclear programs, including the uranium enrichment program; (2) North Korea would declare all unclear programs; and (3) freezing would be adequately verified (The Ministry of Foreign Affairs of Japan, Japan's 
Position 2004: parag. 1).Additionally, the Japanese delegation indicated that economic cooperation with the DPRK could only be provided if its additional concerns about missile and abduction issues had been comprehensively resolved (The Ministry of Foreign Affairs of Japan, Japan’s Position 2004: parag. 3).

From a diplomatic perspective, Japan could serve a vital role in US implementation of its policy on North Korea. First, it has a large leverage over the DPRK. Second, Japan is equipped with an excellent intelligence reporting capacity. Third, the position taken by Japan was closest to that of the US. The Koizumi government has been very supportive of the Bush administration's North Korea policy from the very beginning (The Ministry of Foreign Affairs of Japan).

\section{The Kim Regime}

One of the systemic constraints that has continued to challenge the Bush administration is the firm stand of the Kim regime that the United States is employing hard policies and that the United States position in the nonproliferation regime is flawed, thus casting a doubt on the US intention of resolving the North Korean nuclear threat. On May 12, 2003, North Korea cited Bush’s 2001 termination of negotiations over North Korea’s missile programs, his inclusion of North Korea in his axis of evil, the administration's policy on preemption, and the US attack on Iraq as evidence that the US poses a threat to the DPRK. The United States, on the other hand, has argued for months that North Korea violated the 1992 Joint North-South Declaration of Denuclearization of the Korean Peninsula by pursuing a clandestine uranium-enrichment program.

In June 2003, the Bush Administration emphasized the effectiveness of putting pressure on North Korea by persuading other governments to bar shipments of items such as weapons 
components and illegal drugs, which are sources of hard currency for North Korea. John Bolton, Undersecretary of State for Arms Control and International Security condemned the idea of negotiating with Pyongyang. He declared that giving in to North Korean leader Kim Jong-il’s “extortionist demands” would only encourage the dictator and other "would-be tyrants” around the world (Kerr 2003: parag. 24). For National Security Adviser Condoleezza Rice, North Korea’s April 2003 proposal was nothing but “blackmail” (Kerr 2003: parag. 24). Nevertheless, an indication of US flexibility was shown through the agreement to solve the nuclear issue through synchronous and parallel implementation in the third Round of the Six-Party Talks in June 2004.

Prior to October 2003, the major conflicts between United States and North Korea concerned simultaneous actions and a non-aggression treaty. Although Washington promised that it could provide Pyongyang with written security assurances that have less formal congressional backing, North Korea insisted on a treaty to guarantee the reversal of United States' “hostile policy” North Korea had repeatedly cited Washington’s “hostile policy” as justification to its nuclear program. ${ }^{36}$ Currently, however, the non-aggression treaty is no longer a major issue in Washington-Pyongyang relations, with the latter showing willingness to accept a written guarantee of the Bush government.

The Bush administration, on its part, has continuously made clear that the US does not intend to attack North Korea. Several joint statements, including the Agreed Framework, explicitly state this policy. Pyongyang, nevertheless, argues that the US National Security Strategy_which explicitly mentions North Korea — and the 2002 Nuclear Posture Review

\footnotetext{
${ }^{36}$ North Korea expressed fear that the US might attack the country in the same way that US-led coalition forces attacked Iraq in March 2003. It also cited the US policy on preemptive action as described in the September 2002 National Security Strategy formulated by the Bush II administration.
} 
indicate that the administration is preparing to attack it (Kerr 2003). ${ }^{37}$

This dissertation predicts that the Bush administration will make major changes regarding its policy on North Korea towards the end of Bush’s second term. As discussed earlier, the generally strong support from the US domestic institutions and from the American public has only strengthened Bush’s current policy. However, outside pressure from major players such as South Korea, China, Japan and Russia, in addition to the political behavior of the Kim regime, will eventually change Bush’s policy from strictly multilateralism and stick strategy to bimultilateralism and carrot strategy. The international regime will maintain its minor role in the Bush administration.

The major drivers for the shift from the current multilateral approach to bi-multilateral approach have been China, which consistently puts pressures on the Bush administration to have a one-on-one talk with the DPRK, and the Kim regime which has been demanding a bilateral talk since the start of the administration. However, six-party talks have contributed to the most important development for the adoption of the bi-multilateral framework. The United States and North Korea held several bilateral talks in Beijing in the context of the six-party talks. In the fourth round of the multilateral talks, held on July 26, 2005 to August 6, 2005 in Beijing, individual bilateral talks, along with the primary meetings of the chief delegates, were continually held among all parties. In the most important one-on-one sessions, the United States and North Korea met at least ten times. Thus, already, bi-multilateral approach is being used by the Bush administration, instead of strictly a multilateral approach.

The results of the recently-concluded fourth round of the six-party talks produced a measure of cautious optimism among some participants and observers. This is brought about by

\footnotetext{
${ }^{37}$ There was once a leakage of the Bush administration's January 2002 classified Nuclear Posture Review and it lists Norht Korea as a country against which the US should be prepared to use nuclear weapons for (Kerr, 2003).
} 
a more productive atmosphere than at the previous rounds of talks, allowing participants to concentrate on searching for a comprehensive solution to the problem. Also, both Washington and Pyongyang are serious about working out a package deal which can resolve the North Korean nuclear problem peacefully. In this latest round, North Korea was confronted by a softened US approach. It seems that North Korea is responding positively to these proposals by offering to freeze its military nuclear program and to start negotiations on dismantling equipment related to this program in return for assistance in energy supplies, lifting of economic sanctions and security guarantees from the United States. In addition, other parties are encouraging the United States to assume more diplomatic approaches to prevent war in the region.

Thus, carrots instead of sticks are used to cajole Pyongyang to agree to the demand of the United States and other powers on dismantling North Korea's nuclear weapons program. Figure 6. Impact of Systemic Constraints on Bush’s Policy


The diagram above is an oversimplification of systemic constraints faced by the Bush administration in resolving the North Korean nuclear problem, and their impact on the implementation of Clinton’s policy. 


\section{Synthesis}

Critics describe the Bush administration’s policy towards North Korea as "bipolar.” For example, in his article, “Bush's Bipolar Disorder and the Looming Failure of Multilateral Talks With North Korea,” Peter Hayes, Executive Director of the Nautilus Institute, predicted that until America is indicates what it is willing to do for North Korea and when, and what Pyongyang must do in mutually dependent fashion, the multilateral effort will not achieve Bush's objective of resolving the nuclear crisis; indeed, what is lacking is political will on the part of the Bush administration (Hayes 2003).

Arguably out of indifference, Bush has adopted an aggressive stance towards North Korea, threatening economic and military sanctions for non-compliance, and has created an appearance of willingness to initiate military attacks to destroy North Korea’s nuclear capabilities. Despite denials from the administration that the United States has designs to attack North Korea, reports of possible attacks have increased apprehension for North Korea.

Moreover, Pyongyang's distrust of American intentions has been further exacerbated by the US attack of Iraq. Table 8 below outlines the likely shift of the Bush Administration's policy on North Korea.

Table 8. Possible Changes in Bush’s North Korean Nuclear Policy

\begin{tabular}{|c|c|c|}
\hline \multicolumn{1}{|c|}{ Variables } & Beginning & End \\
\hline Type of Negotiation & Multilateral & Bi-multilateral \\
\hline Sanctions/Rewards & Stick Approach & Carrot Approach \\
\hline Role of International Regime & Minor & Minor \\
\hline
\end{tabular}

Another example of inconsistency within the Bush Administration is evidenced by its reactions to South Korea’s Sunshine Policy. Despite initially turning a cold shoulder towards South Korea’s policy, the Bush Administration later issued statements supporting the policy. 
However, as Larry A. Niksch observed, the “administration’s response to the sunshine policy indicates a mixed reaction” (Niksch 2003: 12). That is, while it supports some components of the policy, such as building roads and railroads along demilitarized zone and reunification of divided Korean families, the administration has also expressed disagreement over other components, especially the issue of dropping North Korea from the US terrorist list. Even Kim Dae Jung, a strong proponent of the sunshine policy, expressed some doubts on the Bush administration's sincerity in supporting the sunshine policy. This inconsistency stems from the disagreements inside the administration regarding the proper North Korean approach, as well as from contending views of the North Korean political-economic processes. Hard-liners in the Bush administration doubt the possibility of North Korea relinquishing its nuclear capabilities in exchange for benefits, and, for them, the only option is force and pressure by building an international coalition.

Despite these inconsistencies, the Bush administration has continued in refusing to enter into bilateral negotiations with the North. Bush has insisted that his diplomatic approach toward the North Korean issue will be limited to the formation of a regional coalition involving the DPRK’s neighbors. He has refused to back down to North Korea’s demands, and has insisted that there will be no bilateral engagement until Pyongyang relinquishes its nuclear program. This approach, however, has received criticism from other countries, most notably China, who insisted that the United States engage North Korea directly, in a bilateral agreement. Despite pressure from China, Russia and other countries as well as some US officials, Bush has held firm on his decision to stick to multilateral efforts instead of engaging North Korea in bilateral negotiations. Peter M. Beck argues that the inability to engage North Korea in meaningful negotiations can be viewed as failure on the part of the Bush Administration (Beck 2004). He 
reiterated China's worries that such malign neglect by the Bush administration would only lead to war. The United States is willing to talk not negotiate with North Korea, though only in the context of a multilateral forum. To be sure, President Bush has made it known that he also rejects the notion of bilateral talks within a multilateral forum (Kristoff 2003).

The inconsistency within the Bush administration can be regarded as one of the factors in the failure of the United States to resolve the North Korean issue. The Bush Administration's inability to resolve the internal divide between hard liners and pragmatists within the administration has been creating an atmosphere of contradiction in the administration. Moreover, the United States participation in the Six-Party Talks by the Bush Administration has been strung with a division within the government, particularly that of the inconsistency in the pronouncements of the administration.

The administration's erratic swings, from limited diplomatic engagement one day to “personal” statements by John Bolton prefiguring the collapse of North Korea the next, and then back to engagement the day after, reveals a real lack of strategic coherence on the Bush administration’s part. However, recent trends favor engagement—partly because the hard-liners have been forced to pull in their horns by the deteriorating situation in Iraq. Nonetheless, it is evident that the Bush administration is not yet ready to accept any answer from North Korea.

Despite achieving relative success in making other countries put pressure on the DPRK, the reluctance of Russia, China, and South Korea to cut off trade with North Korea completely has pushed the United States to consider imposing more tailored sanctions that will focus on banned activities on North Korea. Although Japan has been compliant in supporting the Bush administration policy, Washington has found it very difficult to convince either China or Russia to support its policy on North Korea, as neither of them support sanctions or a hawkish policy 
from Washington, despite understanding the seriousness of the threat that a nuclear-armed DPRK poses to regional stability.

Russia abstained on the IAEA vote to send the North Korean nuclear issue to the UN Security Council in 2003. China rebuked North Korea, by voting to send the issue to the Security Council, though it has not gone beyond that. South Korea, China, and Russia, and even Australia have all publicly urged the US to negotiate bilaterally with North Korea, and both Beijing and Seoul did so publicly when Powell swung through East Asia to build support for US policy of multilateral negotiations. Russia, China, Japan, and South Korea have all tried to mediate between North Korea and the US and even Fidel Castro has offered to mediate, though the US rejected all these offers until 2004.

China has been urging North Korea for almost a decade to take reforms similar to those China itself has taken. It has even been rumored that Kim Jong Il would not take calls from the Chinese leadership if he thought they were going to ask him to do something he doesn't want to do (Sorensen 2003). Chinese influence over North Korea, in fact, is much more limited than most people often think (Sorensen 2003). Because of this limited influence, the Chinese are very wary of taking responsibility for North Korean behavior. And South Korea, as mentioned above, because of their fears of a North Korean collapse, does not want to put any more economic pressure on the DPRK. In any case, the expectation that China will enforce the US foreign policy displays willful ignorance of the contribution of US foreign policy to the current impasse, as well as ignorance of many of China’s foreign policy concerns. For North Korea, the Bush administration's decision not negotiate with them resulted to the breakdown of the Agreed Framework and the subsequent revival of their nuclear reactors. The fact of the matter, however, is that North Korea's violation of existing agreements with the United States and others by 
carrying out a clandestine uranium-based nuclear weapons program led to the breakdown of the Agreed Framework. The Chinese have no particular responsibility for that breakdown, but because they are unhappy with the North Korean actions, they have made efforts to mediate and to bring the US and the North Koreans together.

The Bush policy towards North Korea has been antagonistic from the start. The administration reversed the diplomatic advancements to reestablish normalized relations with Pyongyang that had been made during the Clinton Administration and, in particular, refused to affirm the October 10, 2000, pledge from President Clinton, stipulating that the US and North Korea held no hostile intent towards each other. The US policy towards North Korea has become further clouded with the administration's doctrine of preemption. The National Security Strategy specifically mentions North Korea as “the world's principal purveyor of ballistic missiles” and states: "We [the United States] cannot let our enemies strike first.” The United States has discussed the North Korean situation with regional allies such as Japan and South Korea, and other interested regional players, such as Russia and China (Sigal 2002). Indeed, none of North Korea’s regional neighbors has actually committed to imposing pressure on North Korea in the form of sanctions or trade restrictions, as the United States has advocated, and China currently supplies 70\% of North Korea’s imported fuel oil, and has refused United States pressures to cease fuel exports to North Korea. While the United States seemingly continues to hope that the DPRK regime will fall if fuel shipments cease, this result does not seem to be in line with China’s wishes and policy direction. Rather, China’s apparent concern is with a possible North Korean refugee crisis if conditions in North Korea continue to worsen, not to mention the political instability of Northeast Asia that would follow any political disintegration. Other neighboring countries, including South Korea, share these concerns (Kessler 2003). Japan and 
South Korea have resisted development of their own nuclear weapons program, claiming that retaliatory action by the United States would serve as enough of a deterrent. However, that policy has recently been seen to be shifting. Japan, like South Korea, has talked about developing a nuclear weapons program in response to Pyongyang's nuclear development and military posturing (Nishihara 2003). 


\section{CHAPTER V: STRUCTURED FOCUSED COMPARISON WITH CONCLUSION}

So far, this study has illustrated the complexities of the North Korean nuclear crisis, and analyzed how the Clinton and Bush administrations have attempted and are attempting to resolve this global threat. Moreover, the previous chapters have discussed the domestic and systemic factors that Clinton and Bush have faced in their quest to resolve the North Korean nuclear problem, and how these factors have influenced the course of their policies. Using a structured focused comparison, this chapter attempts to show that the policies under both Clinton and Bush, while differing initially, will eventually follow a similar policy path, due to the similar features of domestic and systemic constraints that had/have impacted the two administrations’ policy.

\section{Comparing Initial U.S. Administration Policies}

Since the Korean War, North Korea has been a headache for the United States. At the beginning of their terms, Clinton and Bush tried to ignore the brewing problems in North Korea. ${ }^{38}$ However, due to the alarming threat North Korea has posed, especially when it became known that it had been cultivating its own nuclear program, the two administrations were forced to engage the country early on in their respective administrations, a task that would help define their early reputations on policy making (Reiss 2004). However, their circumstances for being drawn into the affairs of North Korea were remarkably different. That is, while Clinton was driven by the threat of the potential nuclear capabilities of North Korea, Bush was, and is, using the threat of terrorism as a basis for action. As such, it is also the case that each of their approaches to the North Korean situation was also different. Despite these differences, however, many similarities have also been apparent between how Clinton and Bush initially dealt with North Korea (Reiss 2004).

\footnotetext{
${ }^{38}$ During his first presidential campaign, Clinton never made any mention of North Korea. The case was the same with Bush.
} 
Through the years, North Korea has developed and built additional nuclear facilities that are now capable of constructing nuclear weapons. The discovery of the secret nuclear facility, discrepancies in the reported nuclear materials and nuclear wastes, as well as its subsequent refusal to allow IAEA inspections, aroused fear and suspicion that North Korea was trying to develop nuclear weapons. The danger of having a nuclear-armed North Korea, and the possibility that North Korea would export weapons and raw materials for making nuclear bombs to other countries forced Clinton to stop ignoring North Korea. Bush, on the other hand, put pressure on North Korea as part of his war on terrorism. Indeed, the cost of the September 11, 2001 attacks for the US, both financially and emotionally, was great. Suddenly the country did not feel safe anymore. Both the administration and the public felt an urgent need to act against terrorists to replace US' sense of security. As one of the countries with a hostile record, North Korea was viewed by the Bush administration as posing an international threat, and thus deemed appropriate to be included in Bush's formulation. Not surprisingly, the DPRK took offense to this, and admitted that it had an active nuclear program (Sanger 2002), thus prompting the Bush administration to halt oil shipments in December. However, South Korea and Japan pressured the Bush administration to allow the November shipment, which was already en-route, to proceed to the DPRK (Dao 2002).

In summary, the Bush administration initially deviated from the containment and engagement policy under Clinton, and instead of continuing with a liberal internationalist approach, employed the conservative internationalist approach. Moreover, Bush demanded that Pyongyang destroy its nuclear weapons before allowing diplomatic negotiations; Bush used a multilateral approach, used economic sanctions and military sanctions instead of carrot strategy utilized by Clinton; Bush ended Clinton’s Agreed Framework and started a six-party talk with 
China, South Korea, Japan, Russia, and North Korea.

Table 9 below outlines the initial policies of the Clinton and Bush administrations in attempting to resolve the North Korean nuclear crisis.

$\underline{\text { Table 9. Initial Policies of the Clinton and Bush Administrations }}$

\begin{tabular}{|c|c|c|}
\hline Initial Policy & Clinton Administration & Bush Administration \\
\hline $\begin{array}{c}\text { Bilateralism and } \\
\text { Multilateralism }\end{array}$ & Bilateral diplomacy & Multilateral diplomacy \\
\hline $\begin{array}{c}\text { Carrot and Stick } \\
\text { Strategy }\end{array}$ & $\begin{array}{r}\text { Economic rewards and stoppage } \\
\text { of military training exercises }\end{array}$ & $\begin{array}{r}\text { Economic sanctions and } \\
\text { intensification of military activities }\end{array}$ \\
\hline $\begin{array}{c}\text { Inclusion and } \\
\text { Exclusion of the } \\
\text { International Regime }\end{array}$ & Major role of the international regime & $\begin{array}{c}\text { Minor role of the international } \\
\text { regime }\end{array}$ \\
\hline
\end{tabular}

\section{Multilateralism versus Bilateralism}

The events that transpired between the United States and North Korea early in Clinton and Bush administrations are rich in Foreign Policy decision-making (Reiss 2004). Clinton decided to use diplomacy in addressing North Korea’s nuclear proliferation, whereas Bush refused to maintain diplomatic relations. Clinton preferred bilateral negotiations while Bush adopted a more multilateral brand. After realizing that sanctions would not work, Clinton began engaging North Korea in high-level talks, which eventually resulted in the framing of the Agreed Framework. According to Glenn P. Hastedt, bilateral diplomacy can be defined as "[a] form of diplomacy in which two states interact directly with one another" (Hastedt 2003: 291).

From the above definition, it becomes apparent that much of the dealings with the DPRK during the Clinton administration were of a bilateral-diplomatic form. The Clinton administration successfully negotiated a direct diplomatic deal with the DPRK, whereby Pyongyang confirmed its willingness to freeze its nuclear weapons program, and agreed to resume high-level talks with the US (with the exclusion of South Korea, Japan, China and Russia). The product of this bilateral negotiation was the Agreed Framework, which called for the freezing of North Korea 
nuclear activities, and the eventual elimination of its nuclear facilities. Clinton's bilateralism was comprised of high-level talks that discussed the issues and concerns between the two countries, ranging from nuclear program issues, economics, politics and conventional military use (Juster 2000; Mearsheimer 1990: Pilat 1994; Sigal 2000). Observers suggest that through this bilateral approach, the US was able to moderate rogue states’ behavior, and, as such, Clinton's bilateral strategy was characterized as aiming to contain North Korean aggressions with stability.

While the Clinton administration advocated bilateral diplomacy, Bush administration has employed multilateralism. Bush went out of his way to make it known that he prefers to have multilateral talks (Kristensen 2002). The Bush administration made it clear from the start that the United States wanted to work with Japan and South Korea, and called for a Unified Front (Dao 2002). In the words of Powell, "It is a matter for China, it's a matter for South Korea, it's a matter for Japan, it's a matter for Russia, it's a matter for the United Nations, the IAEA, and it is a matter for the United States” (Office of International Information Programs, US Department of State. February 24, 2003). In other words, the Bush Administration recognizes that the problem is not only between the United and North Korea; rather it is a global problem. South Korea and Japan, as well as China and Russia have a particular interest in dealing with South Korea because they are so close to the DPRK. South Korea and Japan have been adamant about maintaining open lines of communications with the DPRK, contending that "engagement is the best way to change its behavior" (Dao 2002: 1).

North Korea’s actions showed its preference for bilateral negotiations with United States. After withdrawing from the NPT and rejecting IAEA inspectors, the DPRK resumed the operation of its nuclear facilities, frozen under the Agreed Framework. It further announced that it had almost finished reprocessing enough plutonium-grade materials that could create a nuclear 
bomb and threatened exporting these to other countries. These actions could be an attempt by North Korea to force the US to engage it in bilateral negotiations. However, Bush insisted on his more isolationist policy by refusing to send negotiators in the peninsula. Although Bush agreed to stage a talk with North Korea, he wanted Japan, South Korea, China and Russia to be included in the forum. Other countries viewed Bush's refusal to engage in a bilateral negotiation as more of a policy of neglect, and they feared that this would lead to miscommunication problems and potentially spark all-out war.

When North Korea withdrew from the NPT, the Bush administration proposed multilateral negotiations to South Korea, China, Japan and Russia, in an attempt to come up with a diplomatic settlement of the North Korean nuclear problem. Initially, the DPRK believed that the crisis was purely a bilateral matter between the US and the DPRK. In the end, however, North Korea eventually agreed to three-party talks with China and the US. The outcome of the trilateral talks was restricted by the Bush administration's failure to get South Korea to attend the talks.

The framework established by the trilateral talks was eventually liNorth Koreaed with the Six-Party Talks involving the United States, North Korea, South Korea, China, Japan and Russia, as the Bush administration insisted that the North Korean nuclear threat was a global issue best resolved through a multilateral negotiation (Daalder and Lindsay 2003). During the first round of the talks, the DPRK agreed to eliminate its nuclear activities, provided that the United States be willing to sign a bilateral non-aggression treaty and meet various other conditions, including the provision of substantial amounts of aid and the normalization of diplomatic relations.

Initially, the Bush Administration was unyielding on its position, insisting on a multilateral resolution to the issue, and refusing to provide incentives for North Korea to abide 
by its previous international obligations. Current developments, however, show that the United States is now willing to provide material "incentives" to North Korea in the event the DPRK agrees to dismantle its nuclear weapons program. A package deal is in the making starting from the third round of the six-party talks in June 2004. Some significant progress was also made at the fourth round of the six-party talks. The United States and North Korea held ten bilateral talks throughout the fourth round of the six-party talks. Thus the Bush Administration is now using bimultilateral approach in dealing with the North Korean nuclear problem.

\section{Rewards versus Sanctions}

The Clinton administration's policy toward the DPRK had been grounded on the engagement policy. As such, the Clinton administration worked on kittens economic rewards for the DPRK, and bargained bilaterally through diplomatic means. The bilateral negotiations resulting to the Agreed Framework promised economic support and favorable trade provisions for the DPRK provided that North Korea shall freeze its production of nuclear weapons. On the other hand, while initially announcing support of the Clinton administration’s engagement policy, the Bush administration has indicated that it wants a hard line policy. This means that the DPRK's compliance with the Bush administration's requirements will yield rewards, such as the normalization of relations and a larger aid package. Indeed, the banner that the Bush administration used in its policy on North Korea is "bigger carrot, bigger stick.”

After abandoning the policy of indifference towards North Korea, the Clinton and Bush administrations chose to use sticks instead of carrots. Clinton employed military coercion when the US started military training exercises in South Korea, labeled as Team Spirit. These military training exercises were meant to intimidate the DPRK to force it to comply with US requirements. In addition, the Clinton administration threatened to employ economic and trade 
sanctions against North Korea. However, the North Korean response of threatening to withdraw from the NPT made Clinton realize that a coercive approach would not work. This threat showed the Clinton administration that a show of aggression might only provoke the DPRK to do something drastic and erratic, and hence the military threat was not an effective policy option (Henriksen 1996: 48), thus forcing the US to turn to different approaches aimed at rewarding North Korea. Moreover, after negotiating with the US, South Korea, and Japan, the DPRK agreed to stay in the NPT. The US feared that the DPRK would carry out desperate actions and worsen the nuclear threat if they continue military training exercises in South Korea. With this, Clinton provided an economic reward to North Korea, and did not impose any trade sanctions or military actions against the country.

Clinton began dangling carrots to tempt North Korea from withdrawing from the NPT and to comply with US requirements. North Korea's agreement to remain in the treaty was rewarded by Clinton's apparent willingness to negotiate the removal of trade sanctions as a policy approach. Despite the ongoing tension between USA and North Korea, largely due to Kim II Sung barring IAEA inspectors from North Korea’s nuclear reactors, the two countries were able to lay down an agreement that became embodied in the Agreed Framework of 1994. Furthermore, the US assisted in giving and receiving economic and energy aid, such as food aid for North Korea. This approach of rewarding good behavior was again employed when the Clinton administration persuaded the DPRK to enter the Agreed Framework treaty. Here, the US built new reactors and shipped oil to the DPRK in return for Pyongyang's decision to turn off their old nuclear reactors. However, analysts debated if it was really a reward or just to appease the DPRK (Reiss 2004). The reactors that the US agreed to help build were to compensate the DPRK for closing their older reactors, and the oil would not be shipped until the reactors were up 
and working. In short, this would appear to be more of compensation rather than reward (Henriksen 1996).

The Bush administration, in addition to some scholars and critics, criticized Clinton’s policy as a show of weakness, and argued that Clinton was giving away carrots without getting anything in return. They believed that North Korea was just using its nuclear capabilities as a bargaining chip against US, in order to achieve stability and economic incentives. Bush, on the other hand, had chosen to lay a firmer hand to North Korea, and adopted a strategy that took a much different approach than Clinton had. Clearly, the Bush administration has taken the stick side of the carrot-stick spectrum. Evidence includes the characterization of Kim Jong Il as a dictator, US' increased Cold War sensibility, and a strong support for missile defense. Moreover, the Bush administration has made missile defense its strategic priority. However, Bush’s stick strategy has been opposed by South Korea, China and Russia, who are concerned that increased military activities might endanger diplomatic engagement with the DPRK.

From the beginning of his policy, Bush chose to impose economic and trade sanctions. The first punishment came after the DPRK admitted that it had an active nuclear program, in violation of the agreed framework, Bush decided to halt oil shipments to the DPRK. He also expressed the desire to stop the construction of water-light reactors. Bush policy was to bully North Korea to back down and yield to the US requirements. These sanctions would surely hurt the already weak economy of the DPRK. North Korea was largely depending on the oil shipments from the US for its energy needs, and the building of the reactors was giving jobs to many North Koreans. A US decision to cut funding for the reactor and to cut off the oil shipments, could be disastrous for the DPRK. 
Initially, the Bush Administration's use of economic sanctions was deemed as an unsuccessful attempt to change North Korea's political behavior. North Korea was not likely to be adversely affected by any economic sanctions because it had alternative trading partners, possesses a command economy, was not dependent on foreign trade, and had become accustomed to economic isolation over many generations (S. Kim 1996: 69-80). However, major changes have happened since the Kim Jong Il Government’s July 1, 2002 announcement of the countries economic reform measures. This suggests that the DPRK may yield to economic sanctions imposed upon by the United Nations, the United States, and its allies.

International pressure, coupled with the lack of a productive response from North Korea, has created a softening in the Bush administration's position towards North Korea. However, this softening has not extended to an all-out dangling of economic rewards, as had happened under the Clinton administration. Rather, Bush has expressed the willingness to "consider" giving North Korea economic, military and political incentives, provided that North Korea takes the first action and conduct an irreversible and verifiable dismantling of its nuclear program. North Korea, however, has its own demands — that US resume oil shipments, and enter into a bilateral negotiation with them. Only after their demand is fulfilled will they be willing to freeze, though not dismantle, its nuclear program.

Yet, unlike Clinton’s Agreed Framework, the outcome of the first round of the Six-Party Talks promised little economic reward for the DPRK. Moreover, the Bush administration was vague on what rewards it might bestow upon North Korea if it agreed to dismantle its nuclear weapons program in a verifiable and irreversible manner. In the same vein, while the Clinton administration's Agreed Framework yielded concrete outcomes, while the Six-Party Talks failed as the participating nations were unable to come up with a joint statement or to make significant 
breakthroughs.

Though Clinton could brag that his approach of using carrots instead of sticks were able to make North Korea comply with the American nonproliferation policy, by freezing its North Korean program, the Agreed Framework and the use of carrots were not a long-term solution to the North Korean nuclear proliferation problem. What Clinton's policy really did was simply suspend the problem in North Korea, until something eventually caused it to resurface such as the September $11^{\text {th }}$ terrorist attacks. The two countries once again returned to the state where no agreements would be made and tensions were escalating. In addition, North Korea's tendency to utilize brinkmanship tactics with its nuclear capabilities as a bargaining chip certainly does not appear to be helpful toward the achievement of US goals. Indeed, the US just appeared to be rewarding North Korea for nothing. As North Korea’s nuclear program remained a looming threat for the US for which reason the US could not stop giving economic incentives, the condition began to resemble blackmail, in which the US is the one in a disadvantaged position.

In summary, there are clear differences between the Clinton and Bush administrations policies towards the DPRK. Clinton supported carrots, enticing North Korea to comply with the US by offering economic rewards. On the other hand, the Bush administration, is attempting to bully the DPRK into complying with economic threats. It is difficult, however, to examine the comparative effectiveness of the two administrations' respective policies, as we do not exactly know how Bush's policy will fare at the end of his second term. What we can critique though is Clinton's policy. According to some observers, Clinton tended to provide economic rewards to the DPRK for breaking agreements. For instance, Henriksen (1996) has observed that, "For simply returning to the status quo, the North Koreans gained concessions" (31), thus potentially giving the DPRK the idea that it could get what it wanted by breaking treaties and agreements. 
Moreover, some analysts viewed Clinton's policy as furthering the North Korean nuclear crisis: the building of a new light water nuclear reactor, under the Agreed Framework, could actually produce just as much plutonium as the older reactors do (Henriksen 1999). With these apparent flaws in the Clinton administration’s policy, it becomes easier to understand why the Bush administration would want to break away from the Agreed Framework (Reiss 2004).

Overall, the Clinton administration's tendency to use economic rewards, and the Bush administration's use of economic and trade sanctions, have generated debates among scholars. That is, Conservatives tend to favor the stick strategy, whereas more liberal realists contend that carrot should be the dominant approach. In the same line, some observers advocate utilizing both carrots and sticks, especially with regard to resolving the North Korean nuclear problem. Indeed, it is argued that while carrots without sticks would end up as an appeasement policy, sticks without carrots would result into unnecessary loss of lives. There are some scholars who surmised that the use of economic rewards and sanctions are actually complimentary, and not contradictory (O’Hanlon and Mochizuki 2003), and the right combination of such strategies would be more effective than any other strategies pursued by the Bush administration (Choi 2003) as well as with previous administrations.

According to this line of thinking, the US and its allies should not give Pyongyang substantial aid and other benefits simply to appease Kim Jong-Il. But if the Kim regime agreed to freeze and eventually eliminate all its nuclear programs, transform the broader security situation on the peninsula, reform its economy, and even begin to change its own society, the US and its allies can and should be generous in providing economic aids. This does not mean weakness, but a promising way to truly resolve the North Korean nuclear crisis. However, if the DPRK remains tough and does not verifiably cooperate with this effort, the US and its partners could then get 
tougher and employ punishment strategies.

\section{Containment and Engagement}

Both administrations initially attempted to isolate North Korea through an international effort to impose sanctions. However, both administrations were, at some point, forced to directly engage North Korea at very different levels. Clinton underwent a higher level of engagement by directly engaging North Korea in bilateral negotiations, and acquiring and providing North Korea with economic and energy aid. Bush, on the other hand, maintained considerable distance from North Korea. Moreover, it limited its engagement with North Korea to multilateral talks and refused direct negotiations by not sending negotiators to the country.

The main similarity in both administrations has been the presence of divergent policy preferences among other actors. While both administrations initially relied on an isolationist, aggressive and unilateral policy, oppositions from other countries, such as China and Russia, forced them to temper their approach toward North Korea. Moreover, debates within the administration complicated policy-making. That is, with the Bush administration, hard-liners were constantly in debate with the less aggressive faction, and both of them had their own idea of which policy would best address the North Korean problem. The case is not different with Clinton's. These policy debates affected the two administrations policy positions and created for them an appearance of inconsistency.

Although the Clinton and the Bush policies towards North Korea are remarkably different, there are some similarities, most notably with avoidance. Both administrations attempted to employ isolationism, but both were ultimately forced to engage the DPRK. The Clinton and Bush administrations then decided to give the appearance of action, and then operated on different background to push the North Korean nuclear problem aside. While 
Clinton used the cover of negotiations and agreements, Bush used the war in Iraq to shift attention away from the ongoing problem in the DPRK.

Analysts also observe that the Bush administration has been applying a policy more characteristic of neglect than engagement (Reiss 2004). Much of the events in North Korea have been overshadowed by other world events, such as the war on Iraq. While Iraq has gotten the full burden of the war on terrorism noting especially the consistent talk of war and regime change, the DPRK has only received strong words without action. This neglect to the North Korean problem is manifested when North Korean officials wanted to set up negotiations over their nuclear weapons program. But the Bush administration, concentrating on the Iraqi problem, refused to meet (Shenon 2002). This further complicates the problem and may result in serious miscommunication, as lines of communications between two states in disagreement become closed.

\section{The International Regime: NPT and IAEA}

In the beginning, both the Clinton and the Bush administrations were supportive of the international nonproliferation regime composed of treaties, international organizations, multilateral and bilateral agreements, and unilateral actions aimed at preventing further proliferation. The NPT, IAEA and other actors, such as the international export control regimes, played a very crucial role in the detection of nuclear weapons and in containing Pyongyang's nuclear program at the outset of the Clinton administration. As the inclusion of the international regime has been a part of their strategy to gain the support of the international community, the Clinton administration closely coordinated with the IAEA in its military intelligence, and used the legitimacy of the NPT to muster cooperation from countries and demand that North Korea freeze its nuclear programs. Similarly, the international regime presents one of the more 
significant sources of measurement in enforcing the initial policies of the Bush administration, although its role during the time had been diminished, when compared to its major role at the start of the Clinton administration.

In both the Clinton and Bush administrations, however, the international regime has failed to implement actions in accordance with the US requirements. As we know, during the Clinton administration the DPRK threatened to withdraw from the NPT, and, worse, no longer allowed the IAEA to inspect its nuclear facilities. Moreover, in the following administration, Bush was dismayed by the eventual withdrawal of the DPRK from the NPT. Thus, the two administrations, later in their respective administrations, did not rely heavily on the international regime, but rather started developing their own strategies and approaches in dealing with the North Korean nuclear crisis.

Initially, the NPT had proved to be successful in mitigating the nuclear regime, though it failed to curtail the North Korean nuclear threat as the DPRK violated its provisions particularly when it removed the monitoring equipment the IAEA installed and expelled the inspectors, and announced it would resume its nuclear activities. The Clinton administration based its decision to abandon the international regime on the view that without the intelligence that would be provided by the IAEA and the NPT, the US would no longer benefit from the international regime. It should also be noted that the crime-and-punishment approach by the IAEA did not suit the policy of engagement by the US. Moreover, the relationship between the IAEA and North Korea during the first few months of the Clinton administration was deteriorating. Thus, it can be assumed that the Clinton administration proceeded with the bilateral talks with the exclusion of the NPT and the IAEA. 
As for the Bush administration, the international regime has taken only a minor role in its overall goal towards the DPRK. This is, in part, because of the perception that the NPT has been under assault by North Korea. Moreover, the Bush administration deems it difficult to come up with an agreement with other member-states in the NPT. In an NPT PrepCom meeting, the UK, the US and Russia were unable to come up with an agreement on how to handle North Korea's status upon its withdrawal date. A division between the state-parties themselves occurred as they debated on whether to acknowledge North Korea's withdrawal, or to overlook it.

\section{Table 10. Comparing Clinton’s and Bush’s Policy Towards North Korea}

\begin{tabular}{|c|c|c|}
\hline Strategy & Clinton Administration & Bush Administration \\
\hline $\begin{array}{l}\text { Bilateralism and } \\
\text { Multilateralism }\end{array}$ & 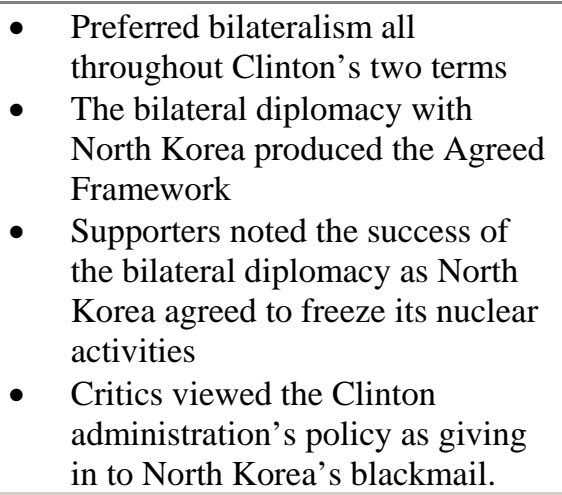 & 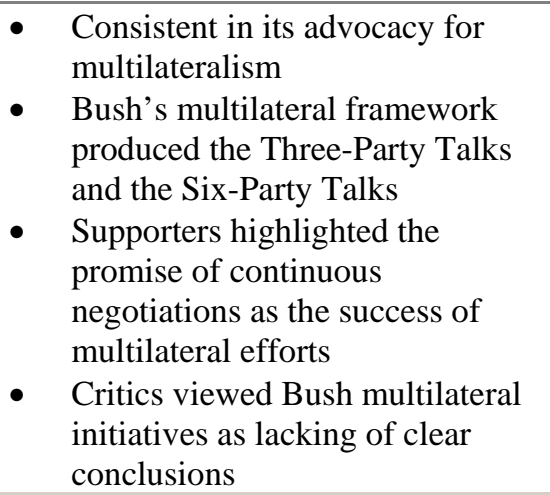 \\
\hline $\begin{array}{c}\text { Carrot and Stick } \\
\text { Strategies }\end{array}$ & 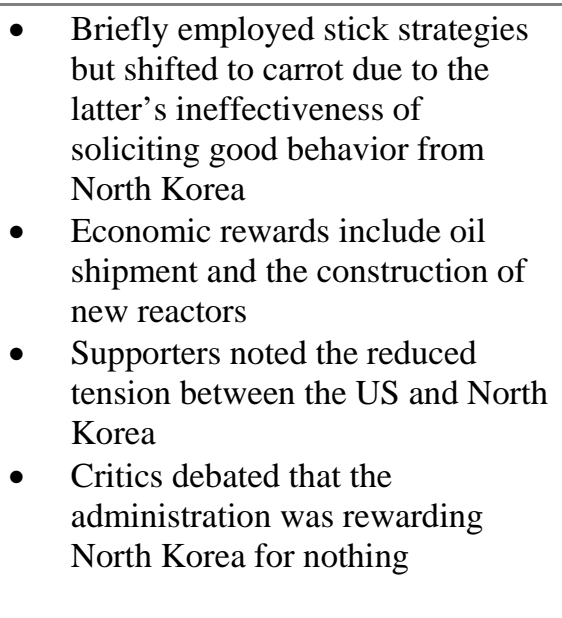 & 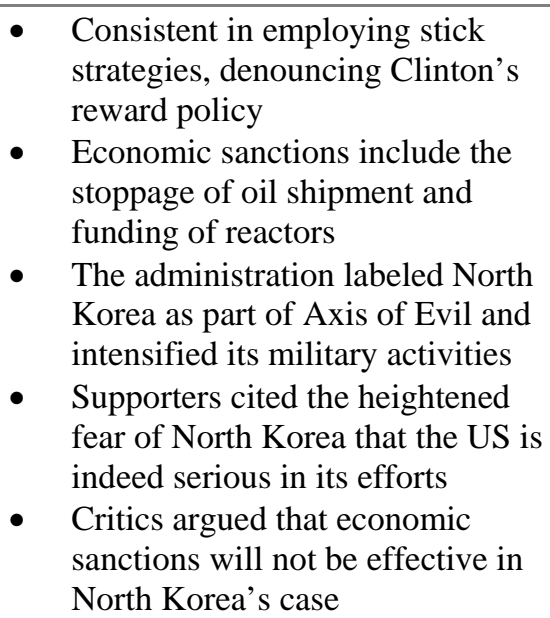 \\
\hline
\end{tabular}




\begin{tabular}{|c||l|l|l|}
\hline $\begin{array}{l}\text { Inclusion and } \\
\text { Exclusion of the } \\
\text { International } \\
\text { Regime }\end{array}$ & $\begin{array}{l}\text { At the outset, the administration } \\
\text { considered the major role of the } \\
\text { international regime } \\
\text { The administration abandoned the } \\
\text { NPT and IAEA as they failed the } \\
\text { US' expectations }\end{array}$ & $\begin{array}{l}\text { The Bush administration } \\
\text { considered the international } \\
\text { regime as having a minor role in } \\
\text { its policy towards North Korea } \\
\text { The administration does not rely } \\
\text { on the international regime as it is } \\
\text { difficult to build consensus with } \\
\text { other countries within he NPT }\end{array}$ \\
\hline
\end{tabular}

Table 10 above summarizes the similarities and differences between the Clinton and Bush administrations in terms of bilateralism and multilateralism, carrot and stick strategy, and inclusion and exclusion of the international regime.

\section{Constraints on U.S. Policies towards North Korea}

\section{The Role of Domestic Constraints}

The issue of how to best deal with North Korea's nuclear program has been a subject of numerous policy experiments (Wit 2001). US policies have yielded mixed results and the view of the vast majority lie somewhere in between (Wit 2001). With any multilateral enterprise, members' interests overlap but are not necessarily identical, and they often diverge in important ways, whether due to shaky parliamentary coalitions, domestic public opinion, financial constraints, or bilateral pressures (National Intelligence Council Conference Report, 2001). With regard to Clinton's and Bush’s approaches, their continuous policy and strategy shifts had largely been a product of the domestic constraints each had encountered from the US Congress, American culture and public opinion and bureaucratic politics (Amini 2002; Axelrod and Keohane 1985: 225-254; Behrens 2000; Okazaki 2001). Indeed, it was only after former Secretary of Defense William J. Perry became North Korea’s Policy Coordinator, in November 1998, that the Clinton administration was able to overcome what one critic termed its policy of strategic incoherence towards the North (National Intelligence Council Conference Report 2003). Moreover, it was only after the September 11 terrorist attacks in New York and 
Washington that the Bush administration got nods of favor from the congress, public opinion, and the bureaucracy.

The constraints and influences on options to resolve the North Korean crisis are diverse, and are firmly based on both the domestic politics in the US and the intentions of the North Korean regime. Domestically, legislators in the US-during both the Clinton and Bush administrations_-were at odds with one another on whether the North Korean nuclear program should be used for deterrence, or for the mere accumulation of power (Gross 2001). North Korea's intentions could be aimed at: (1) achieving nuclear deterrence to reduce the economic burden of maintaining a credible conventional military force; (2) achieving nuclear deterrence to narrow the increasingly advanced technology gap between US and DPRK conventional forces; (3) achieving credibility as an equal dialogue partner in negotiations for economic concessions, or; (4) seeking regime security by achieving economic concessions and maintaining a minimal level of nuclear deterrence (Rowen 2003). Not surprisingly, this haziness has led to policy formulation problems (Gross 2001). Since the Clinton and Bush administration have both been unclear on the real intentions of North Korea, the policies that were formulated were also uncertain (Litwak 2000). Clinton confronted North Korea in 1993 while Bush, in 2001.

The US Congress has been one of the foremost drivers in the Clinton's and Bush’s policies on the DPRK. In the case of the former, that administration consistently found difficulty in gaining Congressional support, while the Bush administration has been enjoying its general support. Aside from the legislation made by the Congress that significantly limited the Clinton administration's power to create a policy approach and strategy to resolve the DPRK problem, another key issue for Congress was the implementation of the agreement and the extent of the US contribution. While some senators and representatives opposed using US funds, most were 
not prepared to block implementation of the agreement. (See CRS Issue Brief 91141 and CRS Report 95853). The conflict between the Clinton administration and the US Congress regarding the North Korean policy resulted in the critiquing of the administration's management of American foreign policy (Dewar 1994: A1). In large part, this is due to the fact that the Clinton administration worked with a different, more independent, centralized, partisan and homogenous Congress, thus leading to a constant struggle. The difficulty of gaining Congressional support pushed Clinton to adopt a strategy of "going public". That is, the President approached the public to lobby sufficient support in order to pressure Congress to support his programs. However, the Clinton administration never seemed to win its way with Congress. Even during those circumstances when it was able to get Congressional support, Clinton had to exert considerable effort.

Under the Clinton administration, the Congress was noted for its apparent isolationism. Despite this, many scholars believed that the Congress did not completely reject internationalism, but rather they rejected Clinton's liberal, globalist brand of internationalism. Another angle regarding congressional constraints in the Clinton administration involved parochial, selfish political interests. Furthermore, the Clinton administration had to face a Congress dominated by Republicans who constantly challenged the administration's policy on North Korea.

As such, the implementation of the deal between the Clinton administration and North Korea was constrained by the US Congress. Together with Japan, the US had secured an agreement with North Korea, wherein the North would allow UN inspectors and cameras into the Yongbyon complex and would cease work on a nuclear plant that could make weapons-grade nuclear material, on the condition that the US and Japan would provide Pyongyang with food aid 
and oil to run its power plants, and that they would help it construct two commercial-grade nuclear power plants to generate electricity (Tomchick 2003). Clinton had a hard time selling this deal, and Congress approved the fuel oil but refused the two commercial nuclear plants. It is possible that Clinton already knew that he would not be able to gain the votes of the majority in the Congress, and that he may have agreed to commit with North Korea just for the sake of convenience (Tomchick 2003). Yet getting the North to the negotiating table was not sufficient to satisfy the critics of the Clinton administration, especially those in Congress. In addition, "bribing” the North to attend meetings with food aid sent the wrong signal to North Korea - that once the North merely showed up, aid would flow and its primary policy objective was achieved.

In contrast with the Clinton administration, the Bush administration has had only minor conflicts with Congress. The domestic challenges that the Clinton administration was confronted with almost vanished during the Bush administration (Cossa 2001; Reiss 2004). The Congress supported the Bush administration's choice of strategies in different foreign policy issues, and allowed Bush to wage two wars on terrorism, one of them being a preemptive strike against Iraq (Bock 2002; Newsmax.com Wires 2002), and supported the decision to withdraw from the 1972 Anti-Ballistic Missile Treaty (ABM). Unlike Clinton, Bush can carry the Congress with him (Power 2003), has had broad Congressional support that has allowed it to reach a series of agreements with Pyongyang on security and economic issues - something that eluded the Clinton administration during its entire tenure (Gross 2001).

However, this is not to ignore the presence of some members of the Congress who argue that the Bush administration offers little guidance as to how to interpret the behavior of North Korean President Kim Jong-Il’s government (Katz 2003). Indeed, some legislators have gone as far as North Korea itself in order to find solution to the issue, and their actions show that some 
congressional leaders remain committed to diplomacy (Katz 2003). Moreover, the Bush administration's options in dealing with the nuclear crisis remain constrained and influenced by a variety of factors which include, but are not limited to, post-conflict Iraq and domestic US policies (Rowen 2003). Observers (Wit 2001) assert that Bush, in continuing the path of engagement, will allow the administration an easier time in building a domestic consensus for its approach than Clinton did. Maintaining a strong domestic consensus could also serve the administration well in coping with political pressures and other issues (Wit, 2001).

For more than ten years, the US domestic debate about how to deal with North Korea has boiled down to an argument between engagement and confrontation (Huntley 2003). The Clinton administration attempted to do two things simultaneously (National Intelligence Council Conference Report 2001). First, it wanted to deflect charges of appeasement from its domestic critics, who viewed food assistance as providing comfort to the enemy (Marshall 2003). Second, it wanted to promote diplomatic movement with North Korea. Unfortunately, neither ended up going so well. The Bush administration, on the other hand, has been bullying North Korea into complying with economic threats (Reiss 2004) and military actions (Kerr 2003).

However in the first quarter of 2003, Republican and Democratic legislators revealed severely different visions on how best to prevent North Korean nuclear proliferation. Republicans prioritized the bolstering of conventional military capabilities, while Democrats called for a more diplomatic solution, similar to the Clinton policy. The Republican leadership recommended that the US should consider using different types of nuclear weapons to threaten the DPRK, but the Democrats recommended that the US should reduce its reliance on the importance of nuclear weapons. Moreover, they pressured Bush a to develop a strategy stressing multilateral and bilateral negotiations, and including direct and immediate talks with North 
Korea, in order to strengthen international controls and nonproliferation norms. Table 11

compares the Clinton and Bush administrations policies towards the DPRK in terms of domestic constraints.

Table 11. Clinton, Bush and the US Congress

\begin{tabular}{|c|c|c|}
\hline Constraint & Clinton Administration & Bush Administration \\
\hline US Congress & $\begin{array}{l}\text { - Clinton had to deal with a } \\
\text { different, more independent, } \\
\text { centralized, partisan and } \\
\text { homogenous Congress } \\
\text { The Congress limited US } \\
\text { funds in dealing with the } \\
\text { North Korean nuclear threat } \\
\text { - Apparently, the Congress } \\
\text { was isolationist } \\
\text { The US congress were } \\
\text { divided between carrots and } \\
\text { sticks strategies, and bilateral } \\
\text { and multilateral negotiations }\end{array}$ & 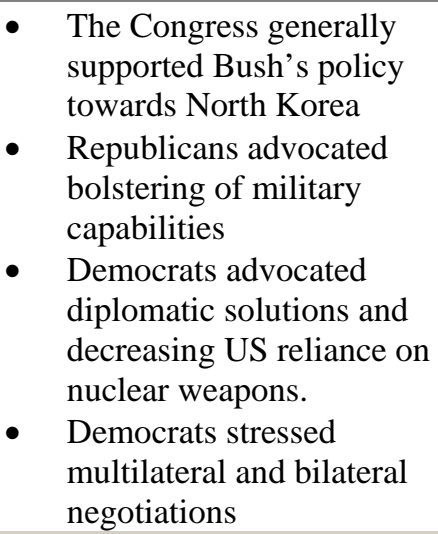 \\
\hline
\end{tabular}

Aside from the Congress, another domestic constraint faced by the Bush and Clinton

administrations in their policy implementation on the North Korea crisis was public opinion and American political culture. Clinton approached the public to rally and push Congress to support his programs.

Following the 9/11 attacks, foreign policy concerns again became the top priority of the American public. They began to see terrorism and nuclear proliferation as a direct and imminent threat to national security, and not just a foreign policy concern of the President. The general public in the Bush administration showed support for military involvement to curtail the DPRK. After the attack, Bush gained a 90\% approval rating, higher than any president had achieved before, and public opinion became geared towards supporting Bush and his War on Terror. One year after 9/11, his approval stood at 70\%. A November 2001 poll found that $81 \%$ of the polling population agreed that it would be best for the future of the country to take an active part in 
world affairs. Instead of calling for isolation from world affairs, which the American public felt prior 9/11, the public began patronizing engagement to the world. Indeed, this is in stark contrast to the public's approval ratings of Clinton's performance during his first term, which stood at a very low 40\%. And while the public's perception of his work on some foreign policy issues was positive, Clinton's overall foreign policy rating was a low 34\%. Similar to the public opinion during Bush's term, Americans in the Clinton administration were in favor of using US troops in intervening in foreign affairs. However, the Clinton administration was not keen on using force because of its responsibility to ensure the safety and protect the lives of every American. Thus, the central thrust of the Clinton strategy was diplomatic negotiations, in order to create cooperative security measures around the globe. However, a part of the American public in Clinton's administration was advocating for a sticks strategy, similar to the approach used by the Bush administration. See table 12 for the comparison of Clinton's and Bush's policies in relation to American public opinion.

Table 12. Clinton, Bush, and the American Public

\begin{tabular}{|c|c|c|}
\hline Constraint & Clinton Administration & Bush Administration \\
\hline Public Opinion & 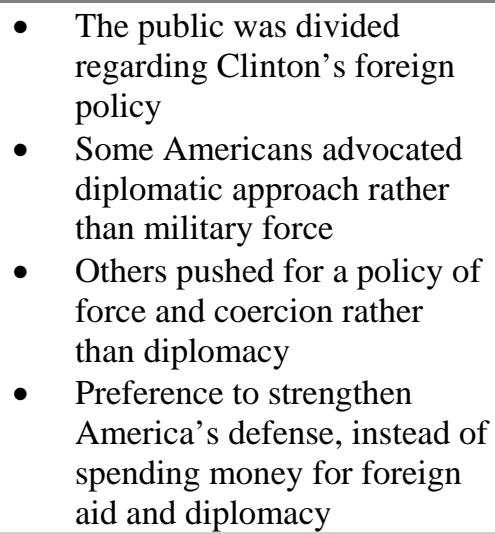 & $\begin{array}{l}\text { - } \\
\text { The American public } \\
\text { supported Bush's stick } \\
\text { strategy on North Korea } \\
\text { The public began to see } \\
\text { terrorism and nuclear } \\
\text { proliferation as a direct and } \\
\text { imminent threat } \\
\text { The general public agreed } \\
\text { that it would be best for the } \\
\text { future of the US to take an } \\
\text { active part in world affairs }\end{array}$ \\
\hline
\end{tabular}

Bureaucratic politics, which include the discrepancies in the actions of different agencies and institutions within the US government, have also provided significant policy constraints. The 
differences in the actions, particularly with the Defense Department and various intelligence agencies, have lead to inconsistency, which further aggravates the problems with the implementation process. Aside from the differences, the personality of Clinton and Bush can be cited as one factor in the failure to resolve the North Korean issue (Cha 2002; Cronin 1994). While Clinton can be criticized for his lack of leadership will, Bush's personality can also be said to be overly aggressive, as with his labeling North Korea as part of an axis of evil.

Bureaucratic problems had become evident from the outset of the Clinton administration. Instead of redefining ends and means, for most of its first year in office, the administration tried to avoid making tough choices. For instance, nuclear diplomacy was the subject of only three Principals' Committee meetings during 1993. Observations indicated a gaping void at the top of the bureaucracy (Berry 1995), and thus, with no one at the top in charge, American diplomatic strategy was one of drift, punctuated by spasms of zigzagging. State Department officials commented that the lack of regard to the field troops was reflective of a broader problem in the implementation strategy of Clinton’s policy, thus making the policy appear as a series of ad hoc improvisations without any organizing concept (Cronin 1994). Indeed, this was illustrated in the reluctance of then National Security Adviser Anthony Lake to construct a diplomatic deal that North Korea might find acceptable. Lake saw himself more as a policy broker than a policy entrepreneur in this case. Secretary of State Warren Christopher, who was acutely sensitive to hawkish pressures, also steered clear of seizing the diplomatic initiative (Sigal 1998).

The conflict during the beginning of the Clinton administration reflected the problem in the coordination among the implementing arm of the North Korean policy, a problem that continued throughout Clinton's second term. Predominantly, the reluctance of senior officials to take charge of dealing with North Korea, or to promote deal-making in public was perhaps the 
most telling evidence of the politics of the problem (Sigal 1998). The organizational interests, the primary motive in bureaucratic politics explanations, also predisposed most government agencies against a deal with North Korea (Sagan and Waltz 1995; Lake 1994). The armed services were a partial, though critically important, exception. For instance, the State Department has an interest in maintaining good relations by cooperating with other governments. Further, it also has an interest in negotiating with other governments. That interest leads it to insist on conducting negotiations on behalf of the United States. It does not necessarily incline the department to favor negotiations, especially when officials believe that talks will be fruitless, or worse, when they feel the other side will take advantage of talks to pursue its nuclear ambitions (Lake 1994).

To nonproliferation specialists within the State Department, and especially in Arms Control and Disarmament Agency (ACDA), preventing proliferation is seen as being synonymous with preserving and protecting the prerogatives of the IAEA. Nonproliferation specialists in the Pentagon have defined their interests differently. Rather than pursuing diplomatic solutions, they have been preoccupied with preventing North Korea from producing any more plutonium or diverting what it had to bomb making. The difference in outlook led them to take opposing stands at interagency meetings (Sagan and Waltz 1995; Sanger 1994).

In the meantime, there is still an existing and a well-recognized split in the Bush administration over its North Korea policy (Rowen 2003). The first policy faction, consisting of Vice-President Richard Cheney, Secretary of Defense Donald Rumsfeld and Undersecretary of State, John Bolton, advocate economic and political isolation, enforced compliance and eventual regime change as the preferred solution to the nuclear crisis. This group is strongly opposed to considering diplomatic negotiations before Pyongyang has fulfilled its obligations, as dictated under previous agreements. The second policy faction, led by Secretary of State Colin Powell 
and much of the State Department, supports the commencement of negotiations towards a comprehensive solution. This includes greater cooperation with both allies and partners in the region, as well as a greater commitment to reforming the North Korean regime through placing it firmly within the international community. Despite gaining strong support from experts and scholars of North Korea, the approach has been greatly weakened by the failure of diplomacy in the build-up to the Iraq conflict (Rowen 2003). Table 13 outlines the debate within the bureaucracy in relation to the US policies in the DPRK.

\section{Table 13. Clinton, Bush and the Bureaucracy}

\begin{tabular}{|c|c|c|}
\hline Constraint & Clinton Administration & Bush Administration \\
\hline Bureaucracy & 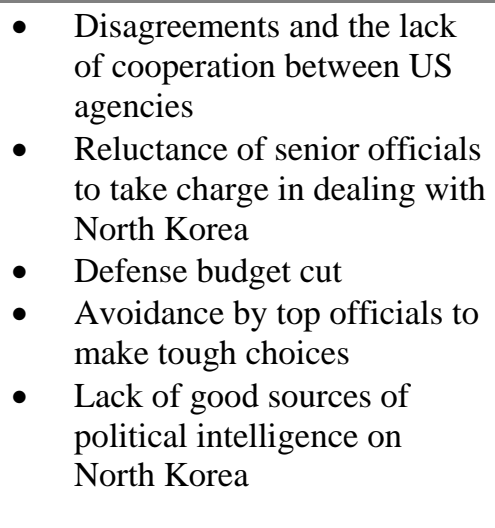 & 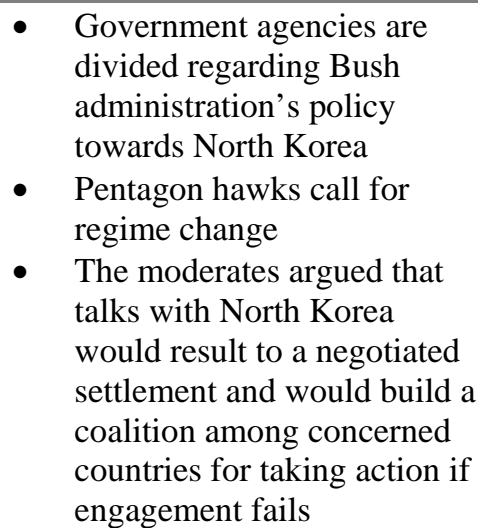 \\
\hline
\end{tabular}

\section{International Systemic Constraints}

With regard to their policies towards the North Korean nuclear program, the Bush and Clinton administrations have largely been faced with the same set of systemic constraints. These include the lack of cooperation, the failure of consensus-building between major powers including Japan, China, South Korea, and Russia, and, lastly, policy inconsistencies within the countries themselves. Moreover, the two US administrations were continually hounded by the difficulty of dealing with the Kim regime.

During his term, the Clinton administration made painstaking efforts to solicit viable 
support from its supposed partners, which included Japan, China, South Korea, and Russia. Clinton had been very confident that the task at hand would be easy, since it was universally acknowledged that a nuclear weapon constitutes a global threat. Nonetheless, each country has expressed its hesitation to fully cooperate in sanctioning North Korea economically. Japan, Russia, South Korea, and China agree that the situation calls for a peaceful negotiations as opposed to what US is offering at that time-economic sanctions for North Korea so that it would drop all of its nuclear activities (Korea Times June 15, 2002). At the time, each country was actively engaged in maintaining its good relationships with North Korea, and protecting their own vested interests. While Japan declined the American proposal, it shares the same concerns with the US over North Korea’s acquisition of nuclear capabilities. Japan is known as one of the strong advocates of nuclear disarmament, despite signing the US-Japan Security Treaty, which states that only US troops are admitted on Japanese soil, and stipulates that an attack on one force will be considered an attack on both, and that US would be prepared to use nuclear weapons.

Nonetheless, soon after the Second World War, Japan has been in constant effort to maintain peace with other countries. Hence, it has advocated several foreign policies which highly stress the necessity for continued peace and international stability. But during the Clinton administration, the Japanese Liberal Democratic Party started to contemplate about the effectiveness of the NPT. Worse, Japan’s Foreign Minister Kabun Muto harshly expressed its decision to develop its own nuclear weapons if necessary in July 1993 (Washington Post July, 1993; Japan Times Weekly, January 31-February 6, 1994: 5), a decision that is not impossible to materialize at the appropriate time. Arguably, this pronouncement only meant that the US had yet to gain the full confidence and cooperation of Japan, in its aim to resolve the North Korean 
nuclear threat. Given Japan's limited defensive capabilities, it appears that it cannot possibly launch its own nuclear weapons program. However, due to Japan’s lack of natural resources, the country has learned to depend largely on nuclear energy for its domestic needs, and presently, the country has already acquired fifty one atomic plants. Thus, Japan could indeed develop nuclear weapons if need be - they have all the raw materials, all the technology, and the necessary capital to produce a functional nuclear weapon (Japan-Nuclear Energy March 10, 2000). This further proved that indeed North Korea is a threat to the world's security. In short, other may intensify their nuclear programs for defense and security purposes.

Japan has been serious in its attempt to normalize relationship with North Korea (H. N. Kim 2004). This seriousness was materialized in September 2002 when Prime Minister Koizumi Junichiro took a bold initiative of visiting Pyongyang to hold a summit meeting with Kim JongIl. Although the first Japan-North Korea summit meeting did not result in an immediate normalization of diplomatic ties, partly because of the disputes over the abduction issue and partly because of the North Korean nuclear weapons program (H. N. Kim 2004), Koizumi continued his effort to normalize relationship with North Korea. Again, he took a second visit to Pyongyang to hold talks with Kim Jong-Il on May 22, 2004. This move by Koizumi has given rise to speculations that Japan is aiming to normalize diplomatic relations with the DPRK before his tenure as the Prime Minister expires in September 2006. According to H. N. Kim (2004), unless and until North Korea abandons its nuclear weapons program, it is unlikely that Japan will normalize diplomatic ties with North Korea.

Thus, the hope for US to pressure the DPRK to stop all its nuclear activities is still in the hands of Japan, since earlier it had expressed its support to Bush administration. Japan prioritized the North Korean nuclear threat, especially after the Taepo Dong missile launch over Japanese 
islands. For the Japanese, North Korean missile activities pose a direct threat for the country. From a diplomatic point of view, Japan could serve a vital role in the implementation of US policy on North Korea, as it is highly equipped with an excellent intelligence reporting capacity.

The Bush administration, like Clinton’s, had received China’s criticism over its plans to sanction North Korea economically (Ji 2001: 396). China declined support on the detachment of the US military presence. Moreover, China also adheres to its beliefs that the South will play a large part in the unification efforts, and thus it strongly promotes the development of excellent relationships on behalf of North Korea. Furthermore, China cannot just simply take apart its economic interests over North Korea, as North Korea serves as the China’s conduit for global superiority. As in the case with Clinton, China stands firm on its decision not to be held responsible for bringing about the collapse of North Korea, and a chaotic North Korea would be more than China could bear, as it would mean influx of war casualties from the country, and obligations to supply the country with foods, oil, and other goods. In addition, China fears that its support for the US would aggravate the political turmoil in the country, which falls beyond the best interests of Beijing. China's best interest lies in its goal to be the recognized regional hegemony in the East Asian region, which would be threatened if the US were to interfere. For China, it would be unsurpassed victory if North Korea would remain as a modestly potent nation, able to daunt an attack by the South and the US, yet sufficiently not armed so that its strength would limit China’s ability to forcefully negotiate with the country.

The Bush administration's policy over North Korea is lucidly inconsistent with the country’s Sunshine policy, which was advocated by former South Korean president Kim Dae Jung. This policy is largely fueled by his vision to improve ties between the North and South via extensive business collaborations and investing. Although there exist only a few conclusive 
findings about the impacts of the Sunshine Policy on the relationship between the two kin nations, analysts presuppose that South Korea will remain its vigor to develop peaceful ties with North Korea. South Korea sturdily upholds engagement as the best way of settling the issue, which it believes is the key instrument in persuading North Korea into the international community, and diminishing the menace posed by North Korea's nuclear programs. Moreover, South Korea fears that the hard-line American policy, and Bush's constant reference to North Korea as part of an axis of evil may annoy North Korea to the point of refusal to engage in any peaceful talks. As such, it is clear that both Clinton and Bush have failed to consider the national interests in designing their policy frameworks to address the North Korean nuclear programs. Although South Korean leaders accept that North Korea’s nuclear programs pose imminent threats for global security and stability, there is still the fact that South Korea is a kin country, and, as such, remains distant in approving economic sanctions and military attacks against North Korea. Thus, it constantly pursues the conduct of continued negotiations between North Korea and United States.

Similarly, Russia's ability to support both the Clinton and Bush administrations has been hindered by its own national interests. This was especially evident during Clinton’s administration. The hesitation is spurred by two things, the first being that Russia aspires to benefit economically from the Sunshine Policy sponsored by the South Korea, and second, that the country stands as the "main mover" behind North Korea’s decision to approve the plan to restore the inter-Korean railway, which will connect North Korea to the borderline of China. Russia is bound to be the primary recipient of the benefits of the proposed rail plan, since the railway is deemed indispensable in developing their Trans-Siberian railway, which would serve as the major channel for products between East Asia and Europe. Indeed, Russia shares the belief 
about the necessity for peaceful engagements to reconcile the nuclear issues between US and North Korea.

In summary, a major difficulty for both the Clinton and Bush administrations has been their inability to build that sufficient domestic and international confidence that is necessary to implement their initiatives. The refusal of US allies to support the Clinton administrations efforts to isolate North Korea was embarrassing for the Clinton administration, and raised serious questions about its ability to play a leadership role in international affairs. If, and only if, the Bush administration is willing to undertake the long and patient process of resolving these differences, will these countries consider adhering to its principles.

Table 14 shows the similarities and differences between the Clinton and Bush administration policies, in terms of the responses from South Korea, China, Japan and Russia.

Table 14. Clinton, Bush, and Concerned Countries

\begin{tabular}{|c|c|c|}
\hline Constraint & Clinton Administration & Bush Administration \\
\hline $\begin{array}{l}\text { Inconsistencies } \\
\text { between US and } \\
\text { other foreign } \\
\text { policies on North } \\
\text { Korea }\end{array}$ & $\begin{array}{l}\text { Clinton failed to get the full } \\
\text { confidence of South Korea, } \\
\text { Japan, China and Russia } \\
\text { South Korea called the } \\
\text { Clinton administration to } \\
\text { avoid unilateral concessions } \\
\text { to North Korea } \\
\text { - South Korea appeared to seek } \\
\text { a softer line } \\
\text { Japan was reluctant to go } \\
\text { along with the US threats to } \\
\text { impose economic sanctions } \\
\text { on North Korea } \\
\text { Japan strongly preferred an } \\
\text { approach emphasizing } \\
\text { diplomacy } \\
\text { China opposed the } \\
\text { introduction of harsh } \\
\text { measures against the DPRK } \\
\text { Russia preferred to prevent } \\
\text { any unilateral American } \\
\text { move }\end{array}$ & 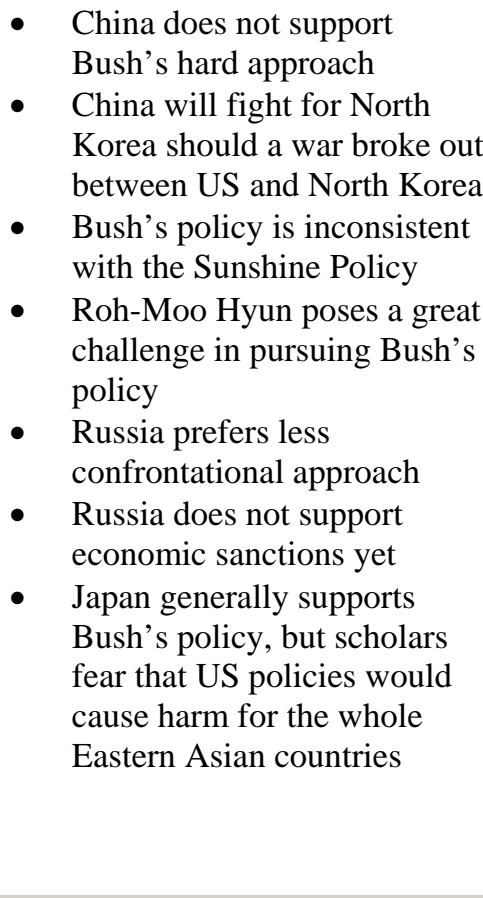 \\
\hline
\end{tabular}




\section{The Kim Regime}

One of the systemic constraints that challenged the Clinton administration, and has continued to challenge the Bush administration, is the firm stand of the Kim regime that the US is employing hard line policies, and that the US position in the nonproliferation regime is flawed, thus casting a doubt on the US intentions of resolving the North Korean nuclear threat. Differences in philosophies have constrained Clinton's and Bush's attempts to resolve the North Korean nuclear problem, and though the US has repeatedly made it clear that it is not aiming to attack the DPRK, the latter has begun insisting that their nuclear weapons development is now partially borne as a measure to counter any US aggression.

Under the Clinton administration, it was concluded that the regime was not about to collapse, and that Clinton would have to deal with Kim Jong-il. According to the Task Force on Terrorism and Unconventional Warfare (TFTUW), leadership in North Korea would not give up nuclear weapons, no matter how many agreements it entered into with the US. It was viewed that the nuclear weapons provided the ultimate insurance policy of the ruling elite in the DPRK (Wheeler, 2003), and that Kim Jong-il was a dictator struggling for regime survival by controlling the state security apparatus and occupying all key party, military and government leadership positions (International Crisis Group 2003: 2). Similarly, in the case of the Bush administration, there was mutual distrust between the US and the DPRK. This was heightened when the DPRK was provoked by Bush’s 2001 termination of negotiations over North Korea’s missile programs, his inclusion of North Korea in his axis of evil labeling, the administration's policy on preemption, and the US attack on Iraq, as evidence that the US poses a viable threat to the DPRK. In turn, the US has accused the DPRK of violating the 1992 agreement by pursuing an underground uranium-enrichment program. Moreover, the administration has contended that 
appeasing Kim Jong-Il’s demands would only encourage other would-be tyrants around the world to do what the DPRK is doing in terms of nuclear activities, and Washington has viewed North Korea’s April 2003 proposal as nothing but blackmail (Kerr 2003). The Bush administration has also continuously reiterated that it has no intention of attacking the DPRK. Despite this assurance, Pyongyang strongly believes that the US National Security Strategy and the 2002 Nuclear Posture Review indicate that the Bush administration is preparing to attack it. The table below outlines the constraints posed by the Kim regime to the Clinton and Bush administrations.

Table 15. Clinton, Bush, and the Kim Regime

\begin{tabular}{|l|l|l|}
\hline \multicolumn{1}{|c|}{ Constraint } & \multicolumn{1}{|c|}{ Clinton Administration } & \multicolumn{1}{|c|}{ Bush Administration } \\
\hline \hline Kim Regime & $\begin{array}{l}\text { US viewed North Korean } \\
\text { nuclear program as a } \\
\text { bargaining chip } \\
\text { North Korea viewed its } \\
\text { nuclear program as a means } \\
\text { to defend itself from foreign } \\
\text { adversaries } \\
\text { There is a mutual distrust } \\
\text { between the us and North } \\
\text { Korea }\end{array}$ & $\begin{array}{l}\text { The Kim regime views the } \\
\text { Bush administration policy } \\
\text { as flawed } \\
\text { North Korea has repeatedly } \\
\text { cited Bush's "hostile policy" } \\
\text { as justification to its nuclear } \\
\text { program } \\
\text { There is a mutual distrust } \\
\text { between the US and North } \\
\text { Korea }\end{array}$ \\
\hline
\end{tabular}

\section{Chapter Conclusion}

Bush and Clinton team shares the same sets of statecraft tools to confront foreign issues, positioning themselves as threats to the US national interests namely; military, economic, diplomatic, and informational. Another parallelism between the two leaders' approaches is their initial policy stance. Both chose to adopt a policy of indifference concerning North Korea's nuclear activities, as, for instance, the issue was not even included in their campaign initiatives. Concerns surfaced within several months of their proclamations. Nonetheless, both preliminary approaches had been aimed toward the development of diplomatic negotiations over the issue 
diplomacy being considered since it is the most logical step in promoting the political agenda of both nations and is one that is most cost-effective as opposed to other economic and military actions. Both however proved to be fruitless efforts.

Moreover, both Clinton and Bush relied on similar strategies, which included the utilization of sticks rather than carrots. Clinton launched an extensive military exercise in South Korea merely to pressure North Korea into following US instructions, and, like Bush, also used economic and trade sanctions as threats for North Korea to dismantle its nuclear programs. However, none of these worked in the US's favor, and, as in the case of Clinton administration, such feats threatened only to exaggerate things. The approach incited the same stubborn response from North Korea, and Clinton's economic and military threats only drove North Korea to the point of pulling itself away from the Nonproliferation Treaty. Bush, pursuing the same policies, faced the risks of exacerbating the nuclear threat of North Korea, and he received no luck with his own sticks. North Korea had merely turned a cold shoulder when Bush halted oil shipments to the country (Dao 2002; Shenon 2002).

Soon afterward, Bush, from the initial plan to offer North Korea nothing but sticks, started to lay a softer hand over the matter. After harshly criticizing the Clinton administration for its initiative to give away carrots to North Korea without getting anything in return, Bush adopted the same mechanism soon after its sticks did not spawn positive outcomes. Furthermore, Bush had foreseen the necessity to withdraw its firm hand against North Korea after it had generated only dwindling support among countries such as Japan, South Korea, China and Russia. Nonetheless, both administrations had nothing to brag with regards to lessening the intimidation caused by nuclear activities in North Korea, and indeed, North Korea continues to be a major threat to global security and stability. Moreover, both leaders, at least in 
the early part of their administrations, were determined to separate North Korea from the rest of the world, via sanctions and though an international effort. When this did not yield sustainable results, both bent to engage North Korea at various levels.

Though the goals of the two leaders may be well admirable, their means on advancing them have been rather foreboding. As analyzed, Bush and Clinton both exhibited several inconsistencies with regards to their policy approaches. Each consistently shifted from being aggressive to diplomatic in the ways they attempted to settle the issue. Contributing to such inconsistencies has been the presence of the conflicting policy stances of other powers. Both leaders had to sway back from their original policy preferences, which included isolating North Korea, because they failed to solicit general support from China and Russia. The politics inherent in US policy-making did not help, but only worsened the problem. Both administrations received arduous criticism, and endured extended debates over their policy preferences. Furthermore, both administrations have paid considerable attention to the significant roles of other countries, especially major Asian countries, in realizing their objectives (Hastedt 2003). This is largely because gaining their innumerable support provides the US likely success in implementing its economic sanctions and diplomatic talks with North Korea. Without the support of its major trading partners-Russia, Japan, China, and South Korea, it is hoped that North Korea will have no choice but to agree with US instructions. This is also the predicted consequence if North Korea proves unable to collect military assistance from at least one of these countries lest the military aggression will fail.

Another similarity has been the heedful effort of both administrations in soliciting worldwide support for their own foreign policies. Both the Clinton and Bush teams have received uneven approval and nasty criticisms over their way of handling their international 
affairs. Clinton's soft policy towards North Korea did not garner substantial appraisal from other countries, which was also the case with Bush's hard-line policies (Henirksen 2003). Both administrations had viewed North Korea, to some extent, in the same light. For them, North Korea’s nuclear capability placed high risks upon the country’s corporeal safety. Through its Taepo-Dong 1 missile, North Korea has made it clearly evident that it possesses the facility to aim its nuclear activities to virtually any target. Another reason is related to the raging aggressions in Asia that poses a threat to US economic stability. Hence, both administrations focused their policies towards eliminating the nuclear programs in the country, stopping the development and export of missile technology and hardware, and reconciling North Korea and South Korea (Henirksen 2003). Despite many similarities, overall approaches in settling the issue of North Korean crisis differ strikingly from each leader. Given the same dilemma under different circumstances, both Clinton and Bush fell into the parody that the choices that they had made were the most appealing ones to be implemented at that time. Nonetheless, closer scrutiny of situation would give rise to other much better options that could have been realized (Renshon 1995).

The aforementioned discussion reveals that while the two administrations possess several divergences in strategy, they also share several parallelisms. One remarkable similarity is their failure to consider North Korea’s circumstances (Hastedt 2003). For instance, both administrations had constantly assumed that economic sanctions could inevitably drive North Korea to its knees, and get it to dismantle its nuclear programs. But, much to the dismay of both parties, North Korea had other options open to it. Ultimately, there exists the same token that has brought for each administrative effort to take apart North Korea’s nuclear programs, which is their lack of consideration to North Korea’s capabilities as a nation. For instance, both leaders 
are accused of having unsatisfactory information capabilities. While Clinton is said to have relied heavily on guessing about the prime motivators behind the development of North Korea’s nuclear program (Renshon 1995), Bush’s analysis of North Korea’s capability to manage its resources to survive any forms of sanctions from the United States was also deemed faulty (Woodward 2003).

In formulating their policies, similarities between both administrations can be traced to the lucid interests of both Clinton and Bush. From this discussion, it is also a valid statement to conclude that perhaps Bush has been somewhat influenced by Clinton’s policy directions (Woodward 2003). The aspirations of the Clinton and the Bush administrations to resolve the North Korean nuclear threat is manifested in their policy goals. While they share the same policy goals, their strategies have differed significantly from the outset of each administration. However, it is my argument that the domestic and systemic constraints experienced by both administrations will ultimately lead to their adoption of the same policies. So far, the study has showed that due to the domestic and systemic pressures, the Bush administration is likely to adopt a policy similar to that of the Clinton administration, despite holding a hard line policy approach in which the following elements are already apparent: the use of multilateral-bilateral approach the use of multilateralism and bilateralism at the same time, the predominant use of carrots with the occasional employment of sanctions, the use of economic and diplomatic means as statecraft instruments. Second, the study has shown that the domestic constraints faced by both the Clinton and Bush administrations have consisted of the US Congress, the American Political Culture, including Public Opinion and Bureaucratic Politics, and the systemic constraints, consisting mainly of the difference in the policy goals and implementation strategies of South Korea, Japan, China and Russia. Finally, this study concludes that like the Clinton 
administration, the Bush administration is headed towards a stand-off with North Korea.

This dissertation strongly believes that the Bush administration will make major changes with regard to its policy on North Korea towards the end of its time in office. As discussed earlier, the generally strong support from the US domestic institutions as well as the American public has only strengthened Bush’s current policy objectives. Yet despite this, changes particularly a policy shift from a multilateral stick strategy to a bilateral carrot one will eventually be brought about by systemic pressures, coming primarily from major US allies such as South Korea, China, Japan and Russia, in addition to the political behavior of the Kim regime, while, the international regime will maintain its minor role in the Bush administration. Moreover, this study has shown that the major driver for the Bush administration's policy shift will be China, which consistently puts pressure on the Bush administration to hold one-on-one talks with the DPRK, which is something the Kim regime has been demanding since the administration came to power. In terms of shifting from economic punishment and intensified military activities, to economic and trade rewards and reduced military action, it has been known that South Korea, China, Japan and Russia all oppose the Bush administration's economic sanctions and its aggressive military posturing. These countries want diplomatic approaches to prevent war in the region, and, as such, Bush may opt to employ carrot strategy at the end of his administration. The table below summarizes the policy shift in the Clinton and Bush administrations. 
$\underline{\text { Table 16. Policy Shift }}$

\begin{tabular}{|c|c|c|c|c|}
\hline Variables & $\begin{array}{c}\text { Clinton } \\
\text { (Beginning) }\end{array}$ & Bush (Beginning) & Clinton (End) & $\begin{array}{c}\text { Bush } \\
\text { (Prediction) }\end{array}$ \\
\hline $\begin{array}{c}\text { Bilateralism and } \\
\text { Multilateralism }\end{array}$ & Bilateralism & Multilateralism & Bilateralism & $\begin{array}{c}\text { Bi- } \\
\text { multilateralism }\end{array}$ \\
\hline $\begin{array}{c}\text { Carrot and Stick } \\
\text { Approach }\end{array}$ & Carrots & Sticks & Carrots & Carrots \\
\hline $\begin{array}{c}\text { Inclusion and } \\
\text { exclusion of the } \\
\text { international } \\
\text { regime }\end{array}$ & Major & Minor & Minor & Minor \\
\hline
\end{tabular}




\section{CHAPTER VI: SUMMARY AND CONCLUSION}

This dissertation has attempted to compare and evaluate the conduct of US foreign policy towards North Korea, in order to address the North Korean nuclear threat under both the Clinton (1993-2000) and the Bush (2001-2004) administrations. The capabilities of these two administrations to carry out their preferred policies have been evaluated, in lieu with the systemic and domestic constraints that largely influence their policies. The systemic and domestic constraints faced by both administrations were deemed as the primary factors in their inclination towards the middle ground in dealing with North Korea, hence becoming similar towards the end of the Bush administration. This study sought to identify the domestic and systemic constraints in the US foreign policy towards North Korea’s nuclear proliferation, particularly with regard to the policy approach and implementation strategies used by the Clinton and the Bush administration in terms of multilateralism and bilateralism, carrots and sticks, and the use of economic, diplomatic and military means and the utilization of the international regime. Finally, three domestic factors were identified in this dissertation: (1) the US Congress, (2) the American public opinion, and (3) the bureaucracy, and the systemic factors identified included (1) the inconsistencies of foreign policies among the US, North Korea, South Korea, China, Japan, and Russia, and (2) the difficulty of dealing with the Kim regime. These domestic and systemic constraints in US policy toward North Korea provide the reason for the lack of a viable resolution to the North Korean crisis. As such, this study sought to identify the domestic and systemic constraints, so that the present and future US administrations can resolve the constraints before embarking on a policy approach.

This dissertation used the structured focused comparison in comparing the major areas evaluated for the study. The comparison was conducted through applying the same research questions to both cases, choosing the same variables to study such as the use of bilateralism or 
multilateralism, rewards or sanctions, or the inclusion/exclusion of the international regime, and in evaluating the same domestic US Congress, American political culture and public opinion and Bureaucratic politics and systemic the lack of coordination and difference in policy frameworks of South Korea, Japan, China and Russia, and the difficulty of negotiating with the Kim regime constraints. The two administrations under analysis were chosen for the study because of both the remarkable differences and interesting similarities in their foreign policies and approaches to the North Korean nuclear problem. The approach taken by the current administration rested on a realist perspective that rogue states, and those who engaged in proliferating weapons of mass destruction (WMD), must be dealt with in a firmer way such as with the use of military strategies to stop their operations. On the other hand, the Clinton administration favored the use of diplomatic approaches and negotiations, with a leaning towards economic sanctions in resolving Pyongyang's nuclear threat. Similarities between the two administrations include their initial isolationist stand regarding the North Korean problem.

Overall, this dissertation found that the policies of the Clinton and Bush administrations were largely affected by domestic and systemic constraints. This study also found that compared to the Clinton administration, the Bush administration is more likely to be affected by these factors. As such, this study expects that towards the end of Bush's term, a major shift in his policy towards the DPRK is likely to happen. In the end, we are expecting to see a Bush policy that is primarily directed towards the implementation of carrot and multi-bilateral approaches. 


\section{Summary Overview}

Chapter 1 has provided an overview of the North Korean issue, specifically the challenges to US Foreign Policy of North Korea’s nuclear proliferation, its recent withdrawal from the NPT and the characteristics of North Korean regime, its ideology, goals, strategies, and regional relations particularly in East Asia. It has also introduced the Clinton and Bush strategy in terms of their initial policy position, the domestic and systemic constraints they encountered and the prediction of the study.

Chapter 2 has provided a chronological discussion of the American/North Korean crisis from the 1990s to the present. A narrative of American Policy towards North Korea specifying exactly the actions the US has taken across Clinton and Bush administrations has been discussed. Moreover, this chapter has provided a historical narrative of the North Korean nuclear program and the US nuclear non-proliferation policy towards North Korea since the Clinton administration, described policy decision such as the Agreed Framework and the Six-Party Talks including all policy options considered in each administration.

In Chapter 3, the Clinton administration's policy on North Korea was examined extensively. This chapter has illustrated the overall logic of Clinton liberal internationalism foreign policy and the actions on the place of nuclear proliferation/North Korea and Clinton administration original/ opening posture towards North Korea shall be illustrated. In addition, this chapter has charted the implementation of Clinton policies in interaction with North Korea, other East Asian states including South Korea, China, Japan, and Russia, and US domestic and bureaucratic politics/decision making. Finally, his chapter has assessed the domestic and systemic constraints coping mechanism of the Clinton administration in terms of its policy approach and implementation strategy. 
Chapter 4 has evaluated the Bush administration's administration policy. This chapter has provided an overview of the overall logic of Bush conservative internationalism foreign policy and the place of nuclear proliferation/North Korea and Bush administration original/opening posture towards North Korea. Similar to the previous chapter, this chapter charted the implementation of Bush policies in interaction with North Korea, South Korea, China, Japan, and Russia. In addition, the fourth chapter has examined how the Bush administration coped and is coping with domestic factors that have affected his policy towards the resolution of the North Korean nuclear crisis.

In Chapter 5, the policies of the Clinton and Bush administrations were compared using the structured focus comparison. In particular, their policies were examined and compared on the grounds of bilateralism and multilateralism, carrot and stick strategies, and the inclusion and exclusion of the international regime. Furthermore, the pressures put forth by domestic and systemic factors on the two administrations and to what extent they have affected Clinton's and Bush's policies were compared. It was found that these constraints have largely shaped US policies towards North Korea.

\section{General Findings}

\section{Motivations for the North Korean Nuclear Program}

This study found that power, prestige and fear are the major motivations for developing nuclear weapons. Nuclear weapons provide a potent source of military and political power which is needed for regional dominance, and also equalize situations of military inferiority to a regional adversary, and may give significant power to sub-national groups struggling for independence, as well as to terrorist groups and nuclear blackmailers. Thus, status competition is a major motivation in the search for identity. In the North Korean case, nuclear weapons may be 
perceived as a way to avoid becoming marginalized, as the DPRK perceives itself as being overshadowed by its adversaries. Nuclear weapons can also mean technological prowess and elite status of the declared nuclear weapons states. While others, mostly developing nations, perceive a liNorth Korea between the declared possession of nuclear weapons and a permanent seat on the UN Security Council.

The rationale for the North Korean nuclear program is contested. On one hand, it is argued that it serves as a defense mechanism for the regime. On the other hand, it is argued that the nuclear build-up is for the accumulation of power, and, in turn, to threaten other countries. This study found that the most dominant motivators for North Korea in developing a nuclear program are concerned with economic survival and security defense. In the North Korean case, observers view that the country uses its nuclear program as a bargaining chip for economic assistance from other countries, especially the US. The reason for this is that the DPRK's economy has been in a continuous slump, and immediate regime survival largely depends upon its capacity to maintain a functioning economy. North Korea has experienced a major food crisis for more than a decade, and has failed to provide the basic necessities for existence, thus causing an increase in the black market economy, the spread of foreign currency, a surge in refugee flows across the Chinese border, widespread electricity shortages, and inadequate infrastructure undermining modernization attempts. However, despite North Korea’s falling economy, political instability has been remarkably avoided, in large part because South Korea, China, Japan, and Russia continue to provide Pyongyang economic assistance. This is also one of the reasons why North Korea is bargaining for economic rewards from the US, China, Japan and South Korea. To preserve the regime, North Korea must not only be able to maintain a functioning economy, but it must also be able to defend itself. As such, North Korea has attempted to justify 
its nuclear weapons program by claiming that its security is threatened by the increasing superiority of the US military. Specifically, North Korea claims that it needs nuclear weapons to: (1) provide a countervailing deterrent against US nuclear threats; (2) counter any future South Korean bomb; (3) deter SK’s overwhelming conventional military superiority; (4) compensate for the loss of Russia; and (5) ensure that North Korea is taken seriously as a major player in the region. Moreover, the DPRK perceives the nuclear deterrent as essential to its defense. However, this deterrence differs from the rationale of the US, which uses deterrence as a stabilizing factor to maintain a balance of power.

\section{US Policies on North Korea}

It has been shown in this dissertation that North Korea continues to be a headache in the nonproliferation regime, especially for the US. Since the 1950s, American presidents have tried to resolve the North Korean problems by employing different approach strategies. Despite these serious efforts, the North Korean regime has been giving the US, as well as other countries and the nonproliferation regime a hard time in dealing with the nuclear crisis. Throughout this study, the policies of the two recent US presidents toward the DPRK have been presented, and the grounds for comparison include bilateralism versus multilateralism, carrot versus stick, and inclusion and exclusion of the international regime. Furthermore, this dissertation presented three domestic constraints and two systemic constraints that significantly influenced the two administrations’ policies. The Clinton and Bush administration’ similarity lies on their initial policy positions during their term. That is, they both started with a policy of indifference towards North Korea. During his first presidential campaign, Clinton never made any mention of North Korea. The case was the same with Bush. However, subsequent events forced both the Clinton and Bush administration to address the North Korean threat. While Clinton was driven by the 
threat of nuclear capabilities of North Korea, Bush was and is using the threat of terrorism as his background for his actions in North Korea.

Their approaches to the North Korean, nuclear crisis have also been different. The Bush administration deviated from the Clinton administration's policy of containment and engagement from the outset, by employing a conservative internationalist approach instead of Clinton’s liberal internationalist approach; Bush demanded that North Korea destroy its nuclear weapons before engaging or entertaining any diplomatic means; Bush used a multilateral approach, used economic and military sanctions instead of bilateral diplomacy and the carrot strategy utilized by Clinton; Bush ended Clinton’s Agreed Framework Clinton and started the Six-Party Talks with China, South Korea, Japan, Russia, North Korea.

\section{Bilateralism and multilateralism}

Both the Bush and Clinton administrations eventually decided to use diplomacy conditional, in Bush’s case in addressing North Korea’s nuclear proliferation. However, Clinton preferred bilateral diplomacy while Bush adopted a more multilateral brand. North Korea, for its part, prefers bilateral negotiations in dealing with the US. When Clinton realized that sanctions would not work, he engaged the DPRK into high-level talks, which resulted in the creation of the Agreed Framework. Clinton’s bilateralism was comprised of high-level talks, ranging from nuclear program issues to economics, politics and military use. Through a bilateral approach, the Clinton administration moderated rogue states' behavior, while also aiming to contain aggression and achieve stability. On the other hand, the Bush administration has been an advocate of multilateralism, and has made it clear from the beginning that it intends to work with other countries, such as South Korea, China, Japan and Russia, and called for a Unified Front. The DPRK has been making attempts to engage the US in bilateral negotiations, but Bush has 
continued to insist on his more isolationist policy, and has refused to send negotiators to Pyongyang. Despite its belief that the crisis needs a bilateral solution from the US and the DPRK, North Korea eventually agreed to the Three-Party Talks with China and the US, followed by the Six-Party Talks with the US, South Korea, China, Japan, and Russia.

\section{Rewards and Sanctions}

Clinton's policy towards the DPRK operated under the philosophy of his engagement policy, which was reliant on economic rewards and bargaining through bilateral diplomacy. On the other hand, Bush deviated from this reward policy, and instead employed a policy geared towards punishment. Initially, Clinton and Bush chose to use sticks instead of carrots in dealing with the North Korean nuclear problem. However, when Clinton employed military coercion, the DPRK threatened to withdraw from the NPT. This threat made the Clinton administration realize that military aggression would only provoke the DPRK to do something drastic. Because of this, Clinton provided economic rewards to North Korea, and agreed not to impose any trade sanctions or undertake military actions against the country. Through the Agreed Framework, Clinton promised the funding for the construction of two water-light reactors and oil shipments in exchange with North Korea’s compliance to freeze their reactors and submit to IAEA inspections.

The Bush administration, as we have seen, criticized Clinton’s policy as being a show of weakness. Clinton was perceived to be giving away economic and trade rewards without getting anything in return, and the Bush administration believed that North Korea was just using its nuclear capabilities as bargaining chips against US to achieve stability and economic incentives. Thus, Bush had chosen to take a firmer stance toward North Korea by adopting a stick strategy. Evidence for this includes characterization of Kim Jong Il as a dictator, and a strong support for 
missile defense. However, this approach was hounded by oppositions from South Korea, China and Russia. This dissertation has shown that the Bush administration’s stick strategy, despite Bush’s promise of inflicting severe damage on the North Korean economy, has not been successful and has not caused the DPRK to change its political behavior. The study found that stick strategies would not be adversely affected by economic sanctions because Pyongyang has alternative trading partners, a command economy, and is not dependent on foreign trade. Moreover, the DPRK has prepared for economic isolation over many generations. These, together with international pressure and the lack of a productive response from North Korea, may have created a softening in the Bush administration's position towards the DPRK.

This study has suggested that the Clinton administration's policy seemed to give economic rewards to the DPRK for breaking agreements, thus giving the DPRK the idea that it could get what it wanted. With this apparent shortcoming in the Clinton administration's policy, it is easy to see why the Bush administration would want to break away from its predecessor's approach. In summary, this dissertation advocates the use of both carrots and sticks in resolving the North Korean nuclear problem, and views the use of carrots without sticks as being indicative of an appeasement policy. On the other hand, the employment of sticks without carrots is feared to cause severe economic destruction and the unnecessary loss of lives.

\section{The International Regimes}

From the outset, both the Clinton and the Bush administrations supported the international nonproliferation regime, and since then, the inclusion of the international regime has been a part of their strategies to gain the support of the international community. The Clinton administration maintained close ties with the IAEA in its military intelligence, and used the legitimacy of the NPT to muster cooperation from countries in order to demand that North Korea 
freeze its nuclear programs. Likewise, the international regime began as being one of the more significant measurement sources in enforcing the initial policies of the Bush administration, though its role has been greatly reduced when compared to its major role at the start of the Clinton administration.

However, the international regime has failed to live up to the US' expectations. In Clinton's term, North Korea threatened to withdraw from the NPT and no longer allowed the IAEA to inspect its nuclear facilities. Moreover, during the Clinton administration, the crimeand-punishment approach the IAEA attempted failed to suit the policy of engagement by the US. After Bush took office, North Korea formally withdrew from the NPT. During the Bush administration, the US was having difficulty to come up with an agreement with other memberstates in the NPT. Thus, for both administrations the role of the international regime was reduced in the latter part of their terms, as each began developing their own strategies.

\section{Domestic and Systemic Constraints}

Both Clinton and Bush's continuous shifts of policy and strategies have been a product of the domestic constraints each has encountered from the US Congress, American culture and public opinion and bureaucratic politics.

\section{The US Congress}

The US Congress is one of the foremost drivers in both the Clinton and Bush administrations' policies on the DPRK. In the former's case, the administration was having difficulty in gaining the support of the Congress, while on the other hand, the latter has been enjoying its general support. Clinton’s dilemma was largely due to the different, more independent, centralized, partisan and homogenous Congress. Unfortunately, the Clinton administration never seemed to win its way with Congress, which at the time was noted for its 
isolationism. The difficulty of getting Congressional support - from a Congress dominated by Republicans who constantly challenged his North Korea policy - ultimately pushed him to "go to the public”. The Clinton administration also had to deal with parochial, selfish political interests. Furthermore, the Clinton administration had to face a Congress dominated by Republicans who constantly challenged the administration’s policy on North Korea.

Unlike Clinton, Bush had only minor conflicts with the Congress. While the Clinton administration had to conduct extensive bargaining, especially with Congress to solicit support, the Bush administration faced very few domestic challenges. The Congress supported the Bush administration's choice of strategies in different foreign policy issues, allowed Bush to wage two wars on terrorism, one of them against Iraq, and supported the decision to withdraw from the 1972 ABM treaty. Unlike Clinton, Bush’s ability to carry the Congress with him has helped the administration reach a series of agreements with North Korea on security and economic issues.

\section{Public opinion}

As a result of the increasing focus global and foreign events brought about by September $11^{\text {th }}$, the American public showed support for Bush's drive against the proliferation of weapons of mass destruction. Americans began to see terrorism and nuclear proliferation as a direct and imminent threat. The general public began showing support for military involvement to curtail the DPRK's nuclear development, and indeed, after the attack the Bush administration posted a very high approval rating, 90\%, higher than any president had achieved before. While Bush was, and is enjoying the support of the American public for his North Korea policy, Clinton had to approach the public to rally and push Congress to support his programs. Unlike Bush, Clinton, in his first term, gained a very low public approval. And while the public's perception of his work on some foreign policy issues was positive, Clinton's overall foreign policy rating was a low, 
40\% according to the Program on International Policy Attitudes. However, similar to the public opinion in the Bush administration, Americans in the Clinton administration were also in favor of using US troops. But Clinton could not employ military coercion because of its concern and responsibility to ensure the safety of every American. This is amid the fact that some Americans called for a policy of force and aggression rather than diplomacy.

\section{South Korea, China, Japan, and Russia}

During his term, Clinton made painstaking efforts to solicit viable support from South Korea, China, Japan, and Russia. Each country has expressed its hesitation to fully cooperate in sanctioning North Korea economically, and have asserted that the North Korean nuclear problem needs peaceful negotiations. Moreover, they have been actively engaged in maintaining its good relationships with the DPRK due to some vested interests.

South Korea’s Sunshine Policy, with a vision to improve ties between the North and South, is seemingly irreconcilable with the Bush administration's policy. South Korea opposes Bush’s hard-line policy and his constant reference to North Korea as being part of an "axis of evil.” During both the Clinton and Bush administrations, South Korea has maintained that engagement is necessary to persuade the DPRK to join the international nonproliferation community and diminish the menace posed by its nuclear programs. South Korea disapproves economic sanctions and military attacks against North Korea, and constantly pursues the conduct of continued multilateral negotiations.

China's own policy towards the DPRK is also somewhat contradictory with Clinton's and Bush’s policy. The country has consistently opposed the two administrations' plans to impose economic and trade sanctions on the DPRK. Up to this day, China is pushing the development of improved relationships on behalf of the DPRK, though interest is perceived as becoming the 
recognized regional hegemony in Asia. This may partly explain why the country has opposed many actions by the Clinton and Bush administrations. Yet despite all these, China’s effective role as mediator between the US and the DPRK during the Bush administration has been notable. As with Clinton's term, China is persuading Bush to hold bilateral negotiations with the DPRK.

Along with South Korea and China, Russia, shares the same beliefs about the necessity for peaceful engagements to reconcile the nuclear issues between the US and North Korea. Also similar to South Korea and China, analysts observe that Russia is reluctant to support American policies, because it is trying to preserve its own interests. During the Clinton administration, Russia was seeking to benefit economically from the Sunshine Policy, and recently, Russia has supported North Korea’s decision to approve the plan to restore the inter-Korean railway, because it would be a beneficiary of the said plan since. The situation between the US and Russia worsened after the third round of the Talks. Nevertheless, Russia is still willing to participate in the fourth round of the multilateral process.

Another key player that has since affected US policies on the North Korean crisis is Japan. During the Clinton administration, Japan held inconsistent support for the US. At first, it advocated several foreign policies that highly stressed the necessity for continued peace and international stability, but it openly expressed that it would develop its own nuclear weapons if necessary. But overall, Japan supported the Clinton Administration's North Korea policy from 1993 to 2000. For example, Japan approved the US-Japan defense cooperation guidelines and cooperative research in the Theater Missile Defense system with the United States, for which Japan was accused by North Korea of using the missile issue - the reported test-firing of a ballistic missile over Japanese territory on August 31, 1998 - to create favorable public opinion for the revised cooperation guidelines and cooperative research (Park 2000). In fact, South Korea 
urged the Clinton Administration and the Japanese Government to take a softer stance toward North Korea (New York Times, August 17, 1998).

Among countries involved in the six-party talks, Japan has been the most supportive of the Bush administration's policies toward North Korea. Japan has proved itself as the best hope for the US, since earlier it had continuously expressed its support for the Bush administration. For one thing, unlike South Korea, Japan urged the Bush administration not to drop the DPRK from its terrorism list. Indeed, Japan has a vital role in US implementation of its policy on North Korea.

\section{The Kim Regime}

Another systemic constraint that has impeded US policies towards the DPRK is the difficulty of dealing with the Kim regime. Fundamental philosophical differences had constrained both Clinton and Bush’s attempts to resolve the North Korean nuclear problem. Although the US made it clear that it was not aiming to attack the DPRK, North Korea insisted that they were developing nuclear weapons as a deterrent against US aggression. Thus the North Korean nuclear problem will continue for a long time unless this major difference in thiNorth Koreaing is resolved.

\section{General Conclusions}

In terms of the motivations for US policy towards the North Korean nuclear crisis, this dissertation found that:

- Clinton and Bush initially chose to adopt a policy of indifference concerning North Korea's nuclear activities.

- While Clinton's motivation was nonproliferation, Bush used the 9/11 terrorist attacks as a cover for his foreign policy.

Regarding the domestic and systemic constraints faced by the Clinton and Bush 
administrations, this dissertation found that:

- $\quad$ The US Congress and the bureaucracy generally supported the Bush administration, but not Clinton's policy.

- There was a fragmented public opinion during the Clinton administration; during the Bush administration, the American public supported Bush's foreign policy.

- South Korea, China, Japan and Russia called for diplomacy, engagement, and soft line policy towards North Korea.

- North Korea demanded bilateral negotiations with the US.

Regarding the Clinton and Bush administrations' initial policy, this dissertation found

that:

- Clinton was consistent in his bilateral diplomacy. This was supported by concerned countries like South Korea, China, Japan and Russia. This also appeased the Kim regime.

- Bush, from the beginning, made it clear that he was employing multilateralism in dealing with the problem. Although his policy was favored domestically, major countries, most notably China, prefers bilateralism.

- Clinton initially relied on stick strategy but domestic and systemic pressures prompted him to employ carrots. This continued to the end of his term.

- Bush is firm on his position to impose economic and military sanctions. Although this action was favored domestically, major countries prefer soft line policy.

- Clinton initially considered the major role of the international regime. Bush initially considered the minor role of the international regime.

In terms of the policy shift towards North Korea in both the Clinton and Bush administrations, this dissertation found that:

- Domestic and systemic constraints largely shaped Clinton’s and Bush’s policies towards North Korea.

- Clinton carried on with his bilateral approach because of the support it gained from the international community.

- Bush’s multilateral approach will change to bilateralism operating in a multilateral setting due to systemic pressures.

- Clinton used carrot strategy when US allies denounced his aggressive policy. 
- Bush's policy is likely to shift from stick strategy to carrot strategy. This early, the Bush administration's policy has softened after the third round of the six-party talks.

- As with the Clinton administration, the Bush administration will continue operating its own policy with a minor help from the international regime.

This dissertation concludes that towards the end of the Bush administration, a policy somewhat similar to the Clinton administration's policy, except the employment of a multibilateral approach is very likely. This change will be largely affected more by systemic factors rather than domestic factors. 
References

“A Nuclear North Korea: The Choices Are Narrowing.” 1994. World Policy Journal, 11 (summer), 27-35.

Adkins, Tom. 2003. "What will George Bush do about North Korea?” http://www.opinionet.com/article.php?id=1840 (June 12, 2004).

Agreed Framework. 1994. Geneva, October 21.

Albright, David and Kevin O’Neill. eds. 2000. Solving the North Korean Nuclear Puzzle. Washington, D.C.: ISIS.

Albright, David, Frans Berkhout, and William Walker. 1997. Plutonium and Highly Enriched Uranium 1996: World Inventories, Capabilities and Policies. Oxfore: Oxford University Press.

Allison, Graham. 1969. “Conceptual Models and the Cuban Missile Crisis.” American Political Science Review, 63 (3), 689-718.

Almond, Gabriel. 1960. The American People and Foreign Policy. New York: Praeger.

Ambrosius, Lloyd E. 2003. "Rethinking Diplomatic and Strategic History." Reviews in American History, 31(4), 626-632.

American Bar Association. 1994. Standing Committee on Law and National Security, "Beyond COCOM--A Comparative Study of Export Controls: Germany, United Kingdom, France, Italy and Japan and the European Union Export Control Regulation," Task Force on Nonproliferation of Weapons of Mass Destruction, September.

Amini, Gitty Madeleine. 2002. Sanctions and Reinforcement in Strategic Relationships: Carrots and Sticks, Compellence and Deterrence. Dissertation Abstracts International, A: The Humanities and Social Sciences, 62, 8, Feb, 2878-A

Arms Control and Disarmament Agreements. 1990. Washington, DC: United States Arms Control and Disarmament Agency.

Aronson, Slomo. 1992. The politics and strategy of nuclear weapons in the Middle East: Opacity,theory, and reality, 1960-1991. Albany: State University of New York Press.

Atomic Archive. 2005. "A timeline on nuclear weapons development in North Korea.” http://www.atomicarchive.com/Reports/Northkorea/Timeline.shtml (August 1, 2005).

Axelrod, Robert and Robert Keohane, R. 1985. “Achieving Cooperation under Anarchy: Strategies and Institutions,” World Politics, 36(1), 226-254.

Bailey, Kathleen C. 1993. Strengthening nuclear nonproliferation. Boulder, CO: Westview. 
BBC News. 2004. “North Korea Renews Nuclear Demand.” http://news.bbc.co.uk/2/hi/asiapacific/3146297.stm (August 3, 2005).

BBC News. 2005. “Timeline: N Korea nuclear standoff.” http://news.bbc.co.uk/2/hi/asiapacific/2604437.stm (August 1, 2005).

Beal, Tim. 1998. “North Korea: From Confrontation to Communication.” New Zealand International Review, 6,14-18.

Beck, Peter M. 2004. “The Bush Administration’s Failed North Korea Policy.” from http://www.cankor.ligi.ubc.ca/issues/161.htm (May 30, 2005)

Behrens, Carl E. 2000. "Nuclear Nonproliferation Policy.” http://www.ncseonline.org/nle/crsreports/international/inter57.cfm?\&CFID=5129457\&CFTOKEN=89764094 (August 3, 2005).

Bennett, Andrew and Alexander George. 1997. "Research Design Tasks in Case Study Methods.” Paper presented at the MacArthur Foundation Workshop on Case Study Methods, Belfer Center for Science and International Affairs (BCSIA), Harvard University, October 17-19.

Berger, Sandy. n. d. “American Power: Hegemony, Isolationism or Engagement” http://www.cfr.org/pub3600/samuel_r_berger/american_power_hegemony_isolationism_ or_engagement.php (August 1, 2005).

Bermudez, Joseph S. 2001. The Armed Forces of North Korea. London: I.B. Tauris.

Berry, William E. 1995. US Air Force Academy Institute for National Security Studies. "North Korea's Nuclear Program: The Clinton Administration's Response.” INSS Occasional Paper 3. http://atlas.usafa.af.mil/inss/OCP/ocp3.pdf (May 29, 2005).

Bezlova, Antonaeta. 2003. "Politics-China: Beijing's influence over North Korea overstated, Global Information Network (New York), January 10, 1.

Bock, Nancy A. 2002. "War Powers Granted.” http://www.suffolkjournal.com/news/2002/pages/warpowers.htm (June 14, 2004).

Boese, Ward. (2003). Republicans, Democrats Square Off on Approaches to Proliferation. Arms Control Today. Arms Control Association. Available at www.armscontrol.org.

Bosworth, Stephen. 2000. The U.S. Ambassador to South Korea. Monthly Joongang, June, 54.

Bronfenbrenner, Urie. 1961. "The mirror-image in Soviet--American relations: A social psychologist's report.” Journal of Social Issues, 17, 45-56.

Brower, Kenneth. 1994. "North Korean Proliferation--The Threat to the New World Order." Jane’s Intelligence Review, Aug. 1, 376. 
Bunn, George. 1994. “The NPT and options for its extension in 1995.” The Nonproliferation Review, 1, 52-60.

Bunn, George. 2003. “The Nuclear Nonproliferation Treaty: History and Current Problems.” http://www.armscontrol.org/act/2003_12/Bunn.asp (June 4, 2004).

Burgin, E. 1992. “Congress, the War Powers Resolution, and the Invasion of Panama.” Polity, 25 (2), 217-242.

Busch, Nathan Edward. 2002. Assessing the Optimism-Pessimism Debate: Nuclear Proliferation, Nuclear Risks, and Theories of State Action. Dissertation Abstracts International, A: The Humanities and Social Sciences, 62, 11, May, 3927-A

Butler, Nicola. 2004. “One step Forward, Two steps Back: Six Party Talks on North Korea's Nuclear Programme.” http://www.acronym.org.uk/dd/dd78/78news04.htm (September 2, 2005).

Butler, S. et al. (1994). In Korea, Reality Bites. US News and World Rep., June 13, p. 30.

Byers, Michael. 1999. Custom, Power, and the Power of Rules: International Relations and Customary International Law. Cambridge: Cambridge University Press.

Carlson, Rich. 2003. The Crisis on North Korea. http://www.basicint.org/pubs/Notes/2003NorthKorea.htm (June 14, 2004).

Carnegie Endowment for International Peace. 2000. “Allies Do not See a Missile Threat.” http://www.carnegieendowment.org/publications/index.cfm?fa=view\&id=494 (May 29, 2005).

Cha, Victor D. 2002. “Korea’s Place in the Axis.” Foreign Affairs, 81(3), 79-92.

Cha, Victor D. 2004. “A Nuclear Fission: The North Korea Debate in Washington.” Harvard International Review, 25(4), 75.

Cha, Victor D. and David C. Kang. 2003. Nuclear North Korea: A Debate on Engagement Strategies, New York: Columbia University Press.

Chambers, Michael R. and Robert K. Goidel. 2004. "Beyond the Water's Edge: Public Opinion, Foreign Policy, and the Post-Cold War Presidency.” White House Studies, 4 (1), 31.

Policy, and the Future of American Democracy. New York: Oxford University Press.

Choi, Brent. 2003. “The Hostage Situation: Is It For Real?.” The Joong-ang Daily, April 29.

Chronology of U.S.-North Korean Nuclear and Missile Diplomacy. 2003. http://www.armscontrol.org/factsheets/dprkchron.asp (May 29, 2005). 
Chung, Chien-Peng. 2003. “Democratization in South Korea and Inter-Korean Relations.” Pacific Affairs, 76 (1), 9.

Chung, Ok-nim. 2001. “The New U.S. Administration’s Korea Policy and Its Impact on the Inter-Korean Relations.” East Asian Review, 13(1), 4.

CIA Report to the U.S. Congress on North Korea's Nuclear Weapons Potential. http://www.fas.org/nuke/guide/dprk/nuke/cia111902.html (June 12, 2004).

Conachy, James. 2002. “Bush’s ‘evil axis’ speech destabilises the Korean peninsula.” http://www.wsws.org/articles/2002/feb2002/kore-f15.shtml (September 2, 2005).

Conachy, James. 2004. "Standoff Continues over North Korea’s Nuclear Programs.” http://www.wsws.org/articles/2004/feb2004/nkor-f02.shtml (June 12, 2004).

Congressional Quarterly Weekly Report 49, no. 1 January 5, 1991): 7.

Congressional Quarterly Weekly Report 49, no. 2 January 12, 1991): 66.

Cook, Fay Lomax, Jeff Manza, and Benjamin I. Page. eds. 2002. Navigating Public Opinion: Polls,

Cossa, Ralph. 2001. “US-Korea: Summit Aftermath.” http://www.csis.org/pacfor/pac0111.htm (June 14, 2004).

Cronin, Richard.1994. “North Korea’s Nuclear Weapons Program: US Policy Options.” CRS Report for Congress, CRS94-470F

CRS Issue Brief 91141, North Korea's Nuclear Weapons Program

CRS Issue Brief 92056, Chinese Missile and Nuclear Proliferation: Issues for Congress

CRS Issue Brief 94054, Nuclear Arms Control and Nuclear Threat Reduction: Issues and Agenda.

CRS Report 95853, The U.S.-North Korea Agreed Framework to End North Korea's Nuclear Weapons Program

Cumings, Bruce. 2001. “Contesting US Hyperpower: Dangerous Dynamics.” Le Monde Diplomatique, May.

Daalder, Ivo H. and James M. Lindsay. 2003. "Nuclear Wal-Mart? Bush's Foreign Policy Disaster in North Korea.” The American Prospect, 8(14), 15.

Dao, James. 2002. "Bush Administration Halts Payments to Send Oil to North Korea.” New York Times 14 November 2002.

Dahl, Robert A. 1964. Congress and Foreign Policy. New York: Harcourt Brace and Company. 
Daschle, Thomas. 2003. "US Senate Democratic Resolution on Non-Proliferation Policy, March 5.” http://www.acronym.org.uk/docs/0303/doc06.htm (September 2, 2005).

De Young, Karen. 2002. “Bush Lays Down a Marker for 3 'Evil' States.” The Washington Post, January 30, A1.

Declaration on the Proliferation of Weapons of Mass Destruction. 2003. G-8 Summit, Evian France, June 3 http://www.sipri.org/contents/expcon/2003summit.html (August 2, 2005).

Destler, I.M. 1998. “Foreign Economic Policy Making under Bill Clinton.” In After the End: Making U.S. Foreign Policy in the Post-Cold War World, ed. J. M. Scott. Durham, NC: Duke University Press, 89-107.

Deutsch, John. 1992. “The new nuclear threat.” Foreign Affairs, 71, 120-134.

Dewar, Helen. 1994. “Clinton, Congress at Brink of Foreign Policy Dispute.” Washington Post, May 16, Al, A10.

Diehl, Jackson. 2002. “Rice Produces a Brilliant Synthesis.” The Washington Post. http://www.uni-muenster.de/PeaCon/global-texte/g-w/n/diehl-ricebrilliance.htm (June 14, 2004).

Dong-A Ilbo Daily. 2000. “KEDO to Review Light Water Reactor Project.” Dong-A Ilbo Daily, November 15.

Dong-A Ilbo Daily. 2003. “Bush: Progress Made in Settlement of NK.” Dong-A Ilbo Daily, April 15.

Downs, Chuck. 1999. Over the Line: North Korea's Negotiating Strategy. Washington: AEI.

Doyle, Michael W. and Ikenberry, G. John. eds. 1997. New Thinking in International Relations Theory. Boulder, Colo: Westview.

Eagleton, Thomas. 1974. War and Presidential Power. New York: Liveright.

East Asia Review. Autumn, 2002. www.imjinscout.com/American_Internationalism.html (June 12, 2004).

Eberstadt, Nicholas. (1996) “National Strategy in North and South Korea.” National Bureau of Asian Research Analysis 7 (5), 10, 12.

Eichensehr, Kristen. 2001. “Broken Promises.” Harvard International Review, 23(3), 11-12.

Elich, Gregory. 2003. “Targeting North Korea.” http://globalresearch.ca/articles/ELI212A.html (April 27, 2004).

Elliott, Kimberly Ann. 1997. “Will Economic Sanctions Work Against North Korea?.” In Peace and Security in Northeast Asia: The Nuclear Issue and the Korean Peninsula, ed. Y. W. Kihl and P. Hayes. New York: M.E. Sharpe. 
Erickson, Jim. 2003. "Odd Man Out: Six-country nuclear-arms talks leave North Korea more isolated than ever." Time Asia, September 8. Available at http://www.time.com/time/asia/magazine/article/0,13673,501030908-480339,00.html.

Ertman, Michael. 1993. “North Korean Arms Capabilities and Implications.” Nuclear, Chemical, and Ballistic Missiles, Korea and World Affairs, 17 (4), 605-626.

Faiola, Anthony and Edward Cody. 2004. "North Koreans Agree to Mid-Level Talks.” Washington Post Foreign Service, A14.

Falk, Richard and Anthony D’Amato. eds. 1980. "The treaty on the Non-Proliferation of Nuclear Weapons.” In Documents on International Law and World order. Minn: West Publications, 204-206.

Feffer, John. 2000a. Containment Lite: A Special Report on Russia and its Neighbors. http://www.fpif.org/progresp/volume3/v3n29_body.html\#containment (July 30, 2005).

Feffer, John. 2000b. Gunboat Globalization: The Intersection of Economics and Security in East Asia. Social Justice, 27 (4), 45-62.

Feffer, John. 2002. “Bush Policy Undermines Progress on Korean Peninsula.” Foreign Policy in Focus, 7 (2), 2-5.

Fein, Leonard.2003. Potent, But Not Omnipotent. http://www.forward.com/issues/2003/03.01.17/oped5.html (June 14, 2004).

Finnegan, Michael J. 1999. Constructing Cooperation: Toward Multilateral Security Cooperation in Northeast Asia. Asian Perspective 23 (1), 81-109.

Fisher, Richard. Jr. 1994. "North Korea's Nuclear Threat Challenges the World and Tests America's Resolve.” The Heritage Foundation, Asian Studies Center Backgrounder. No. 129 (February), 4-5.

French, Howard. 2003. “N. Korean Reaction on Iraq Is Subdued So Far.” The New York Times, April 2, A6.

Friedman, Benjamin. 2003. Nuclear Issues Fact Sheet: North Korea's Nuclear Weapons Program. Washington, DC: Center for Defense Information.

Galdi, T. W. and Shuey, R. D. (1988). CRS Report for Congress, U.S. Economic Sanctions Imposed against Specific Foreign Countries: 1979 to the Present, 88-612F, 109.

George W. Bush Administration Policy toward North Korea. 2004. http://www.nationmaster.com/encyclopedia/George-W.-Bush-administration policytoward-North-Korea (July 3, 2004). 
George, Alexander. L. 1979. "Case studies and theory development: The method of structured focused comparison.” In Diplomatic History: New Approaches, eds. P. G. Lauren. New York: Free Press, 42-68.

Gittings, John. 2002a. “N. Koreans offer America talks on nuclear fears.” The Guardian, October 22.

Gittings, John. 2002b. “Rumsfeld gets tough on North Korea.” The Guardian, December 24.

Global Security. 2004. “DPRK Economy.” http://www.globalsecurity.org/military/world/dprk/economy.htm (June 28, 2004).

Global Security. 2005. “Korea Crisis Countdown Timeline.” http://www.globalsecurity.org/military/ops/korea-timeline.htm (August 1, 2005).

Gordon, Michael. 2003. “A tale of two crises.” New York Times, 17 Feb. 2003

Gross, Donald. 2001. "North Korea's Misunderstanding of Bush Administration Policy.” http://www.csis.org/pacfor/pac0149.htm (June 14, 2004).

Haass, Richard N. 1995. "Military Intervention: A taxonomy of Challenges and Responses.” In The United States and the Use of Force in the Post-Cold War Era, ed. The Aspen Strategy Group. Queenstown, MD: The Aspen Institute, 1-18.

Hagan, Joe. 1993. Political Opposition and Foreign Policy in Comparative Perspective. Lynne Rienner.

Hagan, Joe. 2004. Opposition, Leaders and War. Mew York: Prentice Hall.

Hagan, J. and Margaret Herman. 2001. Leaders, Groups, and Coalitions: Understanding the People and Processes in Foreign Policy. New York: Blackwell Press.

Halberstam, David. 2001. Administration in War in a Time of Peace: Bush, Clinton and the Generals, New York: Scribner.

Han, Yong-Sup, and Norman D. Levin. 2002. Sunshine in Korea: the South Korean Debate over Policies toward North Korea. Santa Monica, CA: Rand.

Hastedt, Glenn P. 2003. American Foreign Policy Past Present and Future, 5th ed. Upper Saddle River: NJ.Prentice-Hall.

Hayes, Peter. 2003. "Bush's Bipolar Disorder and the Looming Failure of Multilateral Talks With North Korea.” http://www.armscontrol.org/act/2003_10/Hayes_10.asp (June 4 2004).

Held, David and Anthony G. McGrew. 1998. “The End of the Old Order?” Review of International Studies, 24 (5), 219-242. 
Heginbotham, Eric. 2004. "North Korea, South Korea and U.S. Relations.” http://discuss.washingtonpost.com/wp-srv/zforum/02/sp_world_heginbotham011403.htm (June 14, 2004).

Henirksen, Thomas. H. 1996. Clinton's Foreign Policy in Somalia, Bosnia, Haiti, and North Korea. Stanford: Stanford University Press.

Hibbs, Mark. 2003. “U.S. Confirms It Has Intelligence Pointing to DAE Planning Arms Tests.” NuclearFuel. April 14.

Hoagland, Jim. 2003. “Talk Plus Muscle on North Korea.” Washington Post, p. B07.

Huntley, Wade. L. 2003. "Strategic Insight: Countdown in Korea.” http://www.ccc.nps.navy.mil/rsepResources/si/may03/eastAsia.asp (June 24, 2004.

Hwang, Balbina. 2002. "Overcoming the Stalemate on the Korean Peninsula.” http://www.heritage.org/Research/AsiaandthePacific/HL750.cfm (June 12, 2004).

Hwang, Y.-S. and Kim, Y.-S. (2003). Differences between US and NK Lower Expectations for Beijing Nuke Talks. Dong-A Ilbo Daily, Aug. 28. http://english.donga.com (July 3, 2004).

Il-whan, Oh. 2002. "Exercising American Internationalism: U.S-North Korea Relations During the Bush Administration.” East Asian Review, 14 (3), 3-20 .

International Crisis Group. (2003). North Korea: A Phased Negotiation Strategy. Washington, D. C.: ICG Asia Report No. 61.

Jackson, Peter and Jennifer Siegel. 2005. "Intelligence and Statecraft the Use and Limits of Intelligence in International Society. Description.” http://www.greenwood.com/books/BookDetail.asp?dept_id=1\&sku=C7295\&imprintID=I 1 (May 29, 2005).

Jacobs, Jamie Elizabeth. 1997. “The Environment and Democratic Political Participation in Brazil: Attitudes and Awareness in Comparative Perspective.” Ministry of Foreign Relations, Brasilia, November 17-21.

Japan Times Weekly. Jan. 31-Feb.6, 1994: 5.

Japan-Nuclear Energy. 2000. “Japan - Nuclear Energy.” http://www.fas.org/news/japan/000310japan 1.html (January 28, 2004).

Jeffery, Simon. 2002a. “North Korea restarts Nuclear programme.” The Guardian, December 12.

Jeffery, Simon. 2002b. “Expelled UN inspectors leave N Korea.” The Guardian, December 31.

Jentleson, B.W. (1992). The Pretty Prudent Public: Post Post-Vietnam American 
Ji, Y. (August 2001) China and North Korea a fragile relationship of strategic convenience. Journal of Contemporary China, 10(28), 396.

Jones, C. (1993) Korea Prompts Japan to Review No-Nukes Policy. Christian Science Monitor, Aug. 11: 4.

Jones, G. and Marini, J. eds. (1988) The Imperial Congress: Crisis in the Separation of Powers. Washington, DC: Heritage Foundation and Claremont, CA: Claremont Institute.

Juster, Kenneth I. 2000. “The United States and Iraq: Perils of Engagement.” In Honey and Vinegar: Incentives, Sanctions, and Foreign Policy, eds. R. N. Haass and M. L. O’Sullivan. Washington: Brookings Institution, 51-69.

Karl, D.J. (2001) Lessons for Proliferation Scholarship in South Asia: The Buddha Smiles Again. Asian Survey., 41, 6, Nov-Dec, 1002-1022

Karp, A. (1996). Ballistic Missile Proliferation: The Politics and Technics. Oxford: Oxford University Press.

Katz, Jonathan M. (June 2003). Congress Divided on North Korea, Confused by Bush Policy. Available at http://www.armscontrol.org/act/2003_06/congress_june03.asp. Retrieved on 25 June 2004.

Kaufman, Burton I. 1999. The Korean Conflict. Westport, CT: Greenwood.

Kelleher, Catherine. M. 1994.” Soldiering On: U.S. Public Opinion on the Use of Force.” Brookings Review, 12(2), 26.

Kerr, Paul. January/February 2003. "North Korea Quits NPT, Says It Will Restart Nuclear Facilities.” http://www.armscontrol.org/act/2003_01-02/nkorea_janfeb03.asp (June 4, 2004).

Kerr, Paul. March 2003. "North Korea Restarts Reactor; IAEA Sends Resolution to UN.” http://www.armscontrol.org/act/2003_03/nkorea_mar03.asp (June 4, 2004).

Kerr, Paul. April 2003. “N. Korea’s Uranium Program Moving Ahead, Kelly Says.” http://www.armscontrol.org/act/2003_04/nkorea_apr03.asp (June 4, 2004).

Kerr, Paul. May 2003. "North Korea, U.S. Meet; Pyongyang Said to Claim Nukes.” http://www.armscontrol.org/act/2003_05/nkoreanews_may03.asp (June 4, 2004).

Kerr, Paul. June 2003. "North Korea Ups the Ante in Nuclear Standoff.” http://www.armscontrol.org/act/2003_06/nkorea_june03.asp (June 4, 2004).

Kerr, Paul. October 2003. "U.S. Shows More Flexibility in North Korea Talks.” http://www.armscontrol.org/act/2003_10/NorthKorea.asp (June 4, 2004). 
Kerr, Paul. September 2003. "Countries Meet to Discuss N Korean Nuclear Stand-off.” http://www.armscontrol.org/act/2003_09/Northkorea.asp (June 4, 2004).

Kerr, Paul. May 2004. “U.S., North Korea Jockey For China's Support as Working Group Nuclear Talks Approach.” http://www.armscontrol.org/act/2004_05/NK.asp (June 4, 2004).

Khalilzad, Z. Davis, P. and Shulsky, A. (1993) Stopping the North Korean Nuclear Program. RAND Issue Paper, Dec. p. 3.

Kim, Hong Nak. 1998. “Japan in North Korean Foreign Policy.” In The North Korean Foreign Relations in the Post-Cold War Era, ed. S. S. Kim. Hong Kong, New York: Oxford University Press.

Kim, Hong Nack. 2004. “The Koizumi Government’s Policy Toward North Korea.” Prepared for delivery at the 2004 Annual Conference of the International Conference on Korean Studies, Sheraton National Hotel, Arlington, Virginia, on August 6-8, 2004.

Kim, Ilpyong J. 1998. Two Koreas in Transition: Implications for U.S. Policy. Rockville, MD: In Depth Books.

Kim, Kyung-wong. 2001. Changes in Inter-Korean Relations: The Vicissitudes of Politics.” East Asian Review, 13(4), 9-20.

Kim, Sungwoo. 1996. "North Korea's Foreign Trade with the World between 1980 and 1994.” World Competition Law and Economic Review, 19 (4), 69-80.

Kim, T.-H. (2003). How to Resolve the North Korean Nuclear Question. Analysis of Major International Questions, 3-7.

Kim, Y.-S. and Song, D.-K. (2002). NK Resumes Operation of Nuclear Facilities. Dong-A Ilbo Daily, Dec. 28.

Kimball, Daryl. 2002. “U.S. Nuclear Policy: 'Negative Security Assurances.”’ http://www.armscontrol.org/factsheets/negsec.asp (September 2, 2005).

Kirillov, Andrey, Aleksey Morozov, and Vladimir Pavlov. 2004. Russia: Deputy FM Says Unrealistic to Demand DPRK Immediately Drop Nuclear Program. ITAR-TASS, in FBIS: DR, Feb. 26, 2004.

Klare, Michael T. 2000. “An Anachronistic Policy.” Harvard International Review, 22 (2), 4651.

Koch, Andrew. 1999. “North Korean Shift Eases Tensions.” Jane’s Defence Weekly, Sept. 29, p. 21. 
Koh, Byung-Chul. 2004. "Six-Party Talks: A Turning Point”.

http://ifes.kyungnam.ac.kr/ifes/ifes/admin/uploadfiles/ifes_forum/030916-koh.pdf (July 3, 2004).

Koppel, Andrea and King, John. 2002. CNN Washington Bureau.

http://www.antenna.nl/ amok/eurobom/publicaties/fandr/fandr20.pdf (September 1, 2005).

Koppel, Andrea and Elsie Labbot. 2001. “U.S. to Begin Talks with North Korea.” http://www.cnn.com/2001/US/06/12/korea.us.missiles/ (June 14, 2004).

Korea Herald. 2003a. “Trilateral Talks Open in Beijing.” Korea Herald, April 24.

Korea Herald. 2003b. “South Seeks Chair at Talks.” Korea Herald, April 23.

Korea Times. 2002. “Two Years after the Summit: A need for engagement.” Korea Times, June 15.

Korean Central News Agency. February 29, 2004. "DPRK Foreign Ministry Spokesman on Sixway Talks.”

http://www.nautilus.org/DPRKBriefingBook/multilateralTalks/sixpartytalks2.html (27 August 2005).

Kowert, Paul, Vendulka Kubálková, and Nicholas Onuf. eds. 1998. International Relations in a Constructed World. Armonk, NY: M. E. Sharpe.

Kristensen, Hans. 2002. “Preemptive posturing.” Bulletin of Atomic Scientists, 58(5), 54-59.

Kristoff, N. (2003). New York Times. Column March 10.

Kucia, Christine. 2003. "NPT Meeting Confronts New Nuclear Threats.” http://www.armscontrol.org/act/2003_06/npt_june03.asp (June 4, 2004).

Kull, Steven. 1997. “Americans Have Not Turned Isolationist.” http://www.policyattitudes.org/noisoloped.html (May 29, 2005).

Kurtz, Stanley. 2003. “The Other Imminent Danger.” http://www.nationalreview.com/kurtz/kurtz030303.asp (June 12, 2004).

Lake, Anthony. 1994. “Confront Backlash States.” Foreign Affairs, 73 (2), 46.

Lake, Anthony. 2000a. "From Containment to Enlargement.” In The Clinton Policy Reader: Presidential Speeches with Commentary, eds. A. Z. Rubinstein et al. Armonk, NY: M.E. Sharpe, 20-27.

Lake, Anthony. 2000b. “Liberal Internationalism: America and the Global Economy.” In The Clinton Policy Reader: Presidential Speeches with Commentary, eds. A. Z. Rubinstein et al. Armonk, NY: M.E. Sharpe, 8-14, esp. 12-13. 
LaMontagne, Steve. 2002. "Bush Policy Aims to Pull Plug on US-North Korea Talks http://www.clw.org/control/nkbush.html (June 14, 2004).

Laney, James T. and Jason T. Shaplen. 2003. “How to Deal With North Korea.” Foreign Affairs, 82 (2), 16-23.

Larson, Eric. V. 1996. Casualties and Consensus: The Historical Role of Casualties in Domestic Support for U.S. Military Operations. Santa Monica, CA: RAND Corporation.

Larson, Eric. V. 1999. "Review of Kull and Destler, Misreading the Public.” Public Opinion Quarterly 63 (4), 624-627.

Lea, Jim. 2001. “North Korea has yet to respond to Bush’s offer to resume talks.” http://ww2.pstripes.osd.mil/01/jul01/ed071201i.html (June 14, 2004).

Lee, E. Y.-J. 2002. "Legal Aspects of North Korea's Nuclear Crisis and Construction of Nuclear Weapon Free Zone on the Korean Peninsula.” http://www.ialana.org (August 3, 2005).

Lee, W. C. 2002. "Avery Goldstein. Deterrence and Security in the 21st Century: China, Britain, France, and the Enduring Legacy of Nuclear Revolution.” China Review International, $9(1), 119$.

Leventhal, Paul. L. 1992. Plugging the leaks in nuclear export controls: Why bother? Orbis, 36, 167-180.

Lew, Kwant-chul. 2004. “Don't Just Trust, Verify—Dismantling North Korea's Nuclear Program.” http://www.armscontrol.org/act/2004_05/Lew.asp (June 4, 2004).

Lian, Brad and Oneal, J. 1993. “Presidents, the Use of Force, and Public Opinion.” Journal of Conflict Resolution, 37 (3), 277-300.

Lindsay, James A. 2003. “Deference and Defiance: The Shifting Rhythms of ExecutiveLegislative Relations in Foreign Policy.” Presidential Studies Quarterly, 33 (3), 530-547.

Litman, Leah. 2003. Cleaning House: Dirty Bombs and the Nuclear Non-Proliferation Treaty. Harvard International Review, 25 (1), 32.

Litwak, Robert, S. 2000. Rogue States and U.S. Foreign Policy: Containment After the Cold War. Washington, D.C.: Woodrow Wilson Center.

Litwak, Robert S. and Mitchell Reiss. 1994. Nuclear Proliferation After the Cold War. Washington: Woodrow Wilson Center.

Liu, Ming. 2003. “China and the North Korean Crisis: Facing Test and Transition.” Pacific Affairs, 76 (3), 347-373.

Lukin, Alexander. 2003. "Russia Joins the US in Tackling North Korean Challenge.”YaleGlobal, June 2. Available at http://yaleglobal.yale.edu/article.print?id=1757. 
Mack, Andrew. 1993. “The Nuclear Crisis on the Korean Peninsula.” Asian Survey, 33 (4), 33959.

Mack, Andrew. 1994. “A Nuclear North Korea: The Choices Are Narrowing.” World Policy Journal, 11(2), 26-35

Mansourov, Alexandre. 1995. In Search of a New Identity: Revival of Traditional Politics and Modernisation in Post-Kim Il Sung North Korea. Canberra: Australian National University Press.

Marshall, Joshua Mica. 2003. Remaking the World: Bush and the NeoConservatives. http://www.foreignaffairs.org/20031101fareviewessay82614/joshua-micahmarshall/remaking-the-world-bush-and-the-neoconservatives.html (June 24, 2004).

Mazarr, Michael. J. 1997. North Korea and the Bomb: A Case Study in Nonproliferation. New York, NY: Macmillan Press.

McFaul, Michael. 2002. “The Fourth Wave of Democracy and Dictatorship: Noncooperative Transitions.” World Politics, 54(2), 212-244.

Mearsheimer, John J. (1990). Back to the Future: Instability in Europe After the Cold War. International Security, 15(1), 5-56

Mearsheimer, John J. (2001). The Tragedy of Great Power Politics. New York, NY: W. W. Norton \& Company.

Meernik, James. 1995. “Congress, the President, and the Commitment of the US Military." Legislative Studies Quarterly, 20 (3), 377-392.

Miller, Steven. 2003. “The Real Crisis: North Korea’s Nuclear Gambit.” Harvard International Review, 25 (2), 83-84.

Ministry of Foreign Affairs of the PRC. 2003. "Foreign Ministry Spokesperson's Press Conference on April 29, 2003.” www.fmprc.gov.cn/eng/47886.html (May 30, 2005).

Mulley, F. W. 1962. The Politics of Western Defense. New York: Praeger.

National Intelligence Council Conference Report. 2003. “North Korea’s Engagement Perspectives, Outlook, and Implications.” http://www.cia.gov/nic/confreports_northkorea.html (June 24, 2004).

Newcomb, Mark E. 1994. “Non-Proliferation, Self-Defense, and the Korean Crisis.” Vand, J. Transnat’l L., 27, 603, 629

NewsMax.Com. 2002. "House Votes to Back Bush on Iraq.” http://www.newsmax.com/archives/articles/2002/10/10/165026.shtml (June 14, 2004). 
Niksch, Larry A. 2001. "North Korea's Nuclear Weapons Program.” http://www.cnie.org/nle/crsreports/international/inter-80.pdf (July 3, 2004).

Niksch, Larry A. 2003. "North Korea’s Nuclear Weapons Program.” fromhttp://fas.org/spp/starwars/crs/IB91141.pdf (May 29, 2005).

Nishihara, Marcus. 2003. “Japan Needs To Protect Itself Against North Korea.” International Herald Tribune, March 4.

Noland, Marcus. 2000. "Avoiding the Apocalypse: The Future of the Two Koreas. Washington: Institute for International Economics.” aper presented to the Roh Government Transition Team, Seoul, Korea, February 24.

Noland, Marcus. 2001. "Between collapse and revival: a reinterpretation of the North Korean economy.” http://www.iie.com/papers/noland0201-2.htm (June 28, 2004).

Noland, Marcus. 2003. “Life in North Korea: Testimony on Life Inside North Korea.” http://www.iie.com/publications/papers/noland0603.htm (June 28, 2004).

North Korea's Clandestine Nuclear Weapons Program. 2002. Carnegie Endowment for International Peace.

http://www.ceip.org/files/projects/npp/resources/northkoreacrisis.htm (August 17, 2005).

North Korea's Nuclear Arsenal Motivation, Doctrine and Possible Employment. 1996. Coulsdon, Surrey: Jane's.

Nuclear Threat Initiative. 2004. "North Korea Profile: Nuclear Overview.” http://www.nti.org/e_research/profiles/NK/Nuclear/ (June 28, 2004).

Nye, Joseph S. Jr. 2002. The Paradox of American Power: Why the World's Only Super Power Can't Go It Alone. New York NY: Oxford University Press.

O’Hanlon, Michael and Mike Mochizuki. 2003. Crisis On The Korean Peninsula: How to Deal with a Nuclear North Korea. NY: McGraw-Hill.

O’Sullivan, Meghan. 2000. "Sanctioning 'Rogue States.'" Harvard International Review, 22 (2), 56-61.

Oberdorfer, Don. 1998. "Recounting of conversations between Hwang and Selig Harrison.” In The Two Koreas, ed. D. Oberdorfer. New York: Addison-Wesley.

Office of International Information Programs, US Department of State. February 19, 2003. "Powell Looks for Multilateral talks with North Korea." http://www.useu.be/Categories/GlobalAffairs/Feb1903PowellNKorea.html (27 August 2005). 
Office of International Information Programs, US Department of State. February 24, 2003. "Powell Calls for Multilateral Approach to North Korea." http://www.useu.be/Categories/GlobalAffairs/Feb2403PowellNKorea.html (27 August 2005).

Oh, Kongdan and Ralph Hassig. 2000. North Korea Through the Looking Glass. Washington, D.C.: Brookings.

Okazaki, Hisahiko. 2001. "Bush Favors Tried-and-True Power Politics.” http://www.glocomnet.or.jp/okazaki-inst/hokazakius.dymaye.html (June 24, 2004).

Olsen, E. 1996. The Major Powers of Northeast Asia: Seeking Peace and Security. New York: Lynne Rienner.

Paal, Douglas H. 2001. A Policy Agenda for Achieving Korean Reunification. In Korea's Future and the Great Powers, eds. N. Eberstadt and R. J. Ellings. Seattle: Univ. of Washington Press.

Park, Kyung-Ae. 2000. "North Korea's Defensive Power and U.S.-North Korea Relations.” Pacific Affairs, 73(4), 535.

Park, Han, S. 2000. "North Korean Perceptions of Self and Others: Implications for Policy Choices.” Pacific Affairs, 73 (4), 503-517.

Park, Han S. 2002. North Korea: The Politics of Unconventional Wisdom. Boulder, CO: Lynne Rienner.

Participants Comment on Second Round Six-Party Talks. 2004. http://houston.chinaconsulate.org/eng/sgxw/t70681.htm (August 3, 2005).

People’s Daily. 2003. “DPRK Willing to Give Up Nuclear Plans.” http://english.peopledaily.com.cn/other/archive.html (July 3, 2004).

Perry, John. 2001. "Bush Flips on North Korea Talks.” http://www.newsmax.com/archives/articles/2001/6/7/204953.shtml (June 14, 2004).

Pickett, Molly. 2004. "North Korean Nuclear Talks: Bush Administration Perpetuating the Stalemate.” http://64.177.207.201/pages/16_519.html (June 12, 2004_.

Pickett, Molly and Ryan Purnell. 2004. “Immediate Senate Action: Pass the IAEA Protocol.”. http://64.177.207.201/pages/16_483.html (June 14, 2004).

Pilat, Joseph F. 1994. “Responding to Proliferation: A Role for Nonlethal Defense.” In Nuclear Proliferation after the Cold War, eds. M. Reiss and R. S. Litwak. Washington, D.C.: Woodrow Wilson Center, 275-290.

Pires, Jeong. J. 1994. "North Korean Time Bomb: Can Sanctions Defuse It? A Review of International Economic Sanctions as an Option.” Ga. J. Int'l \& Comp. L., 24(2), 307. 
Pollack, Jonathan D. 2001. "The Bush Administration and Northeast Asia: In Search of a Strategy.” Journal of International Studies, 28 (1), 6.

Pomfret, John. 2003. “China Urges N. Korea Dialogue.” The Washington Post April 4, A16.

Powell, Bill. 2003. “Nuclear Blackmail.” Fortune, 147 (1), 71-74.

Power, Jonathan. 2003. “A Hawk on North Korea Wants Bush to be a Dove.” http://www.transnational.org/forum/power/2003/02.01_NorthKorea.html (June 25 2004).

Puckett, Robert. 1993. The United States and Northeast Asia. Chicago: Nelson-Hall.

Reiss, Matthew. 2004. "Making Enemies: Politics, Profit, and Bush's North Korea Policy.” http://www.inthesetimes.com/site/main/article/making_enemies/ (June 14, 2004).

Rennack, D. E. and Shuey, R. (1997). “CRS Report for Congress: Economic Sanctions to Achieve U.S. Foreign Policy Goals: Discussion and Guide to Current Law.” Congressional Research Service, October 20.

Renshon, Stanley A., ed. (1995). The Clinton Presidency: Campaigning, Governing, and the Psychology of Leadership. Boulder: Westview Press.

Reveley, W. Taylor. 1981. War Powers of the President and Congress. Charlottesville: University of Virginia Press.

Roy, Denny. 1996-1997. “North Korea As an Alienated State” Survival, 38 (4), 22-36.

Rowen, Henry S. 2003. Kim Jong Il Must Go. http://www.policyreview.org/oct03/rowen.html (May 30, 2005).

Rourke, Francis E. 1972. Bureaucracy and Foreign Policy. Baltimore: Johns Hopkins.

Rubinstein, Alvin Z. et al. eds. 2000. The Clinton Policy Reader: Presidential Speeches with Commentary. Armonk, NY: M.E. Sharpe.

Sagan, Scott and Kenneth Waltz. 1995. The Spread of Nuclear Weapons: A Debate. New York:W. W. Norton.

Sanger, David. 1993. “North Korea's Game Looks a Lot Like Nuclear Blackmail.” New York Times, Dec. 12. Sec. 4, 6.

Sanger, David. 1994. "Clinton Approves a Plan to Give Aid to North Koreans.” New York Times, October 19, 1.

Sanger, David. .1994. "South Korean Expects Atomic Backdown by North." New York Times, February 24, A8.

Saunders, Phillip C. 2003. “Assessing North Korea's Nuclear Intentions.” http://cns.miis.edu/research/korea/nucint.htm (July 30, 2005). 
Schafer, Mark. and Scott Crichlow. 2000. "Bill Clinton’s operational code: Assessing source material bias.” Political Psychology, 21, 559-571.

Schafer, Mark. and Scott Crichlow. 2002. “The Process-Outcome Connection in Foreign Policy Decision Making: A Quantitative Study Building on Groupthink.” International Studies Quarterly, 46, 45-68.

Scheinman, Lawrence. 1992. "Nuclear safeguards and non-proliferation in a changing world order.” Security Dialogue, 23, 37-50.

Scheinman, Lawrence. 2000. "Politics and Pragmatism: The Challenges for NPT 2000." http://www.armscontrol.org/act/2000_04/lsap00.asp (August 3, 2005).

Schlesinger, Arthur, Jr. 1973. The Imperial Presidency. Boston: Houghton Mifflin.

Scott, James M. 1998. After the End: Making U.S. Foreign Policy in the Post-Cold War World. Durham, NC: Duke University Press.

Seo, Soo-Min. 2003. “Six Nations, Six Agendas.” Korea Times, August 27, 3.

Shah, Nikhil. 2003. "North Korea And International Law.” http://www.swans.com/library/art9/nshah01.html\#4 (August 25, 2005).

Shaikh, Farzana. 2002. "Pakistan's Nuclear Bomb: Beyond the Non-Proliferation Regime.” International Affairs, 78 (1), 29-48.

Shenon, Philip. 2002. “White House Rejects North Korean Offer for Talks.” New York Times. 4 October

Sherman, Wendy. 2002. "Dealing with Dictators.” http://www2.gol.com/users/coynerhm/dealing_with_dictators.htm (June 12, 2004).

Shimbun, Asahi. 2000.”U.S. Experts Ask Japan to Accept Exercising Right of Collective SelfDefense.” October 12. Associated Press.

Shirk, Susan L. 1997. “Asia-Pacific Regional Security: Balance of Power or Concert of Powers?” In Regional Orders: Building Security in a New World, eds. D. A. Lake and P. M. Morgan. University Park, PA: Pennsylvania State University Press, 245-270.

Sigal, Leon. 1998. “Jimmy Carter Makes A Deal.” Bulletin of the Atomic Scientists, 54 (1), 4046.

Sigal, Leon V. 1998. Disarming Strangers: Nuclear Diplomacy with North Korea. Princeton: Princeton University Press.

Sigal, Leon. (1999). The Method to the Madness. Newsweek International, Sept. 13.

Sigal, Leon. 2000. "Negotiating an End to North Korea's Missile-Making.” Arms Control Today, 30 (5), 3-8. 
Sigal, Leon. (2002) North Korea Is No Iraq: Pyongyang's Negotiating Strategy. Published by Arms Control Association. http://www.armscontrol.org/act/2002_12/sigal_dec02.asp (June 4 2004).

Silverstein, Brett. 1989. "Enemy images: The psychology of U.S. attitudes and cognitions regarding the Soviet Union.” American Psychologist, 44, 903-913.

Sivard, Ruth. L. 1991. World military and social expenditures 1991 (14th ed.). Washington, DC: World Priorities.

Smith, Jeffrey R. 1994a. “South Korea Offers Gesture to North.” Washington Post, Apr. 16: A13.

Smith, Jeffrey R. 1994b. “South Korea Takes Softer Stand Than U.S. on the North.” Washington Post, Apr. 24: A22.

Smith, Michael E. 1998. "Congress, the President, and the Use of Military Force: Cooperation or Conflict in the Post-Cold War Era?” Presidential Studies Quarterly, 28 (1), 36-50.

Sokolski, Henry. 1995. “Curbing Proliferation's Legitimization.” Nonproliferation Review, Winter.

Sokolski, Henry. 2001. Best of Intentions: America's Campaign Against Strategic Weapons Proliferation. New York: Praeger.

Sokolski, Henry. 2002. "Contending With a Nuclear North Korea.” http://nautilus.org/fora/security/0228A_Sokolski.html (August 3, 2005).

Sorensen, Clark. 2003. The Bush Administration and North Korea's Nuclear Program. Washington: University of Washington Press.

Suh, Dae-Sook and Chae-Jin Lee. 1998. North Korea after Kim IL Sung. Boulder, CO: Lynne Rienner Publishers.

Tajfel, Henry and Turner, John. 1979. “An integrative theory of inter-group conflict.” In The social psychology of intergroup relations, eds. W. G. Austin and S. Worschel. Belmont, CA: Wadsworth, 33-47.

Takeda, Yoshinori. 2004. “Japan-DPRK Summit: No Breakthrough, But One Step Forward. Carnegie Moscow Center.” http://www.carnegie.ru/en/pubs/media/70727.htm (May 30, 2005).

Telenko, Trent. 2003. "North Korea: Clinton Knew...And 'Kicked the Can Anyway.”, http://www.windsofchange.net/archives/north_korea_clinton_knewand_kicked_the_can_ anyway-print.php (May 29, 2005).

Thakur, Ramesh. 1993. “The United Nations in a changing world.” Security Dialogue, 24, 7-20. 
The Aspen Strategy Group. 1995. The United States and the Use of Force in the Post-Cold War Era. Queenstown, MD: The Aspen Institute.

The Economist. 2003. “Only China Keeps Things Going.” www.economist.com/printedition/displayStory.cfm?Story_ID=1748577. (May 30, 2005).

The Guardian. 2002. "North Korea admits to nuclear weapons programme.” The Guardian, October 17.

The Ministry of Foreign Affairs of Japan. 2004. "Six-Party Talks on North Korean Issues.” http://www.mofa.go.jp/region/asia-paci/n_korea/6party/index.html (July 3, 2004).

The Pew Global Attitudes Project. 2003. “International Public Concern about North Korea, But growing anti-Americanism in South Korea.” http://yaleglobal.yale.edu/display.article?id=2300 (July 6, 2004).

The Washington Times. 2003. “North Korea’s Nukes: Taking a hard line against Pyongyang.” The Washington Times, December 11.

Tkacik, John J., Jr. (2002). China Must Pressure Pyongyang. Retrieved May 30, 2005 from www.heritage.org/Press/Commenrary/ed123102b.cfm.

Tkacik, John J., Jr. (2003). Getting China to Support a Denuclearized North Korea. Retrieved May 30, 2005 from http://www.heritage.org/Research/AsiaandthePacific/bg1678.cfm.

Tomchick, Maria. 2003. “North Korea’s War Like Noises (And What They Mean).” http://www.counterpunch.org/tomchick01132003.html (June 25, 2004).

Treaty on the Non-Proliferation of Nuclear Weapons, opened for signature July 1, 1968, art. II.

U.S. Department of Defense, Office of the Secretary of Defense. 1996. "Proliferation: Threat and Response,” April.

U.S. Department of State. "Bureau of Political Military Affairs.” 1995 Report to Congress Pursuant to Section 601 of the Nuclear Non-Proliferation Act of 1978 for the year ending December 31, 1995.

U.S. Department of State. 1996. “Background Notes: North Korea.” http://www.state.gov/www/ background_notes/north_korea_0696_bgn.html (May 31, 2005).

U.S. General Accounting Office. 1994. "Nuclear Nonproliferation: US, International Nuclear Materials Tracking Capabilities are Limited.” GAO/RCED/AIMD 95-5, December.

U.S. General Accounting Office. 1995. "Poor Management of Nuclear Materials Tracking System Makes Success Unlikely.” GAO/AIMD-95-165, August. 
U.S. National Commission on Terrorist Attacks upon the United States. 2004. "Overview of the Enemy.” http://www.9-11commission.gov/hearings/hearing12/staff_statement_15.pdf (September 2, 2005).

U.S. Senate Committee on Foreign Relations. April 20, 1999. “Current and Growing Missile Threats to the U.S.” http://www.globalsecurity.org/wmd/library/congress/1999_h/s106339-2.htm (August 25, 2005).

U.S. Senate Committee on Governmental Affairs. 1994. "Nuclear Nonproliferation Factbook.” S.Rept. 103-111, December 1994.

U.S. Senate Committee on Governmental Affairs. 1995. “Global Proliferation of Weapons of Mass Destruction." Hearings before the Permanent Subcommittee on Investigations. S. Hrg. 104-422, Part I, Oct. 31 and Nov. 1, 1995.

Warrick, Jo. 2002. “Hunting a Deadly Soviet Legacy,” Washington Post, November 11, A01.

Washington Post. July 29, 1993: A18.

Watts, Jonathan. 2000. “Nobel prize goes to Seoul's Mandela.” The Guardian, October 14.

Weinberger, Caspar. W. 1999. “Rewarding North Korea.” Forbres, October 11, 42.

Weiss, Kenneth G. 1998. Crossroads: Nonproliferation, South Asia, and Global Stability. Livermore, California: Center for Global Security Research, Lawrence Livermore National Laboratory.

Wessels, M. G. 1995. "Social-Psychological Determinants of Nuclear Proliferation: a DualProcess Analysis.” Peace and Conflict, 1(1), 48-65.

Wheeler, Scott L. 2003. “Clinton Ignored Kim Jong-il's Nukes.” http://www.insightmag.com/main.cfm?include=detail\&storyid=342934 (July 3, 2004).

Wit, Joel (March 2001). Policy Brief \#74: The United States and North Korea. Available at http://www.brookings.edu/dybdocroot/comm/policybriefs/pb074/pb74.htm. Retrieved on 24 June 2004.

Wittkopf, Eugene R. 1990. Faces of Internationalism: Public Opinion and American Foreign Policy. Durham, NC: Duke University Press.

Wolfsthal, Jon Brook. 1993. Nuclear-Weapon-Free Zones: Coming of Age? Arms Control Today, 3 (2), 6-9.

Woodward, Bob. 2003. Bush at War, London: Pocket Books

Wormuth, Francis and Edwin Firmage. 1989. To Chain the Dog of War. The War Power of Congress in History and Law. Chicago: University of Illinois. 
Yi, Chang-hui. 2002. Chuch'e Oriented Opinion on the Realm of Circulation of the Means of Production in Socialist Societies. In P'yongyang Kyungje Yun'gu, Feb. 10, no. 1, pp. 2224,28

Young-Hui, Yi. 1993. "Nambook hwahae-wa koonchookui sin sidae-reul yeolcha” (Open the new era of North-South reconciliation and arms reduction), Wolgan Mahl (Seoul), Oct., 58-63.

Zaks, Dmitry. 2002. Russia defends North Korea ahead of Bush visit. Agence France Presse, May 20.

Zarocostas, John. 2003. "N. Korea offers to give up nukes.” http://www.washtimes.com/world/20031113-110713-6969r.htm (September 2, 2005).

Zogby, James. 1994. The Search for Foreign Policy. Washington Watch, August 1.

Zyuzin, Aleksandr and Alexei Morozov. 2004. Russia Calls for Package Solution to N. Korea Issue. ITAR-TASS, in FBIS:DR, Feb. 23, 2004. 